\title{
Kompakt kettős rendszerek poszt-newtoni fejlődése
}

\author{
Doktori értekezés
}

\section{Mikóczi Balázs}

MTA KFKI RMKI Elméleti Főosztály

Témavezető:

Dr. Gergely Árpád László

RMKI Témavezetö:

Dr. Forgács Péter

Fizika Doktori Iskola

Szegedi Tudományegyetem TTIK

Elméleti és Kísérleti Fizikai Tanszék

Szeged, 2010 


\section{Tartalomjegyzék}

1. Jelölések, konvenciók

2. Bevezetés

3. Gravitációs hullámok [10

3.1. A gyengetér közelítés . . . . . . . . . . . . . . . . . . . . س

3.2. Kompakt források leírása . . . . . . . . . . . . . . . . प5

3.3. Kepleri pálya gravitációs sugárzása . . . . . . . . . . . . . . ए8

3.4. A gravitációs hullámok mérése . . . . . . . . . . . . . . . . ए2

4. Poszt-newtoni formalizmus [27

4.1. Mozgásegyenletek származtatása a metrikából $(1 \mathrm{PN})$. . . . . . . . . . एप.

4.2. Mozgásegyenletek származtatása a dinamikai-egyenletből . . . . . . . . . ए एل

4.3. Forgás a mozgásegyenletekben . . . . . . . . . . . . . . . . . B:3

4.4. A spin-pálya kölcsönhatás . . . . . . . . . . . . . . . . . . 37

4.5. A testek forgása kvantumelméletböl . . . . . . . . . . . . . . . . 40

4.6. Spinprecessziós egyenletek . . . . . . . . . . . . . . . U D

5. Kettösök radiális mozgása 45

5.1. Lineáris járulékok a kepleri pályákhoz . . . . . . . . . . . . . . 46

5.2. Radiális egyenlet megoldása . . . . . . . . . . . . . . . . 5 5]

5.3. SSC invariancia . . . . . . . . . . . . . . . . . 53

5.4. Kepler-egyenlet . . . . . . . . . . . . . . . . . . . 56

5.5. Körpálya határeset . . . . . . . . . . . . . . . . 58

5.5.1. Kepleri körpálya . . . . . . . . . . . . . . . . . 58

5.5.2. Perturbált körpálya . . . . . . . . . . . . . . . . . . Б60

5.5.3. Kvázikörpálya . . . . . . . . . . . . . . . . 67

6. Az általánosan perturbált radiális mozgás

6.1. A módszer általánosítása . . . . . . . . . . . . . . . . 65

6.2. Az $n \geq 0$ eset . . . . . . . . . . . . . . . . Б6

6.3. Az $n<0$ eset . . . . . . . . . . . . . . . . . . 68

6.4. Alkalmazás kettös rendszerekre . . . . . . . . . . . . . . . . . . 面

6.4.1. Általános Brumberg erö . . . . . . . . . . . . . . . . प0

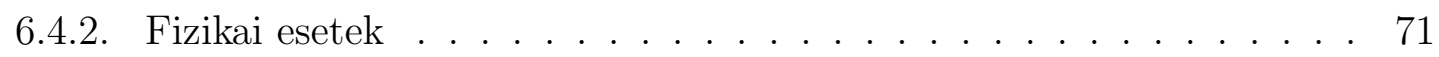


7. Kettősök szögmozgása 73

7.1. Pálya-impulzusmomentum származtatása . . . . . . . . . . . . [73

7.2. Euler-szögek . . . . . . . . . . . . . . . . . . . . . . . . . . पr4

7.3. Pályainklináció . . . . . . . . . . . . . . . . . . 76

7.4. Euler-szögek szekuláris fejlődése . . . . . . . . . . . . . . . . . . . 777

8. Pályafejlödés a gravitációs sugárzás által 799

8.1. Energiaveszteség . . . . . . . . . . . . . . . . . [79

8.2. Pályafrekvencia-fejlődés . . . . . . . . . . . . . . . . 8

8.3. Keringések száma a befelé spirálozási korszakban . . . . . . . . . . . 833

9. Pályafejlődés magasrendü korrekciói 85

9.1. PN rendek becslése . . . . . . . . . . . . . . . . . . 85

9.2. A gravitációs hullámok $3.5 \mathrm{PN}$ rendig . . . . . . . . . . . . . . . . . 86

9.3. A vezetőrendű spinprecesszióból származó járulék . . . . . . . . . . . . . 88

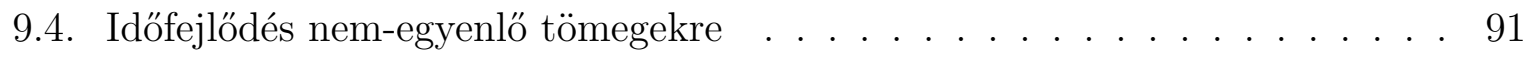

9.5. Keringések száma a spirálozási korszakban spinek jelenlétében . . . . . . . 92

Összefoglalás

$\begin{array}{ll}\text { Summary } & 98\end{array}$

Publikációs lista

Köszönetnyilvánítás [103

Appendix $\quad$ 104

B függelék

C függelék

Irodalomjegyzék 


\section{Jelölések, konvenciók}

A latin betűk $(a, b)$ a téridő indexeket $(0,1,2,3)$, a görög betűk $(\alpha, \beta)$ a térindexeket $(1,2,3)$ jelölik a dolgozatban. A metrika $\left(g_{a b}\right)$ szignatúrája: $(-,+,+,+)$. Egy tetszőleges $x^{a}$ koordináta szerinti parciális deriváltját az irodalomban használt (kovariáns és kontravariáns) $\partial_{a}=\partial / \partial x^{a}$ és $\partial^{a}=\partial / \partial x_{a}$ egyszerüsítésekkel rövidítem. A Christoffelszimbólumok előállítása a $g_{a b}$ metrikából

$$
\Gamma_{a b}^{c}=\frac{g^{c d}}{2}\left(\partial_{a} g_{b d}+\partial_{b} g_{a d}-\partial_{d} g_{a b}\right)
$$

A Riemann-tenzor definíciója

$$
R_{b c d}^{a}=\nabla_{d} \Gamma_{b c}^{a}-\nabla_{b} \Gamma_{d c}^{a}+\Gamma_{d e}^{a} \Gamma_{b c}^{e}-\Gamma_{b e}^{a} \Gamma_{c d}^{e}
$$

ahol $\nabla_{a}$ a kovariáns deriválás, mely egy tetszőleges $V^{b}$ vektorra a következőképpen hat: $\nabla_{a} V^{b}=\partial_{a} V^{b}+\Gamma_{e a}^{b} V^{e}$. További definíciók: $R_{a b}=R_{a c b}^{d} g_{d e} g^{c e}$ a Ricci-tenzor; $R=R_{a b} g^{a b}$ a Ricci-skalár és a $G_{a b}=R_{a b}-R g_{a b} / 2$ az Einstein-tenzor.

A $D / D \tau$ ún. geodetikus menti derivált definíciója egy tetszőleges $T_{. . b}^{a}$ vegyeskomponensü tenzorra

$$
\frac{D T_{. . b}^{a}}{D \tau}=\frac{d T_{. . b}^{a}}{d \tau}+\Gamma_{i j}^{a} u^{i} T_{. . b}^{a}+\ldots-\Gamma_{b i}^{j} u^{i} T_{. . j}^{a}
$$

ahol $u^{i}=d x^{i} / d \tau$ a négyessebesség ( $d / d \tau$ a görbe $\tau$ paramétere szerinti deriválást jelenti). Használom a tenzorok szimmetrikus és antiszimmetrikus részének jelölését, amelyek egy tetszőleges másodrendü $T_{a b}$ tenzorra, $T_{(a b)}=\left(T_{a b}+T_{b a}\right) / 2$ és $T_{[a b]}=\left(T_{a b}-T_{b a}\right) / 2$.

A globális Lorentz-transzformációja egy $x^{a}$ koordinátának $x^{a}=\Lambda^{a}{ }_{b} x^{b}$, ahol

$$
\Lambda_{b}^{a}=\frac{\partial x^{a}}{\partial x^{b}}=\left(\begin{array}{llll}
\gamma & \beta \gamma & 0 & 0 \\
-\beta \gamma & \gamma & 0 & 0 \\
0 & 0 & 1 & 0 \\
0 & 0 & 0 & 1
\end{array}\right)
$$

és $\beta=v / c, \gamma=\left(1-\beta^{2}\right)^{-1 / 2}$ a klasszikus elektrodinamikában használt jelölések.

Pauli-mátrixokra a standard $S L(2, \mathbb{C})$ reprezentációt használom

$$
\sigma^{(1)}=\left(\begin{array}{ll}
0 & 1 \\
1 & 0
\end{array}\right), \quad \sigma^{(2)}=\left(\begin{array}{ll}
0 & -i \\
i & 0
\end{array}\right), \quad \sigma^{(3)}=\left(\begin{array}{ll}
1 & 0 \\
0 & -1
\end{array}\right) .
$$

A naptömeget $M_{\odot}$-el jelölöm, melynek értéke $1.98892 \times 10^{30} \mathrm{~kg}$, illetve asztrofizikai példákban a távolságot kiloparszekben adom meg, $1 \mathrm{kpc}=3.086 \times 10^{19} \mathrm{~m}$. 


\section{Bevezetés}

Az általános relativitáselmélet közel 100 éves napjainkban. A gravitáció ezen klasszikusnak mondható elmélete jelenleg is egy intenzíven tanulmányozott területe a fizikának. Manapság rengeteg új megközelítése létezik Einstein eredeti gondolatának, mely jóslatainak igazolására a mai korszerű kísérleti berendezésekkel egyre több lehetőség adódik.

Gyenge gravitációs térben (a mi naprendszerünk tekinthető ilyen rendszernek) linearizálható az általános relativitáselmélet, vagyis a téridő felírható egy sík háttérmetrika (Minkowski) és egy lineáris perturbáció $\left(h_{a b}\right)$ összegére. Ezáltal az Einsteinegyenletekből hullámegyenlet származtatható, melyek a ,lineáris” gravitációs hullámok létezéséről adnak tanúbizonyságot. A gravitációs hullámok tulajdonképpen a téridőben fénysebességgel terjedő ,apró kis zavarok", melyek létét már Einstein 1916-ban megjósolta. 1918-ban, pedig meghatározta szintén a linearizált egyenletekből a gravitációs sugárzást leíró ún. kvadrupól-formulá-t [T], mellyel kiszámolható volt, hogy a gravitációs hullám igen ,kicsiny effektus”, formálisan az $\mathcal{O}\left(1 / c^{5}\right)$ rendnél jelentkezik.

$\mathrm{Az}$ általános relativitáselmélet nemlinearitása miatt, nehezen választható szét a téridő és a gravitációs hullám által okozott görbület. Ezért felmerült a kérdés, hogy léteznek-e egyáltalán ilyen hullámok a nemlineáris elméletben is. 1937-ben Einstein kétségbe vonta a gravitációs hullámok létezését [2]. A történet szerint, Einstein és Rosen által írt „Do Gravitational Waves Exist ?” címü kéziratukat a Physical Review folyóirat elutasította és csak a Journal of the Franklin Institute-ben jelent meg kevésbé provokatív címmel (,,On Gravitaional

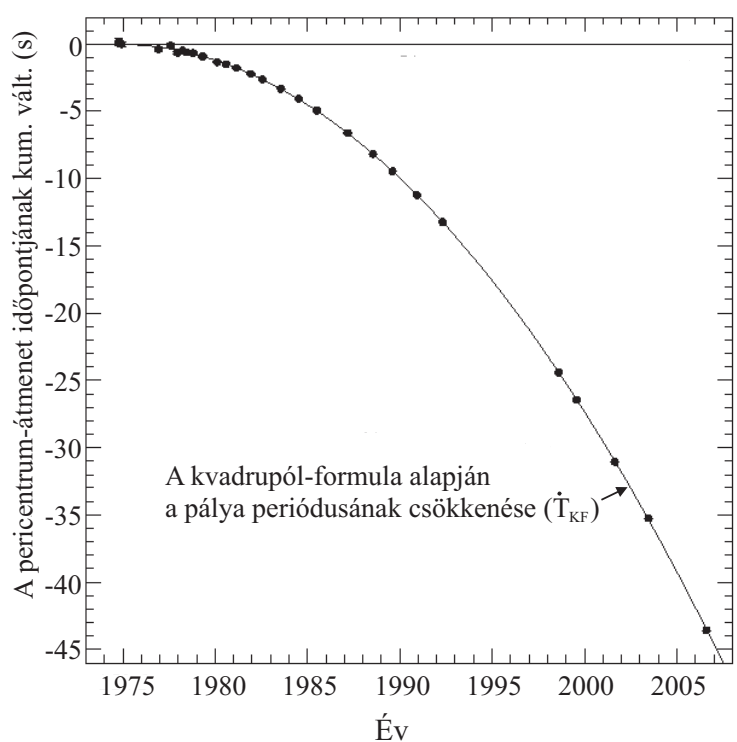

1. ábra. A Hulse és Taylor által felfedezett B1913+16 kettős pulzár periódusidejének csökkenése $\left(\dot{T}_{k o r} / \dot{T}_{K F}=1.0013 \pm 0.0021\right.$, ahol $\dot{T}_{k o r}=\dot{T}_{m e ́ r t}-$ $\dot{T}_{n a p}$ és $\dot{T}_{n a p}$ a naprendszer és a kettős pulzár közti relatív gyorsulásokból származó korrekció).

A gravitációs hullámok közvetett bizonyítékát 1974-ben Hulse és Taylor által felfedezett B1913+16 kettős pulzár csökkenő pálya periódusideje $(\dot{T})$ adta [3,4]. Ez a tőlünk 7.1kpc távolságra lévő két neutroncsillagból álló nagy excentricitású ( $e=0.617)$ rendszer, melynek pálya periódusideje 7.75h. A kvadrupól-formula alapján a 
periódusidő csökkenésére Wagoner a $\dot{T}_{K F} \sim-3 \times 10^{-12}$ értéket kapta 1975-ben [5], melyet a pulzár pontosabb pályaparamétereivel számolva a $\dot{T}_{K F}=(-2.40242 \pm 0.00002) \times 10^{-12}$ kapható [6]. A legújabb megfigyelések a $\dot{T}_{m e ́ r t ~}=-2.4184 \times 10^{-12}$ értéket adták, amely $(0.13 \pm 0.21)$ \%-ig egyezett a kvadrupól-formulából kapott eredménnyel (四. ábra) ${ }^{\boxplus}$. Hulse és Taylor 1993-ban a B1913+16 kettős pulzár felfedezéséért Nobel-díjat kaptak.

Az asztrofizikai objektumok által keltett gravitációs hullámok hullámhossza általában sokkal kisebb, mint a téridőből kapható görbület nagysága. Így az $R$ (Ricci-skalár) görbület felbontható a téridő háttérmetrikájára és egy gravitációs hullám által okozott görbületre. Ez a módszer tulajdonképpen a kvantummechanikában használt WKBközelítéssel ${ }^{\llbracket}$ analóg, mellyel a gravitációs hullámok mérésének elve megalapozható.

A gravitációs hullámok közvetlen kimutatása kísérletileg nagy kihívást jelent a XXI. századi fizikának, ugyanis a hullámok amplitúdója kb. $10^{-21}-10^{-22}$, amely mérhetetlenül kicsinek tűnik. Azonban mégis van lehetőség észlelésükre, ugyanis a hullámokat a téridőben lévő testek egymáshoz viszonyított gyorsulásával lehet kimutatni. Ezek a viszonylagos gyorsulások a Riemann-tenzorral mérhetők az Einstein-egyenletekből levezethető geodetikus deviációegyenlet alapján.

A detektálás alapja, hogy a detektor rendszeréhez rögzítenek egy saját vonatkoztatási rendszert, melyben a relatív elmozdulásokat tudják mérni. Mivel ez a rendszer nem inerciális, ,érezni” fogja a benne tanulmányozott részecskék newtoni gyorsulását. A gravitációs hullám nem más, mint a részecskéken keltett gyorsulás, melynek nagysága arányos a részecskék elmozdulásával. Vagyis a távolságkülönbség mérése alapján megkaphatók a gravitációs hullámok polarizációs állapotai, amelyek a Riemann tenzor független komponenseit jelentik. A linearizált vákuum egyenletekben 2 független polarizációs állapot van, a ,,+" és ,, ×" transzverzális állapotok. Nevüket onnan kapták, hogy a hullámfront síkjában a deformációs erővonalak + illetve, $45^{\circ}$-ban elforgatott $\times$ ,,alakúak" (『. ábra T2× és T2+ állapotai).

A jövőben mérhető gravitációs hullámok egy új asztrofizika kialakulását eredményezhetik, melyet nagy érdeklődéssel várnak az égbolt elektromágneses sugárzását kiaknázó csillagászok is. Korábban rezonátor típusú detektorokat alkalmaztak, azonban ezek hátránya, hogy szűk frekvencia tartományban tudtak mérni és érzékenységük sem volt megfelelő. Jelenleg a Michelson interferométer elven müködő gravitációs hullámdetektor a legalkalmasabb a mérésekhez. A leghosszabb karhosszúsággal $(4 \mathrm{~km})$ rendelkező interferométer az Amerikai Egyesült Államokban Hanford és Livingston

\footnotetext{
${ }^{1}$ Később Eddington kijavított egy 2-es faktort Einstein számolásában. Az idő folyamán többféle precízebb számolásokat végeztek a kvadrupól-formulára, de végeredményként mindig ugyanazt kapták, mind az elmélet, mind a mérések tekintetében.

${ }^{2}$ Wentzel, Kramers és Brillouin vezette be 1926-ben amely egy félklasszikus közelítése a kvantummechanikának.
} 
közelében található két LIGO (Laser Interferometer Gravitational-Wave Observatory) [7] detektor. Olaszországban, Cascina környékén található a Virgo (nevét a Virgo halmazról kapta) [8], mely $3 \mathrm{~km}$ hosszú karokkal rendelkezik. A LIGO és Virgo detektorok érzékenysége $10^{-21}-10^{-22}$. Léteznek kisebb interferométerek is, ezek a Németországban lévő GEO (German-British Gravitational Wave Detector) [9] és Japánban fellelhető TAMA300 (300m Laser Interferometer Gravitational Wave Antenna) [10], melyek 600m illetve 300m karhosszúságúak.

2018 után tervezik a világürbe telepíteni kívánt detektort, a LISA-t (Laser Interferometric Space Antenna) [1]] földkövető pályára állítani, amelynek ürszondái egy $5 \times 10^{6} \mathrm{~km}$ oldalhosszúságú szabályos háromszög csúcsaiban helyezkednének el.

Jelenleg már a harmadik generációs detektor, az Einstein teleszkóp (ET) tervezésénél tartanak, amely egy földalatti $10 \mathrm{~km}$ oldalhosszúságú a LISA-hoz hasonló szabályos háromszög alakú detektor lesz. Becslések szerint az érzékenysége elérheti a $10^{-24}$-et és esély van arra is, hogy a nemlinearitásból adódó gravitációs hullámokat is mérni fogja. A gravitációs hullámok mérésére alkalmas módszer még a PTA (Pulsar Timing Array), amely több pulzár pálya periódusidejének hosszú éveken át tartó méréséből határozhatja meg a gravitációs hullámokat, melyet Estabrook és Wahlquist vetett fel 1975-ben [12].

A gravitációs hullámok egyik legfontosabb forrásai a kompakt kettösök. Ezek olyan egymás körül keringő asztrofizikai objektumok, melyek nagy tömegsürüséggel rendelkeznek, vagyis fizikai méretük a Schwarzschild-sugár $\left(r_{S}=2 G m / c^{2}\right)$ közelében van. Ilyenek főként a fekete lyukak és a neutroncsillagok, illetve egyes szerzők a fehér törpéket is ide sorolják.

A kompakt kettősök a kvadrupól-formula alapján energiát és pályaimpulzusmomentumot veszítenek, melyet a gravitációs hullámok szállítanak el, melynek eredményeképpen csökken a pálya fél nagytengelye (mely ekvivalens a $T$ pálya periódusidejével) és excentricitása [13, 14]. Ezáltal a kettős befelé spirálozó mozgást végez, amely miatt, gyakran körpálya határátmenetben vizsgálják.

A kettősök klasszikus mozgását az általános relativitáselméletben a poszt-newtoni (továbbiakban PN) formalizmus segítségével adjuk meg. Einstein, Infeld és Hoffmann 1938-ban vezette be az általános relativitáselméletnek a gyenge gravitációs térre és a testek lassú mozgására $(v \ll c)$ érvényes közelítését a mozgásegyenletek leírására [15]. A közelítés az poszt-newtoni paraméter $\varepsilon=G m / r c^{2} \simeq v^{2} / c^{2}$ szerinti sorfejtése a metrikának, amelyet Infeld és Plebański tökéletesített a későbbiekben [16]. Erre példaként említhető a perihélium elfordulás, mint relativisztikus effektus $\mathcal{O}\left(1 / c^{2}\right)$, amely rendjét tekinte 1 PN járulék a kepleri mozgáshoz képest. Mivel a kettős rendszernek a komponensei a gravitációs sugárzás által befelé spirálozó pálya miatt közelebb kerülnek egymáshoz, ezért a mozgás leírásához magas PN-i rend szükséges. Jelenleg 3.5 PN rendig ismertek a 
mozgásegyenletek (a $0.5 \mathrm{PN}$ formálisan $\mathcal{O}(1 / c)$ rendü).

A PN-i mozgásegyenletek szétcsatolhatóak radiális és szögmozgásra (szögmozgás alatt a pálya gömbi polárszögekkel, vagy az Euler-szögekkel megadott fejlődési egyenleteit értem). A radiális rész megoldására a Damour és Deruelle által kidolgozott kváziparaméterezést használják [17,18], mely 3 PN rendig ismert [19].

A kompakt testeknek a saját tömegükön kívül további fizikai jellemzői vannak, az ún. véges méret-ből származó járulékai, ilyen a forgás (továbbiakban spin) [20], a tömeg kvadrupól-momentum [2T], és a forgó neutroncsillagra (pulzár) jellemző mágneses dipólmomentum [22], melyeket az irodalomban nem szoktak figyelembe venni. $\mathrm{Az}$ általános relativitáselméletből Mathisson [2:3] és Papapetrou [24] a forgó próbatest nemgeodetikus mozgásegyenleteit származtatták. Ezen egyenletek megoldása nem lehetséges, ugyanis a spinek bevezetésével bizonyos szabadsági fokok rögzítetlenül maradnak. Ehhez szükséges az ún. SSC (Spin Supplementary Condition) mértékválasztás rögzítése, amellyel a differenciálegyenlet-rendszer zárttá tehető. Az SSC mértékeknek 3-féle választása terjedt el, ezek az SSC I [25-27], az SSC II [28, 229] és az SSC III [30].

A spin a PN rendek szerint legkorábban 1.5 PN rendben a spin-pálya kölcsönhatásban (SO), 2 PN rendben a spin-spin (SS) kölcsönhatásban jelenik meg. Formálisan a SO és SS lineáris perturbáció (arányos $\varepsilon$-nal, vagyis 1 PN rendü), azonban a spin általában még $0.5 \mathrm{PN}$ rendet növel a járulékokon (ugyanis az $S_{i} / L \simeq \mathcal{O}(1 / c)$, ahol $S_{i}$ az egyes testek spinvektorainak nagysága és $L$ a pálya-impulzusmomentum vektor nagysága). További lineáris perturbációk még az ún. kvadrupól-monopól (QM) és a mágneses dipól-mágneses dipól (DD) kölcsönhatások. A QM egy kvadrupól térben lévő monopól részecske járuléka, a DD pedig két mágneses dipólmomentum közti kölcsönhatást ír le. A QM és DD járulékok 2 PN rendü effektusok ${ }^{3}$. A kettős rendszer véges méretéből adódó lineáris perturbációk vizsgálata (SO, SS, QM és DD) fontos a mozgás dinamikájának meghatározásának szempontjából, ugyanis a gravitációs hullámok keltését befolyásolhatják.

A lineáris perturbációk kezelésére az égi mechanikában az oszkuláló pályaelemek módszerét használják, amelyben a perturbációk a kepleri mozgáshoz képest a pályaelemek „,kicsiny” változásában rejlenek. A 6 pályaelemmel (fél nagytengely, excentricitás, felszálló csomó hossza, pericentrum argumentuma, inklináció és a pericentrum-átmenet időpontja) a perturbációk egyszerúbben tárgyalhatók. Az első 5 pályaelem ekvivalens a dinamikai állandókkal, vagyis az energiával, a pálya-impulzusmomentummal és a Laplace-RungeLenz vektorral, a 6 . pályaelem, pedig a mozgás dinamikájával áll kapcsolatban. Az általános perturbáló erő (Brumberg erő [31, 32]) jelenlétében felírhatók az oszkuláló

\footnotetext{
${ }^{3}$ A DD kölcsönhatás akkor 2 PN rendú effektus, ha mindkét komponens legalább $10^{16} G$ mágneses térerősséggel rendelkezik, az ilyen pulzárok a magnetárok (jelenlegi megfigyelésekben a legmagasabb magnetár $\left.10^{15} G\right)$
} 
pályaelemek elsőrendü differenciálegyenletei, amelyek a Lagrange planetáris-egyenletek. A planetáris-egyenletek nem minden esetben csatolhatók szét radiális és szögrészre. A Lagrange-formalizmus használatával megtalált mozgásállandók segítségével leválasztható az esetek többségében a radiális mozgás. Gergely, Perjés és Vasúth a radiális mozgás megadására olyan módszert dolgoztak ki, amellyel a radiális egyenletben megjelenő integrálok egyszerüen kiértékelhetők [33]. A leírás kidolgozása során, a valódi és excentrikus anomália paraméterezést általánosították a fordulópontok segítségével, majd komplex változókat vezettek be, amellyel a fellépő integrálok a reziduum-tétel révén már könnyen számolhatóvá váltak. Ezen egyenletekben a perturbáló tagok együtthatói állandók voltak, amely SO és PN esetre igaz. A SS, QM és DD esetekben a perturbációs koefficiensek a valódi anomália harmonikus függvényei, ezért felmerül a kérdés, hogy SS, QM és DD esetén alkalmazható-e hasonló leírás.

A dolgozat fó célja a kompakt kettős rendszerek dinamikájának vizsgálata a poszt-newtoni formalizmus segítségével, valamint a gravitációs sugárzás által okozott pályafejlődés bemutatása, melyet a PN rendeken kívül, a testek fizikai jellemzői, a spin, a tömeg kvadrupól-momentum és a mágneses dipólmomentum befolyásolhatnak.

A dolgozat felépítését tekintve 9 fejezetből áll, a 3. és a 4. fejezetben a gravitációs hullámok alapjait és a PN formalizmust mutatom be, az 5.-9. fejezetben, pedig az új tudományos eredményeimet részletezem, melyek két fő részre különíthetők el, a kettős rendszerek klasszikus mozgására (5.-7.) és a mozgás disszipatív részére, melyet gravitációs sugárzás okoz (8., 9.). A fejezetek rövid címszavakban: 5. radiális mozgás; 6. általánosított radiális mozgás; 7. szögmozgás; 8. gravitációs sugárzás; 9. gravitációs sugárzás magasabb rendekben.

A továbbiakban a fejezetek rövid tartalmát ismertetem.

$\mathrm{Az}$ 5. fejezetben a PN, SO, SS, QM és DD kölcsönhatások által korrigált radiális mozgást mutatom be a lineáris perturbációszámítás segítségével. A radiális egyenlet integrálása az általánosított valódi anomália paraméterezés [33] segítségével adható meg. Az általánosított excentrikus anomália paraméterezés használatával felírható az égi mechanikában jól ismert Kepler-egyenlet [34] olyan általánosítása, amely a fentebb felsorolt fizikai effektusokat tartalmazza [35]. A felsorolt kölcsönhatások közül csak a SO járulék mozgásegyenlete, így a Lagrange-függvénye függ az SSC mértékválasztástól [36]. Egy rövid alfejezetben kitérek az általam elsőként felírt SSC II és III, illetve a korábban is ismert SSC I mértékekben felírt SO Lagrange-függvényekből származtatható mozgásállandókra és radiális egyenletekre, valamint bemutatom az SSC I és II mértékek közti transzformációt. Az előbbiek megadásához a ,,kiterjesztett” Lagrange-formalizmust használtam, ugyanis az SSC I és III esetekben a SO Lagrange függvények gyorsulásfüggők. A fejezet végén rövid összefoglalást adok a radiális mozgás körpálya határátmenetére. 
A 6. fejezetben az általános perturbált kéttest-probléma radiális részét mutatom be. Az erről szóló korábbi leírás [33] kiterjeszthető volt olyan általános radiális egyenletre is, ahol a perturbáló tagok együtthatója a valódi anomália harmonikus függvénye. Ezen általánosításra igaz, hogy a kétféle anomália (valódi és excentrikus) használatával, a perturbáló tagokban bizonyos együtthatókra való feltétel esetén az integrálok egyszerüen kiértékelhetők [37]. Az integrálokban látszólag fellépő szingularitások a regularitási feltétellel eltüntethetők, melyekre példákat az 5. fejezetben tárgyalt fizikailag érdekes eseteken keresztül mutatom be.

A 7. fejezetben a vezetőrendü PN és SO járulékok szögmozgásra gyakorolt hatását részletezem. Az égi mechanikában használatos ,,szög” pályaelemekhez hasonlóan Eulerszögek vezethetők be, melyekkel szemléletesen adhatók meg a testek szögmozgása. Az Euler szögeket a $\mathbf{J}=\mathbf{L}+\mathbf{S}$ megmaradó ( $\mathbf{L}$ a pálya-impulzusmomentum és $\mathbf{S}$ a spin vektorok) teljes impulzusmomentumhoz rögzített inerciális koordinátarendszerben lehet felírni, melyekben az Euler-szögekre vonatkozó fejlődési egyenleteket, illetve azok szekuláris változásainak kiszámolási módját ismertetem.

A 8. fejezetben a körpálya esetben mutatom be a gravitációs hullám frekvenciájának időfüggését és a kettős keringéseinek számát a spirálozási korszak végéig a fentebb felsorolt lineáris perturbációk figyelembevételével. Elsőként adom meg a gravitációs sugárzásból kapható fázisban az ún. önspin járulékot (SS-self) ${ }^{\mathbb{U}}$. Ismertetem, hogy a gravitációs hullám frekvenciájában a kettős rendszerekre a SS-self járulék nagyobb tud lenni a SS járuléknál [39] egy ,,nagy” és egy ,,kicsi” spinnel $\left(S_{i}\right.$ spinvektorok nagysága) rendelkező kettősben.

A 9. fejezetben a magasabb rendü $(3 \mathrm{PN})$ korrekciókat tárgyalom a gravitációs hullámok fázisában. Ismert, hogy a spinek figyelembevételével a rendszer szögmozgásához a spinprecessziós egyenletek csatolódnak, ezáltal a gravitációs hullámok fázisában a vezetőrendü spinprecessziós egyenletek által okozott korrekciók is fellépnek. Kiderült, hogy a vezetőrendü spinprecesszió, a 3 PN rendben módosítja a gravitációs sugárzás SS járulékát, ami egyenlő tömegű esetben nem lép fel, viszont nem-egyenlő tömegü esetben ezen járulék periodikus lesz a $T_{3 P N S S}$ periódusidővel, amely rendjét tekintve $\varepsilon^{-1}$ el nagyobb, mint a gravitációs hullám periódusa $\left(T_{G W}\right)$. Ezáltal bevezethető a gravitációs hullámok fázisába egy 2 PN rendü ún. renormált spinparaméter, amely időfüggetlen és az állandó része $3 \mathrm{PN}$ rendü. A fejezet végén a SS, renormált SS és a spinprecesszió numerikus fejlődéséből kapható járulékokat hasonlítom össze a gravitációs hullámok keringéseinek számában.

\footnotetext{
${ }^{4}$ A SS kölcsönhatásból számolt energiaveszteségben megjelennek a spinnagyságok szorzataival arányos tagokon kívül az egyes spinek négyzeteivel arányos tagok is, ez utóbbi a önspin járulék. [38].
} 


\section{Gravitációs hullámok}

A továbbiakban a gravitációs hullámok keletkezésének alapjait mutatom be. Az általános relativitáselmélet alapegyenlete az Einstein-egyenlet

$$
G_{a b}+\Lambda g_{a b}=\frac{8 \pi G}{c^{4}} T_{a b}
$$

ahol a baloldalon szereplő $G_{a b}$ az Einstein-tenzor, amely a téridő geometriáját írja le. A $G_{a b}$ a Riemann-geometriában használt $g_{a b}$ metrikus tenzorból építhető fel, amely a $g_{a b}$-nek másodrendü deriváltjait is tartalmazza $\left(G_{a b}=f(g, \partial g, \partial \partial g)\right)$. Így a (B.]) Einstein-egyenlet egy másodrendü csatolt parciális differenciálegyenlet-rendszert alkot. A jobboldalon szereplő $T_{a b}$ mennyiség az energia-impulzus tenzor, amely az anyagmező tulajdonságait hordozza. A $\Lambda g_{a b}$ tagot (ahol $\Lambda$-t kozmológiai állandónak nevezzük), attól függően, hogy melyik oldalra írjuk, lehet a $G_{a b}$, illetve a $T_{a b}$-hoz kapcsolva értelmezni. Ha a baloldalon szerepel, akkor a téridő geometriájában jelenik meg. Jobboldalon használva anyagmezőként értelmezik, mely a kozmológiai elméletekben a sötét energia legegyszerübb jelöltje.

A (B.]) egyenlet valójában 10 egyenlet, mivel az Einstein-egyenletben szereplö tenzorok szimmetrikusak. A (B.]) mindkét oldaláról megköveteljük a kovariáns divergenciájának az eltűnését, melynek eredményeképp az egyenlet baloldalából a $\nabla_{a}\left(G^{a b}+\Lambda g^{a b}\right)=0$ a matematikai Bianchi-azonosságokat kapjuk, a jobboldalából pedig a $\nabla_{a} T^{a b}=0$ egyenletet, mely az anyagmegmaradással kapcsolatos.

A továbbiakban összefoglalom az Einstein-egyenlet lineáris közelítéséből adódó gravitációs hullámok származtatását $\Lambda=0$ esetben.

\subsection{A gyengetér közelítés}

A gyengetér közelítésnél feltesszük, hogy a gravitációs tér nem túl jelentős, ezért létezik olyan koordinátarendszer, ahol a téridőt meghatározó $g_{a b}$ metrika felbontható egy $\eta_{a b}$ Minkowski $\left(\eta_{a b}=\operatorname{diag}(-1,1,1,1)\right)$ és egy $h_{a b}$ lineáris perturbációra $\left(\left|h_{a b}\right|<<1\right)^{\mathbf{g}}$

$$
g_{a b}=\eta_{a b}+h_{a b} .
$$

A továbbiakban a téridő indexeket az $\eta_{a b}$ Minkowski metrikával „,húzzúk fel és le” (kontraháljuk). A geometriai mennyiségek származtatása során feltehető, hogy a gravitáció lassan változik, vagyis $\partial_{0} g_{a b}=\partial_{0} h_{a b}=0 . \quad \mathrm{A}$ (B.2) $g_{a b}$ metrikából kiszámolhatóak lineáris rendig a Christoffel-szimbólumok, a Riemann-, Ricci-tenzorok és

\footnotetext{
${ }^{5}$ Megjegyzendő, hogy ezen egyszerü tárgyalás mellett, ez a felbontás elvégezhető tetszőleges $g_{a b}^{B}$ háttérmetrika és egy azon lévő $h_{a b}$ lineáris perturbációra, amely megtalálható a [41]] irodalomban.
} 
a Ricci-skalár

$$
\begin{aligned}
\Gamma_{a b}^{c} & =\frac{\eta^{c e}}{2}\left(\partial_{a} h_{b e}+\partial_{b} h_{a e}-\partial_{e} h_{a b}\right), \\
R_{b c d}^{a} & =\frac{\eta^{c e}}{2}\left(\partial_{b} \partial_{c} h_{a d}+\partial_{d} \partial_{a} h_{b c}-\partial_{b} \partial_{d} h_{a c}-\partial_{a} \partial_{c} h_{b d}\right), \\
R_{a b} & =\frac{1}{2}\left(\partial_{e} \partial_{b} h_{a}^{e}+\partial_{e} \partial_{a} h_{b}^{e}-\square h_{a b}-\partial_{a} \partial_{b} h\right), \\
R & =-\partial_{e} \partial^{f} h_{f}^{e}+\square h
\end{aligned}
$$

ahol $h=h_{a}^{a}$ a $h_{a b}$ spúrja és $\square=\partial_{a} \partial^{a}$ a d'Alambert operátor. Az Einstein-tenzort, az előző mennyiségekből felírva a következő alakú lesz

$$
G_{a b}=\frac{1}{2}\left(\partial_{e} \partial_{b} h_{a}^{e}+\partial_{e} \partial_{a} h_{b}^{e}-\square h_{a b}-\partial_{a} \partial_{b} h-\eta_{a b} \partial_{e} \partial^{f} h_{f}^{e}+\eta_{a b} \square h\right)
$$

A $h_{a b}$ helyett használható a $\bar{h}_{a b}=h_{a b}-h \eta_{a b} / 2$ ún. ,,spúrmegfordított" metrika, amely segítségével az Einstein-egyenletek egyszerübbek lesznek

$$
\frac{1}{2} \partial_{e} \partial_{(b} \bar{h}_{a)}^{e}-\frac{1}{2} \square \bar{h}_{a b}-\frac{1}{2} \eta_{a b} \partial_{e} \partial^{f} \bar{h}_{f}^{e}=\frac{8 \pi G}{c^{4}} T_{a b} .
$$

Az előbbi egyszerüsítés során a $\partial^{a} \bar{h}_{a b}$ mennyiség általában nem tünik el. A diffeomorfizmus invarianciából következik, hogy lehetséges olyan mértékválasztás, amelyben a $\partial^{a} \bar{h}_{a b}$ mennyiség eltüntethető

$$
\partial^{a} \bar{h}_{a b}=0
$$

A metrikának ilyen jellegü kifejezését harmonikus- vagy Lorentz (néhol de Donder) -mértéknek nevezik ${ }^{6}$. A diffeomorfizmus invariancia azt jelenti, hogy vannak olyan infinitezimális koordináta transzformációk, melyek mértékszabadsághoz vezetnek. Egy ilyen koordináta transzformációt tekintve a következő egyenletet kapjuk

$$
x^{\prime a}=x^{a}+\xi^{a}(x)
$$

ahol $\xi^{a}(x)$ tetszőleges lineáris rendü függvénye a koordinátáknak. Ebben az esetben a (B.T0) egyenletre igaz a $\partial x^{\prime a} / \partial x^{b}=\delta_{b}^{a}+\partial_{b} \xi^{a}(x)$ kifejezés, melynek inverz transzformációja

$$
\frac{\partial x^{a}}{\partial x^{\prime b}}=\delta_{b}^{a}-\partial_{b} \xi^{a}(x)
$$

\footnotetext{
${ }^{6}$ Ez hasonló, mint az elektrodinamikában az $A_{a}$ vektorpotenciálra vonatkozó $\partial_{a} A^{a}=0$ Lorentzmérték.
} 
ahol a $\partial x^{a} / \partial x^{b}=\Lambda_{b}{ }^{a}$, vagyis a globális Lorentz-transzformáció. Ekkor a metrika transzformációja lineáris rendig a (3.10) egyenlet felhasználásával a következő lesz

$$
g_{a b}^{\prime}=\Lambda_{a}{ }^{c} \Lambda_{a}{ }^{d} g_{c d}=\eta_{a b}+h_{a b}-\partial_{a} \xi_{b}-\partial_{b} \xi_{a}
$$

ahol $\xi_{a}=\eta_{a c} \xi^{c}$. Látható, hogy a spúrmegfordított metrikára a transzformáció az alábbi

$$
\bar{h}^{a b}=h^{a b}-\partial^{a} \xi^{b}-\partial^{b} \xi^{a}+\eta^{a b} \partial_{c} \xi^{c}
$$

melynek parciális deriváltjából $\left(\partial_{b}\right)$ megkapjuk a mértékszabadság feltételét ${ }^{\mathbf{0}}$

$$
\square \xi^{a}=\partial_{b} h^{a b}
$$

Vagyis a (3.14) inhomogén egyenlet megoldásával a (3.9) Lorentz-mérték fennáll (amennyiben a $\square \xi^{a}=0$ egyenletet is megköveteljük $\xi^{a}$-ra, akkor bármely ([.T3) transzformációval $\bar{h}^{\prime a b}$-re teljesül a Lorentz-mérték). Végeredményképpen Lorentzmértékben az Einstein-egyenletek linearizált alakja

$$
\square \bar{h}_{a b}=\frac{16 \pi G}{c^{4}} T_{a b}
$$

A linearizált-egyenletek vákuum megoldásait tekintjük gravitációs hullámoknak. Tehát a megoldandó egyenlet

$$
\square \bar{h}_{a b}=0
$$

A következő alakú síkhullámmegoldást tesszük fel a (3.16) vákuum linearizált egyenletek megoldására

$$
\bar{h}_{a b}=A^{a b} e^{i k_{c} x^{c}}
$$

ahol $A^{a b}$ egy általános szimmetrikus állandó tenzor, melynek komponensei általában komplex síkhullám amplitúdók és $k_{a}$ egy állandó valós négyesvektor (elektrodinamikai analógiával az ún. hullámszámvektor). Konvencionálisan legyen $k_{a}=(\omega / c, \mathbf{k})$, ahol $\omega$ a hullám körfrekvenciája és $\mathbf{k}$ a közönséges háromdimenziós hullámszámvektor. A (3.17) megoldást használva a ([.T6) egyenletben megkapjuk, hogy $k^{a} k_{a}=0$, vagyis $k_{a}$ nullvektor (hossza zérus). Ennek fényében a diszperziós reláció az $\omega^{2}=c^{2} \mathbf{k}^{2}$ lesz, amelyből következik, hogy a gravitációs hullám csoport- és fázissebessége a fénysebesség. A fentebb említett okok miatt, a Lorentz-mértékkel még maradnak szabadsági fokok, tehát a (3.T7) megoldásban nincsen teljesen rögzítve a koordinátarendszer. Ennek megértéséhez a ([.T7) síkhullámmegoldást kell megvizsgálni.

\footnotetext{
${ }^{7}$ Hasonlóan mint elektrodinamikában a $A_{a}^{\prime}=A_{a}+\partial_{a} \psi$ mértéktranszformációra, ahol $\psi$-nek a $\square \psi=0$ et kell teljesíteni.
} 
Mivel $A^{a b}$ szimmetrikus tenzor, ezért 10 független komponense van. A Lorentzmérték megkövetelésével a szabadsági fokok lecsökkennek 6-ra. A továbbiakban [4]] jelöléseit követve, megmutatjuk, hogy a 6 szabadsági fokból csak 2 független, amely a gravitációs síkhullámok lehetséges polarizációs állapotai (általános esetben a Riemanntenzor komponenseinek vizsgálatával 6 polarizációs állapot adódik 2 . ábra).

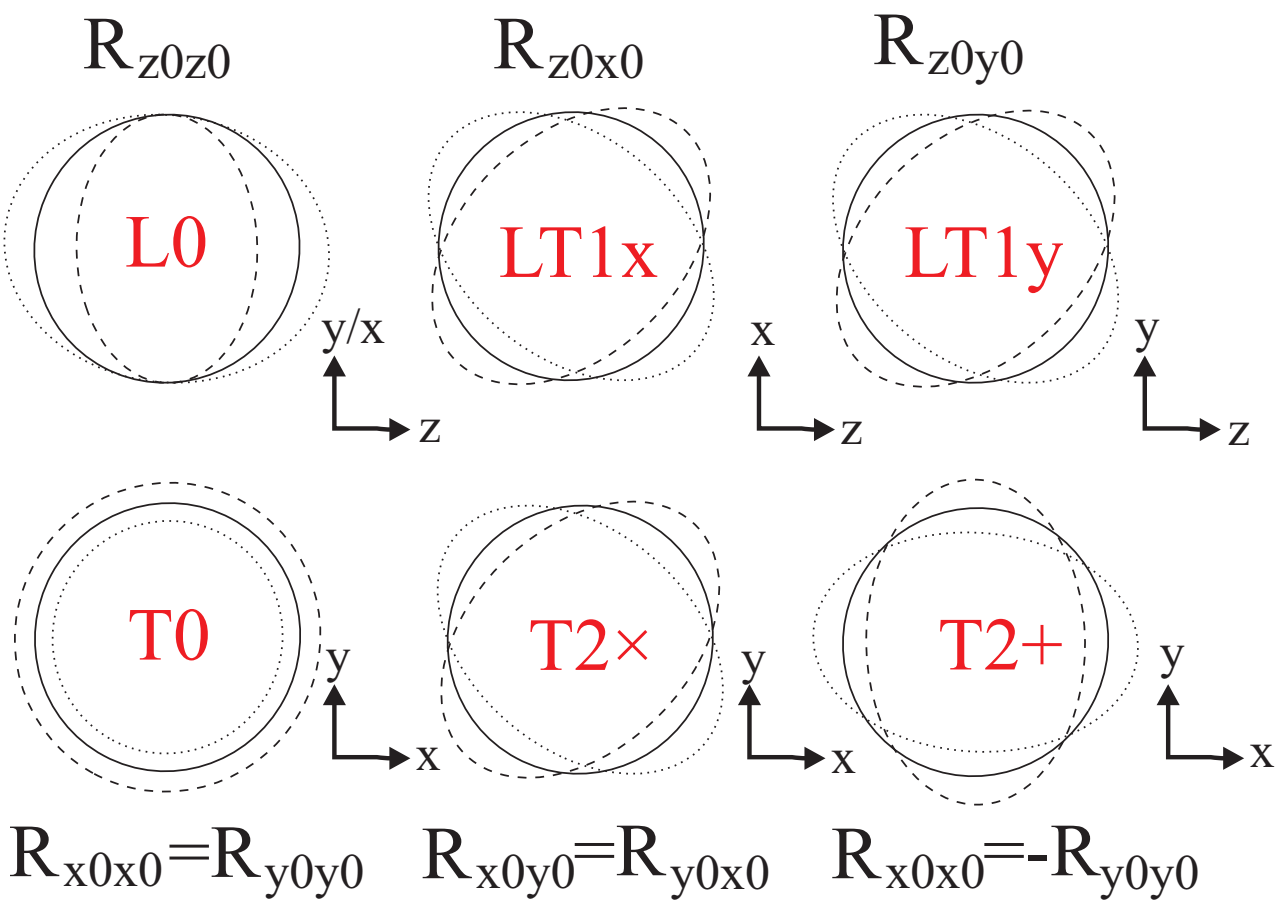

2. ábra. Általános esetben a gravitációs hullámnak 6-féle polarizációs állapota van, L jelenti a longitudinális és T a transzverzális hullámterjedést. A 0,1 és 2 jelölések a graviton helicitására (spinjére) utalnak. A vákuum linearizált Einstein-egyenletekből az utolsó 2 polarizációs állapot adódik, vagyis a $T 2 \times$ és $T 2+$ gravitációs hullám transzverzális és spinje 2 .

Tegyük fel, hogy a $k_{a}$ hullámszámvektor alakja $k_{a}=(k, 0,0, k)$ és jelöljük $A^{a b}$ amplitúdótenzor komponenseit $a^{a b}$-kel. A (3.17) síkhullám megoldásból és a Lorentzmértékfeltételből következik, hogy $A^{a b} k_{a}=0$, így $A^{a 3}=A^{a 0}$. Tehát az $A^{a b}$ amplitúdótenzor a következő alakú lesz

$$
A^{a b}=\left(\begin{array}{cccc}
a^{00} & a^{01} & a^{02} & a^{00} \\
a^{01} & a^{11} & a^{12} & a^{01} \\
a^{02} & a^{12} & a^{22} & a^{02} \\
a^{00} & a^{01} & a^{02} & a^{00}
\end{array}\right)
$$

Ezek után a $\square \xi^{a}=0$ feltételt megvizsgálva $\xi^{a}$ mennyiségre, a (3.T7) egyenlethez hasonló síkhullám megoldás kapható

$$
\xi^{a}=\varepsilon^{a} e^{i k_{c} x^{c}}
$$

ahol $\varepsilon^{a}$ egy állandó négyesvektor. A (B.T7), a (3.T. és) és (B.T3) egyenleteket használva, 
felírható egy transzformáció az $A^{a b}$ amplitúdótenzorra, amelyben már csak $\varepsilon^{a}$ és $k^{a}$ mennyiségek szerepelnek

$$
A^{\prime a b}=A^{a b}-i \varepsilon^{a} k^{b}-i \varepsilon^{b} k^{a}+i \eta^{a b} \varepsilon^{c} k_{c}
$$

A $k_{a}$ hullámszámvektor fentebb feltett alakját figyelembe véve, megmutatható, hogy az $A^{a b}$ tenzor komponensei a következők

$$
a^{\prime 00}=a^{\prime 01}=a^{\prime 02}=0, \quad a^{\prime 11}=-a^{\prime 22},
$$

mellyel bebizonyítottuk, hogy a gravitációs hullámok lehetséges szabadsági fokainak száma 2. A $a^{\prime 11}=h_{+}$és $a^{12}=h_{\times}$az irodalomban is használt ún. polarizációs állapot jelölést bevezetve, felírhatjuk az $A^{a b}$ amplitúdótenzor végleges alakját (vesszőket elhagyva)

$$
A^{a b}=\left(\begin{array}{cccc}
0 & 0 & 0 & 0 \\
0 & h_{+} & h_{\times} & 0 \\
0 & h_{\times} & -h_{+} & 0 \\
0 & 0 & 0 & 0
\end{array}\right)
$$

Az így felírt speciális $A^{a b}$ amplitúdótenzor a TT- (transverse-traceless) vagy sugárzásimérték megkövetelésével közvetlenül is megkapható. A TT-mérték definíciója a következö (spúrmentes és transzverzális) ${ }^{\mathbb{1}}$

$$
\bar{h}_{T T}^{0 a}=0, \quad \text { és } \quad \bar{h}_{T T}=0 .
$$

A TT-mértékben a Lorentz-mértékfeltétel automatikusan teljesül $\left(\partial_{a} \bar{h}_{T T}^{a b}=0\right)$ és csak a térszerü komponensek nem-eltűnőek.

A $h_{T T}$ gravitációs hullám tenzoriális jellegéből adódóan a 2-es spinü (pontosabban 2-es helicitású [42]) tömegtelen részecskét, az ún. gravitont írja le. Az inhomogén linearizált Einstein-egyenletben 6-féle polarizációs állapot létezik, melyek spinje 0, 1 és 2 lehet (2】. ábra $)^{\text {I]. }}$.

Anyag jelenlétében a gravitációs hullámokra a (3.15) inhomogén egyenlet formális megoldása adható, amely a következő (hasonlóan, mint az elektrodinamikában)

$$
\bar{h}^{a b}(c t, \mathbf{x})=-\frac{4 G}{c^{4}} \int \frac{T^{a b}(c t-|\mathbf{x}-\mathbf{y}|, \mathbf{y})}{|\mathbf{x}-\mathbf{y}|} d^{3} \mathbf{y}
$$

\footnotetext{
${ }^{8}$ Megjegyzendő, hogy a TT-mérték a $h_{a b}$ mértéktenzorra is ugyanilyen alakú.

${ }^{9}$ Hasznos fogalom még az ún. visszatérési szög, amely az a legkisebb szög, mellyel elforgatva a gravitációs hullámok frontjában az erővonalakat (polarizációs állapotokat), visszakapjuk az eredeti alakzatot. Tehát a 2 -esre $180^{\circ}$, az 1 -esre $360^{\circ}$ és a 0 spinü gravitonra $0^{\circ}$ a visszetérési szög.
} 
A megoldást a retardált Green-függvények segítségével lehet előállítani, amely analitikusan nehéz feladat. Kényelmesebb az elektrodinamikában is használt multipólsorfejtést alkalmazni, melynek lényege, hogy a forrás távol van a megfigyelőtől, így a (5.24) egyenletben szereplő $|\mathbf{x}-\mathbf{y}|^{-1}$ tag közelítése az alábbi lesz

$$
|\mathbf{x}-\mathbf{y}|^{-1}=\frac{1}{r}+y^{\alpha} \frac{x_{\alpha}}{r^{3}}+y^{\alpha} y^{\beta} \frac{3 x_{\alpha} x_{\beta}-\delta_{\alpha \beta}}{r^{5}}+\ldots,
$$

ahol $r=|\mathbf{x}|$. Az általános multipól-sorfejtés alapján a (324) megoldás a következőképpen írható fel

$$
\bar{h}^{a b}(c t, \mathbf{x})=-\frac{4 G}{c^{4}} \sum_{n=0}^{\infty} \frac{(-1)^{n}}{n !} I^{a b i_{1} i_{2} \ldots i_{n}}(c t-|\mathbf{x}-\mathbf{y}|) \partial_{i_{1}} \partial_{i_{2}} \ldots \partial_{i_{n}}\left(\frac{1}{r}\right),
$$

ahol $I^{a b i_{1} i_{2} \ldots i_{n}}$ a forrás multipólmomentumai. Az $I^{a b i_{1} i_{2} \ldots i_{n}}$ momentumok az energiaimpulzus tenzorból származtathatók a következőképpen

$$
I^{a b i_{1} i_{2} \ldots i_{n}}(c t)=\int T^{a b}(c t, \mathbf{y}) y^{i_{1}} y^{i_{2}} \ldots y^{i_{n}} d^{3} \mathbf{y}
$$

Látható, hogy a multipólmomentumok a forrás $r$ távolságával $1 / r^{n+1}$ mennyiség szerint csengenek le, így az egyenletekben elegendő az első néhány tagot használni, amely kompakt kettősökre jól alkalmazható.

A (3.15) egyenletben nem definiáltam a $T^{a b}$ energia-impulzus tenzort, mely az anyag hiányában a gravitációnak megfelelő energia-impulzussal egyezik meg. A gravitációs tér energia-impulzus tenzorának definiálása nem egyszerű feladat az általános relativitáselméletben. A linearizált elméletben a következőt tesszük fel a jobboldalon

$$
G_{a b}^{(1)}=\frac{8 \pi G}{c^{4}}\left(T_{a b}+\tau_{a b}\right)
$$

ahol $G_{a b}^{(1)}$ a (3.7)-vel értelmezett lineáris rendü tenzor, $\tau_{a b}$ a gravitációs tér, míg $T_{a b}$ az anyag energia-impulzus tenzora. Többféle választás adódik a $\tau_{a b}$ tenzor származtatására,ezek közül az egyik módszer a Landau és Lifsic által javasolt energiaimpulzus pszeudotenzor [43], melynek a neve is mutatja, hogy a $\tau_{a b}$ nem úgy transzformálódik, mint egy tenzor 四.

\subsection{Kompakt források leírása}

A kompakt források olyan asztrofizikai objektumok, melyek sugarai összemérhetőek a tömegükkel ( $G=c=1$ egységekben). Ezen rendkívül ,,sürü” anyagok a bevezetőben is

\footnotetext{
${ }^{10}$ Létezik más kiterjesztése a $\tau_{a b}$ pszeudotenzornak az irodalomban, például Einstein, Papapetrou, Bergmann-Thompson, Møller és Weinberg által javasoltak.
} 
említett fekete lyukak, neutroncsillagok és a fehér törpék, melyek a csillagok gravitácós kollapszusa révén jöhetnek létre.

A legkisebbek a fehér törpék, melyeknek tömege körülbelül $(0.2-0.6) M_{\odot}$, a mai elméletek szerint a szupernóva robbanásból jöttek létre. Az 1.44M $\odot$ az ún. Chandrasekhar-határ, amely limitálja a fehér törpék maximális tömegét. Amennyiben egy csillag belső magfúziójából eredő felfúvódása megáll, akkor kezdődik el a gravitációs összehúzódás, a kollapszus. Ha a csillag kezdeti tömege kisebb, mint a Chandrasekhar-határ, akkor a csillagban lévő elektronok degenerációs nyomása megállítja az összehúzódást és stabil fehér törpe keletkezik. Amennyiben a csillag kezdeti tömege nagyobb, mint a Chandrasekhar-határ, akkor kollapszus tovább folytatódik és a kezdeti objektum egy fekete lyukká, vagy neutroncsillaggá válik (melynek határa jelenlegi ismereteink szerint $(1.7-2.7) M_{\odot}$-nél van).

A neutroncsillag tömege körülbelül $1.4 M_{\odot}$, sugara $\mathrm{kb}$. $10 \mathrm{~km}$, melyek szintén szupernóva robbanások maradványaiból jöhetnek létre. Az első neutroncsillag modellt Oppenheimer, Volkoff és Tolman alkotta meg 1939-ben [44], [45], melynek segítségével a kollapszus eredményeként létrejött fehér törpe maximálisan elérhető tömegét $0.75 M_{\odot}$ re jósolták meg. A csillagászok 1967-ben fedezték fel először a neutroncsillagot, amely rádiótartományban volt mérhető.

A fekete lyukak tömegüket tekintve igen széles skálán mozognak $\left(10^{1}-10^{16}\right) M_{\odot}$. A jelenleg ismert legkisebb tömegü fekete lyuk feltehetően az XTE J1650-500 kettős rendszer egyik komponense, ami kb. 3.8 $M_{\odot}$ nagyságú. A galaxisok magjaiban nagytömegü (szupermasszív) kb. $\left(10^{7}-10^{10}\right) M_{\odot}$ fekete lyukak találhatók, amelyek közül az eddig ismert legnagyobb tömegü az OJ 287 galaxis magja, amely vélhetően egy $1.8 \times 10^{10} M_{\odot}$ nagyságú fekete lyuk [46]. Ezek után a multipólsorfejtés segítségével meghatározzuk a gravitációs hullámokat a kompakt kettős rendszerekre.

A továbbiakban feltesszük, hogy a kompakt forrás messze van a megfigyelőtől $(|\mathbf{x}-\mathbf{y}| \approx R)$ és a kompakt objektum mozgásának sebessége sokkal kisebb, mint a fénysebesség $(v \ll c)$. Így a ( $(\mathbf{3 2 6})$ egyenlet egyszerűen felírható

$$
\bar{h}^{a b}(c t, \mathbf{r})=-\frac{4 G}{c^{4} R} \int T^{a b}(c t-R, \mathbf{y}) d^{3} \mathbf{y}
$$

A kapott integrál alapján azonosítani lehet a kompakt test teljes energiáját $\left(m c^{2}=\right.$ $\left.\int T^{00} d^{3} \mathbf{y}\right)$, teljes impulzusmomentumát $\left(c \mathbf{P}^{\alpha}=\int T^{0 \alpha} d^{3} \mathbf{y}\right)$, illetve a forrás feszültség komponenseit $\left(\int T^{\alpha \beta} d^{3} \mathbf{y}\right)$. Amennyiben a forrás izolált, akkor az $m$ és $\mathbf{P}^{\alpha}$ megmaradó mennyiségek az energia-impulzus tenzor megmaradási $\left(\partial_{a} T^{a b}=0\right)$ egyenletéből következnek (természetesen az izolált forrás úgy értendő, hogy a sugárzás által okozott veszteségeket nem vesszük figyelembe). Ezek után felírjuk a $\bar{h}^{a b}$ metrikát a forrás 
tömegközépponti rendszerében az $x^{\alpha}$ térkoordináták szerint, így $\mathbf{P}^{\alpha}=0$, tehát

$$
\bar{h}^{00}=-\frac{4 G m}{c^{2} R}, \quad \bar{h}^{0 \alpha}=\bar{h}^{\alpha 0}=0,
$$

és a metrika térszerü $\left(\bar{h}^{\alpha \beta}\right)$ része

$$
\bar{h}^{\alpha \beta}(c t, \mathbf{R})=-\frac{4 G}{c^{4} R} \int T^{\alpha \beta}(c t-R, \mathbf{y}) d^{3} \mathbf{y}
$$

Ezen integrál kiszámítása meglehetősen fáradtságos, ezért a meghatározására egyszerűbb a megmaradási egyenletet $\left(\partial_{a} T^{a b}=0\right)$ használni, melyből

$$
\begin{aligned}
\partial_{0} T^{00}+\partial_{\alpha} T^{0 \alpha} & =0, \\
\partial_{0} T^{\alpha 0}+\partial_{\alpha} T^{\alpha \beta} & =0 .
\end{aligned}
$$

A kövekező integrált tekintve

$$
\int \partial_{\alpha}\left(T^{\alpha \beta} y^{\gamma}\right) d^{3} \mathbf{y}=\int\left(\partial_{\alpha} T^{\alpha \beta}\right) y^{\gamma} d^{3} \mathbf{y}+\int T^{\alpha \gamma} d^{3} \mathbf{y}
$$

ahol az integrálás a forrás térfogatára van értelmezve, emiatt a határfelületen az energiaimpulzus tenzor eltűnik $\left(T^{\alpha \beta}=0\right)$. A Gauss-tétel alapján a (B.34) egyenlet baloldala átalakítható felületi integrállá, amely zérus lesz a határfelületre kirótt feltétel miatt. Így a (B.34) és (B.33) egyenletek alapján

$$
\int T^{\alpha \gamma} d^{3} \mathbf{y}=-\int\left(\partial_{\alpha} T^{\alpha \beta}\right) y^{\gamma} d^{3} \mathbf{y}=\partial_{0} \int T^{\alpha 0} y^{\gamma} d^{3} \mathbf{y}=\frac{1}{2} \partial_{0} \int\left(T^{\alpha 0} y^{\gamma}+T^{\alpha 0} y^{\gamma}\right) d^{3} \mathbf{y}
$$

ahol az utolsó lépésben szimmetrizáltuk az integrandust. Egy másik integrált vizsgálva

$$
\int \partial_{\alpha}\left(T^{0 \alpha} y^{\beta} y^{\gamma}\right) d^{3} \mathbf{y}=\int\left(\partial_{\alpha} T^{0 \alpha}\right) y^{\beta} y^{\gamma} d^{3} \mathbf{y}+\int\left(T^{0 \gamma} y^{\beta}+T^{0 \gamma} y^{\beta}\right) d^{3} \mathbf{y}
$$

melynél az előző okok miatt a baloldal zérus és a (3.32) egyenletet felhasználva megkapjuk a (臣) egyenletből a következő kifejezést

$$
\int\left(T^{0 \gamma} y^{\beta}+T^{0 \gamma} y^{\beta}\right) d^{3} \mathbf{y}=\partial_{0} \int T^{00} y^{\beta} y^{\gamma} d^{3} \mathbf{y}
$$

A (

$$
\int T^{\alpha \gamma} d^{3} \mathbf{y}=\frac{1}{2} \partial_{0} \partial_{0} \int T^{00} y^{\beta} y^{\gamma} d^{3} \mathbf{y}
$$


A (3.3]) egyenletben felhasználva a (3.38)-t megkapjuk Einstein kvadrupól-formuláját

$$
\bar{h}^{\alpha \beta}(c t, \mathbf{R})=-\frac{2 G}{c^{4} R} \frac{d^{2} I^{\alpha \beta}}{d t^{2}}
$$

amelyben bevezettük az $I^{\alpha \beta}$ kvadrupólmomentum-tenzort

$$
I^{\alpha \beta}=\int T^{00} y^{\beta} y^{\gamma} d^{3} \mathbf{y}
$$

Hasonló levezetésekben a kvadrupól-formula kiszámolható az energia és az impulzusmomentum veszteségekre is, az alábbiak szerint

$$
\begin{aligned}
\frac{d E}{d t} & =-\frac{G}{5 c^{5}} \frac{d^{3} I_{\alpha \beta}}{d t^{3}} \frac{d^{3} I_{\alpha \beta}}{d t^{3}} \\
\frac{d L_{\gamma}}{d t} & =-\frac{2 G}{5 c^{5}} \varepsilon_{\gamma \alpha \beta} \frac{d^{2} I_{\alpha \delta}}{d t^{2}} \frac{d^{3} I_{\beta \delta}}{d t^{3}} .
\end{aligned}
$$

A $G / c^{5}$ faktor reciprokát hívják az univerzum luminozitásának, amely $3.63 \times 10^{53} \mathrm{~W}$. Érdemes megjegyezni, hogy a (3.40) és a (3.42) egyenletekre vonatkozó kvadrupólformulákban az $I^{\alpha \beta}-\mathrm{k}$ harmadik, míg a (उ.3.⿴囗) egyenletben a $\bar{h}^{\alpha \beta}$ megadásához az $I^{\alpha \beta}-\mathrm{k}$ második időderiváltjai szükségesek.

\subsection{Kepleri pálya gravitációs sugárzása}

A továbbiakban megvizsgálunk egy $m_{1}$ és $m_{2}$ tömegü kompakt kettős rendszert, amely kepleri zárt pályán mozog (tehát az $E<0$ ), vagyis a testek forgását és a mozgás magasabb rendü relativisztikus korrekcióit nem vesszük figyelembe. Megmutatható, hogy a kepleri kéttest-probléma ekvivalens az ún. egycentrum-problémával, amely egy $m=m_{1}+m_{2}$ , központi” tömeg által keltett gravitációs térben mozgó $\mu=m_{1} m_{2} / m$ redukált tömegü részecske mozgásának felel meg (3]. ábra).

A klasszikus mozgás kepleri paraméterezése a következő

$$
r=\frac{a\left(1-e^{2}\right)}{1+e \cos \chi}, \quad \frac{d \chi}{d t}=\frac{\left[G m a\left(1-e^{2}\right)\right]^{1 / 2}}{r^{2}}
$$

ahol $\chi$ a valódi anomália, $a$ a fél nagytengely, $e$ az excentricitás és $r$ a $\mu$ tömegü részecske pozíciója az $m$ központi tömegtől a pályasíkban. Egy kepleri koordinátarendszert választunk, melynél az x-tengely a pericentrumba, a z-tengely a pályasíkra merőleges irányba (pálya-impulzusmomentum vektorral párhuzamos) és az ytengely az x-z síkra merőlegesen jobbsodrású rendszert alkot. Ekkor megmutatható, hogy az egyes tömegpontok kvadrupólmomentum-tenzora $I^{\alpha \beta}=\mu x^{\alpha} x^{\beta}$ alakú. A TT-mérték használatával a kvadrupólmomentum-tenzor nem-eltűnő komponensei az $I^{x x}$, az $I^{y y}$ és az 
$I^{x y}=I^{y x}$, amelyek kepleri pályára a (3.43) paraméterezés segítségével a következő alakba írhatóak fel

$$
\begin{aligned}
I^{x x} & =\mu r^{2} \cos \chi, \\
I^{y y} & =\mu r^{2} \sin \chi, \\
I^{x y} & =\mu r^{2} \cos \chi \sin \chi .
\end{aligned}
$$

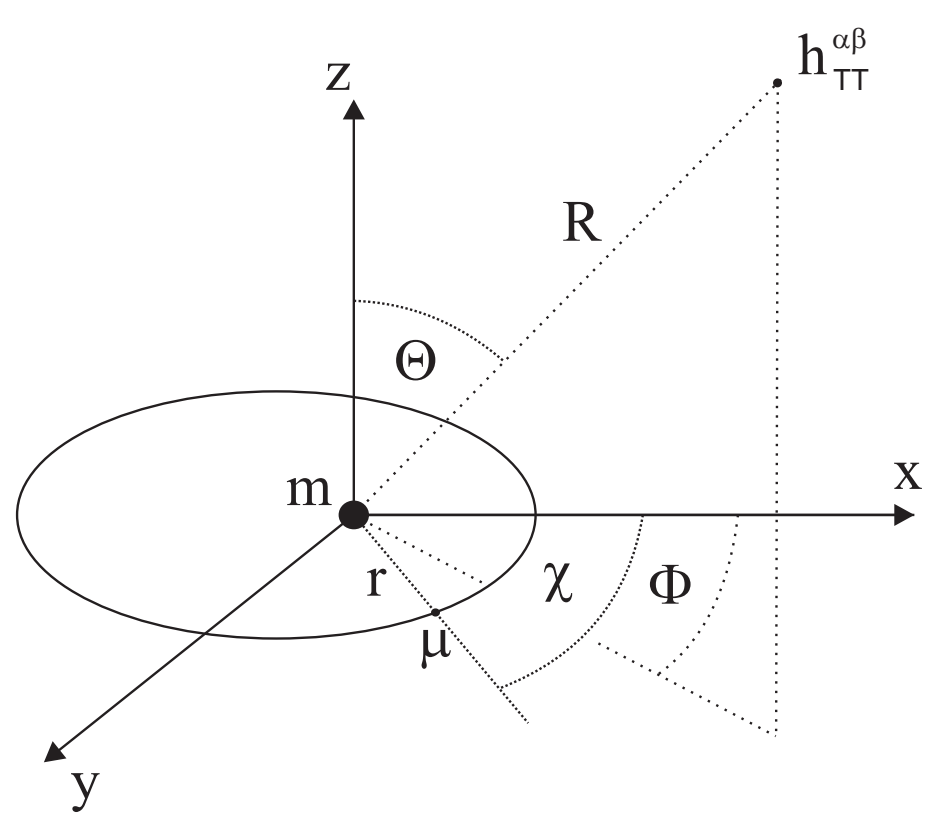

3. ábra. Kepleri pálya geometriája

A (3.3.1) kvadupól-formulát és a (3.4.3) kepleri paraméterezést használva az $I^{\alpha \beta}$ második időderiváltjaiból előállítható a gravitációs hullámalak. Ezek után gömbi polárkoordinátákat ( $R$ a forrástávolság, $\Theta$ függőleges z-tengelytől mért szög és $\Phi$ a pályasíkon a pericentrumtól ( $x$-tengelytől) mért szög) vezetünk be, melyek segítségével a $\bar{h}^{\alpha \beta}$ metrika a kettőstől való tetszőleges $R$ távolságban megadható. Ekkor az $I^{\alpha \beta}$ áttranszformálható TT-mértékbe a következőképpen $I_{T T}=P I P-P T r a c e(P I) / 2$, ahol $P$ a projekciós operátor [47]. Így az $I_{T T}^{\alpha \beta}$ explicit alakja a gömbi polárkoordinátákban az alábbi lesz

$$
I_{T T}^{\alpha \beta}=\frac{1}{2}\left(\begin{array}{ccc}
0 & 0 & 0 \\
0 & I^{\Theta \Theta}-I^{\Phi \Phi} & 2 I^{\Theta \Phi} \\
0 & 2 I^{\Theta \Phi} & I^{\Phi \Phi}-I^{\Theta \Theta}
\end{array}\right),
$$


ahol

$$
\begin{aligned}
I^{\Theta \Theta} & =\frac{\mu r^{2}}{2} \cos ^{2} \theta[1+\cos 2(\chi-\Phi)], \\
I^{\Theta \Phi} & =\frac{\mu r^{2}}{2} \cos \theta[\sin 2(\chi-\Phi)], \\
I^{\Phi \Phi} & =\frac{\mu r^{2}}{2}[1-\cos 2(\chi-\Phi)] .
\end{aligned}
$$

Bevezetve a $h_{\times}=\bar{h}_{T T}^{\Theta \Theta}$ és $h_{+}=\bar{h}_{T T}^{\Theta \Phi}$ korábban tárgyalt polarizációs állapotokat, melyek a kepleri pályára a (3.45) és (3.3.प) alapján

$$
\begin{aligned}
h_{\times}= & -\frac{G^{2} \mu m \cos \Theta}{c^{4} a\left(1-e^{2}\right) R}[(5 e \sin \chi+4 \sin 2 \chi+e \sin 3 \chi) \cos 2 \Phi \\
& \left.-\left(5 e \cos \chi+4 \cos 2 \chi+e \cos 3 \chi+2 e^{2}\right) \sin 2 \Phi\right] \\
h_{+}= & -\frac{G^{2} \mu m\left(1+\cos ^{2} \Theta\right)}{c^{4} a\left(1-e^{2}\right) R}\left[\left(\frac{5 e}{2} \cos \chi+2 \cos 2 \chi+\frac{e}{2} \cos \chi+e^{2}\right) \cos 2 \Phi\right. \\
& \left.+\left(\frac{5 e}{2} \sin \chi+2 \sin \chi+\frac{e}{2} \sin 3 \chi\right) \sin 2 \Phi+\left(e \cos \chi+e^{2}\right) \frac{\sin ^{2} \Theta}{1+\cos ^{2} \Theta}\right]
\end{aligned}
$$

ahol kihasználtuk, hogy $\Theta$ és $\Phi$ állandó (pl. a perihélium elfordulás figyelembevétele esetén $\dot{\Phi} \neq 0)$. Gyakran használják a polarizációs állapotokban az egyszerü körpálya limitet $(e=0)$, mellyel a $h_{\times}$és $h_{+}$lényegesen egyszerübb alakú lesz

$$
\begin{aligned}
& h_{\times}=-\frac{4 G^{2} \mu m \cos \Theta}{c^{4} a R} \sin \Psi, \\
& h_{+}=-\frac{2 G^{2} \mu m\left(1+\cos ^{2} \Theta\right)}{c^{4} a R} \cos \Psi,
\end{aligned}
$$

ahol $\Psi=\chi-\Phi$ fázis, amely a Kepler-egyenlet körpálya határátmenete alapján $\Psi=\omega t$, ahol $\omega$ a körpálya szögsebessége.

Az energia és az impulzusmomentum-veszteség megadható a kepleri pályákra, melyet Peters és Mathews származtatott ( [13], [14]) a ([3.47) és a ([3.42) kvadrupól-formulákból 1963-ban. A (3.44) kepleri momentumokat használva felírható az energia és az impulzus- 
momentum ${ }^{\square}$ nagyságának pillanatnyi vesztesége a $\chi$ valódia anomália függvényében

$$
\begin{aligned}
\frac{d E}{d t}= & -\frac{8 G^{4} \mu^{2} m^{3}}{15 c^{5} a^{5}\left(1-e^{2}\right)^{5}}\left[12(1+e \cos \chi)^{2}+e^{2} \sin ^{2} \chi\right](1+e \cos \chi)^{4} \\
\frac{d L}{d t}= & -\frac{8 G^{7 / 2} \mu^{2} m^{5 / 2}}{5 c^{5} a^{7 / 2}\left(1-e^{2}\right)^{7 / 2}}(4+10 e \cos \chi \\
& \left.+e^{2}\left(9 \cos ^{2} \chi-1\right)+e^{3} \cos \chi\left(3 \cos ^{2} \chi-1\right)\right)(1+e \cos \chi)^{2}
\end{aligned}
$$

melyeket átlagolva egy pálya periódusra megkapjuk az $E$ és $L$ dinamikai változók szekuláris veszteségeit

$$
\begin{aligned}
\left\langle\frac{d E}{d t}\right\rangle & =-\frac{32 G^{4} \mu^{2} m^{3}}{5 c^{5} a^{5}\left(1-e^{2}\right)^{7 / 2}}\left(1+\frac{73}{24} e^{2}+\frac{37}{96} e^{4}\right), \\
\left\langle\frac{d L}{d t}\right\rangle & =-\frac{32 G^{7 / 2} \mu^{2} m^{5 / 2}}{5 c^{5} a^{7 / 2}\left(1-e^{2}\right)^{2}}\left(1+\frac{7}{8} e^{2}\right) .
\end{aligned}
$$

A (B.53) és a (B.54) egyenletek baloldalán alkalmazva a kepleri összefüggéseket a dinamikai változók és a pályaelemek közt $\left(E=-G m \mu / 2 a, L^{2}=G m \mu^{2} a\left(1-e^{2}\right)\right)$, akkor a (3.5.3) és (B.54) veszteségek átírhatók a kepleri pálya geometriáját meghatározó pályaelemek veszteségeire

$$
\begin{aligned}
\left\langle\frac{d a}{d t}\right\rangle & =-\frac{64 G^{3} \mu m^{2}}{5 c^{5} a^{3}\left(1-e^{2}\right)^{2}}\left(1+\frac{73}{24} e^{2}+\frac{37}{96} e^{4}\right), \\
\left\langle\frac{d e}{d t}\right\rangle & =-\frac{304 G^{3} \mu m^{2}}{15 c^{5} a^{4}\left(1-e^{2}\right)^{5 / 2}} e\left(1+\frac{7}{8} e^{2}\right) .
\end{aligned}
$$

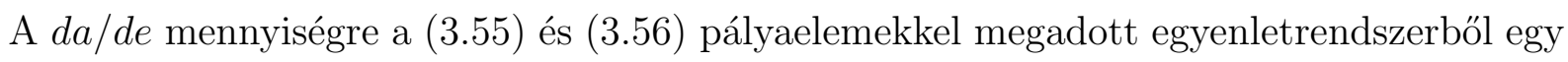
közönséges szétválasztható differenciálegyenlet képezhető, melynek megoldása az alábbi

$$
a(e)=C \frac{e^{12 / 19}}{1-e^{2}}\left(1+\frac{121}{304} e^{2}\right)^{870 / 2299}
$$

ahol $C$ egy tetszőleges állandó. A nulladrendű gravitációs sugárzási egyenletek (3.57) megoldása mutatja a pálya fél nagytengelyének és excentricitásának fokozatos csökkenését, melyből az következik, hogy a gravitációs sugárzás deformálja a pályát. Ezen sugárzási okok miatt a kettős spirálozó mozgást végez és az excentricitás csökkenése a pálya „,cirkularizációjához" vezet. Természetesen a két test fokozatos közeledésével a PN paraméter nagy lesz, mivel $\varepsilon$ arányos az $r^{-1}$ mennyiséggel. Emiatt meghatározható egy határ, amely közelében már nem alkalmazható a PN formalizmus, ez a határ az

\footnotetext{
${ }^{11} \mathrm{~A}(\mathbf{B . 4 2})$ alapján $d L / d t=\hat{\mathbf{L}} \cdot d \mathbf{L} / d t$ ismert, hogy kepleri pályákra a pálya-impulzusmomentumnak csak a 3 . komponense nem eltúnő $L_{z}=L$.
} 
ISCO (Innermost Stable Circular Orbit), a legbelső stabil körpálya sugara. A nem-forgó fekete lyuk körül egy próbarészecske legbelső stabil körpályájának sugara $r_{n f}=6 \mathrm{Gm} / \mathrm{c}^{2}$, neutroncsillagokra ez a sugár az állapotegyenletük alapján számolható. A kompakt kettős rendszerek hullámalakjainak számolásához az ISCO-ra az $r_{n f}$-et használják.

\subsection{A gravitációs hullámok mérése}

A jelenleg működő földi interferometrikus detektorok a LIGO, Virgo, GEO és TAMA, melyek Fabry-Perot interferométerek, melyekkel a fény útja a fizikai karhosszakban megtöbbszörözhető, melyhez nagy teljesítményü és kellő stabilitású lézert használnak. A kezdeti lézernyalábot egy osztótükör segítségével szétbontják, majd a karok végén lévő tükrök visszaverődése után ismét egyesítik őket. A kialakult interferenciaképben állandó kioltást állítanak be, de amikor egy gravitációs hullám áthalad az interferométeren, akkor a detektor karjainak hosszai megváltoznak, amely elrontja az előzőleg beállított kioltást, melyet a karok végén lévő tükrök mozgatásával folyamatosan korrigálnak, tehát a gravitációs hullámokra a tükrök elmozdulásából lehet következtetni. Az asztrofizikai forrásokból kapható hullámhossz $5 \mathrm{~km}$, vagy nagyobb, ezért a földi detektorok méretei alkalmasak a detektáláshoz.

A detektor karjainak deformációjából származó kicsiny $\delta x^{\alpha}$ távolságkülönbséget a geodetikus vonalak elhajlásának egyenletéből lehet meghatározni. Egymáshoz közel lévő próbatestek relatív elmozdulásának mértékét a Riemann-tenzorral mérhetjük [40]. A linearizált egyenletekből következik, hogy $\partial^{2} h_{\alpha \beta}^{T T} / \partial t^{2}=2 R_{\alpha 0 \beta 0}$, vagyis

$$
\frac{d^{2} \delta x^{\alpha}}{d t^{2}}=-R_{\alpha 0 \beta 0} x^{\beta}=\frac{1}{2} \frac{\partial^{2} h_{\alpha \beta}^{T T}}{\partial t^{2}} x^{\beta} .
$$

Ezen egyenletet kétszer integrálva (mivel a $\delta x^{\alpha}$ távolságkülönbség ,,kicsiny”, így a jobboldalon lévő $x^{\beta}$ állandónak tekinthető) megkapjuk, hogy a távolságkülönbség arányos a gravitációs hullámalakkal

$$
\delta x^{\alpha}=\frac{1}{2} h_{\alpha \beta}^{T T} x^{\beta} .
$$

Ebből látható, hogy a $h_{\alpha \beta}^{T T}$ dimenziótlan és a detektor relatív úthosszkülönbségével $(d L / L)$ azonosítható, tehát

$$
h=\frac{2 d L}{L} .
$$

LIGO detektor esetén a $d L / L \sim 10^{-22}$, amely frekvenciafüggő. A (B.3.9) kvadrupólformula alapján megbecsülhető a gravitációs hullám ampitudója egy 300 millió fényévre 
(kb. 100Gpc) lévő forrásra

$$
h=\frac{2 G E_{Q}}{c^{4} R} \simeq 10^{-21}\left(\frac{E_{Q}}{M_{\odot} c^{2}}\right)\left(\frac{100 G p c}{R}\right)
$$

ahol bevezetésre került az $E_{Q}=d^{2} I^{\alpha \beta} / d t^{2}$,nem-gömbi mozgási energia”, amely a kvadrupólmomentumok deformációja miatt nevezhető így. Egy kettős rendszer kepleri pályájára az $E_{Q} \simeq 2 G m \mu / a$, amely a (‥44) kvadrupól-komponensekből adódik. Így a $7.1 k p c$-re lévő Hulse Taylor pulzárra az amplitúdó $h \simeq 4.0 \times 10^{-23}$, míg a $0.5 k p c$ re lévő J0737-3039-re $h \simeq 1.0 \times 10^{-21}$ (ez utóbbi kettős pulzár éppen a LISA detektor várható érzékenységi görbéje közelébe esik, amely a $2.2 \times 10^{-4} \mathrm{~Hz}$ frekvencián található). A detektorok frekvencia tartománya LIGO-ra $(10$ - 1000) Hz, Virgo-ra $(10-500) H z$ és a jövőben épülő LISA detektorra $\left(10^{-5}-1\right) H z$ (5. ábra). A pulzárok és a naptömegü fekete lyuk kettősök spirálozása a LIGO és a Virgo, míg a szupermasszív fekete lyukak összeolvadása a LISA detektorok mérhető tartományába esik. A PTA rendszerrel feltehetően $\left(10^{-9}-10^{-6}\right) H z$ frekvencia tartományba eső források mérhetők majd.

A detektor a hullámalakot $(h)$ a zajjal $(n)$ együtt méri

$$
s=h+n,
$$

amiből a tiszta jelet adatanalízis módszerekkel lehet leválasztani. A detektorok zajfüggvénye jól ismert, melyet legtöbbször a tükrök kvantumzaja limitál (5. ábra). A gravitációs hullám a két polarizációs állapotot az úgynevezett $F_{+}$és $F_{\times}$antenna függvényekkel együtt tartalmazza

$$
h=F_{+} h_{+}+F_{\times} h_{\times} .
$$

Az $F_{+, \times}$antennafüggvények a forrás és a detektor pozícióját úgy transzformálják, hogy a gravitációs hullámokra teljesüljön a TT-mérték. Egy asztrofizikai forrás leíráshoz szükséges négy független szögmennyiség, a forrás $\mathbf{L}_{N}$ pálya-impulzusmomentuma $\left(\Theta_{L}\right.$ és $\left.\Phi_{L}\right)$ és a forrás helyzete $\left(\Theta_{S}, \Phi_{S}\right)$ a detektor rendszerében. Fontos megjegyezni, hogy spinek figyelembevétele esetén a négy független szög időfüggővé válhat (pl. a spinprecesszió figyelembevételével $\widehat{\mathbf{L}}_{N}$ nem mozgásállandó [48]). A LISA detektor nap körüli mozgása miatt a szögek kepleri esetben (spinek nélkül) is időfüggőek lesznek.

Az antenna függvényeknél egy $\psi$ polarizációs szöget használnak, amely egyszerüsíti a hullámalakot, valamint a felénk érkező hullámok rendszerében a hullámfront helyzetét 


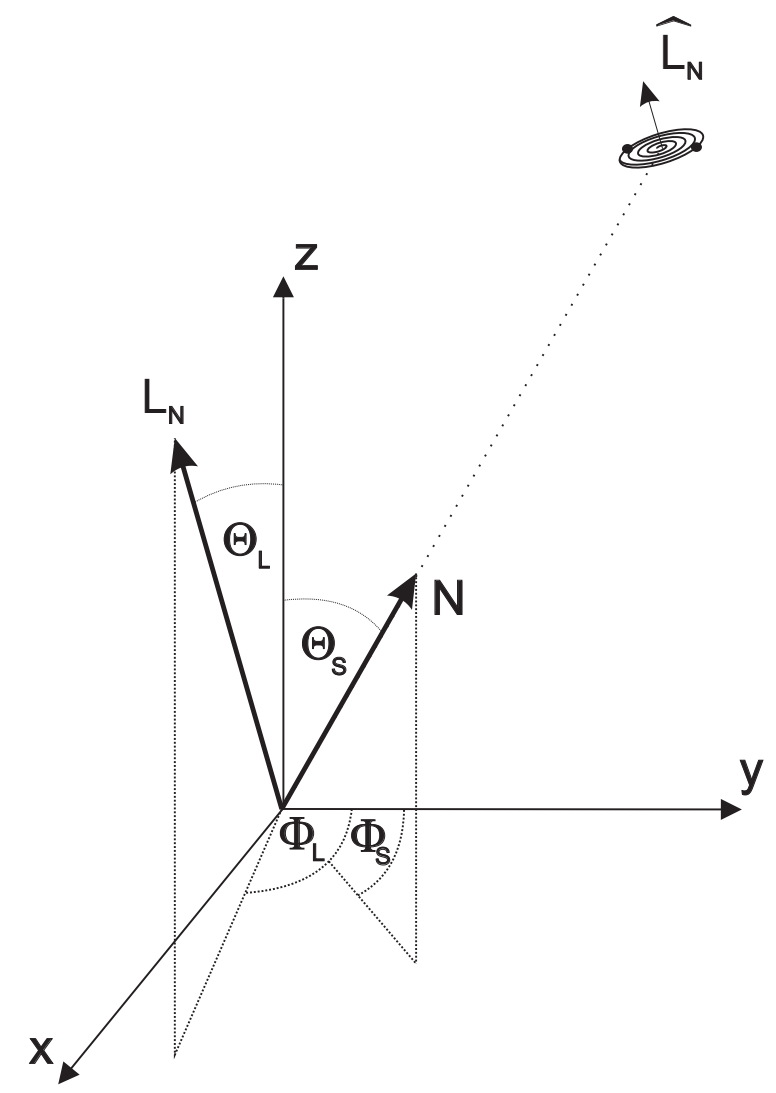

4. ábra. Kompakt kettős a detektorhoz rögzített koordinátarendszerben.

adja meg. Az $F_{+\times}$alakjai a $\psi$ polarizációs szöggel

$$
\begin{aligned}
& F_{+}=2^{-1}\left(1+\cos ^{2} \Theta_{S}\right) \cos \left(2 \Phi_{S}\right) \cos (2 \psi)-\cos \Theta_{S} \sin \left(2 \Phi_{S}\right) \sin (2 \psi), \\
& F_{\times}=2^{-1}\left(1+\cos ^{2} \Theta_{S}\right) \cos \left(2 \Phi_{S}\right) \sin (2 \psi)+\cos \Theta_{S} \sin \left(2 \Phi_{S}\right) \cos (2 \psi),
\end{aligned}
$$

ahol $\Theta_{S}, \Phi_{S}$ a forrás polárszögei és a $\psi$ polarizációs szög [49.]

$$
\tan \psi=\frac{\left(\widehat{\mathbf{L}}_{N} \cdot \widehat{\mathbf{z}}\right)-\left(\widehat{\mathbf{L}}_{N} \cdot \widehat{\mathbf{N}}\right)(\widehat{\mathbf{N}} \cdot \widehat{\mathbf{z}})}{\widehat{\mathbf{N}} \cdot\left(\widehat{\mathbf{L}}_{N} \times \widehat{\mathbf{z}}\right)}
$$

ahol $\widehat{\mathbf{L}}_{N}$ a pálya-impulzusmomentum, a $\widehat{\mathbf{z}}$ az interferometrikus detektor síkjára merőleges és $\widehat{\mathbf{N}}$ a detektorból a forrásba mutató egységvektorok (甘木. ábra)(LISA-nál az antennafüggvények időfüggőek [50]]). Tehát magasabb rendű korrekciók nélkül a polarizációs szög a következő alakú (四. ábra)

$$
\tan \psi=\frac{\cos \Theta_{L}-\cos \Theta_{S}\left(\sin \Theta_{L} \sin \Theta_{S} \cos \left(\Phi_{S}-\Phi_{L}\right)+\cos \Theta_{L} \cos \Theta_{S}\right)}{\sin \Theta_{L} \sin \Theta_{S} \sin \left(\Phi_{S}+\Phi_{L}\right)}
$$


Spinek jelenlétében a gravitációs hullámalakok meghatározása nehezen kivitelezhető. Általában körpálya esetben szokták vizsgálni a spinek okozta változásokat hullámalakokban, melyekkel egyszerű becsléseket lehet tenni az egyes paraméterek hibáira [5]].

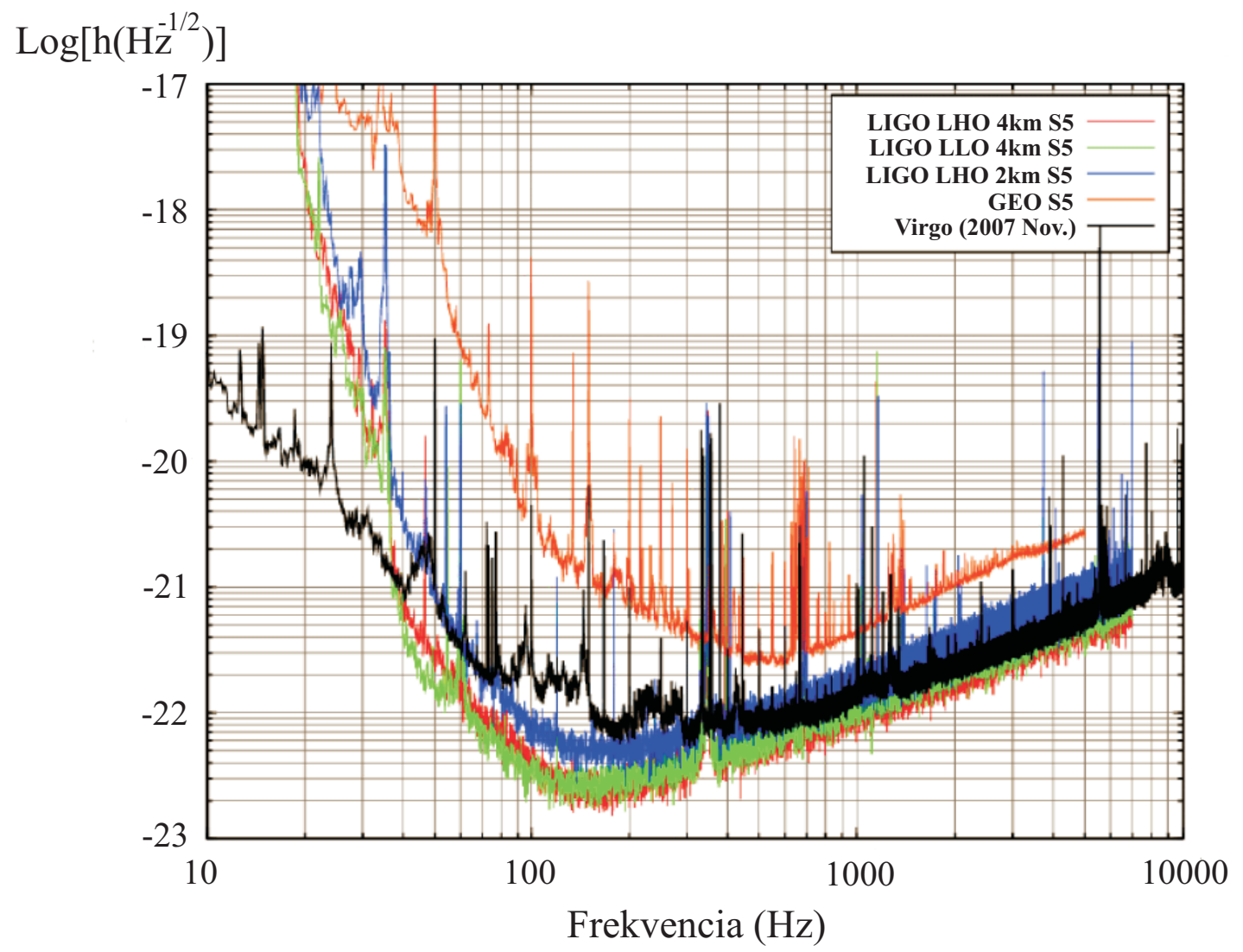

5. ábra. A jelenleg müködő (2010) interferometrikus detektorok érzékenységi görbéi $\left(S_{n}\right.$ zajfüggvényei) a frekvencia függvényében. Az LHO Hanford és az LLO Livingston közelében lévő LIGO detektorokat jelöli (Az LHO 4km-es detektor mellett, egy $2 k m$-es detektor is müködik). Az ábrán látható érzékenységi görbék alapján a LIGO $(30-2000) H z$, a Virgo pedig az alacsonyabb (10-40) Hz frekvencia tartományban érzékenyebb.

A gravitációs hullámalakok adatanalízisére szolgáló módszer a Fisher mátrixokon alapuló paraméterbecslés. Ennek lényege, hogy a (3.63) $h$ hullámalakban szereplő paraméterek hibájára az ún. Cramér-Rao reláció-ból következtethetünk ${ }^{\mathbb{W}}$. Általában a paraméterek becslése frekvenciatérben történik, mivel a detektor $S_{n}(F)$ zajfüggvényét is közvetlenül a frekvenciában határozzák meg. A hullámalakok frekvencia előállítása analitikus esetben a stacionárius fázis közelítéssel (stationary phase approximation, SPA) adható meg. Például a (3.49) és a (3.50) körpályás hullámalakot tekintve, melyek Kepler 3. törvénye alapján $\left(n^{2} a^{3}=G M\right.$, ahol $n=2 \pi \nu$ a középmozgás, és $\nu$ a pályafrekvencia) a

\footnotetext{
${ }^{12}$ A Cramér-Rao reláció tulajdonképpen egy $n$ számú $\lambda_{i}$ paramétert tartalmazó mintában $\left(h\left(\lambda_{i}\right)\right)$ lévő egyes paraméterek szórásának $\left(\Delta \lambda_{i}\right)$ az alsó határát adja meg, amelyet a Fisher-mátrixokból adható meg. [52].
} 
$\nu$ pályafrekvenciával adhatók meg

$$
\begin{aligned}
& h_{\times}=-\frac{4(G \mathcal{M})^{5 / 3} \cos \Theta(2 \pi \nu)^{2 / 3}}{c^{4} R} \sin \Psi, \\
& h_{+}=-\frac{2(G \mathcal{M})^{5 / 3}\left(1+\cos ^{2} \Theta\right)(2 \pi \nu)^{2 / 3}}{c^{4} R} \cos \Psi,
\end{aligned}
$$

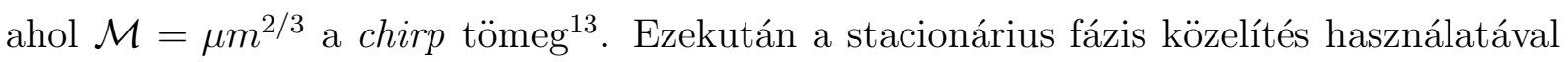
a (‥67) és a (‥68) hullámalakok átírhatók az $F$ frekvenciatérben érvényes alakra ${ }^{\mathbb{4}}$

$$
\begin{aligned}
\widetilde{h_{\times}(F)} & =-2 \sqrt{\frac{5}{96}} \frac{\mathcal{M}^{5 / 6} \pi^{-2 / 3} F^{-7 / 6}}{R} \cos \Theta e^{i \Psi^{+}}, \\
\widetilde{h_{+}(F)} & =-\sqrt{\frac{5}{96}} \frac{\mathcal{M}^{5 / 6} \pi^{-2 / 3} F^{-7 / 6}}{R}\left(1+\cos ^{2} \Theta\right) e^{i \Psi^{-}}
\end{aligned}
$$

ahol $\Psi^{ \pm}=2 \pi F t_{c}-\phi_{c} \pm \pi / 4+(3 / 4)(8 \pi \mathcal{M} F)^{-5 / 3}$, valamint $t_{c}$, és $\phi_{c}$ az ,,összeolvadáshoz" tartozó idő és fázis, melyek a (3.5.5) egyenlet integrálásából adódó állandók. Ezen kepleri körpálya esetén látható, hogy a $h$ teljes hullámalak 10 paramétert $\left(\mathcal{M}, R, t_{c}, \phi_{c}, \Theta_{S}\right.$, $\Phi_{S}, \Theta_{L}$ és $\Phi_{L}$ ) tartalmaz (a spinek és az excentricitás figyelembevételével ez 16 dimenziós paramétertérre bővül [5:3]). A paraméterek becslésére szolgáló Fisher mátrix definíciója a következő

$$
\Gamma_{a b}=2 \int_{0}^{\infty} \frac{h_{, a}(F) h_{, b}^{*}(F)+h_{, b}(F) h_{, a}^{*}(F)}{S_{n}(F)} d F,
$$

ahol $S_{n}(F)$ a detektor zajfüggvénye (5. ábra), $h_{, a}(F)=\partial h(F) / \partial \lambda_{a}$ az egyes paraméterek szerinti parciális deriváltat jelöli és $h^{*}$ a $h$-nak a komplex konjugáltja. A Fisher mátrix inverze a $\Sigma=(\Gamma)^{-1}$ kovariancia mátrix, melynek diagonális elemeiből megkapjuk az egyes paraméterek szórását $\left(\Delta \lambda_{a}=\sqrt{\Sigma_{a a}}\right)$, a többi komponenseiből, pedig az egyes paraméterek közti korrelációkat számolhatjuk ki $\left(c_{a b}=\Sigma_{a b}\left(\Sigma_{a b} \Sigma_{b b}\right)^{-1 / 2}\right)$.

Ezen adatanalízis módszert először Finn és Chernoff alkalmazta perturbált fekete lyukakra [54], [55], melyet a gravitációs hullámok adatanalízisében előszeretettel használnak [50], [51], [56]], [57] és [58].

\footnotetext{
${ }^{13}$ Látható, hogy a hullámalak amplitudójában egyféle tömegkombináció $\left(\mu m^{2 / 3}\right)$ jelenik meg, így célszerüvé vált az $\mathcal{M}$ chirp tömeg bevezetése.

${ }^{14}$ A stacionárius fázis közelítés a következő: $\left.\int_{-\infty}^{\infty} h[\nu(t)] e^{i g(t)} d t \simeq \sqrt{\frac{2 \pi}{\tilde{g}\left(t_{0}\right)}} h(\nu)\right] e^{i\left(g\left(t_{0}\right)+\pi / 4\right)}$, ahol $g(t)$ egy tetszőleges időfüggő függvény, $h[\nu(t)]$ egy időben lassan változó függvény (a $\nu$ pályafrekvencia polinomja) és $\nu=\nu\left(t_{0}\right), g\left(t_{0}\right)$ a a $t_{0}$ nyeregpontban felvett értékek (a $t_{0}$ nyeregpont a $\dot{g}\left(t_{0}\right)=0$-ból határozható meg).
} 


\section{Poszt-newtoni formalizmus}

$\mathrm{Az}$ általános relativitáselméletben az összemérhető tömegü kétpontrendszerek mozgásegyenletét Einstein, Infeld és Hoffmann (továbbiakban EIH) [15], valamint Eddington és Clark [5.9] származtatta elöször 1938-ban, majd ezen egyenletek integrálásából Robertson megmutatta a perihélium elfordulást [60], amely 1 PN rendű relativisztikus effektusnak számít. Az EIH-egyenletek gömbszimmetrikus nemforgó testeket írnak le, amelyek szinguláris monopólokként jelennek meg az energia impulzustenzorban.

A fejezetben röviden áttekintem a PN sorfejtés alapjait a [6]] irodalmat követve, majd vázlatosan megmutatom a mozgásegyenletek PN formalizmusból történő származtatását.

A PN közelítés, tulajdonképpen egy olyan gyengetér közelítése az általános relativitáselméletnek, melynél a mozgó testek pontszerűek és a fénysebességhez képest lassan mozognak. Ezáltal a PN formalizmus az általános relativitáselmélet egy sorfejtése, amelyben, a sorfejtési kisparaméter definíciója az alábbi

$$
\lambda=\left(\frac{G m}{c^{2} r}\right)^{1 / 2} \simeq \frac{v}{c},
$$

melynek a négyzete a $\mathrm{PN}$ paraméter $\left(\varepsilon=\lambda^{2}\right)$. Erre példaként említhető a fényelhajlás $\left(\Delta \phi=4 G m / b c^{2}\right)$, amely $1 \mathrm{PN}$ (vagy $\varepsilon$ vagy $\left.\lambda^{2}\right)$ rendü effektus. Történeti okok miatt először $\lambda$-t vezették be és utána az $\varepsilon$-t ( $\lambda$ használata esetén nincsenek ,,feles” rendű tagok, ellentétben az $\varepsilon$ PN paraméterben).

A $\lambda$ kis paraméter szerint, sorbafejthető a metrika, melynek komponensei $(\llbracket 5)$ :

$$
\begin{aligned}
g_{00} & =-1+\stackrel{2}{g}_{00}+\stackrel{4}{g}_{00}+\ldots \\
g_{\alpha 0} & =\stackrel{3}{g}_{\alpha 0}+\stackrel{5}{g}_{\alpha 0}+\ldots \\
g_{\alpha \beta} & =\stackrel{2}{g}_{\alpha \beta}+\stackrel{4}{g}_{\alpha \beta}+\stackrel{g}{\alpha \beta}+\ldots
\end{aligned}
$$

ahol a $\stackrel{N}{g}_{a b}$ jelöli a $\lambda^{N}$ kis paraméterrel arányos tagokat. A $g_{a b}$ metrika legalacsonyabb rendü tagjainak meg kell egyezniük az általános relativitáselmélet newtoni határátmenetéből kapott metrika komponenseivel, vagyis $\stackrel{2}{g}_{00}=2 \phi$ és $\stackrel{2}{g}_{\alpha \beta}=2 \phi \delta_{\alpha \beta}$, ahol $\phi=-G m / r$ a newtoni gravitációs potenciál. Ha az 1 PN rendet tartalmazó mozgásegyenletet akarjuk származtatni, akkor a $g_{00}$-ban $\mathcal{O}\left(\lambda^{4}\right)$, a $g_{a 0}$-ban $\mathcal{O}\left(\lambda^{3}\right)$ és a $g_{a b}$-ban $\mathcal{O}\left(\lambda^{0}\right)$ rendekig kell figyelembe venni a tagokat. Hosszas és fáradtságos számolások után belátható, hogy a (42) metrikából számolt Ricci-tenzor komponensei hasonló struktúrát mutatnak, mint

\footnotetext{
${ }^{15}$ Amely az időtükrözési szimmetria megkövetelése miatt, a $g_{\alpha 0}$ komponensekre előjelet vált, míg $g_{00}$ és $g_{\alpha \beta}$-ra nem vált előjelet. Ezért $g_{00}, g_{\alpha \beta}$-ra $N$ páros, míg $g_{\alpha 0}$-ra $N$ páratlan. Hasonló okokból igaz a $R_{a b}$ és $T_{a b}$ tenzorokra.
} 
a $g_{a b}$ metrikánál, melyek a rendeket tekintve az alábbiak lesznek

$$
\begin{aligned}
& R_{00}=\stackrel{2}{R}_{00}+\stackrel{4}{R}_{00}+\ldots, \\
& R_{\alpha 0}=\stackrel{3}{R}_{\alpha 0}+\stackrel{5}{R}_{\alpha 0}+\ldots, \\
& R_{\alpha \beta}=\stackrel{2}{R}_{\alpha \beta}+\stackrel{4}{h}_{\alpha \beta}+\ldots,
\end{aligned}
$$

ahol $\stackrel{N}{R}$ ab Ricci-tenzor $\mathcal{O}\left(\lambda^{N} / r^{2}\right)$ rendü. A harmonikus (vagy de Donder) koordinátafeltétel a következő (ez azért célszerü, mert az $R_{00}$ komponensekből a $h_{\alpha 0}$ tartalmazó tagok eltüntethetők)

$$
\nabla_{a}\left(\sqrt{g} g^{a b}\right)=0
$$

amelyben egyszerúbb alakúak lesznek a mozgásegyenletek. Az ilyen mértékben felírt koordinátákat harmonikus koordináták-nak nevezzük. Az irodalomban használják még az ADM-koordinátákat is, amellyel elérhető, hogy a mozgásegyenletek magasabb rendü járulékai ne tartalmazzanak gyorsulást [62] (például a harmonikus koordinátákban felírt kettős 2 PN rendü Lagrange-függvénye gyorsulásfüggő, míg az ADM-koordinátákban nem). Belátható, hogy a (4.4) feltétel ekvivalens a következő összefüggéssel

$$
g^{a b} \Gamma_{a b}^{c}=0
$$

Ezt a (4.5) harmonikus feltételt alkalmazva a (4.2) metrikára, a következő feltételt kapjuk a $\lambda^{2}$-el arányos tagokra

$$
\frac{\partial g_{00}^{2}}{\partial x^{\alpha}}-2 \frac{\partial g_{\alpha \beta}}{\partial x^{\beta}}+\frac{\partial \stackrel{2}{g}_{\beta \beta}}{\partial x^{\alpha}}=0
$$

és a $\lambda^{3}$-el arányos tagokra $(\partial / \partial t \sim \lambda)$

$$
\frac{\partial^{2}}{\partial t}-2 \frac{\partial \stackrel{3}{g}_{0 \beta}}{\partial x^{\beta}}+\frac{\partial \stackrel{2}{g}_{\alpha \beta}}{\partial t}=0 .
$$

Ezek után az Einstein-egyenletek kapcsán megmutatható, hogy az energia-impulzus tenzor struktúrája a (4-3) egyenletek felhasználásával a következő"m

$$
\begin{aligned}
& T_{00}=\stackrel{0}{T}_{00}+\stackrel{2}{T}_{00}+\ldots, \\
& T_{\alpha 0}=\stackrel{1}{T}_{\alpha 0}+\stackrel{3}{T}_{\alpha 0}+\ldots, \\
& T_{\alpha \beta}=\stackrel{2}{T}_{\alpha \beta}+\stackrel{4}{T}_{\alpha \beta}+\ldots,
\end{aligned}
$$

\footnotetext{
${ }^{16} \mathrm{Az}$ Einstein-egyenletek spúrképzéséből kapható $R_{a b}=\frac{8 \pi G}{c^{4}}\left(T_{a b}-\frac{1}{2} g_{a b} T\right)$ egyenletből származtathatók az egyes rendek. ( $T$ a $T_{a b}$ tenzor spúrja).
} 
ahol $\stackrel{N}{T}_{a b}$ tenzor a $\left(m / r^{3}\right) \lambda^{N}$-el arányos mennyiség. Ezek után a (4.3) és a (4.8) mennyiségek segítségével felírhatók az Einstein-egyenletek, melyek a (4.4) harmonikus koordinátákban a következők

$$
\begin{aligned}
\nabla^{2} g_{00} & =\frac{8 \pi G}{c^{4}} T^{00} \\
\nabla^{2} g_{00} & =\frac{\partial^{2} g_{00}}{\partial t^{2}}+\stackrel{2}{g}_{a b} \frac{\partial^{2} g_{00}}{\partial x^{a} \partial x^{b}}-\frac{\partial g_{00}^{2}}{\partial x^{\alpha}} \frac{\partial^{2}}{\partial x_{00}}+\frac{8 \pi G}{c^{4}}\left(\stackrel{2}{T^{00}}-2 \stackrel{2}{g_{00}} T^{00}+T^{a a}\right) \\
\nabla^{2} g_{\alpha 0} & =-\frac{16 \pi G}{c^{4}} T^{\alpha 0} \\
\nabla^{2} g_{\alpha \beta} & =\frac{8 \pi G}{c^{4}} \delta_{\alpha \beta} T^{00}
\end{aligned}
$$

Látható, hogy a (4.9) egyenletben a $\stackrel{2}{g}_{00}=2 \phi$ a newtoni potenciál, amely a Poissonegyenletnek felel meg és a (4.J2) egyenletben a $g_{\alpha \beta}^{2}=2 \phi \delta_{\alpha \beta}$. Bevezethető még egy $\zeta_{\alpha}$ vektor- és $\psi$ skalár-potenciálok a $g_{\alpha 0}^{3}=\zeta_{\alpha}$ és $g_{00}^{4}=-2 \phi^{2}-2 \psi$ definíciókból. A (4.6) koordináta-feltétel az előző jelölésekkel egyszerűen felírható

$$
4 \frac{\partial \phi}{\partial t}-\nabla_{a} \zeta^{a}=0
$$

A továbbiakban megadhatók a Christoffel-szimbólumok a fentiekben bevezetett $\phi, \psi$ és $\zeta_{\alpha}$ potenciálokkal, melyekből a geodetikus-egyenletet felhasználva felírható a próbarészecske mozgásegyenlete

$$
\frac{d \mathbf{v}}{d t}=-\nabla\left(\phi+2 \phi^{2}+\psi\right)-\frac{\partial \zeta}{\partial t}+\mathbf{v} \times(\nabla \times \zeta)+3 \mathbf{v} \frac{\partial \phi}{\partial t}+4 \mathbf{v}(v \cdot \nabla) \phi-v^{2} \nabla \phi
$$

Ezen mozgásegyenletből, valamint a $\phi, \psi$ és $\zeta_{\alpha}$ vezetőrendü járulékaiból felírható az első PN rendü gyorsulás (5.6).

\subsection{Mozgásegyenletek származtatása a metrikából (1 PN)}

Feltesszük, hogy a linearizált metrika komponensei $h_{00}=2 \Phi / c^{2}, h_{\alpha 0}=0$ és $h_{\alpha \beta}=$ $2 \Phi \delta_{\alpha \beta} / c^{2}$, ahol $\Phi=-G m_{p} /\left|\mathbf{r}-\mathbf{r}_{p}\right|$ a pontszerü testek newtoni potenciálja, valamint $\mathbf{r}_{p}$ a $p$-ik részecske helyvektorát jelöli. A pontszerü testek energia-impulzus tenzorát a következőképpen írhatjuk fel

$$
T_{a b}=\sum_{p} \frac{m_{p} c}{\sqrt{-g}} \frac{d x^{a}}{d s} \frac{d x^{b}}{d t} d\left(\mathbf{r}-\mathbf{r}_{p}\right)
$$


Ekkor a (4.2) metrika felhasználásával a (4.15) energia-impulzus tenzor komponensei az alábbiak

$$
\begin{aligned}
T_{00} & =\sum_{p} m_{p} c^{2}\left(1+\frac{5 \Phi_{p}}{c^{2}}+\frac{v_{p}^{2}}{2 c^{2}}\right) d\left(\mathbf{r}-\mathbf{r}_{p}\right), \\
T_{\alpha 0} & =-\sum_{p} m_{p} c\left(v_{p}\right)_{\alpha} d\left(\mathbf{r}-\mathbf{r}_{p}\right), \\
T_{\alpha \beta} & =-\sum_{p} m_{p}\left(v_{p}\right)_{\alpha}\left(v_{p}\right)_{\beta} d\left(\mathbf{r}-\mathbf{r}_{p}\right),
\end{aligned}
$$

ahol bevezetésre kerültek a $d x^{\alpha} / d t=v^{\alpha}$ négyessebesség és a $\Phi_{p}=\Phi\left(\mathbf{r}_{p}\right)$ jelölések. A (4.3) Ricci-tenzor explicit alakját használva megkaphatók a metrika következő rendü $\mathcal{O}\left(1 / c^{4}\right)$ komponensei

$$
\begin{aligned}
g_{00} & =-1+\frac{2 \Phi}{c^{2}}-\frac{1}{c^{4}}\left[2 \Phi+\sum_{p} \frac{G m_{p}}{\left|\mathbf{r}-\mathbf{r}_{p}\right|}\left(2 \bar{\Phi}_{p}+3 v_{p}^{2}\right)\right]+\ldots, \\
g_{\alpha 0} & =\frac{G}{c^{3}} \sum_{p} \frac{m_{p}}{\left|\mathbf{r}-\mathbf{r}_{p}\right|}\left[7\left(v_{p}\right)_{\alpha}+\left(\mathbf{v}_{p} \mathbf{n}_{p}\right)\left(n_{a}\right)_{\alpha}\right]+\ldots, \\
g_{\alpha \beta} & =1+\frac{2 \Phi \delta_{\alpha \beta}}{c^{2}}+\ldots,
\end{aligned}
$$

ahol $\bar{\Phi}_{p}=-\sum_{q, q \neq p} m_{q} /\left|\mathbf{r}_{p}-\mathbf{r}_{q}\right|$ és $\mathbf{n}_{p}=\left(\mathbf{r}-\mathbf{r}_{p}\right) /\left|\mathbf{r}-\mathbf{r}_{p}\right|$ egységvektor. Ezek után meghatározható a $p$-edik mozgó részecske $\mathcal{L}_{p}$ Lagrange-függvénye a többi részecske által keltett gravitációs térben, amely az $\mathcal{L}_{p}=-m_{p} c(d s / d t)$ egyenlet alapján kapható meg, amelyben a $d s / d t$ a részecske sebessége, tehát

$$
\mathcal{L}_{p}=-m_{p} c^{2}\left(1+h_{00}+2 h_{\alpha 0} \frac{v_{p}^{\alpha}}{c}-\frac{v_{p}^{\alpha}}{c^{2}}+h_{\alpha \beta} \frac{v_{p}^{\alpha} v_{p}^{\beta}}{c^{2}}\right)^{1 / 2}
$$

Ismert, hogy az $m_{p}$ pontrendszer teljes $\mathcal{L}$ Lagrange-függvénye nem azonos a részecskék Lagrange-függvényeinek összegével $\left(\sum_{p} \mathcal{L}_{p}\right)$. Emiatt először elő kell állítani az egyes $m_{p}$ tömegü részecskére ható $\mathbf{f}_{p}$ erőket az $\mathbf{f}_{p}=\left(\partial \mathcal{L}_{p} / \partial \mathbf{r}\right)\left(\mathbf{r}=\mathbf{r}_{p}\right)$ egyenlet alapján, s ezen erőrendszerhez kell meghatározni a globális $\mathcal{L}$ Lagrange-függvényt. A végeredmény a következő

$$
\begin{aligned}
\mathcal{L}= & \sum_{p} \frac{m_{p} v_{p}^{2}}{2}+\sum_{\substack{p, q \\
p \neq q}} \frac{G m_{p} m_{q}}{2 r_{p q}}+\sum_{\substack{p, q \\
p \neq q}} \frac{3 G m_{p} m_{q} v_{p}^{2}}{2 c^{2} r_{p q}}+\sum_{p} \frac{m_{p} v_{p}^{4}}{8 c^{2}} \\
& -\sum_{\substack{p, q \\
p \neq q}} \frac{G m_{p} m_{q}}{4 c^{2} r_{p q}}\left[7\left(\mathbf{v}_{p} \mathbf{v}_{q}\right)+\left(\mathbf{v}_{p} \mathbf{n}_{p q}\right)\left(\mathbf{v}_{q} \mathbf{n}_{p q}\right)\right]-\sum_{\substack{p, q, k \\
p \neq q, p \neq k}} \frac{3 G^{2} m_{p} m_{q} m_{k}}{2 c^{2} r_{p q} r_{p k}}
\end{aligned}
$$


ahol $r_{p q}=\left|\mathbf{r}_{p}-\mathbf{r}_{q}\right|$ és $\mathbf{n}_{p q}=\left(\mathbf{r}_{p}-\mathbf{r}_{q}\right) /\left|\mathbf{r}_{p}-\mathbf{r}_{q}\right|$ bevezetett mennyiségek. Az első két tag a

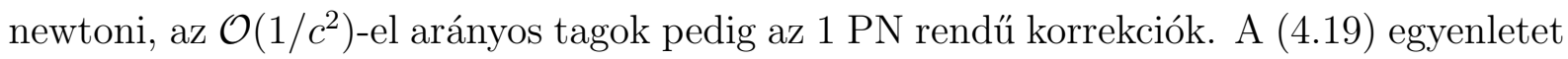
alkalmazva $m_{1}$ és $m_{2}$ tömegpontokra a Lagrange függvény a következő alakú

$$
\begin{aligned}
\mathcal{L}_{m_{1}, m_{2}}= & \frac{m_{1} v_{1}^{2}}{2}+\frac{m_{1} v_{2}^{2}}{2}+\frac{G m_{1} m_{2}}{r}+\frac{m_{1} v_{1}^{4}+m_{2} v_{2}^{4}}{8 c^{2}}+\frac{G m_{1} m_{2}}{2 c^{2} r} \\
& \times\left[3\left(v_{1}^{2}+v_{2}^{2}\right)-7\left(\mathbf{v}_{1} \mathbf{v}_{2}\right)-\left(\mathbf{v}_{1} \mathbf{n}\right)\left(\mathbf{v}_{2} \mathbf{n}\right)-\frac{3 G\left(m_{1}+m_{2}\right)}{r}\right],
\end{aligned}
$$

ahol $r=r_{12}$ a relatív távolságkülönbsége a két testnek. A (4.20) Lagrange-függvény tömegközépponti rendszerben relatív koordinátákkal $\left(\mathbf{v}=\mathbf{v}_{2}-\mathbf{v}_{1}, m=m_{1}+m_{2}, \mu=\right.$ $\left.m_{1} m_{1} / m\right)$ egycentrum-problémaként is felírható.

Kompakt kettősök 1 PN rendű Lagrange-függvényből elsőként Damour és Deruelle adta meg a mozgás leírását 1985-ben [17]. Lagrange-formalizmus alapján 1 PN esetben megmutatható, hogy a radiális és a szögrész szétcsatolódik, vagyis $\dot{r}^{2}=A+B / r+C / r^{2}+$ $D / r^{3}$ és $\dot{\theta}=I / r^{2}+H / r^{3}$ (ahol $A-D, I, H$ állandók, melyek közül $A, B, C$ és $I$ tartalmaz kepleri járulékot is a lineáris pertubáción kívül és $r$ és $\theta$ a radiális és polár koordináta). Damour és Deruelle leírásában a conchoidális transzformációt használták, mellyel az 1 PN rendű tagokat , kitranszformálták” a radiális és szögegyenletekből, vagyis a $D$ és $H$ „,tiszta” perturbációs állandókat eltűntették és így formálisan kepleri alakú egyenleteket kaptak, melyből az általuk bevezetett ,,kvázikepleri” paraméterezéssel megadhatóvá vált a mozgás. Érdekes megemlíteni, hogy a leírásukban 3-féle excentricitás $\left(e_{R}\right.$ radiális-, $e_{T}$, idő-, $e_{\theta}$, szög-excentricitás) szerepel. Az elnevezések arra utalnak, hogy mely 1 PN rendü egyenletekben szerepelnek, ( $e_{R}$ a paraméterezés definíciójában, $e_{T}$ a Kepler-egyenletben és $e_{\theta}$ a szögegyenletből kapható ,,szögmozgásnál”) melyek kepleri esetben azonosak a nulladrendü excentricitással ${ }^{\square]}$.

A perturbálatlan Kepler-egyenletnek nem létezik zárt alakban felírható megoldása a transzcendens tulajdonsága miatt, ezért az égi mechanikában jól ismert Fourier-Bessel sorfejtés segítségével írható fel a megoldása sor alakban. Ezzel a sorfejtéssel adható meg az explicit radiális mozgás időbeli fejlődése ( [혀] $]$ ).

\subsection{Mozgásegyenletek származtatása a dinamikai-egyenletből}

A testek mozgásegyenleteinek származtatását az általános relativitáselméletben két irányból közelítik meg. Az egyik a fentebb bemutatott PN formalizmus (Einstein, Infeld és Hoffmann), az Einstein-egyenleteket használja összemérhető tömegü testek esetén. A

\footnotetext{
${ }^{17} r=a_{r}\left(1-e_{r} \cos \xi\right), n\left(t-t_{0}\right)=\xi-e_{t} \cos \xi$, és

$\theta-\theta_{0}=2 K \arctan \left(\sqrt{\frac{1+e_{\theta}}{1-e_{\theta}}} \tan \frac{\xi}{2}\right)$ az $1 \mathrm{PN}$ rendü fejlödési egyenletek ( $K$ konstans).
} 
másik irányvonal (Mathisson, Fock és Papapetrou) a multipólmomentumok vizsgálata, amely azt feltételezi, hogy az egyik test által keltett multipól-térben mozog a másik próbarészecskeként figyelembevett test. Ezen leírással könnyebben származtathatóak a mozgásegyenletek, mint a PN formalizmussal. Az ilyen próbarészecskékre vonatkozó mozgást először Infeld és Schild tanulmányozta [64]. Ezen módszerrel az energia-impulzus tenzort a következőképpen lehet megkonstruálni

$$
T^{a b}=\sum_{i} t^{i b}(t) \delta\left(x^{\gamma}-\xi^{\gamma}(t)\right)
$$

ahol $\stackrel{i}{\xi^{\gamma}}$ az $i$-edik test koordinátája $(i=1,2)$ és $\delta\left(x^{\gamma}\right)=\delta\left(x^{1}\right) \delta\left(x^{2}\right) \delta\left(x^{3}\right)$ a háromdimenziós Dirac-delta függvény. Az energia-impulzus tenzor kovariáns deriváltjának az eltűnését megkövetelve $\left(\nabla_{a} T^{a b}=0\right.$, melyet a dinamikai-egyenletnek nevezünk) majd, ezt integrálva a következő írható fel

$$
\int \nabla_{a} T^{a b} \delta d_{(3)} x=0
$$

továbbá

$$
\begin{aligned}
& \int\left(x^{\alpha}-\stackrel{i}{\xi^{\alpha}}\right) \nabla_{a} T^{a b} \delta d_{(3)} x=0,
\end{aligned}
$$

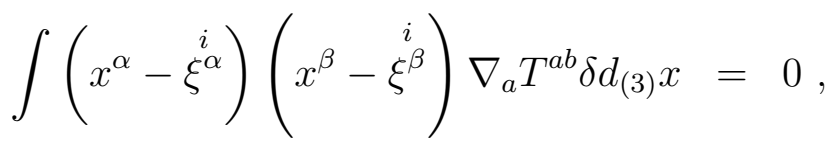

$$
\begin{aligned}
& \int\left(x^{\alpha}-\stackrel{i}{\xi^{\alpha}}\right) \ldots\left(x^{\omega}-\stackrel{i}{\xi}^{\omega}\right) \nabla_{a} T^{a b} \delta d_{(3)} x=0 .
\end{aligned}
$$

A kölcsönhatás típusa (a monopól-dipól, illetve a dipól-dipól) határozza meg, hogy a (4.2.3) egyenletekben milyen magas momentumokat kell használni. Infeld és Plebanski megmutatta, hogy ha dipól-dipól típusú, vagyis két forgó test (spin-spin kölcsönhatás)

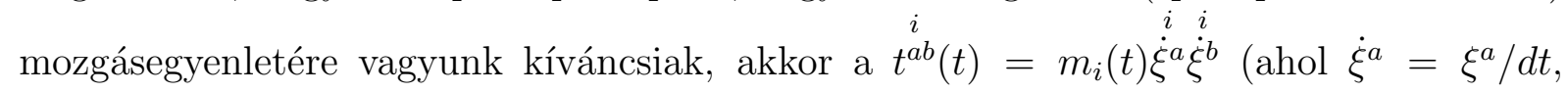
$\left(\dot{\xi}^{0}=1\right)$ és $m_{i}(t)$ az $i$-edik test tömege) választással automatikusan teljesülnek a (4.2:3) egyenletek [16] 피. A mozgásegyenletek kiszámolhatók a (4.23) és a (4.2) metrika sorfejtett használatával. Ezen módszert leginkább a spinek bevezetése miatt használták az 194050-es években [2:3], [24].

\footnotetext{
${ }^{18}$ Látható, hogy $\delta^{3}\left(x^{a}\right)$ háromdimenziós Dirac-delta függvény divergenciák kialakulásához vezet, amelyet a testek tömegének renormalizációjával lehet kiküszöbölni [[15]. További munkákban Infeld és Plebanski bevezettek egy olyan $\hat{\delta}^{3}\left(x^{a}\right)$ Dirac-delta függvényt, amellyel jól kezelhetők a divergenciák [26 $]$.
} 


\subsection{Forgás a mozgásegyenletekben}

Az általános relativitáselméletben a forgás leírásával már az 1930-as évek elején próbálkoztak. Ezen törekvések a geodetikus egyenlet kiterjesztését tűzték ki célul. Amennyiben a téridőben a részecske forog (spinje van), akkor nem-geodektikus mozgásról beszélünk.

A spines részecske mozgásegyenletét Mathisson és Papapetrou írták fel a monopóldipól típusú kölcsönhatásra, amely a klasszikus spin-pálya kölcsönhatásnak felel meg. A mozgásegyenletek származtatásához a dinamikai-egyenletet $\left(\nabla_{a} T^{a b}=0\right)$ használták. Feltették, hogy a részecske kiterjedése sokkal kisebb, mint a gravitációs tér karakterisztikus hossza. Így a részecske mozgása felfogható egy vékony világcsőnek a 4-dimenziós téridőben. Ebben a világcsőben egy világvonal koordinátája $X^{a}\left(X^{0}=t\right)$. A további feltevés az volt, hogy az $X^{\alpha}$,,kis” környezetében, amely kívül esik a világcsővön, az energia-impulzus tenzor tünjön el $\left(T^{a b}=0\right)$.

A spines részecske mozgásegyenleteit először Mathisson [2:3] és Papapetrou [24], majd későbbi formájába Dixon [27] írták fel. Mathisson multipólmomentumokat használt a kovariáns mozgásegyenletek megadásához. A kovariáns Mathisson-egyenletek forgó részecskére a következők

$$
\begin{aligned}
\frac{D}{D \tau}\left(m u^{a}+u_{b} \frac{D S^{a b}}{D \tau}\right) & =-\frac{1}{2} R_{e c d^{a} S^{c d} u^{e},} \\
\frac{D S^{a b}}{D \tau}+u^{a} u_{c} \frac{D S^{b c}}{D \tau}-u^{b} u_{c} \frac{D S^{a c}}{D \tau} & =0,
\end{aligned}
$$

ahol $\tau$ a világvonal sajátideje, $u^{a}=d x^{a} / d \tau$ a négyessebesség, illetve az $S^{a b}$ az antiszimmetrikus spintenzor (6. ábra). A (4.24) és a (4.25) 7 különböző egyenlet, ami 10 változót $\left(S^{a b} ; 6, u^{a} ; 3 m ; 1\right)$ tartalmaz, így az egyenletek nem zártak. Ennek fizikai értelmezése, hogy az egyenletek nem rögzítik a kiterjedt test tömegközéppontját, ezért Mathisson az $S^{a b} u_{a}=0$ mértékválasztást vezette be, amellyel a változók száma 7-re redukálható.

Papapetrou kiterjedt testek energia-impulzusmomentumaiból nem-kovariáns módon definiálta a multipól-momentumokat, vagyis a $\nabla_{a} T^{a b}=0$ dinamikai egyenletből határozta meg a kiterjedt testek világcsövének egyenleteit a dipólmomentumnál magasabb momentumok elhagyásával. Papapetrou eredményei megegyeztek Mathisson (4.24, 4.25) egyenleteivel. Papapetrou és Corinaldesi az egyenletek megoldására az $S^{a 0}=0$ mértékválasztást használta [30] (mivel Schwarzschild téridőt tettek fel, ezért az $S^{a b} k_{a}=0$ választás volt célszerü, ahol a $k_{a}$ négyesvektor időirányú az $m$ Schwarzschild-tömeg nyugalmi rendszerében). Ennek előnye, hogy elkerülhető volt a nem-fizikai spirális mozgás, melyet Weyssenhoff és Raabe mutatott meg 1947-ben [65] a Mathisson-féle segédválasztás 


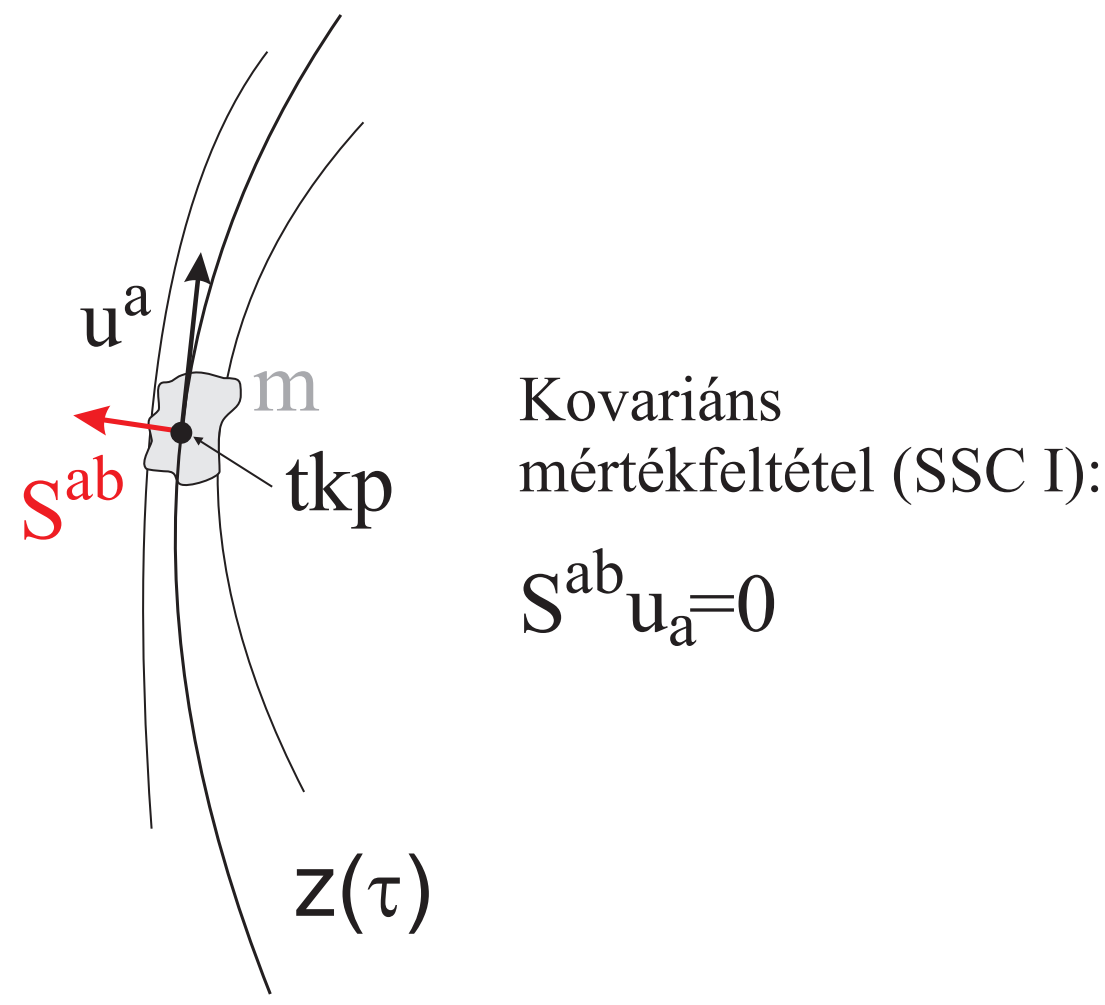

6. ábra. Görbült téridőben mozgó részecske belső struktúrájára (spintenzorára) kirótt egyik lehetséges (Pirani SSC-mérték) választás.

esetén.

Tulczyjew 1959-ben [26] módosította Mathisson elméletet és egyszerüsített formában adta meg a mozgásegyenleteket. A szingularitásokból felépített egy energia-impulzus tenzort és a dinamikai-egyenletből származtatta a mozgásegyenleteket. Azonosította, hogy a (4.24) egyenlet zárójelében lévő mennyisége a $p^{a}$ négyes-impulzusmomentum vektora

$$
p^{a}=m u^{a}+u_{b} \frac{D S^{a b}}{D \tau} .
$$

Ez alapján belátható, hogy sík téridőben $S^{a b} p_{a}=0$, (amely egy újabb mértékválasztása a spines részecske mozgásegyenleteire) melyből $D m / D s=0, D S^{a b} / D s=0$ és $D u^{a} / D s=0$ egyenletek következnek. Látszólag ez a segédválasztás nem kompatibilis az eredeti Mathisson-egyenletekkel (4.24, 4.25), mivel kvadratikus $S^{a b}$-ban, azonban csak dipól tagokat veszünk figyelembe, ezért elhagyható a kvadratikus rész. Tehát Tulczyjew mozgásegyenletei a (4.25) és az alábbiak

$$
m \frac{D u^{a}}{D \tau}=-\frac{1}{2} R_{e c d}^{a} S^{c d} u^{e},
$$

illetve $S^{a b} u_{a}=0$ és $D m / D s=0$.

A továbbiakban a (4.24), (4.2.5) Mathisson-Papapetrou egyenletek rövid levezetésének 
fóbb lépéseit tekintem át, a [66] irodalmat használva.

Az Einstein-egyenlet kiterjeszthető úgy, hogy a ,klasszikus” energia-impulzus tenzorhoz (amelyet a továbbiakban $T_{P}^{a b}$ kanonikus energia-impulzus tenzornak nevezünk) hozzáadunk egy $\nabla_{c} B^{a b c}$,,spinszerü mennyiséget”. Az ily módon kiterjesztett energiaimpulzus tenzor a következő alakú

$$
T^{a b}=T_{P}^{a b}+\nabla_{c} B^{a b c}
$$

ahol $B^{a b c}$ az ún. Belinfante-Rosenfeld-tenzor, valamint $S^{a b}$ az antiszimmetrikus spintenzor

$$
\begin{aligned}
T_{P}^{a b} & =\frac{1}{\sqrt{-g}} \int p^{a} u^{b} \delta^{4}(x-z(\tau)) d \tau, \\
B^{a b c} & =-\frac{1}{2}\left(S^{a b c}+S^{b c a}+S^{c a b}\right), \\
S^{a b c} & =\frac{1}{\sqrt{-g}} \int S^{a b} u^{c} \delta^{4}(x-z(\tau)) d \tau .
\end{aligned}
$$

A továbbiakban megköveteljük, hogy a kiterjesztett energia-impulzus tenzor (4.28) szimmetrikus $\left(T^{(a b)}=0\right)$ legyen, amelyből a fenti definíciókat használva a következőt kapjuk

$$
\frac{1}{\sqrt{-g}} \int\left(p^{a} u^{b}-p^{b} u^{a}\right) \delta^{4}(x-z(\tau)) d \tau-\nabla_{c}\left[\frac{1}{\sqrt{-g}} \int S^{a b} u^{c} \delta^{4}(x-z(\tau)) d \tau\right]=0 \text {. }
$$

A (4.32) egyenletben a következő két egyszerü azonosságot használva

$$
\begin{aligned}
\partial_{a} \sqrt{-g} & =\sqrt{-g} \Gamma_{b a}^{b}, \\
v^{a} \partial_{a} \delta^{4}(x-z(\tau)) & =-\frac{\partial}{\partial \tau} \delta^{4}(x-z(\tau)),
\end{aligned}
$$

és a (4.32) 2. tagjában a kovariáns deriválást elvégezve, majd a felületi tagot elhagyva, a következő adódik

$$
\nabla_{c}\left[\frac{1}{\sqrt{-g}} \int S^{a b} u^{c} \delta^{4}(x-z(\tau)) d \tau\right]=\frac{1}{\sqrt{-g}} \int v^{c} \nabla_{c} S^{a b} \delta^{4}(x-z(\tau)) d \tau .
$$

A $v^{c} \nabla_{c} S^{a b}=D S^{a b} / D \tau$ geodetikus menti deriváltat bevezetve, megkapjuk a egyenlet végső alakját

$$
\frac{1}{\sqrt{-g}} \int\left(p^{a} u^{b}-p^{b} u^{a}\right) \delta^{4}(x-z(\tau)) d \tau=\frac{1}{\sqrt{-g}} \int \frac{D S^{a b}}{D \tau} \delta^{4}(x-z(\tau)) d \tau
$$

amelyből már a (4.24) egyenlet adódik. A továbbiakban a (4.28) a $\nabla_{a} T^{a b}=0$ 
megmaradási egyenletet használjuk, amelyből

$$
\nabla_{a} T_{P}^{a b}+\nabla_{a} \nabla_{c} B^{a b c}=0
$$

A Riemann-tenzor tulajdonsága egy tetszőleges $\phi^{a b}$ másodrendü tenzorra az alábbi

$$
\left(\nabla_{a} \nabla_{b}-\nabla_{b} \nabla_{a}\right) \phi^{c d}=R_{e a b}^{c} \phi^{e d}+R_{e a b}^{d} \phi^{c e}
$$

mivel a Riemann-tenzor szimmetrikus az alsó $\left(R_{b(c d)}^{a}\right)$ két komponensében, így a $B^{a b c}$ tenzorra egyszerüen felírható

$$
\nabla_{a} \nabla_{b} B^{c a b}=\frac{1}{2} R_{a b e}^{c} S^{b e a}
$$

Tehát a (4.37) egyenlet felírható a következő formában

$$
\frac{1}{\sqrt{-g}} \int \frac{D p^{a}}{D \tau} \delta^{4}(x-z(\tau)) d \tau=\frac{1}{\sqrt{-g}} \int \frac{1}{2} R_{a b e}^{c} S^{b e} u^{e} \delta^{4}(x-z(\tau)) d \tau
$$

amely ekvivalens a (4.25) egyenlettel. A Mathisson-Papapetrou-egyenletek tömör alakja a következő

$$
\begin{aligned}
\frac{D S^{a b}}{D \tau} & =p^{a} u^{b}-p^{b} u^{a}, \\
\frac{D p^{a}}{D \tau} & =-\frac{1}{2} R_{e c d}^{a} S^{c d} u^{e}
\end{aligned}
$$

ahol bevezettük a $p^{a}$ négyes-impuzust. Látható, hogy a (4.41), (4.42) egyenletekben szereplő mennyiségek szabadsági foka nagyobb, mint az egyenletek száma Ezért az egyenletek megoldhatósága szempontjából az eredeti (4.24), (425) Mathisson egyenletekhez hasonlóan szükség van valamilyen segédválasztást tenni az $S^{a b}$ spintenzorra. Ezeket nevezzük az SSC (Spin Supplementary Condition) mértékválasztásoknak, melyekből 3-at használnak az irodalomban (történeti okokból négy létezik). Ezek a Pirani (vagy SSC I) [2.5], a Newton-Wigner-Pryce (vagy SSC II) [28], [2.9], a CorinaldesiPapapetrou (SSC III) [30] és a Tulczyew-Dixon (vagy SSC IV) [26], [27] mértékfeltételek, összefoglalva:

$$
\begin{aligned}
S^{a b} u_{a} & =0 & & \text { SSCI }, \\
2 S^{0 b}+u_{a} S^{a b} & =0 & & \text { SSCII } \\
S^{a 0} & =0 & & \text { SSCIII, } \\
S^{a b} p_{a} & =0 & & S S C I V .
\end{aligned}
$$


A legkényelmesebb választás az SSC III, mivel a definíció alapján elegendő a spintenzor komponensei közül az időszerü komponenseket nullának választani. Ekkor a 3-dimenziós spintenzor definíciója $S^{\alpha}=\varepsilon_{\alpha \beta \gamma} S^{\beta \gamma}$, (ahol $\varepsilon_{\alpha \beta \gamma}$ a Levi-Civita szimbólum). A NewtonWigner-Pryce SSC-t a kvantummechanikában a spines részecskéknél használják. Barker és O’Connell megmutatta [68], hogy a gravitáció kvantumos elméletében két 1/2 spinü részecskének a potenciáljából makroszkópikus átmenettel az SSC II-ben felírt gyorsulás kapható. Mivel a spinben elsőrendig használjuk a (4.41, 4.42) egyenleteket, ezért a Pirani és a Tulczyew-Dixon SSC mértékválasztás ugyanahhoz a mozgásegyenlethez vezet (továbbiakban e mértékfeltételre az irodalomban is így számozott SSC III-ra hivatkozok). Az SSC III-t kovariáns SSC-nek is nevezik. Az SSC II mértékválasztás azért fontos, mivel a spin-pálya Lagrange-függvény ebben a mértékben gyorsulásfüggetlen, míg a többi SSCben gyorsulásfüggő. Az SSC-mértékek közti transzformációt nem-geodetikus mozgásra Barker és O'Connell mutatta meg [6ㅁ] $]$.

Belátható, hogy az SSC-függés a spineket tartalmazó kölcsönhatásokat tekintve csak a spin-pálya $\left(S_{i}\right.$-vel arányos tagok) kölcsönhatásában és annak magasabb relativisztikus korrekcióiban lép fel, tehát a spin-spin $\left(S_{1} S_{2}\right.$-vel arányos tagok), és a kvadrupól-monopól ( $S_{i}^{2}$-vel arányos) járulékok SSC-független kölcsönhatások.

\subsection{A spin-pálya kölcsönhatás}

Röviden áttekintem az ún. spin-pálya kölcsönhatás nem-geodetikus egyenletének származtatását a (4.24) és a (4.25) alakú Mathisson-Papapetrou-egyenletek segítségével SSC III illetve SSC I mértékekben.

Legyen $M$ a központi tömeg, melynek gravitációs terében egy $m$ tömegü forgó részecske mozog, amelynek spinje az $S^{a b}$ spintenzorral adható meg (6. ábra). Feltesszük, hogy a metrika alakja a következő

$$
d s^{2}=-g_{00} d t^{2}+g_{\alpha \beta} d x^{\alpha} d x^{\beta}
$$

ahol a derékszögü izotrópikus koordinátákat $g_{00}=1-2 r_{0} / r$ és $g_{\alpha \beta}=\left(1+2 r_{0}\right) \delta_{\alpha \beta}$, amelyben $r_{0}=G M / c^{2}$ (központi tömeg sugara) használjuk. Ezen választás azért célszerú, mert a derékszögü koordinátákban kényelmesen lehet definiálni a háromdimenziós $S^{a}$ spinvektort. Kihasználjuk, hogy az $\mathcal{O}\left(r_{0}^{2}\right) \approx 0$ (mivel csak a vezetőrendű tagokat tartjuk meg), így megkapjuk a Christoffel-szimbólumokat a (4.47) metrikából

$$
\Gamma_{\alpha \beta}^{\gamma}=\frac{r_{0}}{r^{3}}\left(\delta_{\alpha \beta} x^{\gamma}-\delta_{\gamma \beta} x^{\alpha}+\delta_{\alpha \gamma} x^{\beta}\right)
$$

Látható, hogy a Christoffel-szimbólumok nem-eltűnő komponensei a $\Gamma_{\alpha 0}^{0}=\Gamma_{00}^{\alpha}=r_{0} x^{\alpha} / r^{3}$. 
Ezért szükség van még (4.48) a kovariáns deriváltjára is, amelyek az alábbiak

$$
\begin{aligned}
\nabla_{\delta} \Gamma_{\alpha \beta}^{\gamma}= & \frac{r_{0}}{r^{3}}\left(\delta_{\delta \gamma} \delta_{\alpha \beta}-\delta_{\alpha \delta} \delta_{\beta \gamma}-\delta_{\delta \beta} \delta_{\alpha \gamma}\right) \\
& -\frac{r_{0}}{r^{5}}\left(\delta_{\delta \gamma} x^{\alpha} x^{\beta}-\delta_{\beta \gamma} x^{\alpha} x^{\delta}-\delta_{\alpha \gamma} x^{\beta} x^{\alpha}\right) \\
\nabla_{\beta} \Gamma_{\alpha 0}^{0}= & r_{0} / r^{3}\left(\delta_{\alpha \beta}-3 x^{\alpha} x^{\beta} / r^{2}\right)
\end{aligned}
$$

Ezek után a (4.24) egyenletben használjuk a Riemann-tenzor definícióját, valamint az itt kiszámolt Christoffel-szimbólumok kifejezéseit, így megkapjuk a következő egyenletet

$$
\frac{D}{D \tau}\left(m u^{a}\right)+\frac{D}{D \tau}\left(u_{b} \frac{D S^{a b}}{D \tau}\right)+\Gamma_{c e}^{a} u^{e} u_{b} \frac{D S^{c b}}{D \tau}+S^{e f} u^{c}\left(\nabla_{e} \Gamma_{f c}^{a}+\Gamma_{e d}^{a} \Gamma_{f c}^{d}\right)=0
$$

ahol a $D / D \tau\left(u_{b} D S^{a b} / D \tau\right)=d / d \tau\left(u_{b} D S^{a b} D \tau\right)$, mivel a spinben a kvadratikus tagokat elhanyagoljuk. A (4.25) egyenletben a geodetikus menti derivált definíciója alapján

$$
\frac{D S^{a b}}{D \tau}=\frac{d S^{a b}}{d \tau}+\Gamma_{c d}^{a} u^{c} S^{d b}+\Gamma_{c e}^{b} u^{e} S^{a c}
$$

Ezek után használjuk az SSC III mérték definícióját, vagyis $S^{\alpha 0}=0$. Ezen mértékfeltételnek a geodetikus menti deriváltját képezve a (4.5]) egyenlet alapján megkapható

$$
\begin{aligned}
& \frac{D S^{\alpha 0}}{D \tau}=\Gamma_{\delta \gamma}^{0} u^{\gamma} S^{\alpha \delta} \\
& \frac{D S^{0 \beta}}{D \tau}=\Gamma_{\delta \gamma}^{0} u^{\gamma} S^{\delta \beta}
\end{aligned}
$$

és a $D S^{00} / D \tau=0$. Az eredeti Mathisson-Papapetrou (4.25) egyenletekben felhasználjuk a (4.54) egyenletet, így a következő adódik

$$
\frac{D S^{\gamma \beta}}{D \tau}=\Gamma_{\delta \eta}^{0} \frac{u^{\eta}}{u^{0}}\left(u^{\beta} S^{\gamma \delta}-u^{\gamma} S^{\beta \delta}\right)
$$

Ezek után a (4.50) egyenletben használva a (4.54) és a (4.55) egyenleteket, melynek a térszerü részére az alábbi írható

$$
\frac{D}{D \tau}\left(m u^{\alpha}\right)+\frac{d}{d \tau}\left(\Gamma_{\delta \gamma}^{0} \frac{u^{\gamma}}{u^{0}}\left(u_{\beta} u^{\beta} S^{\alpha \delta}-u_{\beta} u^{\alpha} S^{\beta \delta}\right)+\Gamma_{\gamma 0}^{0} u^{0} u_{0} S^{\alpha \gamma}\right)+S^{\gamma \delta} u^{\beta} \nabla_{\gamma} \Gamma_{\delta \beta}^{\alpha}=0
$$

ahol szintén kihasználhatjuk a vezetőrendü $\mathcal{O}\left(r_{0}^{2}\right) \approx 0$ lineáris közelítést, valamint a spinfüggö tagokban az $u^{0} \approx u_{0}, u_{\alpha} \approx-u^{\alpha}, v^{\alpha} \approx u^{\alpha}$ (ahol $v^{\alpha}=d x^{\alpha} / d t$ a háromdimenziós sebesség) közelítéseket és a $u^{a} u_{a}=1$ kifejezést, így megkapjuk a spines részecske nem- 
geodetikus-egyenletét

$$
\frac{D u^{\alpha}}{D \tau}=-\frac{1}{m}\left(v^{\gamma} \nabla_{\gamma} \Gamma_{\delta 0}^{0} S^{\alpha \delta}+v^{\gamma} \nabla_{\delta} \Gamma_{\beta \gamma}^{\alpha} S^{\delta \beta}\right)
$$

Ismét a Christoffel-szimbólumokra kapott kifejezéseket használjuk és bevezetjük a háromdimenziós spinvektort $S^{\alpha}=\varepsilon_{\alpha \beta \gamma} S^{\beta \gamma}$, majd vektoriális jelöléssel a (4.57) egyenlet a következő lesz

$$
\frac{D \mathbf{u}}{D \tau}=\frac{3 r_{0}}{m r^{5}}\left\{[\mathbf{S} \cdot(\mathbf{r} \times \mathbf{v})] \mathbf{r}-r^{2}(\mathbf{v} \times \mathbf{S})+2(\mathbf{v} \cdot \mathbf{r})(\mathbf{r} \times \mathbf{S})\right\}
$$

melyet az $[\mathbf{S} \cdot(\mathbf{r} \times \mathbf{v})] \mathbf{r}=(\mathbf{S} \cdot \mathbf{r})(\mathbf{r} \times \mathbf{v})-(\mathbf{v} \cdot \mathbf{r})(\mathbf{r} \times \mathbf{S})+r^{2}(\mathbf{v} \times \mathbf{S})$ vektorazonosság használatával átírhatunk a következő alakra

$$
\frac{D \mathbf{u}}{D \tau}=\frac{3 r_{0}}{m r^{5}}\{(\mathbf{S} \cdot \mathbf{r})(\mathbf{r} \times \mathbf{v})+(\mathbf{v} \cdot \mathbf{r})(\mathbf{r} \times \mathbf{S})\}
$$

amely egyenlet megegyezik a Schiff által használt Gupta-féle kvantumelméletből kapottal [70] .

A levezetés megismételhető az $S^{a b} u_{a}=0$ SSC II mértékben is. A mértékfeltételnek a geodetikus menti deriváltját képezve és a (4.5]) egyenletből következik a

$$
\frac{D}{D \tau}\left(m u^{a}\right)+S^{\gamma \delta} u^{\beta} \nabla_{\gamma} \Gamma_{\delta \beta}^{a}=0
$$

melyet ismét sorfejtve $\left(\mathcal{O}\left(r_{0}^{2}\right) \approx 0\right.$ és spinben kvadratikus tagokat elhagyva) a térszerü rész a következő

$$
\frac{D}{D \tau}\left(m u^{\alpha}\right)=-S^{\gamma 0} u^{0} \nabla_{\gamma} \Gamma_{00}^{\alpha}-S^{\gamma \beta} u^{\delta} \nabla_{\gamma} \Gamma_{\beta \delta}^{\alpha}
$$

A mértékfeltételt kihasználva $\left(S^{\alpha \beta} u_{\beta}=-S^{\alpha 0} u_{0}\right)$ az előző levezetés alapján a következőt kapjuk

$$
\frac{D u^{\alpha}}{D \tau}=-\frac{1}{m}\left(v_{\delta} \nabla_{\gamma} \Gamma_{00}^{\alpha} S^{\gamma \delta}+v^{\gamma} \nabla_{\delta} \Gamma_{\beta \gamma}^{\alpha} S^{\delta \beta}\right)
$$

mely vektoriális jelöléssel

$$
\frac{D \mathbf{u}}{D \tau}=\frac{3 r_{0}}{m r^{5}}\left\{[2 \mathbf{S} \cdot(\mathbf{r} \times \mathbf{v})] \mathbf{r}-r^{2}(\mathbf{v} \times \mathbf{S})+(\mathbf{v} \cdot \mathbf{r})(\mathbf{r} \times \mathbf{S})\right\} .
$$

Látható, hogy a (4.5.9) és (4.6.3) egyenletek különböző nem-geodetikus mozgást írnak le. A két mérték közti transzformáció meghatározható ha felírjuk a spin nélküli részecske geodetikus mozgásegyenletét

$$
\frac{D \mathbf{u}}{D \tau}=\dot{\mathbf{v}}+\frac{c^{2} r_{0}}{r^{3}} \mathbf{r}+\mathbf{a}_{E}
$$


Az $\mathbf{a}_{E}$ tag $r_{0}$-ban kvadratikus, amely az elsö poszt-newtoni korrekciója a nulladrendü geodetikus mozgásnak (a teljes $1 \mathrm{PN}$ rendnek az $M \gg m$ határesete)

$$
\mathbf{a}_{E}=\frac{r_{0}}{r^{3}}\left(\frac{4 c^{2} r_{0}}{r} \mathbf{r}-v^{2} \mathbf{r}+4(\mathbf{v} \cdot \mathbf{r}) \mathbf{v}\right)
$$

A nem-geodetikus mozgásegyenleteket vizsgálva, melyekben a spines részek

$$
\frac{D \mathbf{u}}{D \tau}=\dot{\mathbf{v}}+\frac{c^{2} r_{0}}{r^{3}} \mathbf{r}+\mathbf{a}_{E}+\mathbf{a}_{S O}^{I, I I, I I I}
$$

ahol bevezetésre kerültek a gyorsulások SSC I és SSC III mértékben (a $\mathbf{a}_{S O}^{I I}$ kompakt kettősökre megtalálható a (5.27) egyenletek határátmenetéből, a teljesség kedvéért ezen gyorsulást is megadtam)

$$
\begin{aligned}
\mathbf{a}_{S O}^{I} & =\frac{3 r_{0}}{m r^{5}}\left\{[2 \mathbf{S} \cdot(\mathbf{r} \times \mathbf{v})] \mathbf{r}-r^{2}(\mathbf{v} \times \mathbf{S})+(\mathbf{v} \cdot \mathbf{r})(\mathbf{r} \times \mathbf{S})\right\}, \\
\mathbf{a}_{S O}^{I I} & =\frac{3 r_{0}}{m r^{5}}\left\{\left[\frac{1}{2} \mathbf{S} \cdot(\mathbf{r} \times \mathbf{v})\right] \mathbf{r}-r^{2}(\mathbf{v} \times \mathbf{S})+\frac{1}{2}(\mathbf{v} \cdot \mathbf{r})(\mathbf{r} \times \mathbf{S})\right\}, \\
\mathbf{a}_{S O}^{I I I} & =\frac{3 r_{0}}{m r^{5}}\left\{[\mathbf{S} \cdot(\mathbf{r} \times \mathbf{v})] \mathbf{r}-r^{2}(\mathbf{v} \times \mathbf{S})+2(\mathbf{v} \cdot \mathbf{r})(\mathbf{r} \times \mathbf{S})\right\} .
\end{aligned}
$$

A $D \mathbf{u} / D \tau=0$ geodetikus egyenletet képezve felírható a forgó részecske gyorsulása a téridőben $\dot{\mathbf{v}}=-G M / c^{2} r^{3}-\mathbf{a}_{E}-\mathbf{a}_{S O}^{I, I I, I I I}$. A transzformáció a két SSC között az elöző gyorsulásokból a következő

$$
\mathbf{r}^{I I I}=\mathbf{r}^{I}+\frac{\mathbf{v} \times \mathbf{S}}{m c^{2}}
$$

$\mathrm{Az} \mathbf{r}^{I I I}$ vektor megadja az $m$ tömegü spines részecske tömegközéppontját az $M$ központi tömeg részecskéhez rögzített nyugalmi rendszerében. Az $\mathbf{r}^{I}$ vektor, pedig a spines részecske tömegközéppontját adja meg a saját koordinátarendszerében.

\subsection{A testek forgása kvantumelméletböl}

A spines részecskére vonatkozó mozgásegyenleteket a gravitáció kvantumelméletének makroszkópikus határátmenetéből is megkapható [77], [72]. Corinaldesi tett elsőként kísérletet arra, hogy az EIH-egyenleteket levezesse két nem forgó részecske egy-graviton kicserélődéséből (Gupta kvantumos elméletéből). A spines részecskék egy-graviton kicserélődését Barker, Gupta és Haracz számolta ki 1966-ban [7:3]. Meghatározták a kicserélődési potenciált két $1 / 2$ spinü részecske között az impulzustéren $1 / c^{2}$ rendig, 
melynek alakja a következő

$$
\begin{aligned}
V= & -\frac{G m_{1} m_{2}}{r^{2}}\left[1+4\left(1+\frac{3 m_{1}}{2 m_{2}}+\frac{3 m_{2}}{2 m_{1}}\right) \frac{P^{2}}{m_{1} m_{2} c^{2}}\right] \\
& +G\left(1+\frac{3 m_{2}}{4 m_{1}}\right) \frac{\hbar \sigma^{(1)}(\mathbf{r} \times \mathbf{P})}{c^{2} r^{3}}+G\left(1+\frac{3 m_{1}}{4 m_{2}}\right) \frac{\hbar \sigma^{(2)}(\mathbf{r} \times \mathbf{P})}{c^{2} r^{3}} \\
& +\frac{G \hbar^{2}}{4 c^{2} r^{3}}\left(\frac{3\left(\sigma^{(1)} \cdot \mathbf{r}\right)\left(\sigma^{(2)} \cdot \mathbf{r}\right)}{r^{2}}-\sigma^{(1)} \cdot \sigma^{(2)}\right) \\
& +\frac{4 \pi G \hbar^{2}}{c^{2}}\left(1+\frac{3 m_{2}}{8 m_{1}}+\frac{3 m_{1}}{8 m_{2}}+\frac{1}{6} \sigma^{(1)} \cdot \sigma^{(2)}\right) \delta(\mathbf{r}),
\end{aligned}
$$

ahol $\mathbf{r}=\mathbf{r}_{1}-\mathbf{r}_{2}, \mathbf{P}$ az $m_{1}$ és $m_{2}$ részecske közös tömegközéppontjának impulzusa, $\sigma^{(i)}$ a Pauli-mátrixok, $\hbar=h /(2 \pi)$, ahol a $h$ Planck-állandó és $\delta(\mathbf{r})$ a Dirac-delta függvény. A $V$ potenciálra magasrendü $\mathcal{O}\left(1 / c^{4}\right)$ számolások [ [r4] irodalomban találhatók. Gupta módszerét felhasználva Barker és O'Connell [75] makroszkópikus átmenettel $\left(\hbar \sigma^{(i)} / 2 \rightarrow \mathbf{S}_{i}\right.$ és $\left.m_{2} \gg m_{1}\right)$ meghatározta a két forgó részecske mozgásegyenletét a SO, a SS és QM-ot tartalmazó kölcsönhatásokra. Tehát a $\hbar \sigma^{(i)} / 2 \rightarrow \mathbf{S}_{i}$ és $m_{2} \gg m_{1}$ limitből a $\mathbf{P} \rightarrow m_{1} \mathbf{v}$ következik, amik használatával a (4.7]) potenciál

$$
\begin{aligned}
V= & -\frac{G m_{1} m_{2}}{r^{2}}\left(1+\frac{3 v^{2}}{2 c^{2}}\right)+\frac{G\left(3 m_{1} \mathbf{S}_{1}+4 m_{2} \mathbf{S}_{2}\right)(\mathbf{r} \times \mathbf{v})}{2 c^{2} r^{3}} \\
& +\frac{G}{c^{2} r^{3}}\left(\frac{3\left(\mathbf{S}_{1} \cdot \mathbf{r}\right)\left(\mathbf{S}_{2} \cdot \mathbf{r}\right)}{r^{2}}-\mathbf{S}_{1} \cdot \mathbf{S}_{2}\right)
\end{aligned}
$$

A Lagrange-függvény a szabad részecskére felírt $\mathcal{L}=\mathcal{L}_{\text {szabad }}-V$ egyenletből kapható meg.

Magasabb rendü spinekben jelenleg effektív térelméleteket is alkalmaznak a PN számolásokra [76], [77], [78].

\subsection{Spinprecessziós egyenletek}

A spinprecessziós egyenletek a spinek szögmozgásán kívül kapható egyenletek, melyek más időskálán precesszálnak, mint a mozgás pálya periódusa. Először Barker és O’Connell származtatta a kvantumtérelmélet makroszkópikus átmenetéből [ [75], emellett kovariánsan is levezették [[79], [80], [81]]. A SO és SS kölcsönhatás relativisztikus korrekciója ismert, így a spinprecessziós egyenletek 1 PN-es korrekcióját is megadták [82]. A spinprecesszióra vonatkozó SO, SS és QM járulékok a következők (․ ábra)

$$
\begin{aligned}
& \dot{\mathbf{S}}_{\mathbf{1}}=\frac{G}{c^{2} r^{3}}\left[\frac{4+3 \nu}{2} \mathbf{L}_{\mathbf{N}}-\mathbf{S}_{\mathbf{2}}+\frac{3 \mathbf{r}}{r^{2}}\left[\left(\mathbf{r} \cdot \mathbf{S}_{\mathbf{2}}\right)-\gamma_{1}\left(\mathbf{r} \cdot \mathbf{S}_{\mathbf{1}}\right)\right]\right] \times \mathbf{S}_{\mathbf{1}} \\
& \dot{\mathbf{S}}_{\mathbf{2}}=\frac{G}{c^{2} r^{3}}\left[\frac{4+3 \nu^{-1}}{2} \mathbf{L}_{\mathbf{N}}-\mathbf{S}_{\mathbf{1}}+\frac{3 \mathbf{r}}{r^{2}}\left[\left(\mathbf{r} \cdot \mathbf{S}_{\mathbf{1}}\right)-\gamma_{2}\left(\mathbf{r} \cdot \mathbf{S}_{\mathbf{2}}\right)\right]\right] \times \mathbf{S}_{\mathbf{2}},
\end{aligned}
$$


ahol $\nu=m_{2} / m_{1}$ és $\gamma_{i}=\mu m^{3} c^{2} p_{i} / S_{i}^{2}$. A spinben lineáris tag a $\mathrm{SO}$, a $\gamma_{i}$ mennyiséggel arányos a QM és az spinben négyzetes mennyiséggel arányos tagok a SS járulékok. A $\gamma_{i}$-ben szereplő $p_{i}=Q_{i} / m_{i} m^{2}$ bevezetett mennyiségben a $Q_{i}$ az egyes testekhez tartozó kvadrupól-momentum skalár (fekete lyukakra a $Q_{i}=-\tilde{\chi}_{i}^{2} m_{i}^{3}$, melynél a $\tilde{\chi}_{i}=c S_{i} / m_{i}^{2} G$ a dimenziómentes spin, neutroncsillagokra a $Q_{i} \simeq-a \tilde{\chi}_{i}^{2} / m_{i}^{3}$ ए9, ahol a a neutroncsillag állapotegyenletétől függő állandó, értéke 4 és 8 között mozog [21], [83]).

A spinek leírásának egyszerüsítése miatt, érdemes bevezetni a $\kappa_{i}=\cos ^{-1}\left(\hat{\mathbf{L}}_{\mathbf{N}}\right.$ $\left.\cdot \hat{\mathbf{S}}_{\mathbf{i}}\right)$ és $\gamma=\cos ^{-1}\left(\hat{\mathbf{S}}_{\mathbf{1}} \cdot \hat{\mathbf{S}}_{\mathbf{2}}\right)$ relatív polárszögeket, melyekkel a spinvektorok az $\mathbf{S}_{\mathbf{i}}=S_{i}\left(\sin \kappa_{i} \cos \psi_{i}, \sin \kappa_{i} \sin \psi_{i}, \cos \kappa_{i}\right)$ alakba írhatók (ahol $\psi_{i}$ az $\mathbf{S}_{\mathbf{i}}$ spinvektoroknak a pályasíkra vetített azimutális relatív szögei $\square$. ábra).

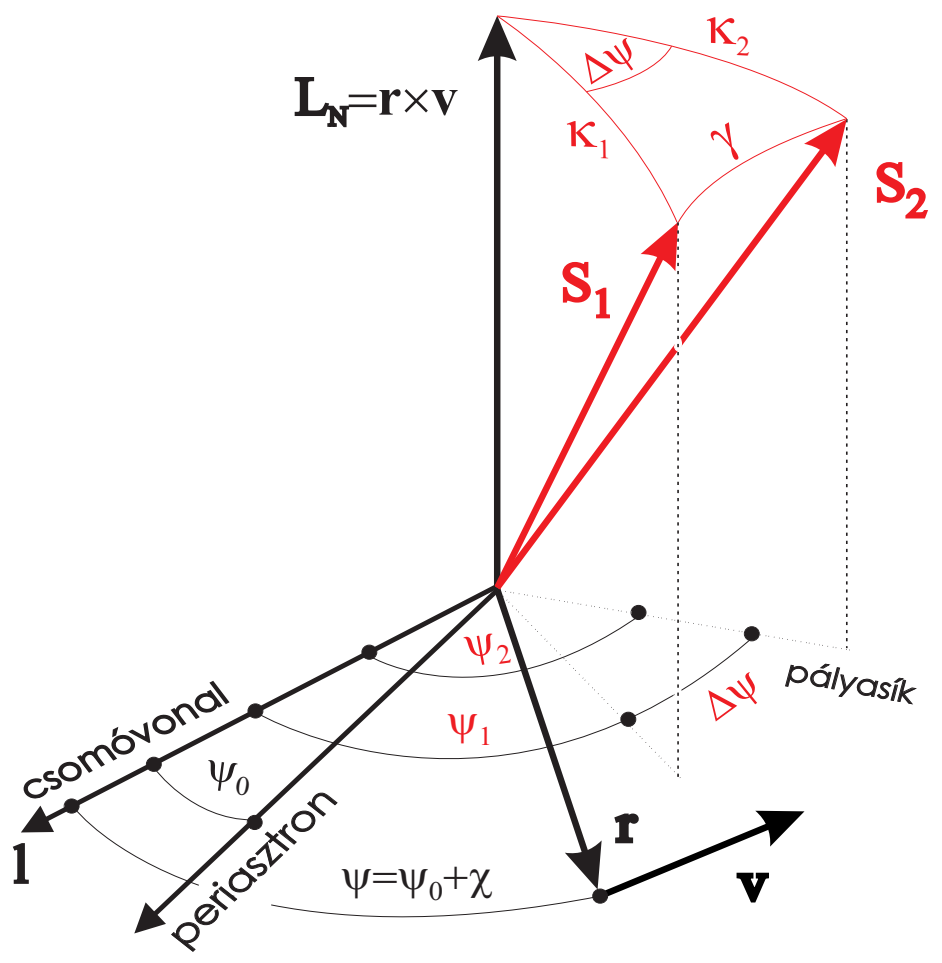

7. ábra. A spinvektorok geometriája a kettős pályasíkjához képest. A koordinárarendszert a pályasíkra merőleges $\boldsymbol{L}_{N}$ pálya-impulzusmomentum vektorhoz rögzítjük. Így az $\mathbf{S}=\mathbf{S}_{1}+\mathbf{S}_{2}$ spinvektor, a pályasíkot az $\boldsymbol{L}_{N}$ pálya-impulzusmomentum vektor határozza meg, melyre merőleges az $\mathbf{l}$ csomóvonal, amely segítségével felírhatók az azimutális $\psi_{i}$ és $\psi_{0}$ szögek. Bevezetésre kerültek még a következő relatív polárszögek $\kappa_{i}=\cos ^{-1}\left(\hat{\boldsymbol{L}}_{N} \cdot \hat{\mathbf{S}}_{\mathbf{i}}\right), \gamma=\cos ^{-1}\left(\hat{\mathbf{S}}_{\mathbf{1}} \cdot \hat{\mathbf{S}}_{\mathbf{2}}\right)$ és $\Delta \psi=\psi_{2}-\psi_{1}$.

Amennyiben a DD kölcsönhatást is figyelembe vesszük, akkor a (4.73) spinprecesziós

\footnotetext{
${ }^{19} \mathrm{~A}$ newtoni elméletben a kvadrupólmomentum-skalár definíciója adott $\rho(x)$ tömegsürüségre $Q_{i}=$ $\int_{i} \rho(x)|x|^{2} P_{2}(\hat{s} \cdot \hat{x}) d^{3} x$, ahol $P_{2}(x)=\left(3 x^{2}-1\right) / 2$ egy Legendre-polinom.
} 
egyenletekhez még a következő egyenletek csatolódnak

$$
\begin{aligned}
& \dot{\mathbf{S}}_{\mathbf{1}}=-\frac{1}{r^{3}}\left[3\left(\hat{\mathbf{r}} \cdot \mathbf{d}_{\mathbf{2}}\right) \hat{\mathbf{r}}-\mathbf{d}_{\mathbf{2}}\right] \times \mathbf{d}_{\mathbf{1}}, \\
& \dot{\mathbf{S}}_{\mathbf{2}}=-\frac{1}{r^{3}}\left[3\left(\hat{\mathbf{r}} \cdot \mathbf{d}_{\mathbf{1}}\right) \hat{\mathbf{r}}-\mathbf{d}_{\mathbf{1}}\right] \times \mathbf{d}_{\mathbf{2}},
\end{aligned}
$$

ahol $\mathbf{d}_{\mathbf{i}}$ az $i$-edik test mágneses dipólmomentuma. Érdemes bevezetni a $\mathbf{d}_{\mathbf{i}}$ mágneses dipólokhoz a $\left(\hat{\mathbf{l}}_{\mathbf{i}}, \hat{\mathbf{S}}_{\mathbf{i}} \times \hat{\mathbf{l}}_{\mathbf{i}}, \hat{\mathbf{S}}_{\mathbf{i}}\right)$ koordinátarendszereket, ahol $\hat{\mathbf{l}}_{\mathbf{i}}$ az egyes $\hat{\mathbf{S}}_{\mathbf{i}} \times \hat{\mathbf{l}}_{\mathbf{i}}$ irányú egységvektor (《) ábra). A $\lambda=\cos ^{-1}\left(\hat{\mathbf{d}}_{\mathbf{1}} \cdot \hat{\mathbf{d}}_{\mathbf{2}}\right)$, valamint $\alpha_{i}$ és $\beta_{i}$ polárszögekkel az $i$-edik mágneses dipólmomentum egységvektor felírható a $\hat{\mathbf{d}}_{\mathbf{i}}=\left(\sin \alpha_{i} \cos \beta_{i}, \sin \alpha_{i} \sin \beta_{i}, \cos \alpha_{i}\right)$ alakban (《. ábra), mellyel megadhatók a dipólmomentumok mozgása.

Mivel az egyenletek nem zártak, így szükség van a $\dot{\mathbf{d}}_{\mathbf{i}}$ egyenletekre, melyeket a pulzárok magnetohidrodinamikai elméletéből kaphatunk meg, amelyben $\dot{\mathbf{d}}_{\mathbf{i}}=\mathbf{S}_{i} / Q_{i} \times \mathbf{d}_{\mathbf{i}}$ (《). ábra).

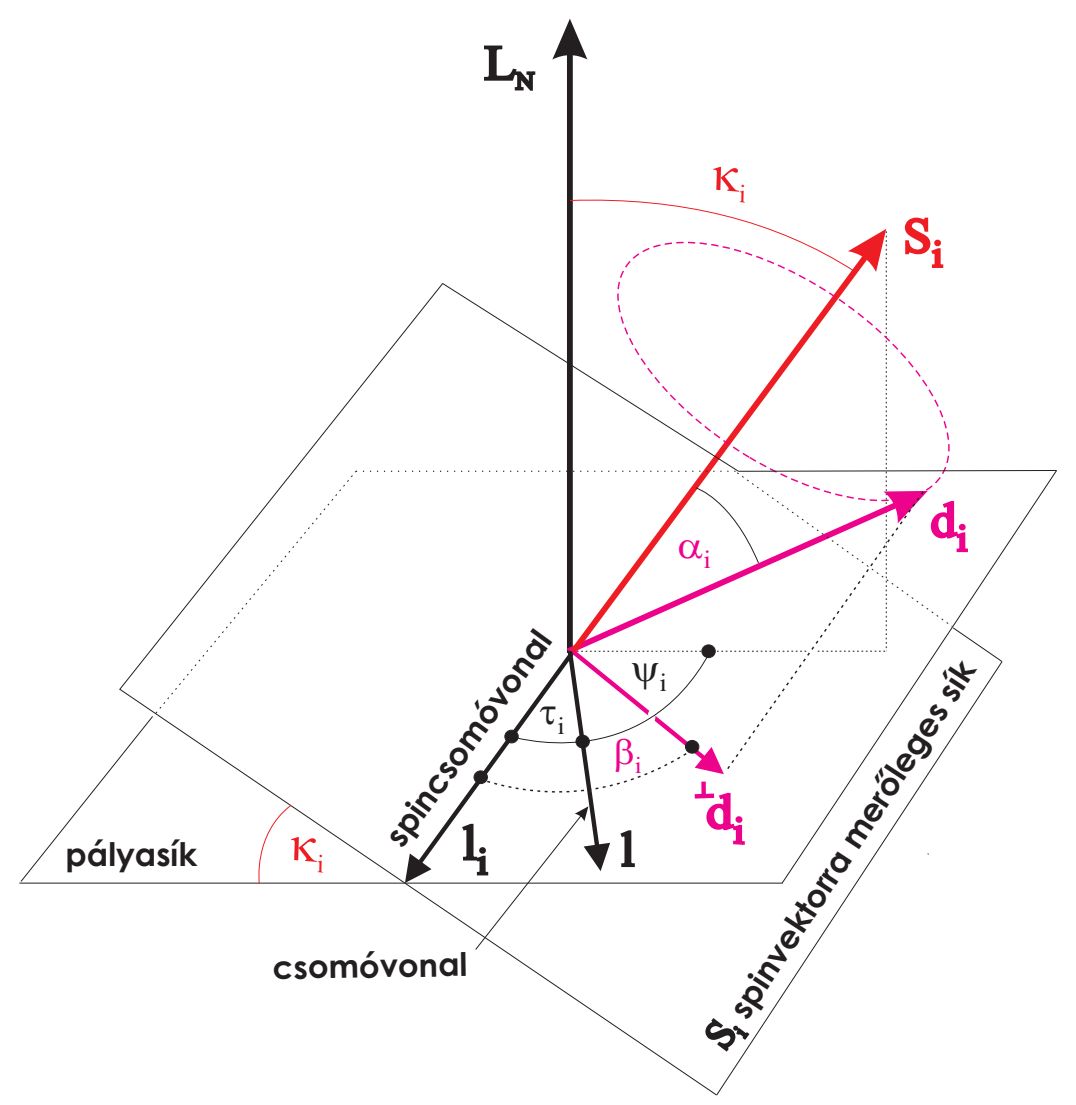

8. ábra. $\mathrm{Az}$ egyes $\mathbf{S}_{\mathbf{i}}$ spinvektorok körül precesszáló $\mathbf{d}_{\mathbf{i}}$ mágneses dipólmomentum vektorok. A spinvektorokhoz tartoznak $\mathbf{l}_{i}$ csomóvonalak, mely segítségével bevezethetők a $\tau_{i}$ és $\beta_{i}$ szögek. Továbbá az $\alpha_{i}$ jelöli az $\mathbf{S}_{\mathbf{i}}$ és $\mathbf{d}_{\mathbf{i}}$ vektorok közti polárszögeket (a $\mathbf{d}_{\mathbf{1}}$ és $\mathbf{d}_{\mathbf{2}}$ közti szög a $\lambda$ ).

A spinprecesssziós egyenletek precessziós szögsebességéből adódó periódusidő sokkal kisebb, mint a kepleri pálya periódusideje, ezért Barker és O’Connell egy pálya periódusra 
átlagolta a (4.73) egyenleteket [75], melyek az SO SS és QM esetén az alábbiak ${ }^{201}$

$$
\begin{aligned}
& \dot{\mathbf{S}}_{\mathbf{1}}=\frac{G}{2 c^{2} \bar{r}^{3}}\left((4+3 \eta) \mathbf{L}_{\mathbf{N}}+\mathbf{S}_{\mathbf{2}}-3\left[\left(\hat{\mathbf{L}}_{\mathbf{N}} \cdot \mathbf{S}_{\mathbf{2}}\right)-\gamma_{1}\left(\hat{\mathbf{L}}_{\mathbf{N}} \cdot \mathbf{S}_{\mathbf{1}}\right)\right] \hat{\mathbf{L}}_{\mathbf{N}}\right) \times \mathbf{S}_{\mathbf{1}} \\
& \dot{\mathbf{S}}_{\mathbf{2}}=\frac{G}{2 c^{2} \bar{r}^{3}}\left(\left(4+3 \eta^{-1}\right) \mathbf{L}_{\mathbf{N}}+\mathbf{S}_{\mathbf{1}}-3\left[\left(\hat{\mathbf{L}}_{\mathbf{N}} \cdot \mathbf{S}_{\mathbf{1}}\right)-\gamma_{2}\left(\hat{\mathbf{L}}_{\mathbf{N}} \cdot \mathbf{S}_{\mathbf{2}}\right)\right] \hat{\mathbf{L}}_{\mathbf{N}}\right) \times \mathbf{S}_{\mathbf{2}}
\end{aligned}
$$

és DD kölcsönhatás esetén a következő

$$
\begin{aligned}
& \dot{\mathbf{S}}_{\mathbf{1}}=-\frac{1}{\bar{r}^{3}}\left[\mathbf{d}_{\mathbf{2}}-3\left(\mathbf{d}_{\mathbf{2}} \cdot \hat{\mathbf{L}}_{\mathbf{N}}\right) \hat{\mathbf{L}}_{\mathbf{N}}\right] \times \mathbf{d}_{\mathbf{1}} \\
& \dot{\mathbf{S}}_{\mathbf{1}}=-\frac{1}{\bar{r}^{3}}\left[\mathbf{d}_{\mathbf{1}}-3\left(\mathbf{d}_{\mathbf{1}} \cdot \hat{\mathbf{L}}_{\mathbf{N}}\right) \hat{\mathbf{L}}_{\mathbf{N}}\right] \times \mathbf{d}_{\mathbf{2}}
\end{aligned}
$$

ahol $\bar{r}$ egy ,átlagolt” sugár²⿴囗. Az átlagolt spinprecessziós egyenletek SO és SS járulékát a vezetőrendű sugárzás jelenlétében Apostolatos, Cutler, Thorne és Sussman [4.9] vizsgálta először. Kimutatták azt a jelenségét, melynél (a kettős rendszer fejlődésének kezdetén az $L>S$ eset áll fenn) a gravitációs sugárzás miatt az $L$ pálya-impulzusmomentum nagysága folyamatosan csökken ( $S$ nagyságának változása magasabb rendben jelentkezik, így itt állandónak tekinthető). Amikor az $L$ összemérhető lesz az $S$ nagyságával, akkor az $\mathbf{L}$ vektor átfordul egy másik állapotba. Ez az úgynevezett spin-flip jelenség. melynek tömegaránytól való függését a [84] irodalomban vizsgálták.

A (4.75) átlagolt spinprecessziós egyenletek megoldását Racine adta meg a SO, SS és QM esetekben $[\underline{8.5}]^{[2]}$. A (4.7.3) pillanatnyi egyenletek megoldása PN sorfejtéssel a [866] irodalomban található.

\footnotetext{
${ }^{20} \mathrm{~A}$ Barker és O’Connell általt bevezetett pálya periódusra vett átlagolás lényegében egy kepleri koordinátarendszerben való szögátlagolást jelent (a pericentrum az $x$ irányba, az impulzusmomentumvektor a $z$ irányba mutat, a pálya síkja az $x$ és $y$ síkban van), amely a következő $\langle g(x, y, \dot{x}, \dot{y})\rangle=$ $\frac{1}{T} \int_{0}^{T} g(x, y, \dot{x}, \dot{y}) d t=\frac{1}{T} \int_{0}^{2 \pi} g(x, y, \dot{x}, \dot{y}) \frac{d t}{d \chi} d \chi$

ahol $g(x, y, \dot{x}, \dot{y})$ egy tetszőleges függvénye a koordinátáknak és azok időderiváltjainak.

${ }^{21}$ Látható, hogy a spinprecessziós egyenletek SO része ugyanolyan alakúak, mint az átlagolt esetben.

${ }^{22} \mathrm{~A}$ megoldások retardált Green függvények segítségével adhatók meg egyenlő tömegü esetben, tetszőleges tömegekre pedig perturbatív megoldással.
} 


\section{Kettösök radiális mozgása}

Ebben a fejezetben a kompakt kettősök radiális dinamikájának megoldását ismertetem [35]. A kepleri vagy klasszikus kéttest-probléma (melyet a poszt-newtoni rendek szerint nulladrendnek mondunk) ekvivalens az egycentrum-problémával, amely egy $m$ tömegü test terében lévő $\mu$ tömegú részecske mozgását adja meg. A továbbiakban a dolgozatban minden mozgásegyenletet az egycentrum-probléma esetben használom.

A nulladrendhez adódó lineáris perturbációkat, nevezetesen az 1 PN tisztán relativisztikus korrekciót, a SO, SS, QM és DD kölcsönhatásokat vizsgálom. Az irodalomban jelenleg 3.5 PN rendig ismertek a tisztán relativisztikus korrekciókból származó mozgásegyenletek. A SO kölcsönhatás 1.5 PN, míg a SS, QM és DD formálisan 2 PN rendű járulékok (mivel a SO, SS, QM és DD vezetőrendűek, ezért tekinthetők lineáris perturbációként a nulladrendhez képest). Az irodalomban ismert a SO [87], [88], [8.9] és SS [90] kölcsönhatások következő rendü korrekciójának a mozgásegyenlete is, ami a poszt-newtoni rendeket illetően 2.5 PN, 3 PN rendnél jelentkeznek. Manapság a spint tartalmazó magasrendű (akár 3 PN) Hamilton-függvényeket a kovariáns tárgyaláson kívül effektív térelméletekből is származtatják [[77], [[r8].

Az 1 PN korrekciót tartalmazó mozgás megoldását Damour és Deruelle származtatta először 1985-ben [17], amelyben Lagrange-formalizmuson keresztül a mozgásállandók bevezetésével felírták a radiális és szögegyenletet. Ezen egyenleteket egy alkalmas parametrizációval megoldották lineáris rendig, melyben 3-féle excentricitás szerepelt. Schäfer és Wex 1993-ban a Hamilton formalizmus segítségével megadta a ,tisztán” relativisztikus 2 PN rendü mozgás leírását, vagyis a Kepler-egyenletet [18],

$$
n^{2 P N}\left(t-t_{0}\right)=u-e_{t}^{2 P N} \sin u+f_{p}^{2 P N} \sin v+g_{p}^{2 P N}(v-u)
$$

ahol $u$ az excentrikus anomália, $v$ a Damour és Deruelle által bevezetett általánosítása a kepleri valódi anomáliának. Az $n^{2 P N}$ a középmozgás, amely a $T$ pálya periódusidővel adható meg

$$
\begin{aligned}
T= & \frac{2 \pi G m}{(-2 E / \mu)^{3 / 2}}\left[1-(\eta-15) \frac{E}{4 c^{2} \mu}\right. \\
& \left.-\frac{3}{32}\left(35+30 \eta+3 \eta^{2}\right) \frac{E^{2}}{c^{4} \mu^{2}}+\frac{3}{2}(5-2 \eta) \frac{\mu(-2 E / \mu)^{3 / 2}}{c^{4} L}\right]
\end{aligned}
$$

$\left(n^{2 P N}=2 \pi / T\right)$ és $e_{t}^{2 P N}$ az idö-excentricitás, ezek a pályaelemek 1 PN és 2 PN korrekciókat tartalmaznak. A (5.]) Kepler-egyenletben szereplö további mennyiségek az $f_{p}^{2 P N}, g_{p}^{2 P N}$ csak 2 PN rendü járulékot tartalmaznak. A magasabb rendü relativisztikus korrekciókat (3 PN) tartalmazó kvázi-elliptikus mozgást Memmesheimer, Gopakumar és Schäfer írta 
fel 2004-ben [1].

A spinek figyelembevételével (SO, SS kölcsönhatás) a mozgás leírása meglehetősen bonyolult, mivel a spinek sok szabadsági fokkal növelik a mozgás paramétereinek számát, vagyis sok relatív szögváltozó bevezetése szükséges a klasszikus nulladrendü dinamikához képest. A korábban bemutatott egyes járulékokból levezethető spinprecessziós egyenletek tovább bonyolítják a mozgás szögrészét. A tisztán relativisztikus 1 PN korrekcióra igaz hogy, a pályasík megmarad a mozgás folyamán, míg SS, QM és DD esetben a pályasík nem megmaradó.

A SO kölcsönhatás Hamilton-formalizmusát Wex adta meg először 1995-ben [9]], amelyben a spinprecessziós egyenletekből származó korrekciókat nem vette figyelembe. Az irodalomban a spines rendszerekre általában olyan egyszerüsítéseket tesznek, ahol csak az egyik testnek van spinje, illetve az ezzel matematikailag analóg egyenlő tömegü esetet használják [4.9].

A mozgásegyenletek származtatásánál a Lagrange-formalizmusból indulunk ki. Ismert, hogy a vizsgált lineáris perturbációk (hasonlóan, mint a Damour-Deruelle leírásban) radiális és szög-részére vonatkozó egyenletei szétcsatolódnak.

A SO kölcsönhatás egyszerüsítéséhez az SSC II-es mértékben felírt Lagrange-függvényt használom, mivel az nem tartalmaz gyorsulást és emiatt egyszerűbb alakú lesz a radiális egyenlet.

A mozgás tárgyalása folyamán a radiális egyenletek vizsgálatára szorítkozom. Az általánosított valódi anomália $r(\chi)$ parametrizáció segítségével átírható az egyenletek $r$ függése a valódi anomália függésre, majd időben kiintegrálhatóak lesznek az egyenletek a lineáris perturbációk figyelembevételével. Ezek után egyszerüsítésképpen átírható a $\chi$ valódi anomália függése a $\xi$ excentrikus anomália függésre, amellyel megkapható az égi mechanikában ismert Kepler-egyenlet általánosítása, amely tartalmazza a vizsgált járulékok lineáris perturbációit. Megmutatom, hogy a fordulópontokból általánosított parametrizáció ugyanazt Kepler-egyenletet adja, mint a Damour-Deruelle leírásban [I7].

\subsection{Lineáris járulékok a kepleri pályákhoz}

A kompakt kettősök lineáris perturbációkat tartalmazó Lagrange-függvénye a következő (1 PN [17], SO, SS [20], QM [21] és DD [22] )

$$
\mathcal{L}=\frac{\mu \mathbf{v}^{2}}{2}+\frac{G m \mu}{r}+\mathcal{L}_{P N}+\mathcal{L}_{S O}^{I I}+\mathcal{L}_{S S}+\mathcal{L}_{Q M}+\mathcal{L}_{D D}
$$


ahol a kepleri tagokon kívül az egyes járulékok a következők $\left(\mathcal{L}_{S O}^{I I}\right.$-vel jelölöm az SSC II mértékben felírt Lagrange függvényt, és az ,1 PN" korrekciót csak ,,PN"-nek rövidítem)

$$
\begin{aligned}
\mathcal{L}_{P N} & =\frac{1}{8 c^{2}}(1-3 \eta) \mu v^{4}+\frac{G m \mu}{2 r c^{2}}\left[(3+\eta) v^{2}+\eta \dot{r}^{2}-\frac{G m}{r}\right], \\
\mathcal{L}_{S O}^{I I} & =\frac{G \mu}{2 c^{2} r^{3}} \mathbf{v} \cdot[\mathbf{r} \times(4 \mathbf{S}+3 \boldsymbol{\sigma})], \\
\mathcal{L}_{S S} & =\frac{G}{c^{2} r^{3}}\left[\left(\mathbf{S}_{\mathbf{1}} \cdot \mathbf{S}_{\mathbf{2}}\right)-\frac{3}{r^{2}}\left(\mathbf{r} \cdot \mathbf{S}_{\mathbf{1}}\right)\left(\mathbf{r} \cdot \mathbf{S}_{\mathbf{2}}\right)\right], \\
\mathcal{L}_{Q M} & =\frac{G \mu m^{3}}{2 r^{5}} \sum_{i=1}^{2} p_{i}\left[3\left(\hat{\mathbf{S}}_{\mathbf{i}} \cdot \mathbf{r}\right)^{2}-r^{2}\right], \\
\mathcal{L}_{D D} & =\frac{1}{r^{3}}\left[3\left(\mathbf{n} \cdot \mathbf{d}_{\mathbf{1}}\right)\left(\mathbf{n} \cdot \mathbf{d}_{\mathbf{2}}\right)-\mathbf{d}_{\mathbf{1}} \cdot \mathbf{d}_{\mathbf{2}}\right]
\end{aligned}
$$

ahol $m=m_{1}+m_{2}$ az össztömeg, $\mu=m_{1} m_{2} / m$ a redukált tömeg, $\eta=\mu / m$ a szimmetrikus tömegarány, $\mathbf{S}_{\mathbf{i}}$ az $i$-edik test spinvektora $\left(S_{i}\right.$ a spinvektor nagysága és $\hat{\mathbf{S}}_{\mathbf{i}}$ az egységvektora), $\mathbf{S}=\mathbf{S}_{\mathbf{1}}+\mathbf{S}_{\mathbf{2}}$ a teljes spinvektor, $\boldsymbol{\sigma}=\left(m_{2} / m_{1}\right) \mathbf{S}_{\mathbf{1}}+\left(m_{1} / m_{2}\right) \mathbf{S}_{\mathbf{2}}$ a tömegaránnyal súlyozott spin, $\mathbf{d}_{\mathbf{i}}$ a mágneses dipólmomentum-vektor és $p_{i}$ egy bevezetett mennyiség, melyet a "Spinprecessziós egyenletek" címü alfejezetben tárgyaltam, forgó fekete lyukakra $p_{i}=-\left(c S_{i} / G m_{i} m\right)^{2}$. Célszerü a vektorok skalárszorzatait kifejteni a $\square$. és 8 . ábrákon bevezetett relatív szögek segítségével, melyet a későbbiekben használni fogok.

A Lagrange-függvényből (5.4) származtatható a mozgásegyenlet, vagyis a gyorsulás

$$
\mathbf{a}=-\frac{G m}{r^{2}} \mathbf{n}+\mathbf{a}_{P N}+\mathbf{a}_{S O}^{I I}+\mathbf{a}_{S S}+\mathbf{a}_{Q M}+\mathbf{a}_{D D}
$$

ahol az első nulladrendű (nevezik ,,newtoni” vagy ,,kepleri” gyorsulásnak is) tagon kívül az egyes tagok a következők

$$
\begin{aligned}
\mathbf{a}_{P N} & =\frac{G m}{c^{2} r^{2}}\left\{\mathbf{n}\left[(4+2 \eta) \frac{G m}{r}-(1+3 \eta) v^{2}+\frac{3}{2} \eta \dot{r}^{2}\right]+(4-2 \eta) \dot{r} \mathbf{v}\right\}, \\
\mathbf{a}_{S O}^{I I} & =\frac{G}{c^{2} r^{3}}\left\{\frac{3}{2 r^{2}} \mathbf{r}[(\mathbf{r} \times \mathbf{v}) \cdot(4 \mathbf{S}+3 \boldsymbol{\sigma})]-\mathbf{v} \times(4 \mathbf{S}+3 \boldsymbol{\sigma})+\frac{3 \dot{r}}{2 r} \mathbf{r} \times(4 \mathbf{S}+3 \boldsymbol{\sigma})\right\}, \\
\mathbf{a}_{S S} & =-\frac{3 G}{c^{2} \mu r^{7}}\left\{r^{2}\left[\mathbf{r}\left(\mathbf{S}_{\mathbf{1}} \cdot \mathbf{S}_{\mathbf{2}}\right)+\mathbf{S}_{\mathbf{1}}\left(\mathbf{r} \cdot \mathbf{S}_{\mathbf{2}}\right)+\mathbf{S}_{\mathbf{2}}\left(\mathbf{r} \cdot \mathbf{S}_{\mathbf{1}}\right)\right]-5 \mathbf{r}\left(\mathbf{r} \cdot \mathbf{S}_{\mathbf{1}}\right)\left(\mathbf{r} \cdot \mathbf{S}_{\mathbf{2}}\right)\right\}, \\
\mathbf{a}_{Q M} & =-\frac{3 G m^{3}}{2 r^{7}} \sum_{i=1}^{2} p_{i}\left[5\left(\hat{\mathbf{S}}_{\mathbf{i}} \cdot \mathbf{r}\right)^{2}-r^{2}\right] \mathbf{r}+\frac{3 G m^{3}}{r^{5}} \sum_{i=1}^{2} p_{i}\left(\hat{\mathbf{S}}_{\mathbf{i}} \cdot \mathbf{r}\right) \hat{\mathbf{S}}_{\mathbf{i}}, \\
\mathbf{a}_{D D} & =\frac{3}{\mu r^{4}}\left\{\left[\mathbf{d}_{\mathbf{1}} \cdot \mathbf{d}_{\mathbf{2}}-5\left(\mathbf{n} \cdot \mathbf{d}_{\mathbf{1}}\right)\left(\mathbf{n} \cdot \mathbf{d}_{\mathbf{2}}\right)\right] \mathbf{n}+\sum_{i \neq j}\left(\mathbf{n} \cdot \mathbf{d}_{\mathbf{i}}\right) \mathbf{d}_{\mathbf{j}}\right\} .
\end{aligned}
$$

A radiális egyenleteket a gyorsulások integrálása helyett a Lagrange-függvényből (5.4) 
kapható első integrálok segítségével állítható elő, majd a mozgásállandók és a dinamikai változók $(\mathbf{v}, \mathbf{r})$ közti összefüggésekből kifejezhető az $\dot{r}^{2}$, vagyis a radiális egyenlet [92]. Az összes lineáris perturbációt tartalmazó radiális egyenlet a következő lesz

$$
\dot{r}^{2}=\frac{2 E}{\mu}+\frac{2 G m}{r}-\frac{\bar{L}^{2}}{\mu^{2} r^{2}}+\sum_{i=0}^{3} \frac{\delta A_{i}}{r^{i}}-\frac{2 \bar{L} \delta L}{\mu^{2} r^{2}}-\frac{2 \delta E}{\mu} .
$$

ahol $\delta A_{i}$ az 1 PN korrekciókban fellépő állandók, melyek az energia és az impulzusmomentum nagyságával megadhatóak (四. táblázat).

1. táblázat. Az 1 PN járulékból kapható konstansok $\delta A_{i}$.

$$
\begin{array}{ll}
\hline \hline \delta A_{0} & 3(3 \eta-1) \frac{E^{2}}{c^{2} \mu^{2}} \\
\delta A_{1} & 2(7 \eta-6) \frac{E G m}{c^{2} \mu} \\
\delta A_{2} & -2(3 \eta-1) \frac{E \bar{L}^{2}}{c^{2} \mu^{3}}+(5 \eta-10) \frac{G^{2} m^{2}}{c^{2}} \\
\delta A_{3} & (-3 \eta+8) \frac{G^{2} m^{2} \bar{L}^{2}}{c^{2} \mu^{2}} \\
\hline \hline
\end{array}
$$

2. táblázat. A $\delta L$ változó értékei.

\begin{tabular}{ll}
\hline \hline$S O$ & $\frac{G \mu}{2 c^{2} r} \sum_{i=1, j \neq i}^{2} \frac{4 m_{i}+3 m_{j}}{m_{i}} S_{i} \cos \kappa_{i}$ \\
$S S$ & $-\frac{G \mu^{2}}{2 c^{2} \bar{L}^{3}} S_{1} S_{2} \sin \kappa_{1} \sin \kappa_{2}\left\{2 \bar{A} \cos \left[\chi+2\left(\psi_{0}-\bar{\psi}\right)\right]\right.$ \\
& $\left.+(3 G m \mu+2 \bar{A} \cos \chi) \cos 2\left(\chi+\psi_{0}-\bar{\psi}\right)\right\}$ \\
$Q M$ & $\frac{G \mu^{3} m^{3}}{4 \bar{L}^{3}} \sum_{i=1}^{2} p_{i} \sin ^{2} \kappa_{i}\left\{2 \bar{A} \cos \left[\chi+2\left(\psi_{0}-\psi_{i}\right)\right]\right.$ \\
& $\left.+(3 G m \mu+2 \bar{A} \cos \chi) \cos 2\left(\chi+\psi_{0}-\psi_{i}\right)\right\}$ \\
$D D$ & $\frac{\mu^{2} d_{1} d_{2}}{2 \bar{L}^{3}}\left[(3 G m \mu+4 \bar{A} \cos \chi) \beta_{D D}(2 \chi)-\bar{A} \sin \chi \frac{d \beta_{D D}(2 \chi)}{d \chi}\right]$ \\
\hline \hline
\end{tabular}

3. táblázat. A $\delta E$ változó értékei.

\begin{tabular}{ll}
\hline \hline$S O$ & nincs járulék \\
$S S$ & $-\frac{G S_{1} S_{2}}{2 c^{2} r^{3}}\left\{3 \cos \kappa_{1} \cos \kappa_{2}-\cos \gamma\right.$ \\
& $\left.-3 \sin \kappa_{1} \sin \kappa_{2} \cos 2\left(\chi+\psi_{0}-\bar{\psi}\right)\right\}$ \\
$Q M$ & $\frac{G \mu m^{3}}{2 r^{3}} \sum_{i=1}^{2} p_{i}\left[1-3 \sin ^{2} \kappa_{i} \cos ^{2}\left(\chi+\delta_{i}\right)\right]$ \\
$D D$ & $\frac{d_{1} d_{2}}{2 r^{3}}\left[\alpha_{D D}-3 \beta_{D D}(2 \chi)\right]$ \\
\hline \hline
\end{tabular}


A $\delta L$ és $\delta E$ mennyiségek (elnevezése a pálya-impulzusmomentum és az energia perturbált részeire utalnak) a SO, SS, QM és DD kölcsönhatásokra jellemző lineáris korrekciók, melyek függhetnek a $\chi$ valódi anomáliától. Ez abból adódik, hogy SS, QM és DD esetekben a pálya-impulzusmomentum nagysága nem mozgásállandó, hanem a valódi anomália harmonikus függvénye [38], [83] és [93] (a $\delta L$ és $\delta E$ mennyiségek a $\nabla$. B. táblázatokban találhatók meg(2.3) .

A (5.7) radiális egyenlet jobboldalának első 3 tagja ,,kepleri” alakú, mivel a Keplerproblémában csak ezen tagok szerepelnek, a többi tag pedig a perturbációkat tartalmazza. $\mathrm{Az}$ összes járulékra igaz az, hogy az energia mozgásállandó $(E)$, viszont az pályaimpulzusmomentum nagysága $(L)$ csak PN és SO esetben mozgásállandó, a formálisan 2 PN rendủ SS, QM és DD kölcsönhatásokra nem megmaradó mennyiség.

Ezért bevezetésre került az átlagolt pálya-impulzusmomentum nagysága $(\bar{L}=$ $\left.(1 / 2 \pi) \int_{0}^{2 \pi} L(\chi) d \chi\right)$, amely a $\chi$ valódi anomália szerinti szögátlaga a változó $L(\chi)$-nek. Az $\bar{L}$ pontos kifejezései megtalálhatók a [38], [83] és [93] forrásokban. Ily módon a perturbált mozgás $E$ energiájából és $\bar{L}$ átlagolt pálya-impulzusmomentumából definiálható az $\bar{A}$ , ,átlagolt” Laplace-Runge-Lenz vektor nagysága

$$
\bar{A}^{2}=(G m \mu)^{2}+\frac{2 E \bar{L}^{2}}{\mu}
$$

A [33] irodalomban megmutatták az általános perturbált Kepler-mozgásra, hogy a tetszőleges $r$ hatványt tartalmazó radiális egyenletekben a fordulópontokból értelmezett általános valódi és excentrikus anomáliával hogyan integrálhatók az egyenletek. Ezen általánosított paraméterezésekkel komplex változók vezethetők be, ezért a reziduumtétel használatával az integrálok egyszerübben kiértékelhetőek. A kétféle általánosított paraméterezés definíciója a következő

$$
\begin{aligned}
2 r & =\left(r_{\max }+r_{\min }\right)-\left(r_{\max }-r_{\min }\right) \cos \xi \\
\frac{2}{r} & =\left(\frac{1}{r_{\min }}+\frac{1}{r_{\max }}\right)+\left(\frac{1}{r_{\min }}-\frac{1}{r_{\max }}\right) \cos \chi
\end{aligned}
$$

ahol $r_{\max }, r_{\min }$ a radiális mozgás fordulópontjaiból $\left(\dot{r}^{2}=0\right)$ kapható apo- és pericentrum távolságok. A továbbiakban ezen (5.9, 5.10) egyenleteket használom a PN, SO, SS, QM

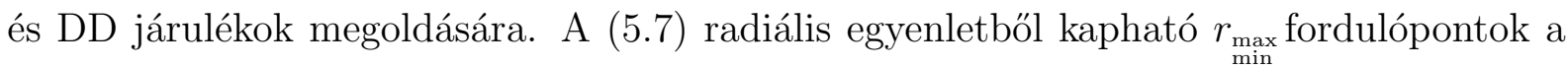

${ }^{23} \mathrm{~A}$ [35] irodalomban található 『]. táblázatban lévő az elírást itt korrigáltam (a táblázat első sorában $G \mu \bar{L} / 2 c^{2} r$ helyett a $G \mu / 2 c^{2} r$ mennyiség a helyes)

${ }^{24}$ A Laplace-Runge-Lenz vektor kepleri definíciója: $\mathbf{A}=\frac{\mathbf{p}}{\mu} \times \mathbf{L}-\frac{G m \mu}{r} \mathbf{r}$, ahol $\mathbf{p}=\frac{\partial \mathcal{L}}{\partial \dot{\mathbf{r}}}$ az általános impulzus és $\mathbf{L}=\mathbf{r} \times \mathbf{p}$ a pálya-impulzusmomentum vektor. Kepleri esetben $A=G m \mu e$, ahol $e$ az excentricitás. 
következők

$$
r_{\operatorname{mix}}=\frac{G m \mu \pm \bar{A}}{-2 E}+\delta r_{\min }^{P N}+\delta r_{\min }^{S O}+\delta r_{\min }^{S S} \underset{\min }{S S}+\delta r_{\min }^{Q M}+\delta r_{\min }^{D D}
$$

ahol az egyes járulékok

$$
\begin{aligned}
\delta r_{\operatorname{mix}}^{P N} & =(\eta-7) \frac{G m}{4 c^{2}} \pm(\eta+9) \frac{G^{2} m^{2} \mu}{8 \bar{A} c^{2}} \mp(3 \eta-1) \frac{\bar{A}}{8 \mu c^{2}}, \\
\delta r_{\max }^{S O} & =-\frac{G \mu}{2 c^{2} \overline{L A}}(\bar{A} \mp G m \mu) \sum_{i=1, j \neq i}^{2} \frac{4 m_{i}+3 m_{j}}{m_{i}} S_{i} \cos \kappa_{i}, \\
\delta r_{\max }^{S S} & =-\frac{G \mu S_{1} S_{2}}{2 c^{2} \bar{L}^{2} \bar{A}}\left[(\bar{A} \mp G m \mu) \alpha_{S S}+\bar{A} \beta_{S S}\right], \\
\delta r_{\max }^{Q M} & =\frac{G \mu^{2} m^{3}}{4 \bar{L}^{2} \bar{A}} \sum_{i=1}^{2} p_{i}\left[(\bar{A} \mp G m \mu) \alpha_{Q M}^{i}+\bar{A} \beta_{Q M}^{i}\right], \\
\delta r_{\max }^{D D} & =\frac{\mu d_{1} d_{2}}{2 \bar{L}^{2} \bar{A}}\left\{(\bar{A} \mp G m \mu) \alpha_{D D}+\bar{A} \beta_{D D}\right\},
\end{aligned}
$$

ahol beveztésre az $\alpha_{S S}, \beta_{S S}, \alpha_{Q M}^{i}, \beta_{Q M}^{i}$ és $\alpha_{D D}$ mennyiségek, melyek a spinek és a mágneses dipólmomentumok geometriáját leíró szögekkel $\left(\kappa_{i}, \gamma, \psi_{i}, \psi_{0}, \alpha_{i}\right.$ és $\left.\beta_{i}\right)$ adhatók

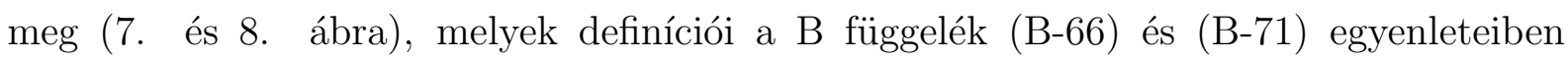
megtalálhatók. A (5.10) és (5.प) paraméterezések megadhatók a radiális pályaelemekkel, vagyis a fél nagytengellyel és excentricitással

$$
\begin{aligned}
& r(\xi)=a_{r}\left(1-e_{r} \cos \xi\right) \\
& r(\chi)=\frac{a_{r}\left(1-e_{r}^{2}\right)}{1+e_{r} \cos \chi} .
\end{aligned}
$$

Látható, hogy ez formálisan megegyezik a (3.4.3) kepleri pálya paraméterezésével, ellenben itt az $a_{r}$ a fél nagytengely és az $e_{r}$,,radiális" excentricitás tartalmazza a lineáris perturbációkat. A $\xi$ excentrikus anomália azonos a Damour-Deruelle leírásban használt u

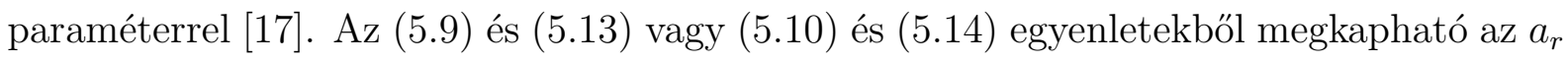
fél nagytengely és az $e_{r}$,,radiális" excentricitás összefüggései a fordulópontokból definiált $r_{\min }$ paraméterekkel

$$
a_{r}=\frac{r_{\max }+r_{\min }}{2}, \quad e_{r}=\frac{r_{\max }-r_{\min }}{r_{\max }+r_{\min }}
$$

A (5.12) felhasználásával az $a_{r}$ és $e_{r}$ radiális pályaelemekre a következők kaphatók

$$
\begin{aligned}
& a_{r}=\frac{G m \mu}{-2 E}+a_{r}^{P N}+a_{r}^{S O}+a_{r}^{S S}+a_{r}^{Q M}+a_{r}^{D D}, \\
& e_{r}=\frac{\bar{A}}{G m \mu}+e_{r}^{P N}+e_{r}^{S O}+e_{r}^{S S}+e_{r}^{Q M}+e_{r}^{D D},
\end{aligned}
$$


ahol az $e_{r}$ és $a_{r}$ korrekció a B függelék (B-62) és (B-63) egyenleteiben találhatók meg. A két anomália összefüggése a (5.9) és (5.5.3) paraméterezések alapján hasonló alakú, mint a nulladrendű kepleri pálya esetében

$$
\begin{aligned}
\tan \frac{\xi}{2} & =\sqrt{\frac{1-e_{r}}{1+e_{r}}} \tan \frac{\chi}{2} \\
\sin \xi & =\frac{\sqrt{1-e_{r}^{2}} \sin \chi}{1+e_{r} \cos \chi}
\end{aligned}
$$

Megjegyzendő, hogy Damour és Deruelle által használt 1 PN rendű mozgásleírásban [17] a valódi anomália másfajta kiterjesztése szerepel, amely nem azonos az itt szereplő fordulópontokból értelmezett $\chi$ valódi anomáliával.

\subsection{Radiális egyenlet megoldása}

A továbbiakban a klasszikus Kepler-problémában eljárt módon oldható meg a radiális mozgás, vagyis a radiális egyenlet időfüggése átírható a paraméterezésekben szereplő valódi anomália függésére. Az egyszerüsítés miatt a (5.10) általánosított valódi anomália paraméterezést a következő alakban érdemes használni

$$
\frac{2}{r}=r_{P}+r_{M} \cos \chi
$$

ahol az $r_{P}=\left(r_{\max }^{-1}+r_{\min }^{-1}\right)$ és $r_{M}=\left(r_{\min }^{-1}-r_{\max }^{-1}\right)$ a bevezetett segédmennyiségek, melyek a (5.T2) fordulópontokból számolhatók ki lineáris rendig, ezek formálisan

$$
r_{P}=\frac{2 G m \mu^{2}}{\bar{L}^{2}}+\delta Q, \quad r_{M}=\frac{2 \bar{A} \mu}{\bar{L}^{2}}+\delta P,
$$

ahol bevezetésre kerültek a $\delta P$ és $\delta Q$ rövidített jelölések, amelyek tartalmazzák a korábban felsorolt fizikai paramétereitől függő lineáris perturbációkat (田. 罒. táblázatok). Ezek

4. táblázat. A $\delta P$ mennyiség járulékai

$$
\begin{array}{ll}
\hline \hline P N & -\frac{G m \mu^{2}}{c^{2} \bar{L}^{4}}\left[\bar{A}^{2}(\eta-2)-4 G^{2} m^{2} \mu^{2}\right] \\
S O & -\frac{G \mu^{3}}{2 c^{2} \bar{L}^{5}} \sum_{i=1, j \neq i}^{2} \frac{4 m_{i}+3 m_{j}}{m_{i}} S_{i} \cos \kappa_{i}\left(\bar{A}^{2}+3 G^{2} m^{2} \mu^{2}\right) \\
S S & \frac{G \mu^{3} S_{1} S_{2}}{2 c^{2} \bar{L}^{6}}\left[\alpha_{S S}\left(\bar{A}^{2}+3 G^{2} m^{2} \mu^{2}\right)+\beta_{S S}\left(\bar{A}^{2}+G^{2} m^{2} \mu^{2}\right)\right] \\
Q M & -\frac{G m^{3} \mu^{4}}{4 \bar{L}^{6}} \sum_{i=1}^{2} p_{i}\left[\alpha_{Q M}^{i}\left(\bar{A}^{2}+3 G^{2} m^{2} \mu^{2}\right)+\beta_{Q M}^{i}\left(\bar{A}^{2}+G^{2} m^{2} \mu^{2}\right)\right] \\
D D & -\frac{\mu^{3} d_{1} d_{2}}{2 \bar{L}^{6}}\left[\alpha_{D D}\left(\bar{A}^{2}+3 G^{2} m^{2} \mu^{2}\right)+\beta_{D D}\left(\bar{A}^{2}+G^{2} m^{2} \mu^{2}\right)\right] \\
\hline \hline
\end{array}
$$




\begin{tabular}{ll}
\hline \hline$P N$ & $-\frac{\mu}{8 c^{2} \bar{L}^{4} \bar{A}}\left[2 G^{2} m^{2} \mu^{2} \bar{A}^{2}(3 \eta-19)-G^{4} m^{4} \mu^{4}(\eta+9)+\bar{A}^{4}(3 \eta-1)\right]$ \\
$S O$ & $-\frac{G^{2} m \mu^{4}}{2 c^{2} \bar{L}^{5} \bar{A}} \sum_{i=1, j \neq i}^{2} \frac{4 m_{i}+3 m_{j}}{m_{i}} S_{i} \cos \kappa_{i}\left(3 \bar{A}^{2}+G^{2} m^{2} \mu^{2}\right)$ \\
$S S$ & $\frac{G^{2} m \mu^{4} S_{1} S_{2}}{2 c^{2} \bar{L}^{6} \bar{A}}\left[\alpha_{S S}\left(3 \bar{A}^{2}+G^{2} m^{2} \mu^{2}\right)+2 \beta_{Q M} \bar{A}^{2}\right]$ \\
$Q M$ & $-\frac{G^{2} m^{4} \mu^{5}}{4 \bar{L}^{6} \bar{A}} \sum_{i=1}^{2} p_{i}\left[\alpha_{Q M}^{i}\left(3 \bar{A}^{2}+G^{2} m^{2} \mu^{2}\right)+2 \beta_{S S}^{i} \bar{A}^{2}\right]$ \\
$D D$ & $-\frac{G m \mu^{4} d_{1} d_{2}}{2 \bar{L}^{6} \bar{A}}\left[\alpha_{D D}\left(3 \bar{A}^{2}+G^{2} m^{2} \mu^{2}\right)+2 \beta_{D D} \bar{A}^{2}\right]$ \\
\hline \hline
\end{tabular}

után a (5.7) radiális egyenlet jobboldalán lévő 3 kepleri tagból a (5.201) általánosított valódi anomália paraméterezéssel a következőt kapjukª.

$$
\frac{2 E}{\mu}+\frac{2 G m}{r}-\frac{\bar{L}^{2}}{\mu^{2} r^{2}}=\left(\frac{\bar{A}}{\bar{L}^{2}}+\frac{2 \delta Q}{\mu}\right) \bar{A} \sin ^{2} \chi-\frac{2 \bar{A}}{\mu}(\delta Q+\delta P \cos \chi)
$$

A (5.7) egyenlet ,tiszta” perturbációt (a $\delta A_{i}, \delta L$ és $\delta E$-vel arányos kifejezések) tartalmazó tagjaiban elegendő használni a (3.43) nulladrendű (kepleri) paraméterezést. Az általánosított valódi anomália (5.14) alábbi tulajdonsága

$$
\frac{d r}{d \chi}=\frac{1}{2} r_{M} r^{2} \sin \chi
$$

miatt a (5.7) radiális egyenlet baloldalán lévő időderiválás áttérhetünk a $\chi$ valódi anomália szerinti deriválásra, mint ahogy az a Kepler-probléma megoldásánál ismert. A továbbiakban kiemeljük a jobboldalon lévő ,,kepleri” $\bar{A}^{2} \sin ^{2} \chi / \bar{L}^{2}$ kifejezést, majd a gyökvonást sorfejtéssel lineáris rendig elvégezve megkapjuk a valódi anomáliában integrálandó egyenletet

$$
\begin{aligned}
\frac{d t}{d \chi}= & \frac{\mu r^{2}}{\bar{L}}\left\{1+\frac{\bar{L}^{2}}{2 \mu^{2} r^{2} \bar{A}^{2} \sin ^{2} \chi}\left[r^{2} \mu \bar{A}(\delta Q+\delta P \cos \chi)\right.\right. \\
& \left.\left.+2\left(\bar{L} \delta L+r^{2} \mu \delta E\right)+\sum_{i=0}^{3} \delta A_{i} r^{2-i}\right]\right\} .
\end{aligned}
$$

Látszólag a (5.24) egyenlet szinguláris a nevezőben lévő $\sin ^{2} \chi$ miatt a $\chi=k \pi$ (ahol $k$ egész szám) értékek esetén. Az itt fellépő szingularitások eltűntethetőek, mert bebizonyítható, hogy az általánosított $r$ paraméterezés használatával a számláló arányos lesz $\sin ^{2} \chi$-vel, vagyis az ilyen típusú radiális egyenletekben megjelenő tagok mindig regularizálhatók [33]

\footnotetext{
${ }^{25}$ Kepler-problémában a radiális egyenletből a valódi anomália paraméterezésből csak $A^{2} \sin ^{2} \chi / L^{2}$ adódik.
} 
(a következő fejezetben ezt részletesen tárgyalom). Amennyiben a $\delta P, \delta Q, \delta L$ és $\delta E$, előzőleg bevezetett mennyiségeket használjuk a különböző lineáris perturbációkra, akkor megkapjuk az explicit szingularitásmentes egyenleteket az integrálandó $d t / d \chi$-re (주)

$$
\frac{d t}{d \chi}=\frac{\mu r^{2}}{\bar{L}}+\left(\frac{d t}{d \chi}\right)_{P N}+\left(\frac{d t}{d \chi}\right)_{S O}+\left(\frac{d t}{d \chi}\right)_{S S}+\left(\frac{d t}{d \chi}\right)_{D D}+\left(\frac{d t}{d \chi}\right)_{Q M}
$$

ahol

$$
\begin{aligned}
\left(\frac{d t}{d \chi}\right)_{P N}= & -\frac{\mu r^{2}}{2 c^{2} \bar{L}^{3}}\left\{(\eta-13) G^{2} m^{2} \mu^{2}+(3 \eta-1) \bar{A}^{2}+(3 \eta-8) G m \mu \bar{A} \cos \chi\right\}, \\
\left(\frac{d t}{d \chi}\right)_{S O}= & -\frac{G \mu^{3} r^{2}}{2 c^{2} \bar{L}^{4}}(3 G m \mu+\bar{A} \cos \chi) \sum_{i=1, j \neq i}^{2} \frac{4 m_{i}+3 m_{j}}{m_{i}} S_{i} \cos \kappa_{i}, \\
\left(\frac{d t}{d \chi}\right)_{S S}= & \frac{G \mu^{3} S_{1} S_{2} r^{2}}{2 c^{2} \bar{L}^{5}}\left\{\left[G m \mu\left(3 \alpha_{S S}+2 \beta_{S S}\right)+\bar{A}\left(\alpha_{S S}+\beta_{S S}\right) \cos \chi\right]\right. \\
& \left.-\frac{2 \bar{L}^{4}}{\mu^{2} r^{2} \bar{A}} \sin \kappa_{1} \sin \kappa_{2} \cos \left[\chi+2\left(\psi_{0}-\bar{\psi}\right)\right]\right\} \\
\left(\frac{d t}{d \chi}\right)_{Q M}= & -\frac{G m^{3} \mu^{4} r^{2}}{4 \bar{L}^{5}} \sum_{i=1}^{2} p_{i}\left\{\left[G m \mu\left(3 \alpha_{Q M}^{i}+2 \beta_{Q M}^{i}\right)+\bar{A}\left(\alpha_{Q M}^{i}+\beta_{Q M}^{i}\right) \cos \chi\right]\right. \\
& \left.-\frac{2 \bar{L}^{4}}{\mu^{2} r^{2} \bar{A}} \sin ^{2} \kappa_{i} \cos \left[\chi+2\left(\psi_{0}-\psi_{i}\right)\right]\right\} \\
= & -\frac{\mu^{3} d_{1} d_{2} r^{2}}{2 \bar{L}^{5}}\left\{\left[G m \mu\left(3 \alpha_{D D}+2 \beta_{D D}\right)+\bar{A}\left(\alpha_{D D}+\beta_{D D}\right) \cos \chi\right]\right. \\
\left(\frac{d t}{d \chi}\right)_{D D} & \left.+\frac{2 \bar{L}^{4}}{\mu^{2} r^{2} \bar{A}} \cos \left[\chi+2\left(\psi_{0}-\bar{\psi}\right)\right]\right\} .
\end{aligned}
$$

Ezen egyenletek integrálásából megkapható a radiális mozgás időfüggése, amelyet az égi mechanikában Kepler-egyenletnek neveznek.

\subsection{SSC invariancia}

„A spin-pálya kölcsönhatás" címü fejezetben az SSC I és SSC III mértékekben a forgó részecske mozgásegyenletének levezetését mutattam be a Mathisson-Papapetrouegyenletek segítségével. A továbbiakban a kompakt kettős rendszerek esetén vizsgálom meg a spin-pálya kölcsönhatás SSC függését a mozgásállandók segítségével. Ehhez először felírom az irodalomban ismert gyorsulások Lagrange-függvényeit, majd ebből

\footnotetext{
${ }^{26} \mathrm{~A}$ [35] irodalomban szereplő $(d t / d \chi)_{P N}$ és $(d t / d \chi)_{S O}$ járulékokban lévő elírásokat javítottam, melyek itt helyesen találhatóak meg (az eltérés PN-ben egy globális ,,--" előjel, illetve a SO-ban egy $\mu / \bar{L}$ szorzó).
} 
meghatározom a mozgásállandókat.

A 3 SSC mértékben a gyorsulások az alábbiak [36]

$$
\begin{aligned}
\mathbf{a} & =-\frac{G m}{r^{3}} \mathbf{r}+\mathbf{a}_{S O}^{I, I I, I I I}, \\
\mathbf{a}_{S O}^{I} & =\frac{G}{c^{2} r^{3}}\left\{\frac{6}{r^{2}} \mathbf{r}[(\mathbf{r} \times \mathbf{v}) \cdot(\mathbf{S}+\boldsymbol{\sigma})]-\mathbf{v} \times(4 \mathbf{S}+3 \boldsymbol{\sigma})+\frac{3 \dot{r}}{r} \mathbf{r} \times(2 \mathbf{S}+\boldsymbol{\sigma})\right\}, \\
\mathbf{a}_{S O}^{I I} & =\frac{G}{c^{2} r^{3}}\left\{\frac{3}{2 r^{2}} \mathbf{r}[(\mathbf{r} \times \mathbf{v}) \cdot(4 \mathbf{S}+3 \boldsymbol{\sigma})]-\mathbf{v} \times(4 \mathbf{S}+3 \boldsymbol{\sigma})+\frac{3 \dot{r}}{2 r} \mathbf{r} \times(4 \mathbf{S}+3 \boldsymbol{\sigma})\right\}, \\
\mathbf{a}_{S O}^{I I I} & =\frac{G}{c^{2} r^{3}}\left\{\frac{3}{r^{2}} \mathbf{r}[(\mathbf{r} \times \mathbf{v}) \cdot(2 \mathbf{S}+\boldsymbol{\sigma})]-\mathbf{v} \times(4 \mathbf{S}+3 \boldsymbol{\sigma})+\frac{6 \dot{r}}{r} \mathbf{r} \times(\mathbf{S}+\boldsymbol{\sigma})\right\}
\end{aligned}
$$

Ezen gyorsulásokhoz a következő Lagrange-függvények származtathatóak

$$
\begin{aligned}
\mathcal{L} & =\frac{\mu \mathbf{v}^{2}}{2}+\frac{G m \mu}{r}+\mathcal{L}_{S O}^{I, I I, I I I}, \\
\mathcal{L}_{S O}^{I} & =\frac{2 G \mu}{c^{2} r^{3}} \mathbf{v} \cdot[\mathbf{r} \times(\mathbf{S}+\boldsymbol{\sigma})]+\frac{\mu}{2 c^{2} m} \mathbf{v} \cdot(\mathbf{a} \times \boldsymbol{\sigma}), \\
\mathcal{L}_{S O}^{I I} & =\frac{G \mu}{2 c^{2} r^{3}} \mathbf{v} \cdot[\mathbf{r} \times(4 \mathbf{S}+3 \boldsymbol{\sigma})], \\
\mathcal{L}_{S O}^{I I I} & =\frac{G \mu}{c^{2} r^{3}} \mathbf{v} \cdot[\mathbf{r} \times(2 \mathbf{S}+\boldsymbol{\sigma})]-\frac{\mu}{2 c^{2} m} \mathbf{v} \cdot(\mathbf{a} \times \boldsymbol{\sigma}),
\end{aligned}
$$

amely alapján az SSC I és III mértékekben a $\mathcal{L}_{S O}^{I, I I, I I I}$ tartalmaz gyorsulást, míg az SSC II mértékben nem. Látható még, hogy ha a Lagrange-függvényekben használjuk a newtoni gyorsulás kifejezését, $\left(\mathbf{a}_{N}=-\left(G m / r^{3}\right) \mathbf{r}\right)$ akkor mindhárom $\mathcal{L}_{S O}^{I, I I, I I I}$ azonos lesz az SSC II-ben felírt $\mathcal{L}_{S O}^{I I}$-val [35]. A gyorsulásfüggo” $\mathcal{L}_{S O}$ miatt az általánosított Euler-Lagrange egyenleteket kell használni, melyek a következők

$$
\frac{\partial \mathcal{L}}{\partial \mathbf{r}}-\frac{d}{d t} \frac{\partial \mathcal{L}}{\partial \mathbf{v}}+\frac{d^{2}}{d t^{2}} \frac{\partial \mathcal{L}}{\partial \mathbf{a}}=0
$$

Így megkapható az energia és az impulzusmomentum-vektor [92]

$$
\begin{aligned}
& E=\mathbf{p} \cdot \mathbf{v}+\mathbf{q} \cdot \mathbf{a}-\mathcal{L} \\
& \mathbf{L}=\mathbf{r} \times \mathbf{p}+\mathbf{v} \times \mathbf{q}
\end{aligned}
$$

ahol $\mathbf{p}=\partial \mathcal{L} / \partial \mathbf{v}-\dot{\mathbf{q}}$ az általános impulzusvektor és $\mathbf{q}=\partial \mathcal{L} / \partial \mathbf{a}$ egy bevezetett mennyiség (amely csak SSC I és SSC III esetben létezik). Az (5.30) egyenlet alapján az SSC-függo” SO energiákra a következőket kapjuk 


$$
\begin{aligned}
E^{I, I I, I I I} & =\frac{\mu v^{2}}{2}-\frac{G m \mu}{r}+E_{S O}^{I, I I, I I I} \\
E_{S O}^{I} & =\frac{G(\mathbf{L} \cdot \boldsymbol{\sigma})}{c^{2} r^{3}} \\
E_{S O}^{I I} & =0 \\
E_{S O}^{I I I} & =-\frac{G(\mathbf{L} \cdot \boldsymbol{\sigma})}{c^{2} r^{3}}
\end{aligned}
$$

amelyből látható, hogy SSC II mértékben az energiának nincs SO járuléka, ezért ebben a mértékben egyszerübbek az egyenletek.

Az (5.3]) alapján a SO pálya-impulzusmomentum vektorok a következők lesznek

$$
\begin{aligned}
\mathbf{L}^{I, I I, I I I} & =\mu \mathbf{r} \times \mathbf{v}+\mathbf{L}_{\mathbf{S O}}^{I, I I, I I I} \\
\mathbf{L}_{\mathbf{S O}}^{I} & =\frac{\mu}{c^{2} m}\left\{\frac{G m}{r^{3}}[\mathbf{r} \times(\mathbf{r} \times(2 \mathbf{S}+\boldsymbol{\sigma}))]-\frac{1}{2}[\mathbf{v} \times(\mathbf{v} \times \boldsymbol{\sigma})]\right\}, \\
\mathbf{L}_{\mathbf{S O}}^{I I} & =\frac{G \mu}{2 c^{2} r^{3}} \mathbf{r} \times[\mathbf{r} \times(4 \mathbf{S}+3 \boldsymbol{\sigma})], \\
\mathbf{L}_{\mathbf{S O}}^{I I I} & =\frac{\mu}{c^{2} m}\left\{\frac{2 G m}{r^{3}}[\mathbf{r} \times(\mathbf{r} \times(\mathbf{S}+\boldsymbol{\sigma}))]+\frac{1}{2}[\mathbf{v} \times(\mathbf{v} \times \boldsymbol{\sigma})]\right\}
\end{aligned}
$$

Könnyen, belátható, hogy az $E$ energia és az $L$ (az $\mathbf{L}$ pálya-impulzusmomentum nagysága) megmaradó mennyiségek mindegyik SSC mértékben. Az (5.32) és (5.3.3) egyenletekben az $\mathbf{r}$ és $\mathbf{v}$ vektorok polárkoordinátákkal való megadását használva felírhatók a radiális egyenletek

$$
\begin{aligned}
\dot{r}^{2} & =\frac{2 E}{\mu}+\frac{2 G m}{r}-\frac{L^{2}}{\mu^{2} r^{2}}+\left(\dot{r}^{2}\right)^{I, I I, I I I}, \\
\left(\dot{r}^{2}\right)^{I} & =-\frac{2 G(2 \mathbf{L} \cdot \mathbf{S}+\mathbf{L} \cdot \boldsymbol{\sigma})}{c^{2} \mu r^{3}}+\frac{2 E(\mathbf{L} \cdot \boldsymbol{\sigma})}{c^{2} m \mu^{2} r^{2}}, \\
\left(\dot{r}^{2}\right)^{I I} & =-\frac{G(4 \mathbf{L} \cdot \mathbf{S}+3 \mathbf{L} \cdot \boldsymbol{\sigma})}{c^{2} \mu r^{3}}, \\
\left(\dot{r}^{2}\right)^{I I I} & =-\frac{2 G(2 \mathbf{L} \cdot \mathbf{S}+2 \mathbf{L} \cdot \boldsymbol{\sigma})}{c^{2} \mu r^{3}}-\frac{2 E(\mathbf{L} \cdot \boldsymbol{\sigma})}{c^{2} m \mu^{2} r^{2}}
\end{aligned}
$$

Megfigyelhető, hogy az SSC II mértékben a perturbált mennyiségek a $(4 \mathbf{L} \cdot \mathbf{S}+3 \mathbf{L} \cdot \boldsymbol{\sigma})$ kifejezéssel arányosak, míg a többi mértékben nincs ilyen ,,szimmetria”. Az egyes SSC mértékek közti transzformáció a következő (amely a Mathisson-Papapetrou egyenleteknél az abszolút koordinátákkal megadott transzformációból (4.70) is könnyen látható)

$$
\mathbf{r}^{I I}=\mathbf{r}^{I}+\frac{\mathbf{v} \times \boldsymbol{\sigma}}{2 c^{2} m}
$$


$\mathrm{Az}(5.32)$ és az (5.3.3) egyenletekben az (5.37) transzformáció használatával belátható, hogy a különböző SSC mértékekben lévő koordinátarendszerek átírhatók egymásba $(\text { Appendix })^{\mathbb{Z}]}$.

Megmutatták, hogy két különböző SSC-ben számolva a SO energia- és impulzusmomentum-veszteségeit egy periódusra átlagolva megegyeztek [94], [92], vagyis a gravitációs sugárzásból adódó fizikai mennyiségek függetlenek az SSC mértéktől.

\subsection{Kepler-egyenlet}

A perturbálatlan Kepler-egyenletnek nem létezik zárt alakban felírható megoldása a transzcendens tulajdonsága miatt, ezért az égi mechanikában jól ismert Fourier-Bessel sorfejtés segítségével írható fel a megoldása sor alakban. Ezzel a sorfejtéssel adható meg az explicit radiális mozgás időbeli fejlődése ( [63] $]$ ).

A radiális mozgás időfüggését a (5.25) egyenletek integrálásából kapjuk, melynek során a következő alakú integrálok nyerhetők

$$
\begin{aligned}
\int \frac{d \chi}{\left(r_{P}+r_{M} \cos \chi\right)^{2}} & =\frac{r_{P M}^{-1} r_{M} \sin \chi}{\left(r_{P}+r_{M} \cos \chi\right)}+\frac{2 \arctan \left(\sqrt{\frac{r_{P}-r_{M}}{r_{P}+r_{M}}} \tan \frac{\chi}{2}\right)}{r_{P M}^{3 / 2} r_{P}^{-1}} \\
\int \frac{d \chi \cos \chi}{\left(r_{P}+r_{M} \cos \chi\right)^{2}} & =\frac{r_{P M}^{-1} r_{P} \sin \chi}{\left(r_{P}+r_{M} \cos \chi\right)}-\frac{2 \arctan \left(\sqrt{\frac{r_{P}-r_{M}}{r_{P}+r_{M}}} \tan \frac{\chi}{2}\right)}{r_{P M}^{3 / 2} r_{M}^{-1}}
\end{aligned}
$$

ahol $r_{P M}=r_{P}^{2}-r_{M}^{2}$. A $d t / d \chi$ egyenletek a $\chi$ valódi anomáliában történő integrálásának eredménye meglehetősen bonyolult, mivel megjelennek $\arctan [C \tan (\chi / 2)]$ vel arányos kifejezések (hasonlóan mint a Kepler-problémában). Melyeket célszerü a (5.18) excentrikus anomália paraméterezéssel átírni

$$
\xi=\arctan \left(\sqrt{\frac{r_{P}-r_{M}}{r_{P}+r_{M}}} \tan \frac{\chi}{2}\right)
$$

amely lényegesen egyszerüsíti a eredmények szerkezetét ${ }^{\text {खृष }}$.

A (5.18), (5.19) egyenleteket felhasználva, megkapjuk a radiális mozgásnak az explicit

\footnotetext{
${ }^{27}$ Ha kiemelten az PN és SO járulékokat tárgyalom, akkor az $\bar{L}$ és $\bar{A}$ pálya-impulzusmomentum és Laplace-Runge-Lenz vektor nagyságairól elhagyom a felülvonás jelölést, utalva ezzel arra, hogy ezen esetekben $L$ és $A$ mozgásállandó (tehát az átlagolt $\bar{L}$ és $\bar{A}$ bevezetése SS, QM és DD járulékok miatt kell csak).

${ }^{28} \mathrm{~A}$ (5.38)-ban szereplő mennyiségek az általánosított excentrikus és valódi anomália közötti (5.3.9) összefüggés alapján rendre $\left(r_{P} \xi-r_{M} \sin \xi\right) r_{P M}^{-3 / 2}$ és $\left(-r_{M} \xi+r_{P} \sin \xi\right) r_{P M}^{-3 / 2}$ kifejezésekre egyszerüsíthetők.
} 
időfüggését, vagyis az általánosított Kepler-egyenletet

$$
\begin{aligned}
n\left(t-t_{0}\right)= & \xi-e_{t} \sin \xi+f_{t} \sin \left[\chi+2\left(\psi_{0}-\bar{\psi}\right)\right] \\
& +\sum_{i=1}^{2} f_{t}^{i} \sin \left[\chi+2\left(\psi_{0}-\psi_{i}\right)\right]
\end{aligned}
$$

amely figyelembe veszi a kompakt kettős rendszer véges méretéből adódó effektusokat, úgy mint a testek forgását, a tömeg kvadrupólmomentumát és a mágneses dipólmomentumát. Fontos kiemelni, hogy a Kepler-egyenletben szereplő $n=2 \pi / T$ középmozgás pályaelem csak 1 PN korrekciót tartalmaz, mely a következőképpen néz ki

$$
n=\frac{1}{G m}\left(\frac{-2 E}{\mu}\right)^{3 / 2}\left[1-(\eta-15) \frac{E}{4 c^{2} \mu}\right] \text {. }
$$

Tehát a 2 PN rendig tekintett véges méretből származó perturbációk (SO, SS, QM és DD) nem befolyásolják a $T$ pálya periódusidejét ellentétben a tisztán 2 PN rendet tartalmazó Kepler-egyenlettel, ahol a pálya periódusidejének 2 PN rendü járuléka van [18]. A (5.40) Kepler-egyenlet a $\psi_{i}, \psi_{0}$ korábban bevezetett azimutális szögeket (廿. ábra) és az $e_{t}, f_{t}$ és $f_{t}^{i}$ pályaelemeket tartalmazza, melyek közül az $e_{t}$-t az ,,idö-excentricitás"-nak nevezzük a már korábban is ismert tisztán PN rendű Kepler-egyenlet alapján, melyet Damour és Deruelle írt fel. [[7]]. Az $e_{t}$ pályaelemet az előző járulékok esetén az alábbiak szerint lehet felírni

$$
e_{t}=\frac{\bar{A}}{G m \mu}+e_{t}^{P N}+e_{t}^{S O}+e_{t}^{S S}+e_{t}^{Q M}+e_{t}^{D D},
$$

ahol az $e_{t}$ korrekciói a $\mathrm{B}$ függelék (B-64) egyenleteiben találhatók meg. A 2 PN rendü SS, DD és QM miatt fellépő $f_{t}, f_{t}^{i}$ pályaelemek pedig az alábbiak szerint adhatók meg

$$
\begin{aligned}
f_{t} & =f_{t}^{S S}+f_{t}^{D D}, \\
f_{t}^{S S} & =-\left(\frac{-2 E}{\mu}\right)^{3 / 2} \frac{\mu S_{1} S_{2}}{c^{2} m \overline{A L}} \sin \kappa_{1} \sin \kappa_{2}, \\
f_{t}^{D D} & =\left(\frac{-2 E}{\mu}\right)^{3 / 2} \frac{\mu d_{1} d_{2}}{G m \overline{A L}}, \\
f_{t}^{i} & =\left(\frac{-2 E}{\mu}\right)^{3 / 2} \frac{m^{2} \mu^{2}}{2 \overline{A L}} p_{i} \sin ^{2} \kappa_{i} .
\end{aligned}
$$

Megállapítható még, hogy a Kepler-egyenlet PN és SO esetben hasonló alakú mint a nulladrendü Kepler egyenlet, mivel a $1 \mathrm{PN}$ és SO járulékok csak $n$ és $e_{t}$ pályaelemekben

\footnotetext{
${ }^{29} \mathrm{Az} \quad n$ középmozgás ,pályaelem” kifejezhető az $a_{r}$ pályaelemmel a következőképpen $n=$ $\frac{(G m)^{1 / 2}}{a^{3 / 2}}\left[1+(2 \eta-11) \frac{G m}{4 c^{2}}\right]$ így az égi mechanikában csak akkor ,,pályaelem” ha a $a_{r}$ fél nagytengely nincs a 6 pályelem között [67].
} 
szerepelnek.

Összehasonlítva a tisztán 2 PN rendü (5. (1) és a korábban tárgyalt fizikai jellemzőkből adódó szintén 2 PN rendü (5.40) Kepler-egyenleteket, kiderül, hogy 1 PN rendben megegyeznek. A (5.]) Kepler-egyenletben használt $v$ paraméterezés a kepleri valódi anomáliának egy ,,másfajta” általánosítása, amely nem azonos a (5.14) paraméterezésben szereplő általánosított $\chi$ valódi anomáliával. Az 1 PN rendben számolt fordulópontok (5.10) felhasználásával az $r(\chi)$ és a [17] irodalomban használt $r(v)$ paraméterezések segítségével megadható a két nem-kepleri anomália közötti transzformáció

$$
\tan \frac{\chi}{2}=\left[1-\frac{G m \mu}{4 c^{2} \bar{L}^{2} \bar{A}}\left(G^{2} m \mu^{3}+\frac{12 E \bar{L}^{2}}{\mu}\right)\right] \tan \frac{v}{2} .
$$

Az általunk megadott (5.40) Kepler-egyenlettel lehetőség nyílik olyan kettős rendszerek időbeli leírására, melyekben a testek spinnel, tömeg kvadrupólmomentummal és mágneses dipólmomentummal rendelkeznek. Tehát a radiális mozgás ismerete elengedhetetlen a gravitációs hullámok keletkezésének fizikájában.

\subsection{Körpálya határeset}

A gravitációs sugárzás hatására a kötött elliptikus pályák fél nagytengelye és excentricitása csökken, amely a pálya cirkularizációjához vezet [14]. Emiatt érdekes megvizsgálni, hogy az előző fejezetben tárgyalt perturbált radiális mozgásnak milyen körpálya határeset felel meg. Az irodalomban többféle körpálya határátmenet definíció létezik, melyek a kepleri mozgásra ekvivalensek.

Ismert, hogy spinekkel rendelkező kettős rendszernek (SO, SS kölcsönhatás), nem létezik körpálya határátmenete, pontosabban az egzakt körpálya feltétel $(\dot{r}=0)$ nem teljesül a SS kölcsönhatásból adódó (4.73) spinprecesszió miatt [36]. Ezért használják az átlagolt körpálya definíciót, amelyet Barker és O’Connell vezetett be [[75], amely egy pálya periódusidőre átlagolja a spinprecessziós egyenleteket (4.75).

\subsubsection{Kepleri körpálya}

A nulladrendű (perturbálatlan) radiális egyenlet, amely a következőképpen néz ki (ebben az esetben $L$ mozgásállandó)

$$
\dot{r}^{2}=\frac{2 E}{\mu}+\frac{2 G m}{r}-\frac{L^{2}}{\mu^{2} r^{2}}
$$




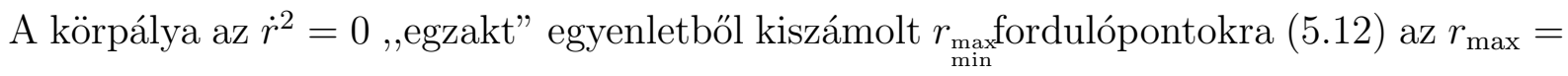
$r_{\min }=r_{N}$ feltétel a kepleri körpálya sugarát adja meg

$$
r_{N}=\frac{G m \mu}{-2 E}
$$

Az $r_{\max }=r_{\min }$ azt is jelenti, hogy a $\dot{r}^{2}=0$ egyenlet diszkriminánsa eltünik. A (5.45) körpálya sugarát behelyettesítjük a radiális egyenletbe, megkapjuk az energia és a pályaimpulzusmomentum nagysága közötti összefüggést

$$
E=-\frac{G^{2} m^{2} \mu^{3}}{2 L^{2}}
$$

amelyből kiderül, hogy az $E$ és az $L$ nem független mozgásállandók körpálya esetben. Az $r_{\max }=r_{\min }$ feltételből adódik, hogy az $A$ Laplace-Runge-Lenz vektor nagysága nulla lesz (5.8), amely ekvivalens az excentricitás eltűnésével $(e=A / G m \mu)$.

A következőkben a $V_{\text {eff }}$ effektív potenciál bevezetésével definiálom a körpálya feltételét, az (5.44) radiális egyenlet átírható a következőképpen

$$
\frac{\mu \dot{r}^{2}}{2}+V_{e f f}=E
$$

ahol a $V_{\text {eff }}=-G m \mu / r+L^{2} / 2 \mu r^{2}$. Ebben az esetben a körpályát a $d V_{e f f} / d t=0$ feltételből adhatjuk meg, amely az alábbi körpálya sugárhoz vezet

$$
r_{N}^{*}=\frac{L^{2}}{G m \mu^{2}} .
$$

Látható, hogy az (5.45) és (5.48) alakú sugarak között az (5.46) körpályára vonatkozó energiafeltétel teremt kapcsolatot.

Összefoglalva az (5.44) radiális egyenlet körpálya feltételeit, amely az alábbi rövidített jelöléssel adható meg

$$
\dot{r}^{2}=A+\frac{B}{r}+\frac{C}{r^{2}},
$$

ahol az együtthatókra az $A, B$ és $C$ jelöléseket vezettem be. Az előzőek alapján meghatározhatóak az egymással ekvivalens kepleri körpálya határfeltételei:

$\mathcal{I}$. Fordulópontok azonosak $\left(r_{\max }=r_{\min }=r_{N}\right)$, vagyis a pálya minden egyes pontja ,,fordulópont”. Az (5.4.9) alapján $r_{0}=-B /(2 A)$.

II . Diszkrimináns eltünése $\left(B^{2}-4 A C=0\right)$, ez a (5.46) körpályás energiafeltétel.

III. A bevezetett $V_{\text {eff }}$ effektív potenciálnak szélsőértéke van $\left(d V_{\text {eff }} / d r=0\right)$, vagyis formálisan $B / 2 r^{2}+C / r^{3}=0$, tehát $r_{N}^{*}=-2 C / B$ adódik. 
IV. Az excentricitás eltünése $\left(e^{2}=0\right)$, amelyből következik, hogy az (5.T3) és az (5.14) paraméterezéseknél az $r$ állandó.

Az előzőekben vizsgált lineáris perturbációk közül PN és SO esetekben is teljesülnek a kepleri körpálya határfeltételei $\mathcal{I}$.-IV ., melyet a „Perturbált körpálya” címü fejezetben mutatok be. A SS, QM és DD esetekben nem létezik egzakt körpálya, ezért a körpálya definíció kiterjesztésre van szükség, melyet a „Kvázikörpálya” című fejezetben tárgyalom.

\subsubsection{Perturbált körpálya}

Ebben a fejezetben megmutatom, hogy a kepleri körpályánál megismert feltételek miért alkalmazhatóak a PN és a SO lineáris perturbációkra is. Ennek első lépése, hogy a (5.49) radiális egyenletet egy $D / r^{3}$ állandó együtthatójú lineáris perturbációval $(D \approx$ $\mathcal{O}\left(1 / c^{2}\right)$, amely Schwarzschild esetben $D=2 G m L^{2} / \mu^{2} c^{2}$ és SO SSC II esetében $D=$ $-G\left[(4(\mathbf{L} \cdot \mathbf{S})+3(\mathbf{L} \cdot \sigma)] / c^{2} \mu\right)$ egészítjük ki

$$
\dot{r}^{2}=A+\frac{B}{r}+\frac{C}{r^{2}}+\frac{D}{r^{3}},
$$

ahol $A, B, C$ együtthatók szintén állandók és perturbációt tartalmazhatnak.

A (5.50) egyenletből az $\dot{r}=0$ feltétel felhasználásával megadhatók a következő formális fordulópontok

$$
r_{\min }=\frac{-B \mp \sqrt{B^{2}-4 A C}}{2 A} \mp \frac{D\left(B \mp \sqrt{B^{2}-4 A C}\right)}{2 C \sqrt{B^{2}-4 A C}} .
$$

Az $\mathcal{I}$. feltétel alapján definiálható a perturbált körpálya sugara a (5.5]) fordulópontjaiból $\left(r_{\max }=r_{\min }\right)$

$$
r=\frac{-B}{2 A}+\frac{D}{2 C}
$$

Látható, hogy az előző $r_{\max }=r_{\min }$ feltétel alapján az (5.5]) egyenletből a $B^{2}-4 A C$ tag eltünik, vagyis a $\mathcal{I} \mathcal{I}$. feltétel is teljesül. Például a SO kölcsönhatás esetén a (5.52) körpálya sugara az alábbi

$$
r_{N+S O}=\frac{G m \mu}{-2 E}+\frac{G \mu[(4(\mathbf{L} \cdot \mathbf{S})+3(\mathbf{L} \cdot \boldsymbol{\sigma})]}{2 c^{2} L^{2}}
$$

Az effektív potenciál szélsőértékének eltünéséből (IIII. feltétel) a következő körpálya sugár adódik ${ }^{30 .}$

$$
r^{*}=\frac{-2 C}{B}+\frac{3 D}{2 C}
$$

\footnotetext{
${ }^{30} \mathrm{Ha}$ a körpályára vonatkozó energiafeltételt akarjuk felírni, akkor célszerủ az $r^{*}$ alakban megadott sugarat használni a radiális egyenletben, mivel a $B / r$ és $C / r^{2}$ tagja kiejti az elsőrendủ járulékát $r^{*}$-nek, így a nulladrendű alak használata elegendő.
} 
amely SO-ra

$$
r_{N+S O}^{*}=\frac{L^{2}}{G m \mu^{2}}+\frac{3 G \mu[(4(\mathbf{L} \cdot \mathbf{S})+3(\mathbf{L} \cdot \boldsymbol{\sigma})]}{2 c^{2} L^{2}},
$$

A kepleri körpályához hasonlóan az (5.52) és az (5.54) kétféle alakú sugár között az energiaegyenlet teremt kapcsolatot $(\mathcal{I} \mathcal{I}$. feltétel), vagyis

$$
A=\frac{B^{2}}{4 C}\left(1+\frac{B D}{2 C^{2}}\right)
$$

A SO-ra vonatkozó körpályás energiaegyenlet a következő

$$
E=-\frac{G^{2} m^{2} \mu^{3}}{2 L^{2}}\left(1-\frac{G^{2} m \mu^{3}[(4(\mathbf{L} \cdot \mathbf{S})+3(\mathbf{L} \cdot \boldsymbol{\sigma})]}{c^{2} L^{4}}\right)
$$

Látható, hogy a $\mathcal{I} \mathcal{V}$. feltétel is teljesül, azonban itt a perturbált pályához tartozó (5.17) radiális excentricitás eltűnését $\left(e_{r}^{2}=0\right)$ kell használni. Így SO kölcsönhatásra a $A^{2} /(G m \mu)^{2}+2 E\left(G^{2} m^{2} \mu^{2}+A^{2}\right)\left[(4(\mathbf{L} \cdot \mathbf{S})+3(\mathbf{L} \cdot \boldsymbol{\sigma})] /\left(c^{2} m L^{2}\right)=0\right.$ egyenlet ekvivalens az $(5.57)$ energiaegyenlettel 30 .

\subsubsection{Kvázikörpálya}

Ebben az alfejezetben a SS, QM és DD esetekre vizsgálom a körpálya feltételét. A spinek precessziója miatt a SS, QM és DD kölcsönhatásokban nem teljesíthető az $\dot{r}^{2}=0$ egzakt körpálya határfeltétel, ezért a Kidder-féle kvázikörpálya definíciót használják, mellyel mégis meghatározható egy körpálya [36]].

A körpálya a kettős rendszer a gyorsulásának a projekcióira kirótt feltételek alapján adható meg. A kettős pályasíkjához rögzített $\left(\hat{\mathbf{L}}_{N}, \hat{\mathbf{r}}, \hat{\mathbf{L}}_{N} \times \hat{\mathbf{r}}\right)$ ortogonális bázist (az $\hat{\mathbf{L}}_{N} \times \hat{\mathbf{r}}$ sebességirányú egységvektort $\hat{\lambda}$-val jelölöm) vezetünk be, majd ebben a koordinátarendszerben definiáljuk az a gyorsulás projekcióit, melyek a következők

$$
\begin{aligned}
\hat{\mathbf{r}} \cdot \mathbf{a} & =\ddot{r}-r \omega^{2} \\
\hat{\lambda} \cdot \mathbf{a} & =r \dot{\omega}+2 \dot{r} \omega \\
\hat{\mathbf{L}}_{N} \cdot \mathbf{a} & =-r \omega\left(\hat{\lambda} \cdot \frac{d \hat{\mathbf{L}}_{N}}{d t}\right)
\end{aligned}
$$

ahol $\omega$ a pályafrekvencia, vagyis $\mathbf{v}=\dot{r} \hat{\mathbf{r}}+r \omega \hat{\lambda}$. A körpálya definíciója az (5.58)-(5.607)

\footnotetext{
${ }^{31}$ Érdekes tény, hogy ha csak az $e_{r}=0$ tekintem körpálya feltételének, akkor más körpályás energiafeltétel jön ki, mint a (5.57) egyenletben. Ez azért van, mert egy perturbatív mennyiség négyzetének lineáris sorfejtéséből adódik egy 2-es faktor (pl. $e=1-a+\varepsilon$ (ahol $\varepsilon$ egy lineáris perturbáció) akkor az $e=0$ feltételból az $a=1+\varepsilon$, míg $e^{2}=0$ feltételből $a=1+2 \varepsilon$ származik).
} 
egyenletek alapján a következő

$$
\ddot{r}=\dot{r}=\dot{\omega}=\frac{d \hat{\mathbf{L}}_{N}}{d t}=0
$$

Ezen feltétel ekvivalens a korábban bevezetett $\mathcal{I}$. $-\mathcal{I} \mathcal{V}$. feltételekkel PN és SO esetekben. $\mathrm{Az}(5.58)$ egyenlet az $\omega$ definícióját adja meg, melyek SO és SS kölcsönhatások esetén a következők

$$
\begin{aligned}
\omega^{2} & =\frac{G m}{r^{3}}+\omega_{S O}^{2}+\omega_{S S}^{2} \\
\omega_{S O}^{2} & =\frac{G}{c^{2} \mu r^{4}}[2(\mathbf{L} \cdot \mathbf{S})+3(\mathbf{L} \cdot \boldsymbol{\sigma})], \\
\omega_{S S}^{2} & =\frac{3 G S_{1} S_{2}}{c^{2} \mu r^{5}}\left[\left(\hat{\mathbf{S}}_{1} \cdot \hat{\mathbf{S}}_{1}\right)-3\left(\hat{\mathbf{r}} \cdot \hat{\mathbf{S}}_{1}\right)\left(\hat{\mathbf{r}} \cdot \hat{\mathbf{S}}_{2}\right)\right] .
\end{aligned}
$$

Az (5.5.9) és az (5.50) egyenletek további megkötéseket adnak a körpályára (pl. $d \hat{\mathbf{L}}_{N} / d t=$ 0 nem teljesül automatikusan a SO, SS, QM és DD járulékokra).

SO kölcsönhatásra alkalmazva az (5.60) feltételt az (5.50) egyenletre (a (5.5.9) automatikusan teljesül), akkor a spinek nagyságától függő feltételt kapjuk

$$
a_{1} S_{1} \sin \kappa_{1} \cos \left(\psi-\psi_{1}\right)+a_{2} S_{2} \sin \kappa_{2} \cos \left(\psi-\psi_{2}\right)=0
$$

ahol $a_{1}=4+3 \nu$ és $a_{2}=4+3 \nu^{-1}$. Ezen egyenlet hasonló a spinek csomóvonalára való vetítésére ( [92] (2.20) egyenlet), amely a következő alakú

$$
S_{1} \sin \kappa_{1} \cos \psi_{1}+S_{2} \sin \kappa_{2} \cos \psi_{2}=0
$$

SS esetben a következő két feltételt kapjuk az (5.5.9) és az (5.60 ) egyenletekből

$$
\begin{aligned}
\sin \kappa_{1} \sin \kappa_{2} \sin \left(2 \psi-\psi_{1}-\psi_{2}\right) & =0, \\
\sin \left(2 \kappa_{1}\right) \cos \left(\psi-\psi_{1}\right)+\sin \left(2 \kappa_{2}\right) \cos \left(\psi-\psi_{2}\right) & =0 .
\end{aligned}
$$

Látható, hogy az (5.65)-(5.68) feltételek, csak akkor teljesülnek, ha $\kappa_{i}=0$, vagyis a spinek merőlegesek a pályasíkra (,,elfajult eset”). Tehát a tetszőleges spinorientáció nem megengedett az (5.58)-(5.507) és az (5.57) egyenletek miatt.

A körpálya megfelelő definíciójának a megadásához a korábban bevezetett kepleri pálya átlagolás használható, mellyel már a körpályára vonatkozó (5.67) feltételek teljesülnek és így tetszőleges spingeometria tanulmányozható. Tehát az (5.58) egyenlet helyett a Kidder- 
féle kvázikörpálya definíció a következőképpen írható fel

$$
\langle\hat{\mathbf{r}} \cdot \mathbf{a}\rangle=-r \omega^{2}
$$

A SS kölcsönhatás esetén az (5.69) alapján a pályafrekvenciára a következő adódik

$$
\omega_{S S}^{2}=-\frac{3 G S_{1} S_{2}}{2 c^{2} \mu r^{5}}\left[\left(\hat{\mathbf{S}}_{1} \cdot \hat{\mathbf{S}}_{1}\right)-3\left(\hat{\mathbf{L}} \cdot \hat{\mathbf{S}}_{1}\right)\left(\hat{\mathbf{L}} \cdot \hat{\mathbf{S}}_{2}\right)\right]
$$

A SS járulékra a pillanatnyi $\left(\hat{\mathbf{r}} \cdot \mathbf{a}=-r \omega^{2}\right)$ és az átlagolt $\left(\langle\hat{\mathbf{r}} \cdot \mathbf{a}\rangle=-r \omega^{2}\right)$ határfeltételből kapott alábbi körpálya sugarak megadhatók összehasonlításképpen

$$
\begin{aligned}
r_{S S} & =r_{N}+\frac{3 G S_{1} S_{2}}{c^{2} \mu r^{5}}\left[\left(\hat{\mathbf{S}}_{1} \cdot \hat{\mathbf{S}}_{1}\right)-3\left(\hat{\mathbf{r}} \cdot \hat{\mathbf{S}}_{1}\right)\left(\hat{\mathbf{r}} \cdot \hat{\mathbf{S}}_{2}\right)\right], \\
\left\langle r_{S S}\right\rangle & =r_{N}-\frac{3 G S_{1} S_{2}}{2 c^{2} \mu r^{5}}\left[\left(\hat{\mathbf{S}}_{1} \cdot \hat{\mathbf{S}}_{1}\right)-3\left(\hat{\mathbf{L}} \cdot \hat{\mathbf{S}}_{1}\right)\left(\hat{\mathbf{L}} \cdot \hat{\mathbf{S}}_{2}\right)\right],
\end{aligned}
$$

melyek közül az $\left\langle r_{S S}\right\rangle$ tetszőleges spingeometriára érvényes, míg $r_{S S}$ csak ,elfajult” esetben létezik (ahol $r_{N}$ a korábban bevezetett kepleri sugár). Látható, hogy az átlagolás miatt az $\left\langle r_{S S}\right\rangle$ kifejezésben megjelennek a $\gamma$ és $\kappa_{i}$ relatív szögek (口. ábra), melyekkel egyszerűbben jellemezhetők a kettős rendszerek (mint a korábban megjelent $\hat{\mathbf{r}} \cdot \hat{\mathbf{S}}_{i}$ skalárszozatok). 


\section{Az általánosan perturbált radiális mozgás}

Az égi mechanika egyik legjobban tanulmányozott része a perturbált kéttest-probléma, melyekben legfóképpen a Lagrange-féle planetáris egyenleteket használják [34] a perturbációk leírására, ezek 6 pályaelemre felírt elsőrendű mozgásegyenletek. A kettős rendszer mozgását befolyásoló perturbációk jellegétől (pl. periodikus, szekuláris) függően többféle módszert használnak a planetáris egyenletek megoldására [3]].

$\mathrm{Az}$ általános perturbációk bevezetésére a Brumberg-erőt használják, amely a kettős rendszeréhez rögzített bázis egyes irányaiban vett perturbációk erőkomponenseit tartalmazzák. Így a Brumberg erő használható a PN relativisztikus korrekció és a SO kölcsönhatás [3]] megadására.

A (5.7) egyenlet alapján az általános perturbációk bevezethetők a radiális egyenletben az $r^{i}$ szerinti hatványsor alakban, így felírható egy olyan általános egyenlet, amelyben az utolsó tag a pertubációkat tartalmazza [3:3]

$$
\dot{r}^{2}=\frac{2 E}{\mu}+\frac{2 G m}{r}-\frac{\bar{L}^{2}}{\mu^{2} r^{2}}+\sum_{i=0}^{p} \frac{\varphi_{i}}{\mu^{2} r^{i}},
$$

ahol $\varphi_{i}$ állandó együtthatójú perturbációs koefficiensek.

A (6.]) alakú radiális egyenlet megoldásánál a következő szekuláris integrálok jelennek meg

$$
I(\omega, n)=\int_{0}^{T} \frac{\omega}{r^{2+n}} d t
$$

ahol $\omega$ állandó, $T$ a pálya periódusideje és $n$ tetszőleges egész szám. Megmutatták, hogy az $I(\omega, n)$ integrálok tetszőleges $n$ egész szám esetén a korábban bevezetett (5.J0) valódi és (5.9) excentrikus anomália paraméterezés segítségével kiértékelhetők [33]. Ez alapján, az $n$ hatványszám értékétől függően a valódi, vagy az excentrikus anomália paraméterezés bizonyult használhatónak. Ezen paraméterek bevezetése után, a komplex számsíkra való áttéréssel $(z=\exp (i \chi)$ és $w=\exp (i \xi))$ alkalmazható lesz a reziduum-tétel, mellyel a szekuláris integrálok lényegesen egyszerűen adhatók meg, ugyanis maximum két pólus kapható a komplex számsíkon [33]. Ezen módszerrel könnyen kiszámolhatóak a PN és SO járulékokból adódó szekuláris energia- és impulzusmomentum-veszteségek [92]

Az előző fejezetben látható volt, hogy az általam vizsgált lineáris perturbációk SS, QM és DD eseteiben $\varphi_{i}$-k nem állandók (5.7), hanem a $\chi$ valódi anomáliának a $\varphi_{i}(\chi)$ harmonikus függvényei, ezért fontos kérdés, hogy lehetséges-e általánosítani a korábbi módszert SS, QM és DD fizikailag érdekes esetekre is. 


\subsection{A módszer általánosítása}

A (6.]) egyenlet helyett egy általánosabb radiális egyenletet teszünk fel, ahol $\varphi_{i}(\chi)$ harmonikus függvényei a $\chi$ valódi anomáliának ((5.7) SS, QM és DD esetek)

$$
\dot{r}^{2}=2 \frac{E}{\mu}+2 \frac{G m}{r}-\frac{\bar{L}^{2}}{\mu^{2} r^{2}}+\sum_{i=0}^{p} \frac{\varphi_{i}(\chi)}{\mu^{2} r^{i}} .
$$

A radiális mozgás $r_{\min }$ fordulópontjait $\left(\dot{r}^{2}=0\right)$ az előző fejezetben tárgyalt módon a ([6.3) egyenletből írhatók fel, melyek az alábbiak

$$
r_{\min }=\frac{G m \mu \pm \bar{A}}{-2 E} \pm \frac{1}{2 \mu \bar{A}} \sum_{i=0}^{p} \varphi_{i}^{ \pm}\left[\frac{\mu(G m \mu \mp \bar{A})}{\bar{L}^{2}}\right]^{i-2}
$$

ahol az $\bar{A}$ a Laplace-Runge-Lenz vektor nagysága, amely az $E$ és $\bar{L}$ mozgásállandókkal adhatók meg az (5.8) egyenlet alapján. A fordulópontokban a $\varphi_{i}(\chi)$ függvény két értéket $(\chi=0, \pi)$ vehet fel, melyet a pericentrumban $\varphi_{i}^{-}$, az apocentrumban pedig $\varphi_{i}^{+}$értékkel jelölünk, vagyis

$$
\varphi_{i}^{-}=\varphi_{i}(0), \quad \varphi_{i}^{+}=\varphi_{i}(\pi)
$$

$\mathrm{Az}(5.201)$ egyenletben bevezetett valódi anomália paraméterezésben szereplő $r_{P}$ és $r_{M}$ segédmennyiségekre a (6.4) $r_{\min }$ fordulópontokból a következő adódik

$$
\begin{aligned}
& r_{P}=\frac{2 G m \mu^{2}}{\bar{L}^{2}}+\frac{1}{2 \mu \bar{A}} \sum_{i=0}^{p} \Delta_{-}^{i} \\
& r_{M}=\frac{2 \mu \bar{A}}{\bar{L}^{2}}+\frac{1}{2 \mu \bar{A}} \sum_{i=0}^{p} \Delta_{+}^{i},
\end{aligned}
$$

ahol bevezetésre került a

$$
\Delta_{ \pm}^{i}=\frac{\mu^{i}}{\bar{L}^{2 i}}\left[\varphi_{i}^{-}(G m \mu+\bar{A})^{i} \pm \varphi_{i}^{+}(G m \mu-\bar{A})^{i}\right]
$$

Így az (\$. (10) paraméterezés kifejezhető a perturbált mozgást jellemző $E, \bar{L}$ és $\bar{A}$ mozgásállandókkal 5 zz

$$
\frac{2}{r}=\frac{2 G m \mu^{2}}{\bar{L}^{2}}+\frac{1}{2 \mu \bar{A}} \sum_{i=0}^{p} \Delta_{-}^{i}+\left(\frac{2 \mu \bar{A}}{\bar{L}^{2}}+\frac{1}{2 \mu \bar{A}} \sum_{i=0}^{p} \Delta_{+}^{i}\right) \cos \chi .
$$

\footnotetext{
${ }^{32} \mathrm{Az}$ (5.8) egyenletben szereplő 3 mennyiség közül csak 2 független a mozgás folyamán (az $\mathbf{L}$ és $\mathbf{A}$ vektoroknak fontos szerepe van a Kepler-probléma rejtett szimmetriáiban, melyet elsőként Fock ismert fel 1935-ben, magyar vonatkozásban Györgyi Géza foglalkozott a szimmetriák általánosításával).
} 
Ezek segítségével a fentebb értelmezett $I(\omega, n)$ integrál (6.2) átírható a $\chi$ valódi anomália szerinti integrálásra

$$
I(\omega, n)=\int_{0}^{2 \pi} \frac{\omega}{r^{n}}\left(\frac{1}{r^{2}} \frac{d t}{d \chi}\right) d \chi
$$

Látható, hogy az $n$ egész szám előjele határozza meg, hogy melyik paraméterezést célszerü alkalmazni. A paraméterezések struktúrája (5.10), (5.9) miatt érdemes a pozitív hatványkitevős integrálban a $\chi$ valódi, míg a negatív kitevős integrálban a $\xi$ excentrikus anomáliát használni. Így a továbbiakban két esetre szétbontjuk a leírást.

\subsection{Az $n \geq 0$ eset}

Ebben a részben az általánosított $\chi$ valódi anomália paraméterezést (5.T0) használjuk az integrál kiértékeléséhez, melyet a ([6.3) egyenletben szereplő negatív hatványok miatt a következő alakban írunk fel

$$
\frac{2}{r}=\frac{1+\cos \chi}{r_{\min }}+\frac{1-\cos \chi}{r_{\max }}
$$

A (G.T0) integrandus nevezőjében lévő $r^{n}$ kifejezés az $n \geq 0$ feltétel miatt a binomiális tétel segítségével kifejthető

$$
\left[\frac{2}{r}\right]^{n}=\sum_{k=0}^{n}\left(\begin{array}{l}
n \\
k
\end{array}\right)\left(\frac{1+\cos \chi}{r_{\min }}\right)^{k}\left(\frac{1-\cos \chi}{r_{\max }}\right)^{n-k} .
$$

A $d t / d \chi=\dot{r}^{-1} d r / d \chi$ mennyiségben használjuk az $\dot{r}^{-1}$-et a (G. $)$ egyenletböl és a $d r / d \chi$ mennyiséget (amely kiszámolható a (G.]) paraméterezésből) melyekből megkapjuk a (Б.⿴囗十) integrandus zárójelében lévő kifejezést

$$
\begin{aligned}
\frac{1}{r^{2}} \frac{d t}{d \chi} & =\frac{\mu}{L}\left(1+\frac{\bar{L}^{2}}{4 \mu^{2} \bar{A}^{2} \sin ^{2} \chi} \Gamma\right) \\
\Gamma & =\sum_{i=0}^{p}\left(\Delta_{+}^{i}+\Delta_{-}^{i} \cos \chi-\frac{2 \varphi_{i}(\chi)}{r^{i}}\right) .
\end{aligned}
$$

A (6.13) egyenlet második tagjának nevezöje tartalmazza a $\sin ^{2} \chi$ kifejezést, amely látszólag szinguláris a valódi anomália $\chi=k \pi$ ( $k$ egész) értékeire. A [33] irodalomban megmutatták, hogy egy $\sin ^{2} \chi$ szorzó emelhető ki a $\Gamma$ (6.14) kifejezésből és így az $I(\omega, n)$ integrandus reguláris lesz.

A továbbiakban a $\varphi_{i}(\chi)$ perturbációs függvények a harmonikus tulajdonságuk miatt 
a következő sor alakba írhatók fel

$$
\varphi_{i}(\chi)=\sum_{j=0}^{\infty}\left(f_{i j}+g_{i j} \cos \chi\right) \sin ^{j} \chi,
$$

ahol $f_{i j}$ és $g_{i j}$ állandók, illetve a fordulópontoknál bevezetett mennyiségek

$$
\varphi_{i}^{\mp}=f_{i 0} \pm g_{i 0}
$$

A (6.15) egyenlet ekvivalens az általános Fourier-sor kifejtéssel, amely azért hasznos, mivel $j \geq 2$ esetben a $\varphi_{i}(\chi)$ függvény $\sin ^{2} \chi$-el arányos. Így a regularitáshoz csak azon eseteket kell figyelembe venni, mikor $j=0$, vagy 1 , ezért szükség van a $f_{i 0}, g_{i 0}, f_{i 1}$ és $g_{i 1}$ tagokat tartalmazó látszólag szinguláris integrálok (6.10) vizsgálatára. Algebrai eszközökkel korábban $f_{i 0}$-ra megmutatták [33], hogy reguláris lesz az integrandusban szereplő (G.14) kifejezés, amely hasonlóan belátható a $g_{i 0}$-ra is. A továbbiakban az $f_{i 1}$ és $g_{i 1}$ esetekre kell bebizonyítani a regularitás feltételét.

A (6.T2) és a fordulópontok kifejezéseinek (6.4) alkalmazásával a $\Gamma$-ban lévő tagok a következők lesznek

$$
\begin{aligned}
& \sum_{l=0}^{i}\left(\begin{array}{l}
i \\
l
\end{array}\right)(G m \mu)^{i-l} A_{0}^{l}\left[\frac{1-(-1)^{l}}{2} \sin ^{2} \chi+\Xi_{l+1}(\chi)\right], \\
\Xi_{l+1}(\chi)= & \frac{1-(-1)^{k}}{2} \cos \chi+\frac{1+(-1)^{k}}{2} \cos ^{2} \chi-\cos ^{k} \chi,
\end{aligned}
$$

ahol $\Xi_{k}(\chi)$ kifejezésről megmutatták a [3:3] irodalomban, hogy arányos $\sin ^{2} \chi$-vel, vagyis a $g_{i 0}$ tag nem ad szinguláris járulékot az $I(\omega, n)$ integrandushoz. A továbbiakban $j=1$ esetet kell megvizsgálni, ahol a $\Gamma$-ban lévő tag a következő lesz

$$
-\sum_{i=0}^{p} \frac{2\left(f_{i 1}+g_{i 1} \cos \chi\right) \sin \chi}{r^{i}}
$$

A (G.T9) mennyiségben szereplő $f_{i 1}$ és $g_{i 1}$ koefficiensek elsőrendü járulékok, ezért elegendő az $r=\left(\mu / L^{2}\right) /(G m \mu+A \cos \chi)$ kepleri valódi anomália paraméterezést használni. Ezt követően az $1 / r^{i}$ tagban a binomiális tételt alkalmazzuk, majd behelyettesítjük a $\cos ^{2} \chi=1-\sin ^{2} \chi$ azonosságot amely eredményeképp kapott tagok az $\left(1-\sin ^{2} \chi\right)^{q}$ mennyiséggel lesznek arányosak. Majd ismét binomiális tétel segítségével és a tagok csoportosításával (a $\sin ^{2} \chi$-es szorzón kívül) elérhető lesz, hogy arányosak lesznek $\sin \chi$ és $\sin \chi \cos \chi$ mennyiségekkel. Ezek alapján kapunk egy feltételt $f_{i 1}$ és $g_{i 1}$ koefficiensekre, 
mely a következő

$$
\sum_{i=0}^{p} \frac{\mu^{i}}{\bar{L}^{2 i}}(G m \mu \pm \bar{A})^{i}\left(f_{i 1} \pm g_{i 1}\right)=0
$$

amely alapján a (G.Tl) egyenlet zárójelben lévő tagja reguláris lesz minden $\chi$-re, vagyis az $I(\omega, n)$ regularitásának a feltétele hogy $\omega$ periodikus függvénye kell hogy legyen a $\chi$ valódi anomáliában.

A (6.20) feltétellel az $I(\omega, n)$ integrandus összes tagja a sin $\chi=\left(z^{2}-1\right) / 2 i z$ és cos $\chi=$ $\left(z^{2}+1\right) / 2 z$ változócserével átírható polinomok összegére $n \geq 0$ esetben, amely lehetővé teszi (a [33] irodalom alapján), hogy csak egy pólus legyen az origóban, amely alapján a következő tételt állapíthatjuk meg:

Tétel 1.: A teljes perturbált Kepler-mozgást a (5.22) radiális egyenlet jellemzi, ahol a $\varphi_{i}(\chi)$ periódikus perturbációk, melyek a (6.15) alakú Fouriersorba írhatók. Ha a $\varphi_{i}(\chi)$-ban lévö koefficiensekre teljesül a(6.20) feltétel, akkor egy tetszőleges $\omega$ periódikus függvényre az $I(\omega, n \geq 0)$ integrál értéke megegyezik a $z=\exp (i \chi)$ változócserével kapott komplex számsík origójában vett reziduumával.

\subsection{Az $n<0$ eset}

Az $n<0$ esetben az excentrikus anomália paraméterezés használható (5.9), melyet a következőképpen írunk fel

$$
2 r=(1+\cos \xi) r_{\min }+(1-\cos \xi) r_{\max }
$$

A fenti tétel kiterjesztése ezen esetre analóg módon történik, ugyanis a kétféle parametrizáció közti relációk az alábbiak

$$
\begin{aligned}
\cos \chi & =\frac{G m \mu \cos \xi-\bar{A}}{G m \mu-\bar{A} \cos \xi}, \\
\sin \chi & =\frac{\left(-2 E \bar{L}^{2} / \mu\right)^{1 / 2} \sin \xi}{G m \mu-\bar{A} \cos \xi},
\end{aligned}
$$

Hasonló módon, mint az előző esetben az $I(\omega, n)$ integrál időfüggését átírjuk $\xi$ excentrikus anomália függésre

$$
I(\omega, n)=\int_{0}^{2 \pi} \frac{\omega}{r^{n+1}}\left(\frac{1}{r} \frac{d t}{d \xi}\right) d \xi
$$


Az általánosított excentrikus anomália paraméterezés (6.2丁) az $n^{\prime} \equiv-n-1 \geq 0$ hatványkitevőre alkalmazva a binomiális tételt

$$
(2 r)^{n^{\prime}}=\sum_{k=0}^{n^{\prime}}\left(\begin{array}{l}
k \\
n^{\prime}
\end{array}\right) r_{\min }^{k} r_{\max }^{n^{\prime}-k}(1+\cos \xi)^{k}(1-\cos \xi)^{n^{\prime}-k}
$$

amely a fordulópontok és $\cos \xi$ polinomiális kifejezése. A (6.20) paraméterezést és az (5.22) radiális egyenletet használva, a (5.24) integrandus zárójelben lévő kifejezésére a következőt kapjuk

$$
\begin{aligned}
\frac{1}{r} \frac{d t}{d \xi} & =\sqrt{\frac{\mu}{-2 E}}\left(1-\frac{E}{2 \mu \bar{A}^{2} \sin ^{2} \xi} \Upsilon\right) \\
\Upsilon & =\sum_{i=0}^{p}\left(\Omega_{+}^{i}-\Omega_{-}^{i} \cos \xi-\frac{2 \varphi_{i}(\xi)}{r^{i-2}}\right) \\
\Omega_{ \pm}^{i} & =\left(\frac{\mu}{\bar{L}^{2}}\right)^{i-2}\left[\varphi_{i}^{+}(G m \mu-\bar{A})^{i-2} \pm \varphi_{i}^{-}(G m \mu+\bar{A})^{i-2}\right]
\end{aligned}
$$

ahol a $\varphi_{i}^{-}$és a $\varphi_{i}^{+}$mennyiségek megegyeznek a fentebb definiált valódi anomáliával megadott koefficiensekkel (6.16) (mivel a peri- és apocentrumban mind a $\chi$ valódi és mind a $\xi$ excentrikus anomália ugyanazon 0 és $\pi$ szögértékeket vesz fel) és a $\varphi_{i}(\xi)$ koefficiensek a (G.22), (6.2: ) összefüggések segítségével adhatók meg a (6.15) $\varphi_{i}(\chi)$-ből

$$
\varphi_{i}(\xi)=\sum_{j=0}^{\infty}\left(f_{i j}+g_{i j} \frac{G m \mu \cos \xi-\bar{A}}{G m \mu-\bar{A} \cos \xi}\right)\left(\frac{-2 E \bar{L}^{2} \sin \xi}{G m \mu^{2}-\bar{A} \mu \cos \xi}\right)^{j} .
$$

A (6.201) feltételt megkövetelve az együtthatókra, belátható, hogy a $\sin ^{2} \xi$-vel arányos tag kiemelhető az $\Upsilon$ kifejezésből és így a ([6.26]) egyenlet továbbra is megörzi a regularitását.

A legfőbb különbség a valódi anomália paraméterezéssel szemben, hogy a (6.27) kifejezésben lévő $\varphi_{i}(\xi) / r^{i-2} \operatorname{tag}(G m \mu-\bar{A} \cos \xi)$ mennyiséggel arányos tagokat adhat a (6.24) integrandus nevezőjében. Ezért ebben az esetben egy második pólus is megjelenhet az origón kívül, amely a [33] irodalom szerint a következő

$$
w_{1}=\left(\frac{G m \mu^{2}-\sqrt{-2 \mu E \bar{L}^{2}}}{G m \mu^{2}+\sqrt{-2 \mu E \bar{L}^{2}}}\right)^{1 / 2} .
$$

A fenti eredmények, a következő tétel kimondásához vezettek:

Tétel 2.: A teljes perturbált Kepler-mozgást a radiális egyenlet (5.22) jellemzi, ahol a $\varphi_{i}(\xi)$ periódikus perturbációk, melyek a (6.T5) alakú Fouriersorba írhatók. Ha a $\varphi_{i}(\chi)$-ban lévő koefficiensekre teljesül a(6.20) feltétel, 
akkor egy tetszőleges $\omega$ periódikus függvényre az $I(\omega, n<0)$ integrál értéke megegyezik a $w=\exp (i \xi)$ változócserével kapott komplex számsík origójában és a (6.30) $w_{1}$-ben vett reziduumainak összegével (minden $\varphi_{i}$-ben lévő $f_{i j}$-re $i+j>2$, illetve $g_{i j}$-re $i+j>1$ ).

$\mathrm{Az}$ előzőekben megállapított tételek tartalmazzák a [33] irodalomban bemutatott eseteket, melyek a $\varphi_{i}$ állandó együtthatójú perturbációs koefficiensekre teljesülnek, emiatt a regularitást biztosító feltétel (6.20) automatikusan teljesül.

\subsection{Alkalmazás kettős rendszerekre}

Ebben a fejezetben néhány példán keresztül bemutatom a perturbációkat, melyek az általános Brumberg erőt (mely tartalmazza az általános perturbáló erő összes komponensét)a SO, SS, QM és DD előzőekben tárgyalt járulékokat, hogy a $\varphi_{i}(\chi)$ függvények milyen alakúak. A példákban látható lesz, hogy a $\varphi_{i}(\chi) \mathrm{SS}, \mathrm{QM}$ és DD esetek perturbációs esetek hasonlók, ugyanis a $\varphi_{i}(\chi)$ perturbációs függvények hasonló struktúrát mutatnak.

\subsection{1. Általános Brumberg erő}

Az általános Brumberg-erő [3]], [32] tartalmazza a klasszikus égi mechanikai perturbációkat, melyet a Lagrange-formalizmusból származtathatunk. A Brumberg-erőre vonatkozó Lagrange-függvény a következő

$$
\begin{aligned}
\mathcal{L}_{B}= & \frac{\mu \mathbf{v}^{2}}{2}+\frac{G m \mu}{r}+\mathcal{L}_{P B} \\
\mathcal{L}_{P B}= & \frac{1}{4 c^{2}}\left(\alpha-\beta+\frac{\lambda}{2}\right) \mu \mathbf{v}^{4}+\alpha \frac{G m \mu}{c^{2} r^{3}}(\mathbf{r v})^{2} \\
& +\left(\beta-\alpha+\frac{\lambda}{2}\right) \frac{G m \mu}{c^{2} r} \mathbf{v}^{2}+\left(\beta-\gamma+\frac{\lambda}{2}\right) \frac{G^{2} m^{2} \mu}{c^{2} r^{2}}
\end{aligned}
$$

ahol $\alpha, \beta, \gamma$ és $\lambda$ perturbációs paraméterek. A (6.32)-böl megkapható a Brumberg-féle radiális egyenlet [3:3], melyből a bevezetett ([-]) segítségével felírhatók a $\varphi_{i}^{B}$ perturbációs koefficiensek

$$
\begin{aligned}
\varphi_{0}^{B} & =-\frac{3 E^{2}}{c^{2}}(2 \alpha-2 \beta+\lambda), \\
\varphi_{1}^{B} & =-4 \frac{G m \mu E}{c^{2}}(3 \alpha-2 \beta+2 \lambda), \\
\varphi_{2}^{B} & =-2 \frac{G^{2} m^{2} \mu^{2}}{c^{2}}(3 \alpha-2 \beta+2 \lambda+\gamma)+\frac{2 E L^{2}}{\mu c^{2}}(2 \alpha-2 \beta+\lambda), \\
\varphi_{3}^{B} & =2 \frac{G m L^{2}}{c^{2}}(\alpha+2 \lambda) .
\end{aligned}
$$


$\mathrm{Az}$ összes $\varphi_{i}^{B}$ koefficiens állandó, így ezen perturbációk kezelésére a [33] irodalomban található tételek alkalmazhatók. Az általános Brumberg-erővel lehet definiálni a PN korrekciót a következőképpen: $\alpha=\eta / 2, \beta=(1+3 \eta) / 2, \gamma=2+\eta, \lambda=2-\eta$.

\subsubsection{Fizikai esetek}

A fizikailag érdekes esetek a SO, SS, QM és DD kölcsönhatások. A SO kölcsönhatás radiális egyenletéből leolvasható a $\varphi_{i}^{S O}$ perturbációs koefficiensek, melyek a különböző SSC-mértékekben az alábbiak

$$
\begin{aligned}
{ }^{I} \varphi_{2}^{S O} & =\frac{2 E}{c^{2} m}(\mathbf{L} \cdot \boldsymbol{\sigma}) \\
{ }^{I} \varphi_{3}^{S O} & =-\frac{2 G \mu}{c^{2}}(2 \mathbf{L} \cdot \mathbf{S}+\mathbf{L} \cdot \boldsymbol{\sigma}) \\
{ }^{I I} \varphi_{3}^{S O} & =-\frac{G \mu}{c^{2}}(4 \mathbf{L} \cdot \mathbf{S}+3 \mathbf{L} \cdot \boldsymbol{\sigma}) \\
{ }^{I I I} \varphi_{2}^{S O} & =-\frac{2 E}{c^{2} m}(\mathbf{L} \cdot \boldsymbol{\sigma}) \\
{ }^{I I I} \varphi_{3}^{S O} & =-\frac{2 G \mu}{c^{2}}(2 \mathbf{L} \cdot \mathbf{S}+2 \mathbf{L} \cdot \boldsymbol{\sigma})
\end{aligned}
$$

Az összes ${ }^{I, I I, I I I} \varphi_{i}^{S O}$ koefficiens vezetőrendben állandó, ugyanis a $\cos \kappa_{i}$ (Z). ábra) változásának rendje $1 \mathrm{PN}$ [92], így tekinthető ebben a rendben állandónak.

A SS, QM és DD járulékok dinamikailag eltérnek az előzőekben bemutatott esetektől, mivel itt csak az $E$ energia a mozgásállandó, viszont az $L$ pálya-impulzusmomentum nagysága nem, mivel a Lagrange-függvényekből megmutatható, hogy az $\dot{\mathbf{L}} \neq 0$ 函. A SS, QM és DD perturbációkra felírható az $\dot{\mathbf{L}}$ ismeretében a pálya-impulzusmomentum nagyságának változása a valódi anomáliával, vagyis $L=L(\chi)$. Ezért célszerüvé vált a „A radiális mozgás" címü fejezetben már ismertetésre került $\bar{L}$ átlagolt pályaimpulzusmomentum nagyságot bevezetni, mely az átlagolás miatt már mozgásállandó

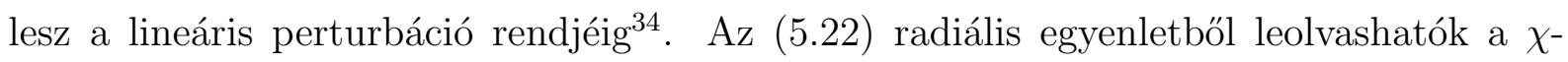

\footnotetext{
${ }^{33} \mathrm{Az}$ SO kölcsönhatásnál szintén $\dot{\mathbf{L}} \neq 0$, ellenben az $L$ pálya-impulzusmomentum nagysága állandó [92]

${ }^{34} \mathrm{Az} \mathrm{SS}, \mathrm{QM}$ és DD járulékok $E$ és $\bar{L}$ megmaradó mennyiségekkel való leírása a ( [38] , [8.3] és [9.3] ) irodalmakban található.
} 
függő koefficiensek, melyek a következők lesznek

$$
\begin{aligned}
\varphi_{2}^{S S} & \left.=\frac{G \mu^{2}}{2 c^{2} \bar{L}^{3}} S_{1} S_{2} \sin \kappa_{1} \sin \kappa_{2}\{2 \bar{A} \cos (\chi+\delta)]+(3 G m \mu+2 \bar{A} \cos \chi) \cos (2 \chi+\delta)\right\} \\
\varphi_{3}^{S S} & =\frac{G \mu}{c^{2}} S_{1} S_{2}\left[3 \cos \kappa_{1} \cos \kappa_{2}-\cos \gamma-3 \sin \kappa_{1} \sin \kappa_{2} \cos (2 \chi+\delta)\right], \\
\varphi_{2}^{Q M} & =-\frac{G m^{3} \mu^{3}}{2 \bar{L}^{2}} \sum_{i=1}^{2} p_{i} \sin ^{2} \kappa_{i}\left\{2 \bar{A} \cos \left(\chi+\delta_{i}\right)+(3 G \mu m+2 \bar{A} \cos \chi) \cos \left(2 \chi+\delta_{i}\right)\right\} \\
\varphi_{3}^{Q M} & =-G \mu^{2} m^{3} \sum_{i=1}^{2} p_{i}\left[1-3 \sin ^{2} \kappa_{i} \cos ^{2}\left(\chi+\frac{\delta_{i}}{2}\right)\right] \\
\varphi_{2}^{D D} & =-\frac{\mu^{2} d_{1} d_{2}}{\bar{L}^{2}}\left[(3 G m \mu+4 \bar{A} \cos \chi) \mathcal{B}_{2}(\chi)-\bar{A} \sin \chi \mathcal{B}_{2}^{\prime}(\chi)\right], \\
\varphi_{3}^{D D} & =-\mu d_{1} d_{2}\left[\mathcal{A}_{0}-3 \mathcal{B}_{2}(\chi)\right],
\end{aligned}
$$

ahol az $\mathcal{A}_{0}=\alpha_{D D}$ és $\mathcal{B}_{2}(\chi)=\beta_{D D}(2 \chi)$ melyek a $\mathrm{B}$ függelékben a $(\mathbb{B}-66)$ és $(\mathbb{B}-7 \mathbb{1})$ egyenletekkel vannak definiálva, illetve a $\mathcal{B}_{2}^{\prime}(\chi)=d \mathcal{B}_{2}(\chi) / d \chi$. Látható, hogy $\varphi_{i}(\chi)$ perturbációk nem állandók, így a korábban megállapított tételek alkalmazhatóak ezen perturbációkra.

Megvizsgálható, hogy a (6.3.) -ben szereplő mennyiségek az $f_{i 1}$ és $g_{i 1}$ koefficiensek a (6.15) segítségével milyen formában adhatók meg. A számolásaim azt mutatták, hogy a (6.201) regularitási feltétel alapján a koefficiensek az $f_{21}=\bar{A} \Sigma, f_{31}=0, g_{21}=G m \mu \Sigma$ és $g_{31}=-\left(\bar{L}^{2} / \mu\right) \Sigma$ struktúrát követték, ahol $\Sigma$ tartalmazza a SS, DD és QM járulékokra jellemző ,,specifikációkat”, melyek az alábbiak

$$
\begin{aligned}
\Sigma & =\Sigma_{S S}+\Sigma_{Q M}+\Sigma_{D D} \\
\Sigma_{Q M} & =-\frac{6 G \mu^{3} m^{3}}{2 \bar{L}^{2}} \sum_{j} p_{j} \sin ^{2} \kappa_{j} \sin 2 \delta_{j} \\
\Sigma_{S S} & =-\frac{6 G \mu^{2} S_{1} S_{2}}{c^{2} \bar{L}^{2}} \sin \kappa_{1} \sin \kappa_{2} \sin \delta \\
\Sigma_{D D} & =\frac{6 G \mu^{2} d_{1} d_{2}}{\bar{L}^{2}}\left[\left(\sigma_{1} \sigma_{2}-\rho_{1} \rho_{2}\right) \sin \left(\delta_{1}+\delta_{2}\right)+\left(\rho_{1} \sigma_{2}+\rho_{2} \sigma_{1}\right) \cos \left(\delta_{1}+\delta_{2}\right)\right]
\end{aligned}
$$

Ezzel belátható, hogy a SS, QM és DD fizikailag érdekes kölcsönhatások hasonló jellegü perturbációk, melyekre a fentebb kidolgozott módszer jól alkalmazható, vagyis a tételekkel a szekuláris integrálok könnyen kiszámolhatók a reziduum-tétel segítségével [37]. 


\section{Kettösök szögmozgása}

A szögmozgás alatt a radiális egyenleten kívül a Lagrange-függvényből kapható gömbi polárszögekre vonatkozó fejlődési egyenleteket értem melyek a szemléletesebb jelentés miatt Euler-szögekkel is felírhatók.

Ismert, hogy a tisztán relativisztikus PN-korrekciókban az $\mathbf{L}$ pálya-impuzusmomentum megmaradó mennyiség, így a pályasík helyzete nem változik a mozgás folyamán, tehát a Lagrange-függvényből két szögegyenlet származtatható, melyek a pályasíkon való mozgást adják meg. Így a szögfejlődés két részből tevődik össze, nevezetesen a perihéliumtól való „,kepleri” mozgásból, illetve a perihélium mozgásából (,,perihélium vándorlás”) [17].

Amennyiben figyelembe vesszük a testek véges méretéből adódó effektusokat (forgás, tömeg kvadrupólmomentum, mágneses dipólmomentum) a szögmozgás meglehetősen bonyolult lesz, mivel a pályasík nem megmaradó mennyiség.

A spinek leírását számos szerző a Hamilton-formalizmusból származtatta [9]], [95], melyeknél a spinek okozta pályasík változást nem vették figyelembe a szögmozgásban.

A testek forgása esetén a $\mathbf{J}=\mathbf{L}+\mathbf{S}_{\mathbf{1}}+\mathbf{S}_{\mathbf{2}}$ teljes impulzusmomentum lesz a megmaradó mennyiség (mivel $\dot{\mathbf{L}} \neq \mathbf{0}$ a spinprecessziós egyenletek [68, [6. $]$ ), ezért a hozzá rögzített invariáns rendszerben a szögmozgás tanulmányozható. A pályasíkot az $\mathbf{L}_{\mathbf{N}}=\mathbf{r} \times \mathbf{v}$ definiálja, (amely nem azonos a J-re merőleges síkkal) melyet az invariáns rendszerben fogok felírni, majd az $\mathbf{L}_{\mathbf{N}}$ komponensei segítségével megadom a polár és az Euler-szögekre vonatkozó fejlődési egyenleteket.

A továbbiakban a vezetőrendü szögmozgás egyenleteit származtatom, melyek tulajdonképpen az SO és PN kölcsönhatásból adódó járulékok [96]. Használni fogom a $\mathbf{J}$ teljes impulzusmomentumot, a spinek közti relatív $\gamma$ szöget, az $\mathbf{L}_{\mathbf{N}}$ és az egyes spinek közti $\kappa_{i}$ szögeket és a pályasíkon a spinek azimutális $\psi_{i}$ szögeit, melyek az l̂ csomóvonaltól mérhetőek ([).

A pályát jellemző bevezetett Euler-szögek az $\alpha$ a pályasík pályahajlása vagy pályainklináció, amely a $\mathbf{J}$ és $\mathbf{L}_{\mathbf{N}}$ közti szög, a $\phi_{n}$ az $\hat{\mathbf{l}}$ csomóvonal és az inerciális $\hat{\mathbf{x}}^{-}$ tengely közti szög, valamint a $\psi_{p}$ a periasztron és az $\hat{\mathbf{l}}$ csomóvonal közti szög (प).

\subsection{Pálya-impulzusmomentum származtatása}

A vezetőrendü szögegyenletek megadásához megvizsgáltam a Lagrange-függvényben (5.4) szereplő járulékokat, amelyből kiderült, hogy a newtoni tagon kívül csak a PN és a SO járulékok változnak a legalacsonyabb rendben. A SO kölcsönhatást a fentebb is használt SSC II mértékben írom fel az egyszerüség kedvéért, mivel a származtatott kifejezések a $(4 \mathbf{S}+3 \boldsymbol{\sigma})$ mennyiséggel lesznek arányosak (pl. $\mathbf{L}_{\mathbf{S O}}$ és $\left.\dot{\mathbf{L}}_{\mathbf{N}}\right)$. 
Az $L$ pálya-impulzusmomentum nagysága megmaradó mennyiség, így itt sem szükséges az $\bar{L}$ átlag jelölés, amely a SS, QM és DD járulékoknál indokolt volt.

$\mathrm{Az}$ L-et a (5.4) Lagrange-függvényből az $\mathbf{L}=\mathbf{r} \times(\partial \mathcal{L} / \partial \mathbf{v})$ egyenlet alapján származtatva a következő kapható

$$
\mathbf{L}=\mathbf{L}_{\mathbf{N}}+\mathbf{L}_{\mathbf{P N}}+\mathbf{L}_{\mathbf{S O}}
$$

ahol

$$
\begin{aligned}
\mathbf{L}_{\mathbf{N}} & =\mu \mathbf{r} \times \mathbf{v} \\
\mathbf{L}_{\mathbf{P N}} & =\mathbf{L}_{\mathbf{N}}\left[\frac{(1-3 \eta)}{2} \frac{\mathbf{v}^{2}}{c^{2}}+(3+\eta) \frac{G m}{c^{2} r}\right], \\
\mathbf{L}_{\mathbf{S O}} & =\frac{G \mu}{2 c^{2} r^{3}} \mathbf{r} \times[\mathbf{r} \times(4 \mathbf{S}+3 \boldsymbol{\sigma})]
\end{aligned}
$$

A (ㅁ.D) négyzetére a következő egyszerü jelöléseket vezetem be PN és SO járulékokra

$$
L^{2}=L_{N}^{2}+\lambda_{P N}+\lambda_{S O}
$$

ahol

$$
\begin{aligned}
& \lambda_{P N} \equiv 2 \mathbf{L}_{\mathbf{N}} \cdot \mathbf{L}_{\mathbf{P N}}=2 L^{2}\left[(1-3 \eta) \frac{E}{c^{2}}+2(2-\eta) \frac{G m \mu}{c^{2} r}\right], \\
& \lambda_{S O} \equiv 2 \mathbf{L}_{\mathbf{N}} \cdot \mathbf{L}_{\mathbf{S O}}=-\frac{G \mu L}{c^{2} r} \sum_{i=1, j \neq i}^{2} \frac{4 m_{i}+3 m_{j}}{m_{i}} S_{i} \cos \kappa_{i} .
\end{aligned}
$$

A $\lambda_{P N}$ és $\lambda_{S O}$ használatával jól elkülöníthetők az SO és PN járulékok. A továbbiakban a vezetörendü (PN és SO) esetekre írom fel az Euler-szögekre vonatkozó fejlődési egyenleteket.

\subsection{Euler-szögek}

A megmaradó J teljes impulzusmomentumhoz rögzítem a koordinátarendszert, vagyis a $z$-tengely a $\mathbf{J}$ irányba és az $x$-tengely a pericentrum irányába mutat (a 3 . tengely értelemszerüen jobbsodrású rendszernek megefelelően választható meg) (प1. ábra). Ebben az inerciális rendszerben a $\theta, \varphi$ gömbi polárszögek segítségével megadható az $\mathbf{L}_{\mathbf{N}}$ pályaimpulzusmomentum vektor, amely a következő lesz

$$
\mathbf{L}_{\mathbf{N}}=\mu r^{2}\left(\begin{array}{c}
-\dot{\theta} \sin \varphi-\dot{\varphi} \sin \theta \cos \theta \cos \varphi \\
\dot{\theta} \cos \varphi-\dot{\varphi} \sin \theta \cos \theta \sin \varphi \\
\dot{\varphi} \sin ^{2} \theta
\end{array}\right)
$$


$\mathrm{Az} \mathbf{L}_{\mathbf{N}}$-hez rögzített nem-inerciális rendszert az Euler-szögekkel $\left(\phi_{n}, \alpha, \psi\right)$ jellemezhetjük a J-hez képest, mely a gömbi polárszögekkel a következőképpen definiálhatók

$$
\begin{aligned}
\sin \theta \cos \varphi & =\cos \alpha \sin \phi_{n} \sin \psi+\cos \phi_{n} \cos \psi, \\
\sin \theta \sin \varphi & =\cos \alpha \cos \phi_{n} \sin \psi-\sin \phi_{n} \cos \psi, \\
\cos \theta & =\sin \alpha \sin \psi .
\end{aligned}
$$

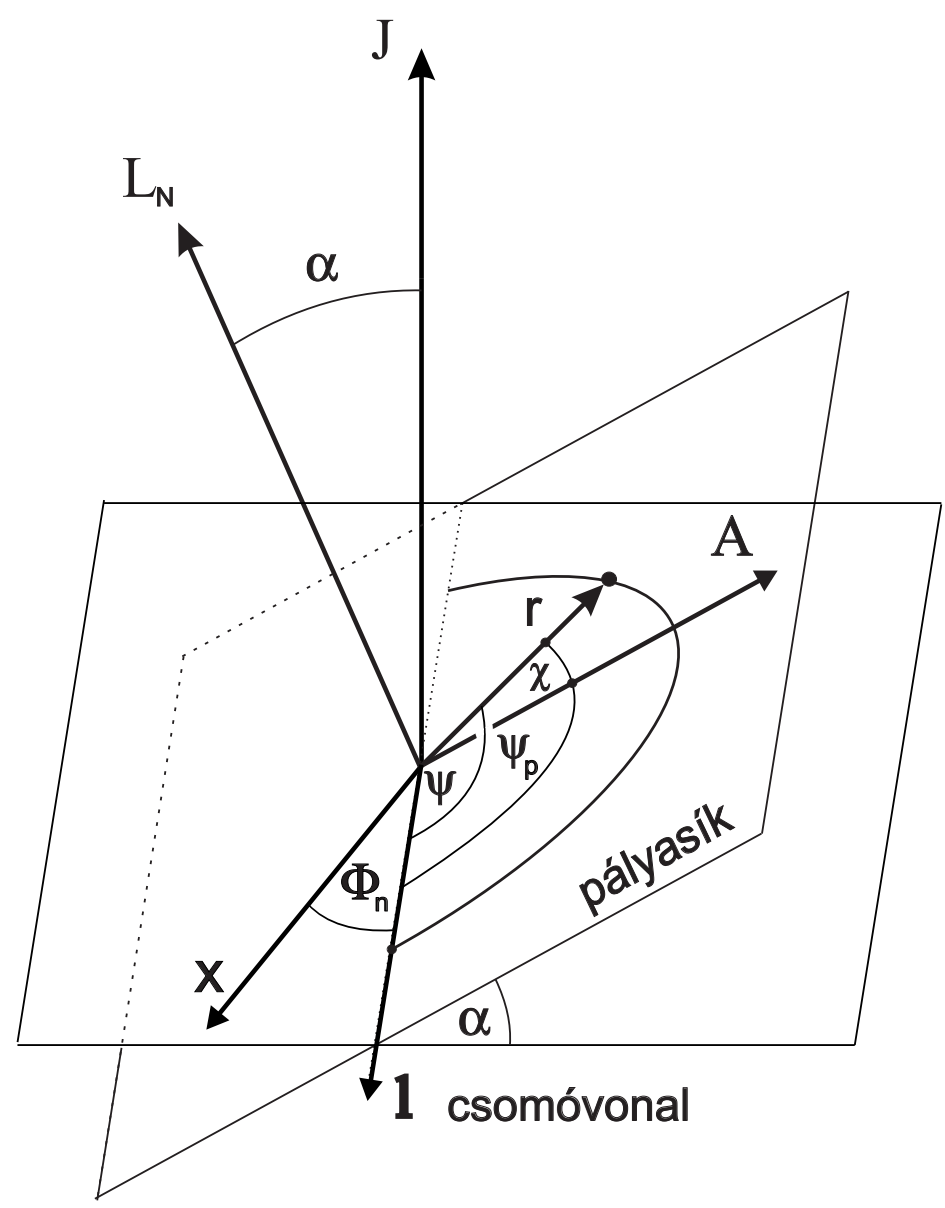

9. ábra. Euler-szögek.

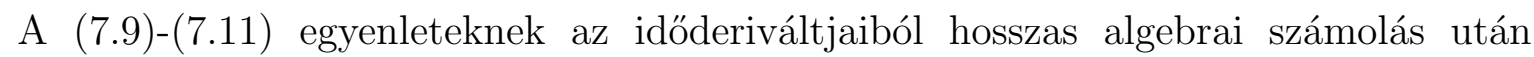
megkaphatók a polár és az Euler-szögek közti általános (közelítés nélküli) időfejlődési egyenletek

$$
\begin{aligned}
\dot{\psi} & =\cos \alpha \dot{\varphi}-\frac{\sin \alpha \cos \psi}{\sin \theta} \dot{\theta}+\cos \alpha \dot{\phi}_{n} \\
\dot{\phi}_{n} & =-\dot{\varphi}-\frac{\cot \alpha}{\sin \theta \cos \psi} \dot{\theta}+\frac{\tan \psi}{\sin ^{2} \alpha}(\cos \alpha)
\end{aligned}
$$

Ezek után a $\theta$ és $\varphi$ polárszögekkel megadható az $\mathbf{L}_{\mathbf{N}}$ pálya-impulzusmomentum vektor 
nagysága és 3. komponense, melyek a (ㅁ.8) alapján a következők

$$
\begin{aligned}
L_{N}^{2} & =\mu^{2} r^{4}\left(\dot{\theta}^{2}+\sin ^{2} \theta \dot{\varphi}^{2}\right) \\
\left(\mathbf{L}_{\mathbf{N}}\right)_{z} & =\mu r^{2} \sin ^{2} \theta \dot{\varphi} .
\end{aligned}
$$

A (ㅍ.5) $L$ nagyságát, a (‥T]) és a $\left(\mathbf{L}_{\mathbf{N}}\right)_{z}=L_{N} \cos \alpha$ egyenleteket (amellyel bevezettem az $\alpha$ pályainklináció szögét) alkalmazva a (‥4) és a ([.T. egyenletekre az alábbiak írhatók fel

$$
\begin{aligned}
\sin \theta \dot{\theta} & =-\frac{L}{\mu r^{2}} \sin \alpha \cos \psi\left(1-\frac{\lambda_{P N}+\lambda_{S O}}{2 L^{2}}\right) \\
\sin ^{2} \theta \dot{\varphi} & =\frac{L}{\mu r^{2}} \cos \alpha\left(1-\frac{\lambda_{P N}+\lambda_{S O}}{2 L^{2}}\right) .
\end{aligned}
$$

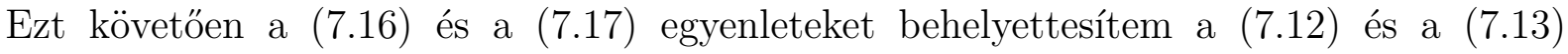
egyenletekbe, így megadhatók a végleges alakú fejlődési egyenletek, melyekben már csak az Euler-szögek szerepelnek ${ }^{[3 .]}$

$$
\begin{aligned}
\dot{\psi} & =\frac{L}{\mu r^{2}}\left(1-\frac{\lambda_{P N}+\lambda_{S O}}{2 L^{2}}\right)+\dot{\phi}_{n} \cos \alpha, \\
\dot{\phi}_{n} & =\frac{\tan \psi}{\sin ^{2} \alpha}(\cos \alpha)
\end{aligned}
$$

melyek kepleri esetben a $\dot{\psi}_{N}=L / \mu r^{2}$ és a $\phi_{n}=$ állandó egyenletekre egyszerüsödnek.

Ezen két szögegyenlet nem zárt, mivel tartalmazza az $\alpha$ Euler-szöget, ezért szükség van $\dot{\alpha}$ megadására.

\subsection{Pályainklináció}

Az előző ([Z.9-[T.T]) egyenletekből következik, hogy a 3. Euler szög (pályainklináció) a $\cos \alpha=\hat{\mathbf{J}} \cdot \hat{\mathbf{L}}_{\mathbf{N}}$ összefüggésből adható meg. A $\cos \alpha$ időfüggése egyszerűen származtatható a $(\cos \alpha)^{\cdot}=\hat{\mathbf{J}} \cdot\left(\hat{\mathbf{L}}_{\mathbf{N}}\right)^{\cdot}$ kifejezésből, mivel $\mathbf{J}$ megmaradó mennyiség. Ehhez szükség van az $\dot{\mathbf{L}}_{\mathbf{N}}$ kiszámolásához, amely a PN és SO járulékra vonatkozó gyorsulásból (5.6) kapható meg, vagyis az $\mathbf{L}_{\mathbf{N}}$ newtoni pálya-impulzusmomentum vektor időfejlődése a következő

$$
\begin{aligned}
\dot{\mathbf{L}}_{\mathbf{N}}= & \mu \mathbf{r} \times \mathbf{a}=\frac{2 G m}{c^{2} r^{2}}(2-\eta) \dot{r} \mathbf{L}_{\mathbf{N}} \\
& +\frac{G \mu}{c^{2} r^{3}}\left\{\left(\frac{3}{2} \frac{\dot{r}}{r} \mathbf{r}-\mathbf{v}\right)[\mathbf{r} \cdot(4 \mathbf{S}+3 \boldsymbol{\sigma})]-\frac{r \dot{r}}{2}(4 \mathbf{S}+3 \boldsymbol{\sigma})\right\},
\end{aligned}
$$

\footnotetext{
${ }^{35}$ A ([.T6) egyenletet a ([.T4) gyökvonásából kaptam, ezért a " -" előjelet úgy választottam meg, hogy

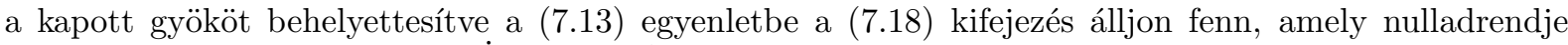
vissza kell, hogy adja a kepleri $\dot{\psi}_{N}=L / \mu r^{2}$ kifejezést.
} 
ahol az első tag a PN, a többi a SO járulékból adódik. Az $\hat{\mathbf{L}}_{\mathbf{N}}$ egységvektor deriváltját előállítva a (담) egyenletből megkapjuk a vezetőrendü pályainklinációra vonatkozó szögfejlődési egyenletet $\left(L_{N} \simeq L\right)$

$$
\begin{aligned}
(\cos \alpha)^{\cdot}= & \frac{G \mu \dot{r}}{2 c^{2} J L r^{2}}\left[(4+3 \nu) S_{1} \cos \kappa_{1}+\left(4+3 \nu^{-1}\right) S_{2} \cos \kappa_{2}\right] \\
& \times\left(S_{1} \cos \kappa_{1}+S_{2} \cos \kappa_{2}\right) \\
& -\frac{G \mu \dot{r}}{2 c^{2} J L r^{2}}\left[(4+3 \nu) S_{1}^{2}+\left(4+3 \nu^{-1}\right) S_{2}^{2}\right. \\
& \left.+\left[8+3\left(\nu+\nu^{-1}\right)\right] S_{1} S_{2} \cos \gamma\right] \\
& +\frac{G \mu}{c^{2} J L r^{3}}\left[(4+3 \nu) \mathbf{r} \cdot \mathbf{S}_{\mathbf{1}}+\left(4+3 \nu^{-1}\right) \mathbf{r} \cdot \mathbf{S}_{\mathbf{2}}\right] \\
& \times\left(\frac{3}{2} \frac{\dot{r}}{r} \mathbf{r}-\mathbf{v}\right) \cdot\left(\mathbf{S}_{\mathbf{1}}+\mathbf{S}_{\mathbf{2}}\right)
\end{aligned}
$$

amelyből a PN járulék kiesik (mivel a pályasík megmaradó mennyiség PN esetén). A (․2U) egyenletben a skalárszorzatok a következőképpen néznek ki a fentebb bevezetett gömbi polárszögekkel (四. ábra)

$$
\begin{aligned}
\mathbf{r} \cdot \mathbf{S}_{\mathbf{i}} & =r S_{i} \sin \kappa_{i} \cos \left(\psi_{p}+\chi-\psi_{i}\right) \\
\mathbf{v} \cdot \mathbf{S}_{\mathbf{i}} & =\dot{r} S_{i} \sin \kappa_{i} \cos \left(\psi_{p}+\chi-\psi_{i}\right)-\frac{L S_{i}}{\mu r} \sin \kappa_{i} \sin \left(\psi_{p}+\chi-\psi_{i}\right) .
\end{aligned}
$$

Látható, hogy az $\alpha$ pályainklináció vezetőrendű fejlődése (ㅍ.2】) a spinekben kvadratikus $\left((\cos \alpha)^{\circ} \propto S^{2} / J L\right)$, amely egyrészt mutatja, hogy a pályasík változása magasabb rendnél jelentkezik, illetve, hogy ezen tagokban elegendő a (3.43) newtoni valódi anomália parametrizáció használata, amely a dinamikai változókkal a következőképpen néz ki

$$
r=\frac{L^{2}}{\mu(G m \mu+A \cos \chi)}, \quad \dot{r}=\frac{A}{L} \sin \chi .
$$

Ezzel megadtam az összes (ㅁ. egyenleteket a $\chi$ valódi anomáliával (a $\chi$ a newtoni rendü $\left(\psi-\psi_{p}\right)$-vel azonos $\mathbf{0}$. ábra). A továbbiakban a szögegyenletek szekuláris fejlődését számolom ki.

\subsection{Euler-szögek szekuláris fejlődése}

A szekuláris fejlődéshez a korábban is használt definíció szükséges ${ }^{[6]}$, mivel a ([R.T. és a ([ா.2]) pillanatnyi szögfejlődési egyenleteknek nincs nulladrendü járuléka, ezért elegendő a

\footnotetext{
${ }^{36}$ A szekuláris időfejlődés definíciója a következő $<\dot{f}>=T^{-1} \int_{0}^{2 \pi} \dot{f}(\chi) \dot{\chi}^{-1} d \chi$, ahol $f(\chi)$ egy tetszőleges függvénye a $\chi$ valódi anomáliának ( $T$ a pálya periódusideje).
} 
kepleri mozgásból adódó $T=2 \pi G m[\mu /(-2 E)]^{3 / 2}$ pálya periódusidőre (amely a Kepler 3 . törvényéből kapható meg a nulladrendű energiából) átlagolni. Így, a következő szekuláris szögegyenletek kaphatóak

$$
\begin{aligned}
\sin \alpha\langle\dot{\alpha}\rangle= & \frac{3 G(-2 E \mu)^{3 / 2}}{2 c^{2} J L^{3}}\left(\nu-\nu^{-1}\right) S_{1} S_{2} \sin \kappa_{1} \sin \kappa_{2} \sin \Delta \psi \\
\sin ^{2} \alpha\left\langle\dot{\phi}_{n}\right\rangle= & \frac{G(-2 E \mu)^{3 / 2}}{2 c^{2} J L^{3}}\left[\sum_{i=1}^{2}\left(4+3 \nu^{3-2 i}\right) S_{i}^{2} \sin \kappa_{i}^{2} \cos 2 \psi_{i}\right. \\
& \left.+S_{1} S_{2}\left[8+3\left(\nu+\nu^{-1}\right)\right] \sin \kappa_{1} \sin \kappa_{2} \cos 2 \bar{\psi}\right] .
\end{aligned}
$$

A $\psi$ szögre vonatkozó ([.]8) fejlődési egyenletnek kepleri járuléka $\left(\dot{\psi}_{N}=L / \mu r^{2}\right)$ van, ezért a radiális periódusra vonatkozó átlagolásban a PN és SO járulékait is figyelembe kell venni. Látható, hogy a $(d t / d \chi)_{N}$ kepleri tagja nem ad járulékot a $\psi$ szög szekuláris fejlődéséhez, mivel $\int_{0}^{2 \pi}\left(L / \mu r^{2}\right)(d t / d \chi)_{N} d \chi=2 \pi$. A ([./8) egyenletet átlagolva a radiális mozgásnál megadott (525) egyenletekben szereplő $(d t / d \chi)_{P N}$ és $(d t / d \chi)_{S O}$ járulékok segítségével, valamint a $\left\langle\dot{\psi}_{p}\right\rangle \equiv(\delta \psi-2 \pi) / T$ egyenletet bevezetve (ahol $\left.\delta \psi=\int_{0}^{2 \pi}(\dot{\psi})(d t / d \chi) d \chi\right)$, felírható a szekuláris fejlődése a periasztron precessziójának, amely az alábbi alakú

$$
\left\langle\dot{\psi}_{p}\right\rangle=\frac{G m(-2 E)^{3 / 2} \mu^{1 / 2}}{c^{2} L^{2}}\left(3-\eta \frac{B_{S}}{L}\right)+\cos \alpha\left\langle\dot{\phi}_{n}\right\rangle,
$$

ahol $B_{S}=(4+3 \nu) S_{1} \cos \kappa_{1}+\left(4+3 \nu^{-1}\right) S_{2} \cos \kappa_{2}$ egy bevezetett mennyiség.

Ezzel megadtam az Euler-szögekre vonatkozó szekuláris fejlődési egyenleteket ([ா:24) és (․25) a konzervatív dinamikában, melyekhez a $\kappa_{i}$ és $\psi_{i}$ szögek szekuláris fejlődéseit ( [92]) csatolva zárt differenciálegyenlet-rendszer kapható. 


\section{Pályafejlődés a gravitációs sugárzás által}

A kettős rendszerek klasszikus mozgásának ismertetése után, ebben a fejezetben az ezen rendszerek által keltett gravitációs sugárzás okozta pályafejlődést mutatom be SO, SS, QM és DD kölcsönhatásokra. Einstein kvadrupól-formulájának (3.3.9) alapján ismert, hogy a mozgó rendszerek által keltett gravitációs hullámok energiát és impulzusmomentumot szállítanak, melyek formálisan az $\mathcal{O}\left(1 / c^{5}\right)$ rendnél jelentkeznek, ezért a mozgó rendszer energiája és impulzusmomentuma az $\mathcal{O}\left(1 / c^{4}\right)$ rendig megmaradó mennyiségek ${ }^{\mathbf{m}}$.

A kettős rendszerek kepleri pályájára számolt vezetőrendü ([.5:3) szekuláris energiaés (3.54) impulzusmomentum-veszteségét Peters és Mathews adták meg először 1963ban [13]. Manapság a veszteségeket magas rendekig számolják a (3.4U) és a (3.42) $E$ és $L_{\alpha}$ mennyiségre vonatkozatott kvadrupól-formula további rendjeinek figyelembevételével, melyek a következőképpen írhatók fel [9.9]

$$
\begin{aligned}
\frac{d E}{d t} & =-\frac{G}{5 c^{5}}\left(\frac{d^{3} I_{\alpha \beta}}{d t^{3}} \frac{d^{3} I_{\alpha \beta}}{d t^{3}}+\frac{16}{9 c^{2}} \frac{d^{3} J_{\alpha \beta}}{d t^{3}} \frac{d^{3} J_{\alpha \beta}}{d t^{3}}+. .\right), \\
\frac{d L_{\gamma}}{d t} & =-\frac{2 G}{5 c^{5}} \varepsilon_{\gamma \alpha \beta}\left(\frac{d^{2} I_{\alpha \delta}}{d t^{2}} \frac{d^{3} I_{\beta \delta}}{d t^{3}}+\frac{16}{9 c^{2}} \frac{d^{2} J_{\alpha \delta}}{d t^{2}} \frac{d^{3} J_{\beta \delta}}{d t^{3}}+. .\right),
\end{aligned}
$$

ahol az $I_{\alpha \beta}=\mu\left[x_{\alpha} x_{\beta}\right]^{S T F}$ tömeg kvadrupólmomentum és a $J_{\alpha \beta}=-\mu\left[x_{\alpha}(\mathbf{r} \times \mathbf{v})_{\beta}\right]^{S T F}$ az árammomentum, amely a vezetőrendü SO járulék esetén az alábbi

$$
J_{S O}^{\alpha \beta}=\frac{3 \mu}{2}\left[x^{\alpha}\left(\frac{\mathbf{S}_{\mathbf{1}}}{m_{1}}-\frac{\mathbf{S}_{\mathbf{2}}}{m_{2}}\right)^{\beta}\right]^{S T F}
$$

ahol az „STF” jelölés a szimmetrikus spúrmentes tenzorokra utal [36] (magasabb rendekben fellépnek még $I_{\alpha \beta \gamma}, J_{\alpha \beta \gamma} \ldots$ mennyiségek [9, ]). A szekuláris energia- és impulzusmomentum-veszteségek elliptikus pályák esetén 3.5 PN rendig ismertek [97].

\subsection{Energiaveszteség}

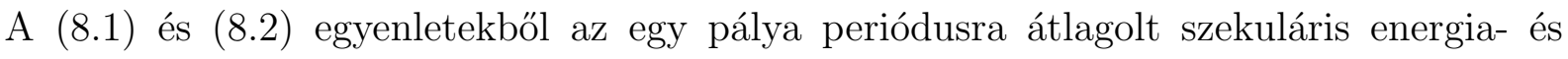
impulzusmomentum-veszteségeket $(\langle d E / d t\rangle$ és $\langle d L / d t\rangle)$ származtatták SO [94], [92], SS [38], QM [8:3] és DD [9:3] esetekben.

A SO kölcsönhatás $\langle d E / d t\rangle$ és $\langle d L / d t\rangle$ szekuláris veszteségei a korábban bevezetett relatív $\kappa_{i}$ szögektől függnek [92] ([7. ábra), amely a $\kappa_{i}$-re vonatkozó sugárzásból adódó

\footnotetext{
${ }^{37} \mathrm{~A}$ spinek jelenlétében a pálya-impulzusmomentum már nem lesz megmaradó mennyiség a spinprecesszió miatt az $\mathcal{O}\left(1 / c^{4}\right)$ rendben (valamint $\mathcal{O}\left(1 / c^{3}\right)$ rendben csak az $L$ nagyság a megmaradó), ezért a $\mathbf{J}$ teljes impulzusmomentum vektort kell használni, amely megmaradó mennyiség $\mathcal{O}\left(1 / c^{4}\right)$-ig. A spinek nagyságának sugárzás miatti változása elhanyagolható [4.9].
} 
fejlődési egyenletekkel zárt differenciálegyenlet-rendszert alkotnak [92].

Az SS, QM és DD kölcsönhatások szekuláris veszteségei az $E$ és $\bar{L}$ mennyiségekkel vannak megadva, mivel ,A radiális mozgás” fejezetben is tárgyalt pályaimpulzusmomentum nem megmaradó mennyiség $(L(\chi))$. A SS kölcsönhatás szekuláris veszteségei a SO esettől eltérően a $\kappa_{i}$ szögeken kívül a korábban bevezetett két spinvektor által bezárt $\gamma$ szöget is tartalmazza [38], [98]. A SS veszteségek a spinek közti ,kölcsönhatási tagokon” (amely $S_{1} S_{2}$-vel arányos) kívül tartalmaznak egy ún. önspin (SS-self) kölcsönhatási tagot, amely az egyes spinek $S_{i}^{2}$-tel arányosak. Ezen tagok úgy keletkeznek, hogy a (8.]) és (8.2) kvadrupól-formula magasabb rendű tagjaiban lévő $J_{S O}^{(3) \alpha \beta} J_{S O}^{(3) \alpha \beta}$ és $\varepsilon^{\alpha \beta \gamma} J_{S O}^{(2) \alpha \delta} J_{S O}^{(3) \beta \delta}$ szorzatokból $S_{i}^{2}$-tel arányos tagok adódnak [38]. Az önspin járulék szintén csak $\kappa_{i}, \gamma$ szögeket tartalmaz, vagyis a differenciálegyenlet-rendszer továbbra is zárt marad $\left(\left\langle d\left(E, \bar{L}, \kappa_{i}, \gamma\right) / d t\right\rangle\right)$. A QM veszteségeiben csak $\kappa_{i}$ szögek jelennek meg, a DD veszteségeiben, viszont a dipólmomentumok leírásához szükséges $\alpha_{i}$ és $\beta_{i}$ szögek is szükségesek (《. ábra), melyek miatt az előző differenciálegyenlet megoldhatóságához hozzá kell venni ezen szögek sugárzásból adódó fejlődési egyenleteit is [93:].

A gravitációs sugárzás miatt a pályák cirkularizálódnak [14], ezért a kvázikörpálya határátmenetet használom az egyszerü számolások végett, így igaz lesz, hogy a gravitációs hullám $f$ frekvenciája kétszerese a $\nu$ pályafrekvenciának $(\omega=2 \pi \nu$, ahol $\omega$ a pálya körfrekvenciája, melyet egyszerüen ,,pályafrekvenciának” nevezem) [9.9], tehát $\omega=\pi f$. A pályafrekvencia-változás a szekuláris energiaveszteségből származtatható

$$
\left(\frac{d \omega}{d t}\right)^{c i r c}=\left(\frac{d E}{d \omega}\right)^{-1}\left\langle\frac{d E}{d t}\right\rangle^{c i r c}
$$

ahol $d E / d \omega$ mennyiségben az $E=E(\omega)$ energiát az $\omega$ pályafrekvenciával fejezem ki. Megmutattam, hogy a $(d E / d t)(r, v, \dot{r})$ pillanatnyi energiaveszteség kvázikörpálya határátmenete megegyezik a $\langle d E / d t\rangle(E, \bar{L})$ szekuláris energiaveszteség körpálya határátmenetéből kapott eredménnyel. Az utóbbi azt jelenti, hogy a megmaradó $E$ és $\bar{L}$ mennyiségeknek vesszük a [2]] irodalomban használt körpálya sugárral kifejezett alakját (pl. nulladrendben $E=-G m \mu / 2 r$ és $L^{2}=G m \mu^{2} r$ ), majd az $r=r(\omega)$ egyenletet használjuk, amely az $\mathbf{r} \cdot \mathbf{a}=-r \omega^{2}$ kvázikörpálya definícióból (5.58) kapható.

A szekuláris energiaveszteségek a különböző járulékok szerint a következők

$$
\left\langle\frac{d E}{d t}\right\rangle=\left\langle\frac{d E}{d t}\right\rangle_{N}+\left\langle\frac{d E}{d t}\right\rangle_{P N}+\left\langle\frac{d E}{d t}\right\rangle_{S O+\text { tail }}+\left\langle\frac{d E}{d t}\right\rangle_{2 P N+(S S-s e l f)+S S+Q M+D D},
$$

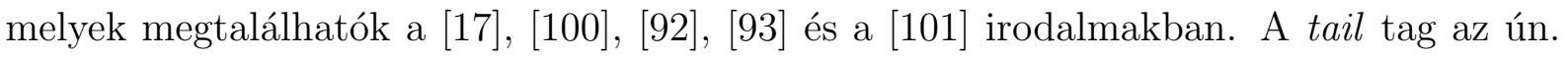
uszály tag, amely a gravitációs hullám véges méretéből adódó 1.5 PN rendű relativisztikus 
korrekció (ezen kívül fellépnek még 2.5 PN, 3 PN és 3.5 PN rendü uszálytagok is).

A következő részben a (区.4) pályafrekvenciára vonatkozó differenciálegyenletet adom meg, majd idő szerint kétszer integrálva kiszámolom a gravitációs hullámok frekvenciáját és fázisát és egy numerikus példán keresztül bemutatom a kettős $\mathcal{N}$ keringések számát a legbelső stabil körpályáig a különböző járulékokra. Megmutatom, hogy a gravitációs hullám fázisában és frekvenciájában az önspin tag jelentős változást okozhat bizonyos spingeometriában, melyet a jelenlegi gravitációs hullámalakokban nem vesznek figyelembe. A számolásaimban a $G=c=1$ geometriai egységet használom.

\subsection{Pályafrekvencia-fejlödés}

A korábban bevezetett kvázikörpálya definíciót (5.58)-(5.50) használom, amelyből a (5.6) gyorsulások radiális projekciója $\left(\mathbf{r} \cdot \mathbf{a}=-r \omega^{2}\right)$ alapján meghatározható a pályafrekvencia $(\omega=\omega(r))$. Ennek invertálásából kiszámolható a körpálya $r=r(\omega)$ sugara, amely a következö

$$
\begin{aligned}
r(\omega)= & m(m \omega)^{-2 / 3}\left\{1-\frac{3-\eta}{3}(m \omega)^{2 / 3}-\frac{m \omega}{3} \sum_{i=1}^{2}\left(2 \frac{m_{i}^{2}}{m^{2}}+3 \eta\right) \frac{S_{i}}{m_{i}^{2}} \cos \kappa_{i}\right. \\
& -(m \omega)^{4 / 3}\left[-\eta\left(\frac{19}{4}+\frac{\eta}{9}\right)+\frac{S_{1} S_{2}}{2 \eta m^{4}}\left(\cos \gamma-3 \cos \kappa_{1} \cos \kappa_{2}\right)\right. \\
& \left.\left.+\frac{1}{4} \sum_{i=1}^{2} p_{i}\left(3 \cos ^{2} \kappa_{i}-1\right)+\frac{d_{1} d_{2} \mathcal{A}_{0}}{2 \eta m^{4}}\right]\right\}
\end{aligned}
$$

ahol $\mathcal{A}_{0}=\alpha_{D D}$ a $(\mathbb{B}-66)$ és $(\mathbb{B}-77)$ egyenletekkel definiált mennyiség. A PN rendek az $m \omega$ hatványaival mérhetők, pl. $1 \mathrm{PN}$ rendre $(m \omega)^{2 / 3}$. A (8.6]) és $v=r \omega$ egyenletek felhasználásával az $E(r, v)$ pillanatnyi energia [36] kifejezhető lesz az $\omega$ pályafrekvenciával, vagyis

$$
\begin{aligned}
E(\omega)= & -\frac{1}{2} \mu(m \omega)^{2 / 3}\left\{1-\frac{1}{4}\left(3+\frac{1}{3} \eta\right)(m \omega)^{2 / 3}+m \omega \sum_{i=1}^{2}\left(\frac{8}{3} \frac{m_{i}^{2}}{m^{2}}+2 \eta\right) \frac{S_{i}}{m_{i}^{2}} \cos \kappa_{i}\right. \\
& +(m \omega)^{4 / 3}\left[\frac{1}{8}\left(-27+19 \eta-\frac{1}{3} \eta^{2}\right)+\frac{S_{1} S_{2}}{\eta m^{4}}\left(\cos \gamma-3 \cos \kappa_{1} \cos \kappa_{2}\right)\right. \\
& \left.\left.+\frac{1}{2} \sum_{i=1}^{2} p_{i}\left(3 \cos ^{2} \kappa_{i}-1\right)+\frac{d_{1} d_{2} \mathcal{A}_{0}}{\eta m^{4}}\right]\right\} .
\end{aligned}
$$

A (‥5) szekuláris energiaveszteség, a (‥4) pályafrekvencia-fejlődés és a pályafrekvenciával megadott energia (8.7) egyenletekből kapjuk meg az $\omega$-tól függő pályafrekvencia- 
veszteséget

$$
\begin{aligned}
\frac{d \omega}{d t}= & \frac{96 \eta m^{5 / 3} \omega^{11 / 3}}{5}\left[1-\left(\frac{743}{336}+\frac{11}{4} \eta\right)(m \omega)^{2 / 3}+(4 \pi-\beta) m \omega\right. \\
& \left.+\left(\frac{34103}{18144}+\frac{13661}{2016} \eta+\frac{59}{18} \eta^{2}+\sigma\right)(m \omega)^{4 / 3}\right],
\end{aligned}
$$

ahol

$$
\sigma=\sigma_{S S}+\sigma_{S S-s e l f}+\sigma_{Q M}+\sigma_{D D}
$$

Az egyes szögfüggő $\beta, \sigma_{S S}, \sigma_{S S-s e l f}, \sigma_{Q M}$ és $\sigma_{D D}$ a SO, SS, SS-Self, QM és DD járulékokból ún. spinparaméterek kaphatók, melyek a következőképpen néznek ki

$$
\begin{gathered}
\beta=\frac{1}{12} \sum_{i=1}^{2} \frac{S_{i}}{m_{i}^{2}}\left(113 \frac{m_{i}^{2}}{m^{2}}+75 \eta\right) \cos \kappa_{i}, \\
\sigma_{S S}=\frac{S_{1} S_{2}}{48 \eta m^{4}}\left(-247 \cos \gamma+721 \cos \kappa_{1} \cos \kappa_{2}\right), \\
\sigma_{S S-\text { self }}=\frac{1}{96 m^{2}} \sum_{i=1}^{2}\left(\frac{S_{i}}{m_{i}}\right)^{2}\left(6+\sin ^{2} \kappa_{i}\right), \\
\sigma_{Q M}=-\frac{5}{2} \sum_{i=1}^{2} p_{i}\left(3 \cos ^{2} \kappa_{i}-1\right), \\
\sigma_{D D}=-\frac{5}{\eta m^{4}} d_{1} d_{2} \mathcal{A}_{0} .
\end{gathered}
$$

A newtoni, PN, SO, SS, QM, DD, 2 PN és tail (uszály) járulékokat a (8.8) egyenletben írtam fel, amely a [102], [103], [21], [22] irodalmakban is megtalálható, viszont a (8.T0C) egyenlettel definiált önspin járulékot (SS-self) a pályafrekvencia fejlődésben elsőként adtam meg, mely fontos lehet a spines gravitációs hullámalakokban.

A (8.8) egyenlet közönséges differenciálegyenlet az $\omega$ pályafrekvenciára, melyben az összes (8.T0-10.10) spinparaméter állandónak tekinthető, mivel változásuk csak 3 PN rendben jelentkezik (a spinparaméterekben szereplő $\kappa_{i}, \gamma, \alpha_{i}$ és $\beta_{i}$ szögek vezetörendü változása $\varepsilon$-rendü [92]). Ezért a (8.8) egyenlet időben kiintegrálható, melynek invertálásával megkapható a pályafrekvencia időfüggése, vagyis az alábbi

$$
\begin{aligned}
\omega(t)= & \frac{\tau^{-3 / 8}}{8 m}\left\{1+\left(\frac{743}{2688}+\frac{11}{32} \eta\right) \tau^{-1 / 4}+\frac{3}{10}\left(\frac{\beta}{4}-\pi\right) \tau^{-3 / 8}\right. \\
& \left.+\left(\frac{1855099}{14450688}+\frac{56975}{258048} \eta+\frac{371}{2048} \eta^{2}-\frac{3 \sigma}{64}\right) \tau^{-1 / 2}\right\}
\end{aligned}
$$


ahol bevezethető a $\tau=\eta\left(t_{c}-t\right) / 5 m$ dimenziómentes időparaméter a [102] alapján, amely a $\left(t_{c}-t\right)$, végső összeolvadásig" (pontosabban a spirálozási korszak végéig, numerikus számolásokban ISCO-ig) eltelt idővel arányos ( $t_{c}$ integrációs állandó).

\subsection{Keringések száma a befelé spirálozási korszakban}

A ( 8.$\rceil])$ egyenlet további integrálásával megkapható a kettős rendszer $\phi$ fázisa $\left(\phi_{c}\right.$ integrációs állandó) $)^{\text {[B] }}$

$$
\phi_{c}-\phi=\frac{5 m}{\eta} \int \omega(\tau) d \tau .
$$

Bevezetem az $\mathcal{N}=\left(\phi_{c}-\phi\right) / \pi$ mennyiséget, amely a spirálozási korszak végéig a kettős rendszer keringéseinek számát adja meg, amely (8.T2) definíció alapján a következőt kaptam

$$
\begin{aligned}
\mathcal{N}= & \frac{1}{\pi \eta}\left\{\tau^{5 / 8}+\left(\frac{3715}{8064}+\frac{55}{96} \eta\right) \tau^{3 / 8}+\frac{3}{4}\left(\frac{\beta}{4}-\pi\right) \tau^{1 / 4}\right. \\
& \left.+\left(\frac{9275495}{14450688}+\frac{284875}{258048} \eta+\frac{1855}{2048} \eta^{2}-\frac{15 \sigma}{64}\right) \tau^{1 / 8}\right\}
\end{aligned}
$$

A [6]. táblázatban numerikus példákat adok a kettős rendszerek $\mathcal{N}$ keringéseinek számára, amelyben felsorolom az $\mathcal{N}$ mennyiségnek az összes általam tanulmányozott járulékát ( $\beta$ és $\sigma$ mennyiségeket szabad paramétereknek tekintem, mivel szögváltozókat tartalmaznak). A példákhoz a klasszikusnak számító Hulse-Taylor (B1913+16) és J0737-3039 ( [114], [105] és [106]) dupla pulzárokat, egy neutroncsillag-fekete lyuk és további különböző méretü fekete lyuk kettősöket ( [107], [108]) használtam.

A következőkben az önspin járulékot vizsgálom meg, melyben a $\sigma_{S S}$ és $\sigma_{S S-\text { self }}$ spinparamétereket hasonlítom össze a J0737-3039A-B kettősre. A spineket a kettős komponenseinek a saját forgási periódusidejéből (amely 22.7ms és 2773.5ms) adom meg $\left(R_{i}=15 \mathrm{~km}\right)$ és a pulzárok spingeometriájának jellemzésére a Jenet-Ransom modellt [10] használom. Ez a modell a pulzár pálya-impulzusmomentuma és spinje közti szögre két tartományt ad meg (․ ábra), nevezetesen a $167^{\circ} \pm 10^{\circ}\left(\mathcal{I}\right.$. eset) és a $90^{\circ} \pm 10^{\circ}$ ( $\mathcal{I}$. eset), melyeket a $\kappa_{1}$ szögre fogok használni. A kettős rendszer másik $\kappa_{2}$ szögére vonatkozó érték meghatározható a spinprecessziós egyenletek numerikus megoldásából, amely hasonló a [II] irodalomban lévő fekete lyuk kettősökre vonatkozó számolásra. Egyes elméletek szerint ( [112], [11:3]) elképzelhetö olyan eset, melyben az egyik pulzár spinje párhuzamos a pálya-impulzusmomentummal, ezért a példában egyszerüsítésként a $\kappa_{2}=0$ értéket rögzítem, amelyből következik, hogy $\gamma=\kappa_{1}$.

\footnotetext{
${ }^{38}$ Más definíciója is létezik a kettősöket jellemző $\phi$ fázisnak spines rendszerekben, amely megtalálható a [10.9] irodalomban.
} 
6. táblázat. A gravitációs hullámok által okozott keringések száma az ISCO-ig. Az első négy eset földi detektorok (LIGO/Virgo), míg az utolsó kettő a LISA detektor érzékelhető frekvencia tartományába esik.

\begin{tabular}{lcccccc}
\hline \hline PN rendek & J0737-3039 & B1913+16 & BDIWW1 & BDIWW2 & BBW1 & BBW2 \\
& $1.337 M_{\odot}$ & $1.387 M_{\odot}$ & $1.4 M_{\odot}$ & $10 M_{\odot}$ & $10^{4} M_{\odot}$ & $10^{7} M_{\odot}$ \\
& $1.250 M_{\odot}$ & $1.441 M_{\odot}$ & $10 M_{\odot}$ & $10 M_{\odot}$ & $10^{5} M_{\odot}$ & $10^{7} M_{\odot}$ \\
\hline \hline$f_{\text {in }}(H z)$ & 10 & 10 & 10 & 10 & $4.199 \times 10^{-4}$ & $1.073 \times 10^{-5}$ \\
$f_{\text {fin }}(H z)$ & 1000 & 1000 & 360 & 190 & $3.997 \times 10^{-2}$ & $2.199 \times 10^{-4}$ \\
\hline $\mathcal{N}_{N}$ & 18310 & 15772 & 3580 & 600 & 21058 & 535 \\
$\mathcal{N}_{P N}$ & 476 & 435 & 212 & 59 & 677 & 55 \\
$\mathcal{N}_{S O}$ & $18 \beta$ & $17 \beta$ & $14 \beta$ & $4 \beta$ & $36 \beta$ & $4 \beta$ \\
$\mathcal{N}_{\sigma}$ & $-2 \sigma$ & $-2 \sigma$ & $-3 \sigma$ & $-\sigma$ & $-5 \sigma$ & $-\sigma$ \\
$\mathcal{N}_{\text {tail }}$ & -208 & -206 & -180 & -51 & -450 & -48 \\
$\mathcal{N}_{2 P N}$ & 10 & 10 & 10 & 4 & 18 & 4 \\
\hline \hline
\end{tabular}

7. táblázat. A J0737-3039A-B kettős pulzárra számolt SO, SS és SS-self spinparaméterek a Jenet-Ransom modell két megoldása alapján.

\begin{tabular}{lll}
\hline \hline spinparaméter & $I$. eset & $I I$. eset \\
\hline$\beta$ & -0.166 & 0.001 \\
$\sigma_{S_{1} S_{2}}\left(10^{-4}\right)$ & -0.372 & 0 \\
$\sigma_{S S-\text { self }}\left(10^{-4}\right)$ & 0.298 & 0.345 \\
\hline \hline
\end{tabular}

Az $\mathcal{I}$. esetben a 7 . táblázat alapján látható, hogy a SO spinparaméternél 4 nagyságreddel kisebb a SS-self és a SS. A (8.10b) és (8.100) definíciókban a numerikus faktorok alapján, a $\sigma_{S S-s e l f}$ és a $\sigma_{S S}$ spinparaméter között két nagyságrendbeli eltérés van, ennek ellenére a numerikus példa eredménye azt mutatja, hogy a $\sigma_{S S-s e l f}$ és a $\sigma_{S S}$ összemérhetők egymással.

A $\mathcal{I} \mathcal{I}$. esetben amikor az egyik spin párhuzamos $\left(\kappa_{1}=0\right)$ és a másik spin merőleges $\left(\kappa_{2}=90^{\circ}\right)$ a pálya-impulzusmomentumra, akkor a SS kölcsönhatás eltűnik $\left(\sigma_{S S}=0\right)$, viszont az önspin lesz járuléka $\left(\sigma_{S S-\text { self }} \neq 0\right)$. Továbbá látható még, hogy a $\sigma_{S S-\text { self }}$ csak 2 nagyságrenddel kisebb a $\beta$ spinparaméternél.

Az önspin járulék fontos a gravitációs hullámok fázisában, ugyanis amikor a kettősnek az egyik spinje elhanyagolható a másikhoz képest, akkor a 2 PN rendü spin-spin kölcsönhatást a SS-self határozza meg, mivel a SS gyakorlatilag zérus. 


\section{Pályafejlődés magasrendü korrekciói}

A mai asztrofizikai mérések alapján a fekete lyukak gyorsan forognak és az emiatt kialakult ún. akkréciós korongból anyag hullik a fekete lyukba. Ezen folyamat következtében a fekete lyuk spinje megnövekszik, amely egy maximális értékig nőhet, valamint a korábbi fejezetekben bevezetett $\tilde{\chi}$ dimenziómentes spinparaméter $\left(\tilde{\chi}=c S / m^{2} G\right)$ maximális értéke 1 lesz. A $\tilde{\chi}$ spinparaméter értéke abban az esetben is nagy, amikor még nincs forgása a fekete lyuknak [14]. Amennyiben az akkréciós korong által emittált fotonok energiáját is figyelembe vesszük a horizonton való behullás után [115], akkor a spinparaméter maximális értéke $\tilde{\chi}=0.9982$. Az asztrofizikai folyamat leírását tovább lehet finomítani az akkréciós korongot övező nyílt és zárt mágneses erővonalak [16], a forgó fekete lyukak körüli mágneses vékony akkréciós korong, valamint a fekete lyukak magnetoszférájában megjelenő jetek segítségével ( [117], [118]). A mérések és a számolások azt mutatják, hogy nem követünk el nagy hibát ha az asztrofizikai fekete lyukakra, vagy galasxismagokra az extrémális Kerr limitet tesszük fel, vagyis a $\tilde{\chi}=1$ értéket, melyet a PN rendbecsléseknél fogok használni.

Az előző fejezetben bemutattam, hogy a befelé spirálozó kettősöket poszt-newtoni technikákkal hogyan lehet leírni a legbelső stabil körpályáig. Ismert, hogy a kettős véges méretéből adódó spinjei és tömeg kvadrupólmomentumai kváziprecessziót végeznek, melyek a (4.73) egyenlet alapján a SO-ra 1.5 PN, míg a SS és QM kölcsönhatásokra 2 PN rendben jelentkeznek a klasszikus mozgáshoz képest. Az ebből adódó szögfejlődés a korábban tárgyalt radiális mozgáshoz képest magasabb rendü, vagyis az (5.40) általános Kepler-egyenlettől függetlenül jelenik meg a kváziprecessziós mozgás. Amennyiben pontosítani akarjuk a leírást, a spinprecessziós egyenletek vizsgálatára van szükség.

A tényleges gravitációs hullámok kimutatása megköveteli a hullámalakok pontos ismeretét, amely meghatározható a forrás és a detektor relatív geometriájából, valamint a forrás pályafejlődéséből. Az utóbbira bevezetett $\phi$ pályafázis (‥2) központi szerepet játszik a gravitációs hullámalakokban, ugyanis lényegesen eltér a különböző rendekig megadott keringések számától a legbelső stabil körpályáig, ezért szükséges magas rendig a $\phi$ fázis ismerete. Ebből adódik, hogy a fizikailag érdekes szituációkban fontos figyelembe venni a spin és a tömeg kvadrupólmomentumból adódó 1.5 PN rendü SO illetve a SS, QM és SS-self $2 \mathrm{PN}$ rendű járulékokat. Ebben a fejezetben is a $G=c=1$ geometriai egységet használom.

\subsection{PN rendek becslése}

A továbbiakban nagyságrendbeli becsléseket fogok végezni a (4.73) spinprecessziós egyenletekben a spin és kvadrupólmomentum járulékokat tartalmazó tagokra (SO, SS 
és QM). A $\nu=m_{2} / m_{1}$ a tömegarányt jelenti, amelyre $m_{2} \leq m_{1}$ konvenciót teszem fel. Ebből látható, hogy ha $\nu \rightarrow 0$, akkor a redukált tömegre $\mu=m_{2}$ adódik. Sok kifejezésben szerepel a szimmetrikus tömegarány $(\eta=\mu / m)$ is (pl. 8.100, 8.100$)$, melyet a $\nu$-vel kifejezeve fogok használni $\eta=\left(2+\nu+\nu^{-1}\right)^{-1}$ (kicsi tömegarányra $\eta \rightarrow \nu$, illetve egyenlö tömegekre $\eta=1 / 4)$.

A szupermasszív fekete lyuk kettősökre a következő fontos paramétereket és rendbecsléseket fogom használni (bevezetni) az egyes kifejezésekben:

1. A PN paraméter: $\varepsilon=m / r \approx v^{2}$.

2. A tömegarány: $\nu=m_{2} / m_{1}$.

3. A maximális forgás: $\tilde{\chi}_{i} \approx 1$, vagyis $S_{i} \approx m_{i}^{2}$.

4. A kompaktság: $R_{i} \approx m_{i}$, vagyis $V_{1} \approx V_{2} \approx 1^{139}$.

Az előző rendbecslések alapján a (4.73) spinprecessziós egyenletekben szereplő SO, SS és QM járulékok együtthatói megbecsülhetők a következőképpen

$$
\begin{aligned}
\frac{S_{2}}{S_{1}} \approx\left(\frac{m_{2}}{m_{1}}\right)^{2}=\nu^{2}, \\
\frac{S_{2}}{L} \approx \frac{m_{2}^{2} V_{2}}{\mu r v}=\left(\frac{m}{r}\right)\left(\frac{1}{v}\right) V_{2} \frac{m_{2}}{m_{1}} \approx \varepsilon^{1 / 2} \nu, \\
\frac{S_{1}}{L}=\frac{S_{2}}{L} \frac{S_{1}}{S_{2}} \approx \varepsilon^{1 / 2} \nu^{-1}, \\
p_{1} \approx-(1+\nu)^{-2}, \\
p_{2} \approx-\left(1+\nu^{-1}\right)^{-2},
\end{aligned}
$$

ahol a $p_{i}=-S_{i}^{2} / m_{i}^{2} m^{2}$ a QM tagokban korábban bevezetett mennyiség.

A galaxisok eloszlásából egy tipikus tömegarány-tartomány kapható, amely $\nu=$ 1/30..1/3 [84] értékkel egyenlő. Így, a legtipikusabb tömegarányra a $\nu=10^{-1}$ értéket fogom használni a továbbiakban, amely lényegesen egyszerüsíti a számolásokat.

\subsection{A gravitációs hullámok $3.5 \mathrm{PN}$ rendig}

A gravitációs hullámok fázisát korábban $2 \mathrm{PN}$ rendig mutattam be, melyet manapság már 3.5 PN rendig ismerünk ( [119], [39], [120]), amely alapján az $\mathcal{N}$ keringések száma a

\footnotetext{
${ }^{39} \mathrm{~A}$ kompaktság miatt az egyes fekete lyukak $R_{i}$ karakterisztikus sugarai összemérhetők a tömegükkel így $R_{i} \approx m_{i}$ és a maximális forgás miatt a kerületi sebességekre a $V_{1} \approx V_{2} \approx 1$ közelítés használható.
} 
spirálozási korszak végéig a következőképpen írható fel formálisan

$$
\begin{aligned}
\mathcal{N}= & \frac{1}{\pi \eta}\left\{\tau^{5 / 8}+1 P N \tau^{3 / 8}+\left(\frac{3 \beta}{16}+\text { tail }^{1.5}\right) \tau^{1 / 4}\right. \\
& +\left(2 P N-\frac{15 \sigma}{64}\right) \tau^{1 / 8}+\left(2.5 P N+\text { tail }^{2.5}+\beta_{P N}\right) \ln \tau \\
& \left.+\left(3 P N+\text { tail }^{3}\right) \tau^{-1 / 8}+\left(3.5 P N+\text { tail }^{3.5}\right) \tau^{-1 / 4}\right\}
\end{aligned}
$$

ahol a $\tau=\eta\left(t_{c}-t\right) / 5 m$ az előző fejezetben is használt dimenziómentes időparamétert jelöli. A $\beta 1.5 \mathrm{PN}$ rendü SO, a $\sigma 2 \mathrm{PN}$ rendü SS, QM és DD járulékokat tartalmaz (区.9)-(8.10日), illetve a $\beta_{P N}$ a SO kölcsönhatás következő rendü korrekciója, amely 2.5 PN rendü (a definíció megtalálható a $C$ függelékben). Az ,nPN" jelölés a tisztán PN rendű korrekciókat, a tail ${ }^{N}$ pedig a PN rendekben megjelenő ,,uszály” korrekciókat jelölik, melyek pontos alakjai megtalálhatók a $C$ függelékben. A tail ${ }^{1.5}$ a korábban is tárgyalt vezetőrendü (1.5 PN) uszálytag, melynek magasabb járulékai is megjelennek a $2.5 \mathrm{PN}$ és 3.5 PN rendekben ( tail $^{2.5}$ és tail ${ }^{3.5}$ ), a gravitációs hullámok nemlinearitásából adódóan. Emellett fellép még a tail ${ }^{3}$ a 3 PN rendü ún. ,, uszály tag uszály tagja”, amely a gravitációs hullámok önszóródása miatt jön létre.
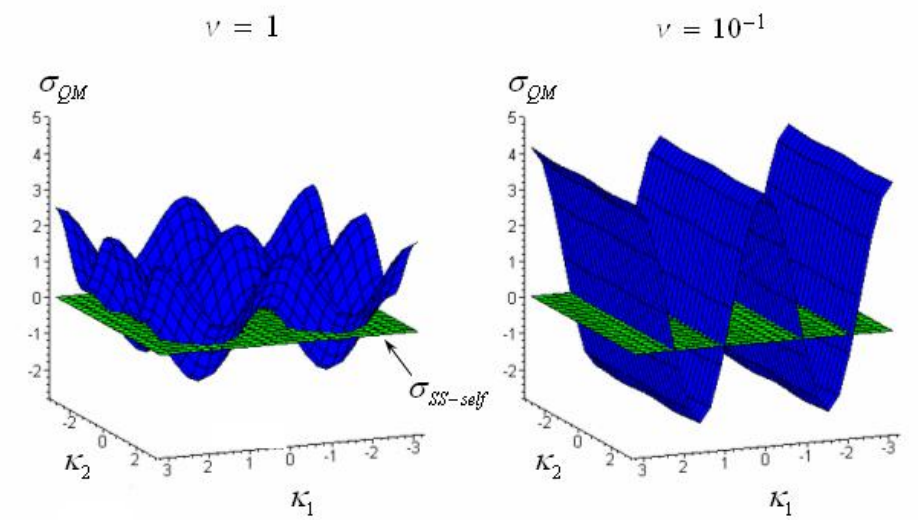

10. ábra. A QM és SS-Self járulék a $\left(\kappa_{1}, \kappa_{2}\right)$ paramétertérben.

A továbbiakban a $\sigma_{S S}$, a $\sigma_{S S-s e l f}$ és a $\sigma_{Q M}$ spinparaméterek szögfüggését vizsgálom egyenlő és nem-egyenlő tömegü esetekben, valamint a $\sigma_{S S}$ vezetőrendű spinprecessziós mozgásból adódó korrekciókat adom meg.

A [.10d ábra a $\sigma_{Q M}$ és $\sigma_{S S-s e l f}$ tagok $\kappa_{i}$ relatív szögeinek függését mutatja egyenlő és nem-egyenlő tömegü ( $\left.\nu=10^{-1}\right)$ esetekre maximális forgás esetén. A két járulék formálisan 2 PN rendü, viszont a numerikus számolásból a $\nu$ tömegaránytól független QM járulék nagyobb, mint a SS-self tag $\left(\sigma_{S S-s e l f} \in(1 / 32,7 / 96) \sum_{i=1,2}\left(m_{i} / m\right)^{2}\right)$. 
Egyenlö tömegü esetben a $\sigma_{S S}$ és ezen keresztül a teljes $\sigma$ a $\left(\kappa_{1}, \kappa_{2}\right)$ paraméter tartományon belül függ a spinek közti (ㅁ. ábra) azimutális $\Delta \psi$ relatív szögtől (ㅁ]. ábra). Az ábrán látható, hogy vannak olyan tartományok, melyeknél ,,kioltás” történik, vagyis a $\sigma_{S S}, \sigma_{S S-s e l f}$ és $\sigma_{Q M}$ összege zérus.
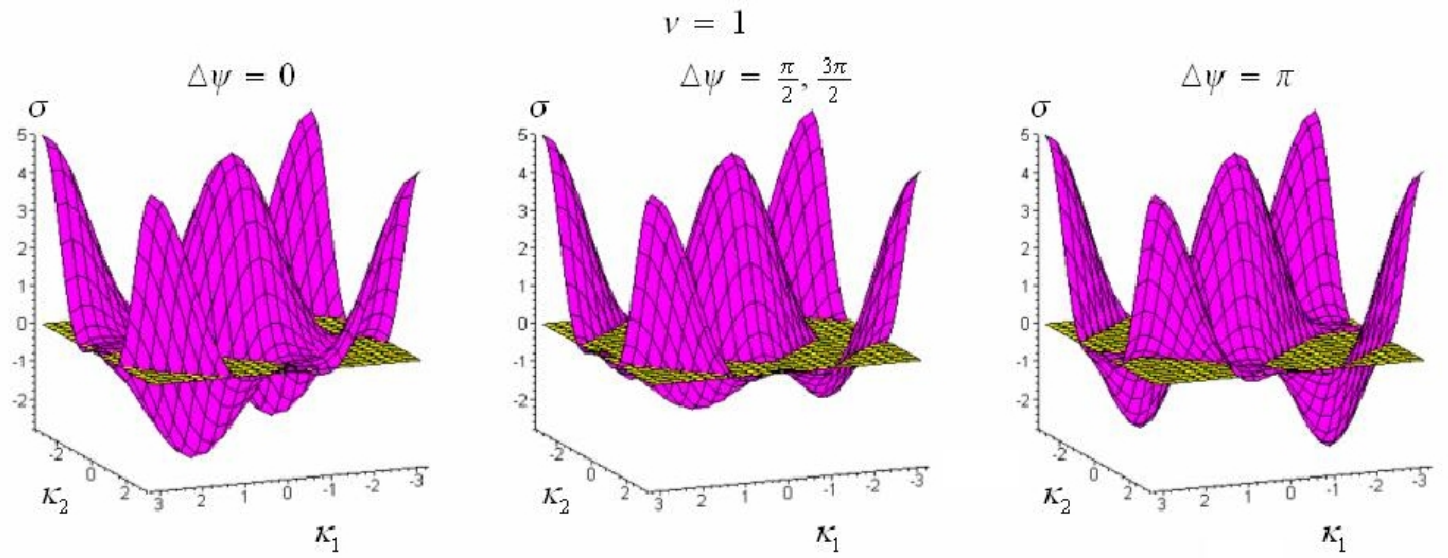

11. ábra. A teljes $\sigma$ spinparaméter egyenlő tömegü $(\nu=1)$ esetben a $\left(\kappa_{1}, \kappa_{2}\right)$ paramétertérben.

Megjegyzendő, hogy a véges méretből származó járulékok a (4.6) keringések számában keveredhetnek egymással például a SO, a SS járulékkal, vagy SO a QM járulékkal, melyek formálisan a 3.5 PN rendben léphetnek fel, ezért fontos meghatározni a gravitációs hullámok fázisában ezen járulékok további rendjeit is.

A továbbiakban a spinprecessziók okozta változásokat mutatom be a SS járulékban, amely egy időfüggést okoz a $\sigma_{S S}$ spinparaméterben, amely $3 \mathrm{PN}$ rendnél jelentkezik.

\subsection{A vezetőrendü spinprecesszióból származó járulék}

A spinvektorok bonyolult kváziprecessziós mozgást végeznek a (4.73) egyenletek alapján. A spinek geometriáját leíró $\cos \kappa_{i}=\left(\hat{\mathbf{L}}_{\mathbf{N}} \cdot \hat{\mathbf{S}}_{\mathbf{i}}\right)$ és $\cos \gamma=\left(\hat{\mathbf{S}}_{\mathbf{1}} \cdot \hat{\mathbf{S}}_{\mathbf{2}}\right)$ relatív szögekre (Z). ábra) meghatározhatóak a fejlődési egyenletek SO, SS és QM járulékok esetén, melyek eddig csak SO és SS esetekben voltak ismertek [92]. Ezek alapján megadtam a QM kölcsönhatásra a $\kappa_{i}$ és $\gamma$ relatív szögek időfejlődését, mely a SO és SS precessziókkal a 
következőképpen írható fel

$$
\begin{aligned}
\left(\cos \kappa_{1}\right)^{\cdot}= & \frac{3 G S_{2}}{c^{2} r^{3}}\left\{\frac{2+\nu^{-1}}{2} \hat{\mathbf{L}}_{N} \cdot\left(\hat{\mathbf{S}}_{\mathbf{1}} \times \hat{\mathbf{S}}_{\mathbf{2}}\right)+\left[\left(\hat{\mathbf{r}} \cdot \hat{\mathbf{S}}_{\mathbf{2}}\right)-\tilde{\gamma}_{1}\left(\hat{\mathbf{r}} \cdot \hat{\mathbf{S}}_{\mathbf{1}}\right)\right] \hat{\mathbf{L}}_{\mathbf{N}} \cdot\left(\hat{\mathbf{r}} \times \hat{\mathbf{S}}_{\mathbf{1}}\right)\right. \\
& \left.+\frac{S_{1}}{L_{N}}\left[\left(\hat{\mathbf{r}} \cdot \hat{\mathbf{S}}_{\mathbf{1}}\right)-\tilde{\gamma}_{2}\left(\hat{\mathbf{r}} \cdot \hat{\mathbf{S}}_{\mathbf{2}}\right)\right] \hat{\mathbf{r}} \cdot\left(\hat{\mathbf{S}}_{\mathbf{1}} \times \hat{\mathbf{S}}_{\mathbf{2}}\right)\right\}, \\
\left(\cos \kappa_{2}\right)^{\cdot}= & \frac{3 G S_{1}}{c^{2} r^{3}}\left\{-\frac{(2+\nu)}{2} \hat{\mathbf{L}}_{\mathbf{N}} \cdot\left(\hat{\mathbf{S}}_{\mathbf{1}} \times \hat{\mathbf{S}}_{\mathbf{2}}\right)+\left[\left(\hat{\mathbf{r}} \cdot \hat{\mathbf{S}}_{\mathbf{1}}\right)-\tilde{\gamma}_{2}\left(\hat{\mathbf{r}} \cdot \hat{\mathbf{S}}_{\mathbf{2}}\right)\right] \hat{\mathbf{L}}_{\mathbf{N}} \cdot\left(\hat{\mathbf{r}} \times \hat{\mathbf{S}}_{\mathbf{2}}\right)\right. \\
(\cos \gamma)^{\bullet}= & \frac{3 G L_{N}}{c^{2} r^{3}}\left\{\frac{S_{2}}{L_{N}}\left[\left(\hat{\mathbf{r}} \cdot \hat{\mathbf{S}}_{\mathbf{2}}\right)-\tilde{\gamma}_{1}\left(\hat{\mathbf{S}}_{\mathbf{1}} \cdot \hat{\mathbf{r}}\right)\right] \hat{\mathbf{r}} \cdot\left(\hat{\mathbf{S}}_{\mathbf{1}} \times \hat{\mathbf{S}}_{\mathbf{2}}\right)\right\},\left(\hat{\mathbf{S}}_{\mathbf{1}} \times \hat{\mathbf{S}}_{\mathbf{2}}\right)+\left[\frac{S_{2}}{L_{N}}\left(1+\tilde{\gamma}_{2} \frac{S_{1}}{S_{2}}\right)\left(\hat{\mathbf{r}} \cdot \hat{\mathbf{S}}_{\mathbf{2}}\right)\right. \\
& \left.\left.-\frac{S_{1}}{L_{N}}\left(1+\tilde{\gamma}_{1} \frac{S_{2}}{S_{1}}\right)\left(\hat{\mathbf{r}} \cdot \hat{\mathbf{S}}_{\mathbf{1}}\right)\right] \hat{\mathbf{r}} \cdot\left(\hat{\mathbf{S}}_{\mathbf{1}} \times \hat{\mathbf{S}}_{\mathbf{2}}\right)\right\}
\end{aligned}
$$

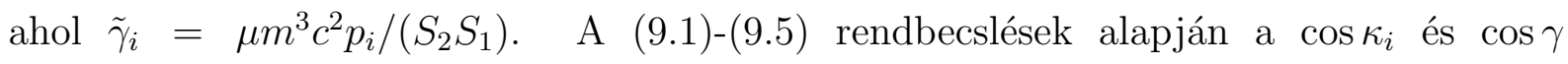
vetezőrendjének változása $\varepsilon^{3 / 2}$ és $\varepsilon$ 四. Így a QM tagok nem változtatnak a rendeken (formálisan ugyanolyan rendűek, mint a SS járulék), vagyis a vezetőrendet a $S O$-precesszió határozza meg (a rendbecslések alapján SS és QM $\varepsilon^{1 / 2}$-el magasabb rendü, mint a SO járulék). Jól látható még, hogy egyenlő tömegű esetben $(\nu=1)$ a $\gamma$ szögre vonatkozó fejlődési egyenlet SO járuléka eltünik (2.7). A továbbiakban csak a SO-precessziót vizsgálom, vagyis a (‥7) egyenletekből a következő írható fel

$$
\begin{aligned}
\left(\cos \kappa_{1}\right)^{\cdot} & =\frac{3 G S_{2}\left(2+\nu^{-1}\right)}{2 c^{2} r^{3}} \hat{\mathbf{L}}_{\mathbf{N}} \cdot\left(\hat{\mathbf{S}}_{\mathbf{1}} \times \hat{\mathbf{S}}_{\mathbf{2}}\right) \\
\left(\cos \kappa_{2}\right)^{\cdot} & =-\frac{3 G S_{1}(2+\nu)}{2 c^{2} r^{3}} \hat{\mathbf{L}}_{\mathbf{N}} \cdot\left(\hat{\mathbf{S}}_{\mathbf{1}} \times \hat{\mathbf{S}}_{\mathbf{2}}\right) \\
(\cos \gamma)^{\bullet} & =\frac{3 G L_{N}\left(\nu-\nu^{-1}\right)}{2 c^{2} r^{3}} \hat{\mathbf{L}}_{\mathbf{N}} \cdot\left(\hat{\mathbf{S}}_{\mathbf{1}} \times \hat{\mathbf{S}}_{\mathbf{2}}\right)
\end{aligned}
$$

A $\kappa_{i}$ és $\gamma$ relatív szögek megváltoztatják a $\beta, \sigma$ és a $\beta_{P N}$ spinparamétereket, a $\sigma_{Q M}$ és $\sigma_{S S-s e l f}$ járulékok (8.10d, 8.10 ) csak $\kappa_{i}$ szöget tartalmaznak és mivel ezen szögek változása

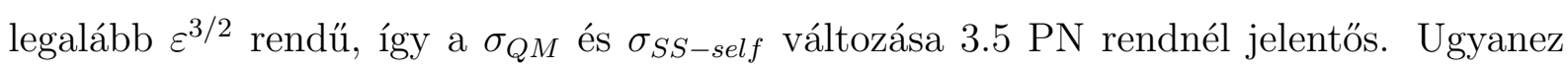
igaz a $\sigma_{S S}$ spinparaméter $\kappa_{i}$ függésére. Ellenben a legalacsonyabb rendü effektust a $\gamma$ szög változása okozza, mivel annak hatása $3 \mathrm{PN}$ rendnél jelentkezik a $\sigma_{S S}$ spinparaméterben. Emiatt a vezetőrendü, vagyis a SO-precesszió miatti változásokat tanulmányozom a $\sigma_{S S}$ paraméterben a (4.8) szerint. Ehhez szükség van a $\gamma$ időfüggésére, melyet a (4.8) egyenlet

\footnotetext{
${ }^{40}$ A szögek infinitezimális változásaira az $O(\delta x)=O(\dot{x}) r \varepsilon^{-1 / 2} / c$ rendbecslést alkalmazom, amely a [9,8] irodalomban található.
} 
alapján a $\Delta \psi$ polárszög ([ா. ábra) segítségével adok meg és a $\kappa_{i}, \Delta \psi=0$ eseteket nem tekintem a továbbiakban megoldásnak

$$
(\cos \gamma)^{\circ}=-\frac{3 L\left(\nu-\nu^{-1}\right)}{2 r^{3}} \sin \kappa_{1} \sin \kappa_{2} \sin \Delta \psi
$$

ahol az $L_{N} \approx L$ közelítést használtam fel ( $L$ megmaradó mennyiség). A gömbi koszinusz azonosság alapján a $\gamma, \kappa_{i}$ és a $\Delta \psi$ szögekre fennáll az alábbi ([. ábra)

$$
\cos \gamma=\cos \kappa_{1} \cos \kappa_{2}+\cos \Delta \psi \sin \kappa_{1} \sin \kappa_{2}
$$

amelyből

$$
\begin{aligned}
\sin \gamma \frac{d \gamma}{d t}= & \sin \kappa_{1} \sin \kappa_{2} \sin \Delta \psi \frac{d}{d t} \Delta \psi \\
& +\cos \Delta \psi\left[\cos \kappa_{1} \frac{d}{d t}\left(\cos \kappa_{2}\right)+\cos \kappa_{2} \frac{d}{d t}\left(\cos \kappa_{1}\right)\right] .
\end{aligned}
$$

A (प.T) egyenlet második tagja elhanyagolható, mivel ezen tagok magasabb rendben jelennek meg $\left(\cos \kappa_{i} \simeq \varepsilon^{3 / 2}\right)$. A (प.g) és (प.T) egyenletek alapján

$$
\frac{d}{d t} \Delta \psi=\frac{3 L_{N}\left(\nu^{-1}-\nu\right)}{2 r^{3}}
$$

Egyenlő tömegü eseteknél látható, hogy a $\Delta \psi$ állandó, vagyis a $\gamma$ szög változatlan lesz a precessziós egyenletek következtében. Így, a $\sigma_{S S}$ spinparamétert tekinthetjük állandónak $3 \mathrm{PN}$ rendig $\nu=1$ esetre. Nem-egyenlö tömegü esetben $(\nu \neq 1)$ a $(\underline{2.12)})$ egyenlet kiintegrálható az előző fejezetekben használt radiális módszerrel. Az integrálást a körpálya határátmenetben számolom $(e=0)$, így $r=a$ és $\dot{\chi}=L / \mu a^{2}$, majd a körpályára érvényes Kepler-egyenletet $\left(n t=\chi, t_{0}=0\right)$ alkalmazva a $\gamma$ szög időfüggésére a (प.T0) egyenlet alapján a következő adódik

$$
\cos \gamma=\cos \kappa_{1} \cos \kappa_{2}+\cos \left[(\Delta \psi)_{0}+\frac{3 \mu n\left(\nu^{-1}-\nu\right)}{2 a} t\right] \sin \kappa_{1} \sin \kappa_{2}
$$

ahol a $(\Delta \psi)_{0}$ jelenti a $t=0$-ban a $\Delta \psi$ azimutális szög kezdeti értékét. A (9.13) egyenlet megadja a $\sigma_{S S}$ spinparaméternek az időfüggő $3 \mathrm{PN}$ járulékát, melynek a $3 \mathrm{PN}$ rendben megjelenő periódusa a következő

$$
T_{3 P N S S}=\frac{2 a}{3 \mu\left(\nu^{-1}-\nu\right)} T
$$

A gravitációs hullám periódusát $\left(T=2 T_{G W}\right)$ bevezetve, és az $\varepsilon \approx m / a$ és $\eta^{-1}=m / \mu=$ $\left(2+\nu+\nu^{-1}\right)$ előző alfejezetben használt rendbecsléseket alkalmazva az alábbit kapjuk a 
periódusidők arányára

$$
\frac{T_{3 P N S S}}{T_{G W}}=\frac{4\left(2+\nu+\nu^{-1}\right)}{3\left(\nu^{-1}-\nu\right) \varepsilon} .
$$
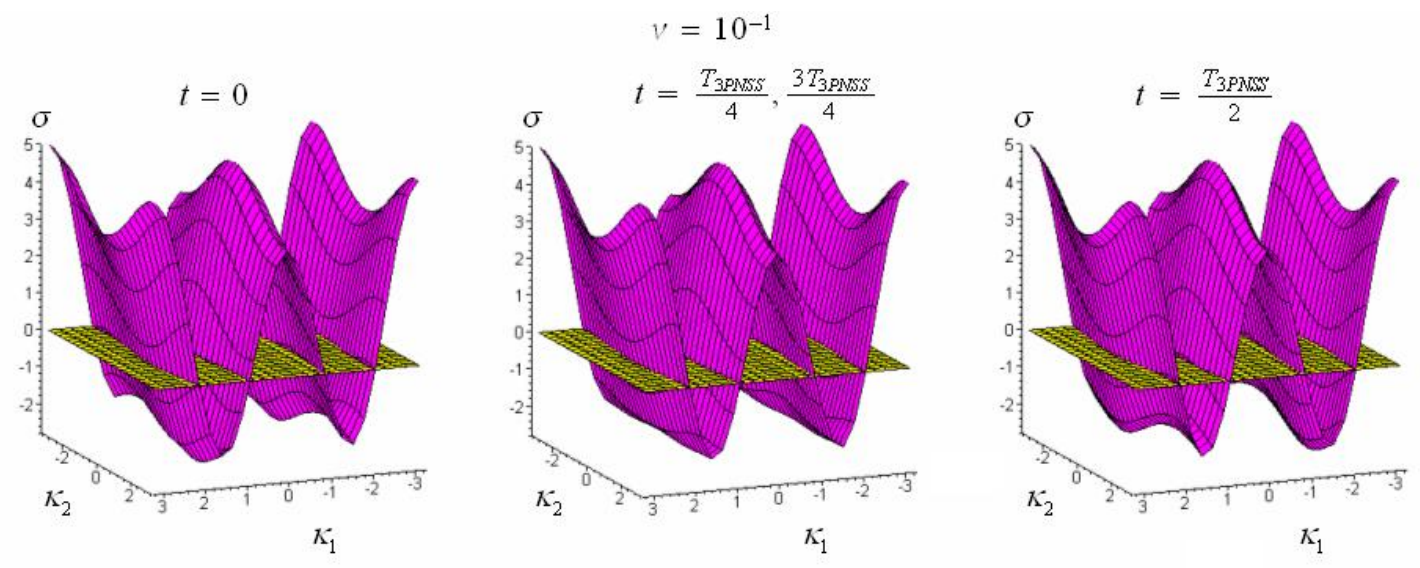

12. ábra. A teljes $\sigma$ spinparaméter nem-egyelő tömegü $\left(\nu=10^{-1}\right)$ esetben a $\left(\kappa_{1}, \kappa_{2}\right)$ paramétertérben.

A $\nu=10^{-1}$ értéket használva a két amplitúdó arányára a $T_{3 P N S S} / T_{G W} \approx 1.63 \varepsilon^{-1}$ mennyiséget kapjuk, amely alapján a $\gamma$ relatív szög változásának periódusideje $\varepsilon^{-1}$ renddel nagyobb, mint a gravitációs hullám periódusideje.

\subsection{Időfejlődés nem-egyenlő tömegekre}

A (9.13) egyenlet alapján a $T_{3 P N S S}$ periódussal vett időskála eltüntethető amennyiben erre átlagolást vezetünk be, amely alapján $\overline{\cos \gamma}=\cos \kappa_{1} \cos \kappa_{2}$. Így bevezethető az áltagolt $\overline{\sigma_{S S}}$, amely a következő

$$
\overline{\sigma_{S S}}=\frac{79 S_{1} S_{2}}{8 \eta m^{4}} \cos \kappa_{1} \cos \kappa_{2}
$$

A továbbiakban a gravitációs hullám fázisában a (9.16) egyenlettel definiált $\overline{\sigma_{S S}}$-t renormált spin-spin paraméternek nevezzük, amely egyszerúbb alakú, mint a korábban használt $\sigma_{S S}$ paraméter. A $\sigma_{S S}$ felírható $3 \mathrm{PN}$ rendig érvényes renormált és egy időfüggő tag összegeként $\sigma_{S S}=\overline{\sigma_{S S}}+\delta \sigma$, ahol

$$
\begin{aligned}
\sigma_{S S} & =\overline{\sigma_{S S}}+\delta \sigma \\
\delta \sigma & =-\frac{247 S_{1} S_{2}}{48 \eta m^{4}} \sin \kappa_{1} \sin \kappa_{2} \cos \left[(\Delta \psi)_{0}+\frac{3 \mu n\left(\nu^{-1}-\nu\right)}{2 a} t\right] .
\end{aligned}
$$

A [2. ábrán látható a teljes $\sigma$ paraméternek az időfüggése $\nu=10^{-1}$ tömegarányra, $T_{3 P N S S}$ negyed periódusaira, melyet a (9.T7) $\sigma_{S S}$ időfüggése okoz. Továbbá látható még a Ш2. ábrán, hogy nem-egyenlő tömegü esetben fóként a QM-ből adódó járulék határozza meg a teljes $\sigma$ spinparamétert. 


\subsection{Keringések száma a spirálozási korszakban spinek jelenlétében}

Az előző fejezetben megmutattam a kettős rendszer gravitációs sugárzása által okozott keringések $\mathcal{N}$ számának ([.T3) származtatását 2 PN rendig, ahol az $\dot{\omega}$ egyenlet integrálásánál a $\sigma_{S S}$ paraméter állandó volt [3.9]. A SO precesszió használata esetén a $\sigma_{S S}$ nem állandó, vagyis az előző egyszerűsítéshez képest pontosabb számolás, ha a $\sigma_{S S}$ változását az $\dot{\omega}$ egyenletben vesszük figyelembe. A továbbiakban az egzakt, illetve az előző alfejezetben használt eredményeket hasonlítom össze a SS spinparaméterekre.

$\mathrm{Az}$ egzakt időben való integrálás során a megoldás nem adható meg elemi függvényekkel, így numerikus integrálással adom meg konkrét esetekre az $\mathcal{N}$ keringések számát. Az előző fejezetben található (․8) egyenletbe behelyettesítve a (4.17) $\sigma_{S S}$ spinparaméter időfüggő részét, valamint a newtoni és a SS tagokat megtartva a következő írható fel

$$
\frac{d(m \omega)}{d \tau}=-96(m \omega)^{11 / 3}-96(m \omega)^{5} \delta \sigma,
$$

(ahol a $\tau=\eta\left(t_{c}-t\right) / 5 m$ a dimenziómentes paraméter) melynek perturbatív megoldását a következő alakban keressük $k^{\text {W1 }}$

$$
m \omega(\tau)=\frac{\tau^{-3 / 8}}{8}+m \omega_{\delta \sigma}(\tau)
$$

A pályafrekvenciát idő szerint integrálva megkapjuk a fázist, vagyis az $\mathcal{N}$ keringések számát a spirálozási korszak végéig

$$
\mathcal{N}=\mathcal{N}_{N}+\mathcal{N}_{\delta \sigma}=\frac{1}{\pi} \int_{\omega_{i}}^{\omega_{f}} \frac{\omega}{\dot{\omega}} d \omega
$$

ahol $\dot{\omega}$-t a (4.19) egyenlet adja meg. A $\delta \sigma(\omega)$ járulékra a (4.]8) egyenletet és a Kepler 3. törvényét $\left(\omega^{2} a^{3}=m\right)$ alkalmazva a (9.14) periódusidő a következő lesz

$$
T_{3 P N S S}=\frac{4 \pi m}{3 \eta\left(\nu^{-1}-\nu\right)(m \omega)^{5 / 3}} .
$$

Az időfüggése az $\omega$ pályafrekvencia vezetőrendjének a (9.20) egyenlet alapján az alábbi

$$
t-t_{c}=-\frac{5 m}{2^{8} \eta}(m \omega)^{-8 / 3}
$$

\footnotetext{
${ }^{41}$ Megjegyzendő, hogy az így figyelembevett eset nem a teljes leírás, hiszen a precessziós egyenleteknek csak a vezetőrendủ (SO-precesszió) járulékát használtuk.
} 
8. táblázat. A kettős rendszer $\mathcal{N}$ keringéseinek száma newtoni, PN, QM és SS járulékokra 3 LISA forrás esetén. A SS járulékoknál megtalálható az előző fejezetben használt $\sigma_{S S}$, a renormált spinparaméter $\bar{\sigma}_{S S}$ és a numerikus integrálásból kapható $\bar{\sigma}_{S S}+\delta \sigma_{S S}(t)$ járulék.

\begin{tabular}{lccc}
\hline \hline$(\Delta \psi)_{0}=15^{\circ}$ & $1.4 M_{\odot}$ & $10^{4} M_{\odot}$ & $10^{6} M_{\odot}$ \\
$\kappa_{1}=\kappa_{2}=30^{\circ}$ & $400 M_{\odot}$ & $10^{5} M_{\odot}$ & $10^{7} M_{\odot}$ \\
\hline \hline$f_{\text {in }}(H z)$ & $4.601 \times 10^{-2}$ & $4.199 \times 10^{-4}$ & $2.361 \times 10^{-5}$ \\
$f_{\text {fin }}(H z)$ & 1.000 & $3.997 \times 10^{-2}$ & $3.997 \times 10^{-4}$ \\
\hline \hline $\mathcal{N}_{N}$ & 2294624.602 & 21055.705 & 1174.257 \\
$\mathcal{N}_{P N}$ & 35363.312 & 677.247 & 114.536 \\
$\mathcal{N}_{\sigma_{Q M}}$ & -432.606 & -13.712 & -6.028 \\
$\mathcal{N}_{\sigma_{S S}}$ & -2.986 & -2.678 & -1.177 \\
$\mathcal{N}_{\bar{\sigma}_{S S}}$ & -3.588 & -3.218 & -1.415 \\
$\mathcal{N}_{\bar{\sigma}_{S S}+\delta \sigma_{S S}(t)}$ & -3.588 & -3.207 & -1.404 \\
\hline \hline
\end{tabular}

Így a (2.18) $\delta \sigma(\omega)$ járulékra a következő adódik

$$
\begin{aligned}
\delta \sigma= & -\frac{247 S_{1} S_{2}}{48 \eta m^{4}} \sin \kappa_{1} \sin \kappa_{2} \\
& \times \cos \left((\Delta \psi)_{0}+\frac{3 \eta\left(\nu^{-1}-\nu\right) t_{c}}{2 m}(m \omega)^{5 / 3}-\frac{15\left(\nu^{-1}-\nu\right)}{2^{9}}(m \omega)^{-1}\right) .
\end{aligned}
$$

A (9.24)-el megadott $\delta \sigma$ járulékot behelyettesítve a (9.19) egyenletbe, megkapjuk az $\mathcal{N}_{\delta \sigma}$ keringések számát, melyeket a korábban számolt $\mathcal{N}_{\sigma_{s s}}$ és $\mathcal{N}_{\bar{\sigma}_{s s}}$ mennyiségekkel hasonlítok össze (《). táblázat).

A numerikus példákhoz 3 nem-egyenlő tömegü LISA forrást használtam, melyeket a [1108] irodalomból vettem. A 8. táblázatban a SS járulékok $\kappa_{i}$ szögeinek változásától függően három különböző eset található, nevezetesen az előző fejezetben használt $\sigma_{S S}$ ( [39]), a renormált $\overline{\sigma_{S S}}$ és a numerikus integrálásból kapható $\delta \sigma$ spinparaméterek. Megadtam a newtoni, PN és QM járulékokat is a nagyságrendek érzékeltetése miatt a 6. táblázathoz hasonlóan. Az $\mathcal{N}$ keringési számok mutatják, hogy nem-egyenlő tömegü esetben a QM spinparaméter nagyobb a SS járulékoknál és a renormált spin-spin járulék értéke megközelíti a numerikus integrálásból kapott értéket.

A teljes 2 PN rendü $\sigma$ paraméter helyett megadhatjuk a renormált spin-spin járulékot tartalmazó teljes $\sigma$-t a QM és SS-self tag összegeként nem-egyenlő tömegekre maximális forgást feltételezve. Tehát a teljes renormált spinparaméter $\bar{\sigma}=\sigma_{Q M}+\overline{\sigma_{S S}}+\sigma_{S S-s e l f}$ értéke a következő lesz

$$
\bar{\sigma} \approx \frac{5}{2}\left[3 \cos ^{2} \kappa_{1}-1+\nu\left(2+\frac{79}{20} \cos \kappa_{1} \cos \kappa_{2}-6 \cos ^{2} \kappa_{1}\right)\right] .
$$


A renormált $\bar{\sigma} 3 \mathrm{PN}$ rendig állandó, míg a $\sigma$ csak 2 PN rendig az. A numerikus példák alapján látható (8. táblázat), hogy a $\bar{\sigma}_{S S}$ renormált járulék 0.02 értékkel, a $\sigma_{S S}$ pedig csak 0.4..0.6 értékkel közelíti meg a numerikus integrálásból kapott értéket a keringési számokban.

A befelé spirálozó galaktikus fekete lyukak elemzéseiből megállapítható, hogy a gravitációs hullámok frekvenciájának és fázisának számolásához figyelembe kell venni az egyes testek $S_{i}$ forgását és a $\nu$ tömegarányt [132]. 


\section{Összefoglalás}

A dolgozat a kompakt kettős rendszerek klasszikus mozgását, valamint a gravitációs sugárzás okozta fejlődését a poszt-newtoni formalizmus segítségével hivatott bemutatni. A bevezetés részben (beleértve a 3 . és 4 . fejezetet) áttekintettem tömören a poszt-newtoni sorfejtés és a gravitációs hullámok alapjait. A mozgásegyenletekben a forgás bevezetését didaktikai szempontból különös gonddal tárgyaltam, melyek kevés irodalomban szerepelnek ilyen részletes leírásban. A további fejezetekben (4.-9.) az új eredményeimet mutattam be, melyeket kellő részletességgel és fontos kiegészítésekkel írtam le.

Megvizsgáltam a kéttest-probléma lineáris perturbációit, nevezetesen az első posztnewtoni rendü tisztán relativisztikus korrekciót, a SO, SS, QM és DD kölcsönhatásokat. Felírtam ezen járulékok Lagrange-formalizmusának segítségével a radiális egyenleteket, majd a lineáris perturbációszámítás segítségével megadtam a radiális mozgás időfejlődését, vagyis az égi mechanikában ismert Kepler-egyenlet általánosítását. A spin-pálya kölcsönhatás Lagrange-függvényét az SSC II mértékben elsőként írtam fel, amely lényegesen egyszerűbb alakú, mint a többi mértékekben (SSC I, SSC III). Az így előállt dinamikát összehasonlítottam az irodalomban használt hamiltoni formalizmusból származtatott SO eredményekkel, amelyek megegyeztek. Megadtam továbbá a Damour és Deruelle által használt parametrizáció [17] és az általánosított valódi anomália paraméterezés közti transzformációt [II].

Tanulmányoztam az általánosan perturbált radiális Kepler-mozgást, melyben a korábban tárgyalt állandó együtthatójú lineáris perturbációk helyett megengedtem a korrekciók valódi anomáliától való harmonikus függését. Az ilyen jellegü radiális perturbációkban legtöbbször szekuláris tagokat kapunk, melyek az általánosított valódi és excentrikus anomália használatával megadhatóak. A radiális egyenlet integrálásánál az $I(\omega, n)=\int \omega / r^{2+n} d t$ alakú integrálok jelennek meg. Az $n$ egész számtól függően a valódi, illetve az excentrikus anomália paraméterezés használata bizonyult megfelelőnek. Ezen paraméterezés bevezetésével szinguláris tagokat kaptam, melyekre megmutattam, hogy eltűntethetőek, amennyiben az általam felírt perturbációs függvény koefficienseire megkövetelt feltételek teljesülnek. A komplex változók bevezetésével a reziduum-tétel használható, mellyel az $I(\omega, n)$ integrálok könnyen kiértékelhetők. Bebizonyítottam a radiális egyenletben szereplő perturbációk egy szélesebb osztályára (ahol $\omega$ tetszőleges harmonikus függvénye lehet a valódi anomáliának), hogy $n \geq 0$ esetén az $I(\omega, n)$ integrál értéke megegyezik az origóban felvett reziduumal, míg $n<0$ esetben az $I(\omega, n)$ 
az origóban és egy $w_{1}$ második pólusban felvett reziduum összegével. A korábban vizsgált SO, SS, QM és DD kölcsönhatásokra felírtam az itt használt perturbációs koefficienseket, majd megmutattam, hogy ezen fizikailag releváns esetekre teljesül az általam kiterjesztett leírás [III].

Tanulmányoztam a vezetőrendü $\mathrm{PN}$ és SO járulékok szögmozgásra gyakorolt hatását. A pálya-impulzusmomentum nagysága állandó a dinamika során, ezt felhasználva kiszámoltam az Euler-szögekre vonatkozó fejlődési egyenleteket úgy, hogy a mozgásállandók meghatározására a Lagrange-formalizmust használtam, majd ezek segítségével felírtam a gömbi polárszögek időfejlődését a $\mathbf{J}=\mathbf{L}+\mathbf{S}$ teljes impulzusmomentum-vektorhoz rögzített inerciális rendszerben. Ezek után a polárszögekkel megadott szögmozgást felírtam az Euler-szögek segítségével és megadtam a szögegyenletek pálya periódusára átlagolt (szekuláris) változásait [VI].

A gravitációs hullámok alakját tanulmányoztam a véges méretből származó korrekciók figyelembevételével. Az egy pálya periódusra átlagolt energia- és impulzusmomentumveszteségeket származtattam körpálya esetben. Ezek megegyeztek a pillanatnyi energiaés pálya-impulzusmomentum [36] irodalomban használt Kidder-féle kvázikörpályából kapott kifejezéseivel. Körpálya esetben felírtam a gravitációs hullámok frekvenciáját és fázisát. Az irodalomban elsőként írtam fel a fázisfüggvényben az ún. önspin kölcsönhatást, melyet korábban nem vettek figyelembe. Ismert kettős rendszerekre (Hulse-Taylor és J0737-3039 kettős pulzárokra) alkalmaztam a gravitációs hullámok keringésének számát $(\mathcal{N})$ a spirálozási korszak végéig. Megmutattam a Jenet-Ransom modell [ए10] alapján, hogy az önspin járuléka nagyobb, mint a spin-spin kölcsönhatásból számolt járulék, egy ,,kicsi” és egy ,,nagy” spinnagyságokkal rendelkező rendszerben [I].

Megvizsgáltam a gravitációs hullámok fázisának magasrendü (3 PN) korrekcióit, vagyis a spinprecessziós egyenletek által módosított kettős rendszer $\mathcal{N}$ keringéseinek számát a spirálozási korszak végéig. Elsőként vezettem le a spinprecessziós egyenletek alapján a $\kappa_{i}$, és $\gamma$ spinvektorokat megadó relatív szögek fejlődési egyenleteit a QM kölcsönhatás esetén (SO és SS kölcsönhatásra [92]). Poszt-newtoni rendbecsléseim alapján a spinprecessziós egyenletek vezetőrendje a SO kölcsönhatásból kapható precesszió. Megmutattam, hogy a gravitációs hullám fázisában szereplő SS járulékban a SOprecesszióból kapható időfüggő korrekció a 3 PN rendnél jelentkezik, amely egyenlő tömegü kettősök esetében nem lép fel. Nem-egyenlő tömegü kettősök esetében ezen járulék periodikus lesz a $T_{3 P N S S}$ periódusidőben, amely rendjét tekintve $\varepsilon^{-1}$-el nagyobb, 
mint a gravitációs hullám periódusa $\left(T_{G W}\right)$. Az $m_{2} / m_{1}=10^{-1}$ tömegarányra összegeztem az $\mathcal{N}$ keringések számában lévő SS és QM járulékokat, majd megmutattam, hogy a QM nagyobb, mint a SS valamint a SS járulék csak kicsi modulációt okoz. Bevezettem egy ún. renormált SS spinparamétert 2 PN rendben, amelynek az állandó része a $3 \mathrm{PN}$ rendben okoz változást a $T_{3 P N S S}=\varepsilon^{-1} T_{\text {wave }}$ időskálán, mely lényegesen egyszerübb alakú, mint a SS spinparaméter [IV],[V]. 


\section{Summary}

In this dissertation I described the classical motion and gravitational-wave-induced development of compact binaries by the aid of the post-Newtonian formalism. In the introductory part (including Sections 3 and 4) I gave a brief review of the bases of the postNewtonian expansion and gravitational waves. For didactical reasons I devoted special attention to the introduction of rotation into the equations of motion, which is rarely presented in such detail in the literature. In Sections 4-9 In Sections 4-9 I presented my scientific results in detail together with important supplementary informations and remarks.

I have examined the linear perturbations of the two-body problem, namely, the purely relativistic correction of first post-Newtonian order, the SO, SS, QM and DD interactions. I described the radial equations with the help of the Lagrange formalism of these contributions, then, using linear perturbation theory, I gave the time development of the radial motion, that is, the generalization of Kepler's equation known from celestial mechanics. I was the first to determine the Lagrangian of the spin-orbit interaction in SSC II gauge, which has a substantially simpler form, than in other gauges (SSC I, SSC III). I compared the resulting dynamics with the SO results derived from the Hamilton formalism presented in the literature, and I found the two to be identical. In addition, I determined the transformation between the parametrization used in the Damour-Deruelle formalism [17] and the generalized true anomaly parametrization.

I have studied the generally perturbed radial Kepler motions in which instead of the previously mentioned linear perturbations of constant factor I allowed for the harmonic dependence of the corrections from the true anomaly. In such radial perturbations one mostly obtains secular terms which can be given by using the generalized true and eccentric anomaly. As a result of the integration of the radial equation, $I(\omega, n)=$ $\int \omega / r^{2+n} d t$ shaped integrals appear. Depending on the $n$ integer number either the use of the true or the eccentric anomaly parametrization was proved to be suitable. With the introduction of this parametrization I found singular terms, for which I showed that they can be eliminated if the conditions for the coefficients of my perturbation function are fulfilled. By introducing complex variables the residuum theorem could be applied and the $I(\omega, n)$ integrals could easily be computed. For a wider class of the perturbations in the radial equation I have proved that in case of $n \geq 0$ the value of the $I(\omega, n)$ integral (where $\omega$ is an arbitrary function of the true anomaly) would be equal to the residuum in the origin, while in the case of $n<0$, the value of the $I(\omega, n)$ integral would 
be equal to the sum of the residuum in the origin and the residuum in a second $w_{1}$ pole. For the previously examined SO, SS, QM and DD interactions I gave the described perturbational coefficients, and showed that the formalism I developed is fullfilled for these physically relevant cases [III].

I investigated the effect of the leading-order PN and SO terms on the angular motion. Using the fact that the magnitude of the orbital angular momentum is constant during the dynamics, I gave the time evolution equations of the Euler angles by using the Lagrange formalism to determine the constants of motion, and thereby, I determined the time evolution of spherical polar angles in the inertial frame of the $\mathbf{J}=\mathbf{L}+\mathbf{S}$ total angular momentum. I gave the angular motion in Euler angles and determined its (secular) changes averaged for the orbital period [VI].

I investigated the shape of gravitational waves taking into account the contributions resulting from finite size. I derived the losses of energy and angular momentum averaged over one orbital period for a circular orbit. These were identical to the expressions for the instantaneous energy and angular momentum obtained for the Kidder type of circular orbit [14] used in the literature. In the case of a circular orbit I determined the frequency and phase of gravitational waves. I was the first to give the so-called self-spin interaction in the phase function, which had previously been neglected. For known binary systems (such as the Hulse-Taylor and the J0737-3039 binary) I applied the accumulated number of gravitational wave cycles $(\mathcal{N})$ until the end of the inspiralling period. Based on the Jenet-Ransom model [28] I showed that the term resulting from the self-spin is greater than the one resulting from the spin-spin interaction in a system with 'small' and 'large' spins $[\mathrm{I}]$.

I investigated the high-order (3 PN) corrections to the phase of gravitational waves, i.e., the $\mathcal{N}$ the accumulated number of gravitational wave cycles until the end of the inspiralling period of a binary system modified by the equations of spin precession. Based on the equations of spin precession, I was the first to derive the equations describing the evolution of relative angles determining the $\kappa_{i}$ and $\gamma$ spin vectors in the case of QM interaction (for SO and SS interactions [33]). Based on my post-Newtonian estimations the leading order of the equations of spin precession is the precession resulting from the SO interaction. I showed that in the SS term in the phase of the gravitational wave the time-dependent correction of SO origin develops at the third PN order, which does not appear for binaries of equal mass. In the case of binaries of unequal mass this term is periodic in $T_{3 P N S S}$, which is of order $\varepsilon^{-1}$ greater than the period of the gravitational 
wave $\left(T_{G W}\right)$. For $m_{2} / m_{1}=10^{-1}$ mass ratio I summed up the SS and QM terms in the $\mathcal{N}$ number of revolution and showed that the QM term is larger than the SS term, and the SS term causes only a minor modulation. I introduced the so-called renormalized SS spin parameter in $2 \mathrm{PN}$ order, the constant part of which causes a change in the $3 \mathrm{PN}$ order on the time scale $T_{3 P N S S}=\varepsilon^{-1} T_{\text {wave }}$, which is of a much more simple form, than the SS spin parameter [IV],[V]. 


\section{Publikációs lista}

\section{Felhasznált publikációk}

I B. Mikóczi, M. Vasúth és L. Á. Gergely, Self-interaction spin effects in inspiralling compact binaries, Phys. Rev. D 71, 124043 (2005).

II Z. Keresztes, B. Mikóczi és L. Á. Gergely, Kepler equation for inspiralling compact binaries, Phys. Rev. D 72, 104022 (2005).

III L. Á. Gergely, Z. Keresztes és B. Mikóczi, An Efficient Method for the Evaluation of Secular Effects in the Perturbed Keplerian Motion, Astrophys. J. Suppl. 167, 286 (2006).

IV L. Á. Gergely és B. Mikóczi, Renormalized second post-Newtonian spin contributions to the accumulated orbital phase for LISA sources Phys. Rev. D 79, 064023 (2009).

V L. Á. Gergely, P. L. Biermann, B. Mikóczi és Z. Keresztes, Renormalized spin coefficients in the accumulated orbital phase for unequal mass black hole binaries, Class. Quant. Grav. 26, 204006 (2009).

VI Z. Keresztes, B. Mikóczi, L. Á. Gergely és M. Vasúth Secular momentum transport by gravitational waves from spinning compact binaries, Proceedings of the Eight Edoardo Amaldi Conference on Gravitational Waves (Amaldi8), J. Phys.: Conf. Ser. 228, 012053 (2010).

\section{Egyéb publikációk}

VII M. Vasúth és B. Mikóczi , Self interaction of spins in binary systems, AIP Conference Proceedings 861, 794-798 (2006).

VIII B. Mikóczi , Frequency evolution of the gravitational waves for compact binaries, ASP Conference Series 349, 301-304 (2006).

IX Z. Keresztes és B. Mikóczi, Kepler equation for the compact binaries under the spin-spin interaction, ASP Conference Series 349, 265-268 (2006).

X B. Mikóczi és Z. Keresztes, Generalized eccentric vs. true anomaly parametrizations in the perturbed Keplerian motion, Publications of the Astronomy Department of the Eötvös University (PADEU) 17, 63-69 (2006). 
XI L. Á. Gergely, Z. Keresztes és B. Mikóczi, The second post-Newtonian order generalized Kepler equation, Proceedings of the Eleventh Marcel Grossmann Meeting 2006, Eds. H Kleinert, RT Jantzen and R Ruffini, World Scientific, Singapore, p 2497-2499 (2008).

XII M. Vasúth, B. Mikóczi és L. Á Gergely, Orbital phase in inspiralling compact binaries, Proceedings of the Eleventh Marcel Grossmann Meeting 2006, Eds. H Kleinert, RT Jantzen and R Ruffini, World Scientific, Singapore, p. 2503-2505 (2008).

XIII B. Mikóczi, Elliptic waveforms for inspiralling compact binaries, J. Phys.: Conf. Ser. 218, 012011 (2010).

XIV M. Vasúth, B. Mikóczi, B. Kocsis és P. Forgács, LISA parameter estimation accuracy for compact binaries on eccentric orbits, to be published in MG12 (2010). 


\section{Köszönetnyilvánítás}

Szeretnék köszönetet mondani témavezetőmnek Dr. Gergely Árpád Lászlónak, akitől kezdetben a relativitáselmélet alapjait tanultam, nehéz hangsúlyozni a rengeteg tudást, melyet átadott nekem. Az általa megjelölt témakör a mai asztrofizikának egy intenzíven kutatott része. A dolgozatban szereplő összes új eredményem az ő irányítása és segítsége alatt született. Köszönöm, hogy mindvégig támogatott a tudományos pályámon, illetve köszönöm a precíz és részletes észrevételeit, mellyel folyamatosan segítette a disszertáció elkészülését.

Szeretném megköszönni Keresztes Zoltánnak és Dr. Vasúth Mátyás kollégáimnak a szakmai segítségét, mely nélkül az új tudományos eredmények nem jöhettek volna létre. Illetve külön köszönet még Dr. Vasúth Mátyásnak a dolgozat részletes átnézésében nyújtott szerepéért. Köszönöm P. L. Biermann professzornak, hogy szakmai tudásával segítette az egyik asztrofizikai témakör mélyebb megértését, mely nemrég jelent meg egy folyóiratban.

Köszönöm Dr. Forgács Péternek, hogy támogatott a KFKI Részecske- és Magfizikai Kutatóintézetének (RMKI) Elméleti Fizikai Főosztályára kerülésemben, továbbá köszönöm a szakmai segítségét melyet az RMKI-ban végzett feladataim megoldásához nyújtott, valamint hasznos tanácsait és javaslatait, mellyel a dolgozat megírását is segítette. Köszönöm a KFKI RMKI Elméleti Fizikai Főosztályának, hogy lehetővé tették, hogy fiatal kutatói ösztöndíjban részesüljek.

Köszönöm az OTKA-nak, hogy doktori éveim után és a fiatal kutatói ösztöndíj közötti időben az NI68228 pályázatból finanszírozásban részesülhettem az MTA KFKI RMKI Elméleti Fizikai Főosztályán.

Végül de nem utolsó sorban, ezúton szeretnék köszönetet mondani szüleimnek akik mindvégig támogattak az elképzeléseim megvalósításában.

Illetve köszönettel tartozom Nádas Editnek, Dr. Kálmán Orsolyának és Horváth Zoltánnak, akik éles látásukkal segítették a dolgozat létrejöttét. 


\section{Appendix}

\section{Gyorsulás származtatása a Lagrange-függvényből SSC I és}

\section{SSC II mértékekben}

Az SSC I (Pirani) mértékben a Lagrange-függvény

$$
\mathcal{L}_{N+S O}^{I}=\frac{\mu \mathbf{v}^{2}}{2}+\frac{G m \mu}{r}+\frac{2 G \mu}{c^{2} r^{3}} \mathbf{v} \cdot[\mathbf{r} \times(\mathbf{S}+\boldsymbol{\sigma})]+\frac{\mu}{2 c^{2} m} \mathbf{v} \cdot(\mathbf{a} \times \boldsymbol{\sigma})
$$

Mivel a Lagrange-függvény gyorsulásfüggő, ezért a ,,kiterjesztett” Euler-Lagrangeegyenleteket kell használni

$$
\frac{\partial \mathcal{L}}{\partial \mathbf{r}}-\frac{d}{d t} \frac{\partial \mathcal{L}}{\partial \mathbf{v}}+\frac{d^{2}}{d t^{2}} \frac{\partial \mathcal{L}}{\partial \mathbf{a}}=0
$$

az ebben szereplő mennyiségek

$$
\begin{aligned}
\frac{\partial \mathcal{L}}{\partial \mathbf{r}}= & -\frac{G m \mu}{r^{3}} \mathbf{r}-\frac{6 G \mu}{c^{2} r^{5}} \mathbf{r}(\mathbf{v} \cdot[\mathbf{r} \times(\mathbf{S}+\boldsymbol{\sigma})]) \\
& +\frac{2 G \mu}{c^{2} r^{3}}[(\mathbf{S}+\boldsymbol{\sigma}) \times \mathbf{v}], \\
-\frac{d}{d t} \frac{\partial \mathcal{L}}{\partial \mathbf{v}}= & -\mu \mathbf{a}+\frac{6 G \mu}{c^{2} r^{4}} \dot{r}[\mathbf{r} \times(\mathbf{S}+\boldsymbol{\sigma})]-\frac{2 G \mu}{c^{2} r^{3}}[\mathbf{v} \times(\mathbf{S}+\boldsymbol{\sigma})] \\
& -\frac{3 \mu G \dot{r}}{2 c^{2} r^{4}}[\mathbf{r} \times \boldsymbol{\sigma}]+\frac{\mu G}{2 c^{2} r^{3}}[\mathbf{v} \times \boldsymbol{\sigma}], \\
\frac{d^{2}}{d t^{2}} \frac{\partial \mathcal{L}}{\partial \mathbf{a}}= & \frac{3 G \mu \dot{r}}{2 c^{2} r^{4}}[\boldsymbol{\sigma} \times \mathbf{r}]-\frac{\mu G}{2 c^{2} r^{3}}[\boldsymbol{\sigma} \times \mathbf{v}] .
\end{aligned}
$$


Tehát a Euler-Lagrange egyenletből a gyorsulás kifejezhető

$$
\begin{aligned}
\mu \mathbf{a}= & -\frac{G m \mu}{r^{3}} \mathbf{r}-\frac{6 G \mu}{c^{2} r^{5}} \mathbf{r}(\mathbf{v} \cdot[\mathbf{r} \times(\mathbf{S}+\boldsymbol{\sigma})])+\frac{2 G \mu}{c^{2} r^{3}}[(\mathbf{S}+\boldsymbol{\sigma}) \times \mathbf{v}] \\
& +\frac{6 G \mu}{c^{2} r^{4}} \dot{r}[\mathbf{r} \times(\mathbf{S}+\boldsymbol{\sigma})]-\frac{2 G \mu}{c^{2} r^{3}}[\mathbf{v} \times(\mathbf{S}+\boldsymbol{\sigma})] \\
& -\frac{3 \mu G \dot{r}}{2 c^{2} r^{4}}[\mathbf{r} \times \boldsymbol{\sigma}]+\frac{\mu G}{2 c^{2} r^{3}}[\mathbf{v} \times \boldsymbol{\sigma}] \\
& +\frac{3 G \mu \dot{r}}{2 c^{2} r^{4}}[\boldsymbol{\sigma} \times \mathbf{r}]-\frac{\mu G}{2 c^{2} r^{3}}[\boldsymbol{\sigma} \times \mathbf{v}] \\
= & -\frac{G m \mu}{r^{3}} \mathbf{r}-\frac{6 G \mu}{c^{2} r^{5}} \mathbf{r}(\mathbf{v} \cdot[\mathbf{r} \times(\mathbf{S}+\boldsymbol{\sigma})])+\frac{2 G \mu}{c^{2} r^{3}}[(\mathbf{S}+\boldsymbol{\sigma}) \times \mathbf{v}] \\
& +\frac{6 G \mu}{c^{2} r^{4}} \dot{r}[\mathbf{r} \times(\mathbf{S}+\boldsymbol{\sigma})]-\frac{2 G \mu}{c^{2} r^{3}}[\mathbf{v} \times(\mathbf{S}+\boldsymbol{\sigma})] \\
& -\frac{3 \mu G \dot{r}}{c^{2} r^{4}}[\mathbf{r} \times \boldsymbol{\sigma}]+\frac{\mu G}{c^{2} r^{3}}[\mathbf{v} \times \boldsymbol{\sigma}] \\
= & -\frac{G m \mu}{r^{3}} \mathbf{r}-\frac{6 G \mu}{c^{2} r^{5}} \mathbf{r}(\mathbf{v} \cdot[\mathbf{r} \times(\mathbf{S}+\boldsymbol{\sigma})]) \\
& -\frac{G \mu}{c^{2} r^{3}}[\mathbf{v} \times(4 \mathbf{S}+3 \boldsymbol{\sigma})]+\frac{3 G \mu}{c^{2} r^{4}} \dot{r}[\mathbf{r} \times(2 \mathbf{S}+\boldsymbol{\sigma})]
\end{aligned}
$$

Tehát a gyorsulás

$$
\begin{aligned}
\mathbf{a}_{N+S O}^{I}= & -\frac{G m \mu}{r^{3}} \mathbf{r}+\frac{G}{c^{2} r^{3}}\left\{\frac{6}{r^{2}} \mathbf{r}[(\mathbf{r} \times \mathbf{v}) \cdot(\mathbf{S}+\boldsymbol{\sigma})]\right. \\
& \left.-\mathbf{v} \times(4 \mathbf{S}+3 \boldsymbol{\sigma})+\frac{3 \dot{r}}{r} \mathbf{r} \times(2 \mathbf{S}+\boldsymbol{\sigma})\right\} .
\end{aligned}
$$

Az SSC II (Newton-Wigner-Pryce) mértékben a Lagrange-függvény

$$
\mathcal{L}_{N+S O}^{I I}=\frac{\mu \mathbf{v}^{2}}{2}+\frac{G m \mu}{r}+\frac{G \mu}{2 c^{2} r^{3}} \mathbf{v} \cdot[\mathbf{r} \times(4 \mathbf{S}+3 \boldsymbol{\sigma})]
$$

Az Euler-Lagrange egyenlet

$$
\frac{\partial \mathcal{L}}{\partial \mathbf{r}}-\frac{d}{d t} \frac{\partial \mathcal{L}}{\partial \mathbf{v}}=0
$$

Segédmennyiségek számolása

$$
\begin{aligned}
\frac{\partial \mathcal{L}}{\partial \mathbf{r}}= & -\frac{G m \mu}{r^{3}} \mathbf{r}-\frac{3 G \mu}{2 c^{2} r^{5}} \mathbf{r}(\mathbf{v} \cdot[\mathbf{r} \times(4 \mathbf{S}+3 \boldsymbol{\sigma})]) \\
& +\frac{G \mu}{2 c^{2} r^{3}}[(4 \mathbf{S}+3 \boldsymbol{\sigma}) \times \mathbf{v}], \\
-\frac{d}{d t} \frac{\partial \mathcal{L}}{\partial \mathbf{v}}= & -\mu \mathbf{a}+\frac{3 G \mu}{2 c^{2} r^{4}} \dot{r}[\mathbf{r} \times(4 \mathbf{S}+3 \boldsymbol{\sigma})]-\frac{G \mu}{2 c^{2} r^{3}}[\mathbf{v} \times(4 \mathbf{S}+3 \boldsymbol{\sigma})],
\end{aligned}
$$


tehát

$$
\begin{aligned}
\mu \mathbf{a}= & -\frac{G m \mu}{r^{3}} \mathbf{r}-\frac{3 G \mu}{2 c^{2} r^{5}} \mathbf{r}(\mathbf{v} \cdot[\mathbf{r} \times(4 \mathbf{S}+3 \boldsymbol{\sigma})]) \\
& +\frac{G \mu}{2 c^{2} r^{3}}[(4 \mathbf{S}+3 \boldsymbol{\sigma}) \times \mathbf{v}] \\
& +\frac{3 G \mu}{2 c^{2} r^{4}} \dot{r}[\mathbf{r} \times(4 \mathbf{S}+3 \boldsymbol{\sigma})]-\frac{G \mu}{2 c^{2} r^{3}}[\mathbf{v} \times(4 \mathbf{S}+3 \boldsymbol{\sigma})],
\end{aligned}
$$

A gyorsulás

$$
\begin{aligned}
\mathbf{a}_{N+S O}^{I I}= & -\frac{G m \mu}{r^{3}} \mathbf{r}+\frac{G}{c^{2} r^{3}}\left\{\frac{3}{2 r^{2}} \mathbf{r}[(\mathbf{r} \times \mathbf{v}) \cdot(4 \mathbf{S}+3 \boldsymbol{\sigma})]\right. \\
& \left.-\mathbf{v} \times(4 \mathbf{S}+3 \boldsymbol{\sigma})+\frac{3 \dot{r}}{2 r} \mathbf{r} \times(4 \mathbf{S}+3 \boldsymbol{\sigma})\right\}
\end{aligned}
$$

\section{Radiális egyenlet származtatása SSC I és SSC II mértékekben}

Előállítva a q és p mennyiségeket a $\mathcal{L}_{N+S O}^{I I}$ Lagrange-függvényből

$$
\begin{aligned}
& \mathbf{q}=\frac{\partial \mathcal{L}}{\partial \mathbf{a}}=-\frac{\mu}{2 c^{2} m} \boldsymbol{\sigma} \times \mathbf{v} \\
& \mathbf{p}=\frac{\partial \mathcal{L}}{\partial \mathbf{v}}-\dot{\mathbf{q}}=\mu \mathbf{v}+\frac{2 G \mu}{c^{2} r^{3}}[\mathbf{r} \times(\mathbf{S}+\boldsymbol{\sigma})]
\end{aligned}
$$

ezekből az energiát és pálya-impulzusmomentum vektor meghatározása $(E=\mathbf{p} \cdot \mathbf{v}+\mathbf{q}$. $\mathbf{a}-\mathcal{L}, \mathbf{L}=\mathbf{r} \times \mathbf{p}+\mathbf{v} \times \mathbf{q})$

$$
\begin{aligned}
& E_{S O}^{I I I}=-\frac{G(\mathbf{L} \cdot \boldsymbol{\sigma})}{c^{2} r^{3}}, \\
& \mathbf{L}_{\mathbf{S O}}^{\text {III }}=\frac{\mu}{c^{2} m}\left\{\frac{2 G m}{r^{3}}[\mathbf{r} \times(\mathbf{r} \times(\mathbf{S}+\boldsymbol{\sigma}))]+\frac{1}{2}[\mathbf{v} \times(\mathbf{v} \times \boldsymbol{\sigma})]\right\} .
\end{aligned}
$$


Bevezetve a nulladrendben használt gömbi polárkoordináta-rendszert, felírható a megmaradó energia és pálya-impulzusmomentum nagysága

$$
\begin{aligned}
E= & \frac{\mu}{2}\left[\dot{r}^{2}+r^{2}\left(\dot{\theta}^{2}+\sin ^{2} \theta \dot{\varphi}^{2}\right)\right]-\frac{G m \mu}{r}-\frac{G(\mathbf{L} \cdot \boldsymbol{\sigma})}{c^{2} r^{3}} \\
L^{2}= & \mu(\mathbf{r} \times \mathbf{v})^{2}+\frac{2 \mu}{c^{2} m}\left\{\frac{2 G m}{r^{3}} \mathbf{L} \cdot[\mathbf{r} \times(\mathbf{r} \times(\mathbf{S}+\boldsymbol{\sigma}))]+\frac{1}{2} \mathbf{L} \cdot[\mathbf{v} \times(\mathbf{v} \times \boldsymbol{\sigma})]\right\} \\
= & \mu(\mathbf{r} \times \mathbf{v})^{2}+\frac{2 \mu}{c^{2} m}\left\{\frac{2 G m}{r^{3}} \mathbf{L} \cdot\left[\mathbf{r}(\mathbf{r} \cdot(\mathbf{S}+\boldsymbol{\sigma}))-(\mathbf{S}+\boldsymbol{\sigma}) r^{2}\right]\right. \\
& \left.+\frac{1}{2} \mathbf{L} \cdot\left[\mathbf{v}(\mathbf{v} \cdot \boldsymbol{\sigma})-\boldsymbol{\sigma} v^{2}\right]\right\} \\
= & \mu(\mathbf{r} \times \mathbf{v})^{2}+\frac{2 \mu}{c^{2} m}\left\{-\frac{2 G m}{r}(\mathbf{L} \cdot \mathbf{S})-\left(\frac{1}{2} v^{2}+\frac{2 G m}{r}\right)(\mathbf{L} \cdot \boldsymbol{\sigma})\right\} \\
= & \mu^{2} r^{4}\left(\dot{\theta}^{2}+\sin ^{2} \theta \dot{\varphi}^{2}\right)-2 \frac{G \mu(2 \mathbf{L} \cdot \mathbf{S}+3 \mathbf{L} \cdot \boldsymbol{\sigma})}{c^{2} r}-\frac{4 E(\mathbf{L} \cdot \boldsymbol{\sigma})}{c^{2} m} .
\end{aligned}
$$

ahol felhasználtam a SO tagokban a $v_{N}^{2}=2 E / \mu+2 G m / r$ nulladrendü sebesség kifejezést.

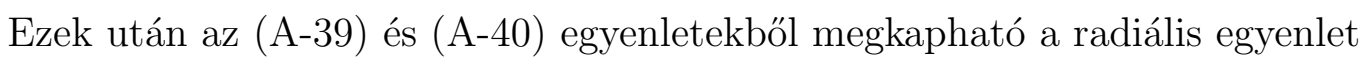

$$
\dot{r}_{I}^{2}=\frac{2 E}{\mu}+\frac{2 G m}{r}-\frac{L^{2}}{\mu^{2} r^{2}}+2 \frac{E(\mathbf{L} \cdot \boldsymbol{\sigma})}{c^{2} m \mu^{2} r^{2}}-\frac{2 G}{c^{2} \mu r^{3}}(2 \mathbf{L} \cdot \mathbf{S}+\mathbf{L} \cdot \boldsymbol{\sigma})
$$

SSC II-ben az energia és az impulzusmomentum lényegesen egyszerűbb alakú alakú, mivel $\mathbf{q}=0$

$$
E=\frac{\partial \mathcal{L}}{\partial \mathbf{v}} \cdot \mathbf{v}-\mathcal{L}, \quad \mathbf{L}=\mathbf{r} \times \frac{\partial \mathcal{L}}{\partial \mathbf{v}}
$$

Tehát a SO korrekciók

$$
\begin{aligned}
& E_{S O}^{I I}=0, \\
& \mathbf{L}_{\text {SO }}^{\text {II }}=\frac{G \mu}{2 c^{2} r^{3}} \mathbf{r} \times[\mathbf{r} \times(4 \mathbf{S}+3 \boldsymbol{\sigma})],
\end{aligned}
$$

hasonlóan mint az SSC I mértéknél polárkoordináták bevezetésével felírható

$$
\begin{aligned}
E & =\frac{\mu}{2}\left[\dot{r}^{2}+r^{2}\left(\dot{\theta}^{2}+\sin ^{2} \theta \dot{\varphi}^{2}\right)\right]-\frac{G m \mu}{r} \\
L^{2} & =\mu^{2} r^{4}\left(\dot{\theta}^{2}+\sin ^{2} \theta \dot{\varphi}^{2}\right)+\frac{G \mu}{c^{2} r^{3}} \mathbf{L}[\mathbf{r} \times[\mathbf{r} \times(4 \mathbf{S}+3 \boldsymbol{\sigma})]] \\
& =\mu^{2} r^{4}\left(\dot{\theta}^{2}+\sin ^{2} \theta \dot{\varphi}^{2}\right)-\frac{G \mu}{c^{2} r}(4 \mathbf{L} \cdot \mathbf{S}+3 \mathbf{L} \cdot \boldsymbol{\sigma})
\end{aligned}
$$

A radiális egyenlet tehát

$$
\dot{r}_{I I}^{2}=\frac{2 E}{\mu}+\frac{2 G m}{r}-\frac{L^{2}}{\mu^{2} r^{2}}-\frac{G(4 \mathbf{L} \cdot \mathbf{S}+3 \mathbf{L} \cdot \boldsymbol{\sigma})}{c^{2} \mu r^{3}}
$$




\section{Transzformáció az SSC I és SSC II mértékek között}

A transzformáció alakja

$$
\begin{aligned}
\mathbf{r}^{I I} & =\mathbf{r}^{I}+\frac{\mathbf{v} \times \boldsymbol{\sigma}}{2 c^{2} m} \\
\mathbf{v}^{I I} & =\mathbf{v}^{I}-\frac{G(\mathbf{r} \times \boldsymbol{\sigma})}{2 c^{2} r^{3}}
\end{aligned}
$$

Az $r$ és $v^{2}$ skalár mennyiségekre az alábbiak adódnak

$$
\begin{aligned}
r^{I I} & =r^{I}+\frac{\mathbf{L} \cdot \boldsymbol{\sigma}}{2 c^{2} m \mu r}, \\
\left(v^{I I}\right)^{2} & =\left(v^{I}\right)^{2}+\frac{G(\mathbf{L} \cdot \boldsymbol{\sigma})}{c^{2} \mu r^{3}} .
\end{aligned}
$$

A pálya-impulzusmomentum transzformációja az SSC I és SSC II között:

$$
\mathbf{L}_{\mathbf{N}}^{I I}=\mathbf{L}_{\mathbf{N}}^{I}-\frac{G \mu}{2 c^{2} r^{3}} \mathbf{r} \times(\mathbf{r} \times \boldsymbol{\sigma})-\frac{\mu}{2 c^{2} m} \mathbf{v} \times(\mathbf{v} \times \boldsymbol{\sigma})
$$

Az $L$ nagyságára

$$
\begin{aligned}
L_{N}^{I I} & =L_{N}^{I}-\frac{G \mu}{2 c^{2} L r^{3}} \mathbf{L}[\mathbf{r} \times(\mathbf{r} \times \boldsymbol{\sigma})]-\frac{\mu}{2 c^{2} m L} \mathbf{L}[\mathbf{v} \times(\mathbf{v} \times \boldsymbol{\sigma})] \\
& =L_{N}^{I}-\frac{G \mu}{2 c^{2} L r^{3}} \mathbf{L}\left[(\mathbf{r} \boldsymbol{\sigma}) \mathbf{r}-r^{2} \boldsymbol{\sigma}\right]-\frac{\mu}{2 c^{2} m L} \mathbf{L}\left[(\mathbf{v} \boldsymbol{\sigma}) \mathbf{v}-\mathbf{v}^{2} \boldsymbol{\sigma}\right] \\
& =L_{N}^{I}+\frac{G \mu}{2 c^{2} L r}(\mathbf{L} \boldsymbol{\sigma})+\frac{1}{c^{2} m L}\left(E+\frac{G m \mu}{r}\right)(\mathbf{L} \boldsymbol{\sigma}) .
\end{aligned}
$$

A pálya-impulzusmomentum vektor

$$
\begin{aligned}
\mathbf{L}= & \mathbf{L}_{\mathbf{N}}^{I}+\mathbf{L}_{\mathbf{S O}}^{I}=\mathbf{L}_{\mathbf{N}}^{I I}+\frac{G \mu}{2 c^{2} r^{3}} \mathbf{r} \times(\mathbf{r} \times \boldsymbol{\sigma})+\frac{\mu}{2 c^{2} m} \mathbf{v} \times(\mathbf{v} \times \boldsymbol{\sigma}) \\
& +\frac{G \mu}{c^{2} r^{3}} \mathbf{r} \times[\mathbf{r} \times(2 \mathbf{S}+\boldsymbol{\sigma})]-\frac{\mu}{2 c^{2} m} \mathbf{v} \times(\mathbf{v} \times \boldsymbol{\sigma}) \\
= & \mathbf{L}_{\mathbf{N}}^{I I}+\frac{G \mu}{2 c^{2} r^{3}} \mathbf{r} \times[\mathbf{r} \times(4 \mathbf{S}+3 \boldsymbol{\sigma})]=\mathbf{L}_{\mathbf{N}}^{I I}+\mathbf{L}_{\mathbf{S O}}^{I I} .
\end{aligned}
$$

Energiára

$$
\begin{aligned}
E^{I} & =\frac{\mu v^{2}}{2}-\frac{G m \mu}{r}+\frac{G(\mathbf{L} \cdot \boldsymbol{\sigma})}{c^{2} r^{3}} \\
& =\frac{\mu\left(v^{I I}\right)^{2}}{2}-\frac{G(\mathbf{L} \cdot \boldsymbol{\sigma})}{2 c^{2} r^{3}}-\frac{G m \mu}{r^{I I}}-\frac{G(\mathbf{L} \cdot \boldsymbol{\sigma})}{2 c^{2} r^{3}}+\frac{G(\mathbf{L} \cdot \boldsymbol{\sigma})}{c^{2} r^{3}}=E^{I I}
\end{aligned}
$$


ahol felhasználtam a transzformációból kapott segédösszefüggéseket

$$
\begin{aligned}
& \left(r^{I I}\right)^{-1}=\left(r^{I}\right)^{-1}-\frac{\mathbf{L} \cdot \boldsymbol{\sigma}}{2 c^{2} m \mu r^{3}}, \\
& \left(r^{I I}\right)^{-3}=\left(r^{I}\right)^{-3}-\frac{3(\mathbf{L} \cdot \boldsymbol{\sigma})}{2 c^{2} m \mu r^{5}} .
\end{aligned}
$$

A (A-46) transzformáció segítségével felírhatók a megmaradó mennyiségek az egyes SSCmértékekben. 


\section{B függelék}

Ez a függelék az 5. fejezethez tartozó összefüggéseket tartalmazza, nevezetesen a radiális mozgás pályaelemeit. A radiális mozgás megadható a következőképpen

$$
\begin{aligned}
r= & a_{r}\left(1-e_{r} \cos \xi\right) \\
\operatorname{vagy} r= & \frac{a_{r}\left(1-e_{r}^{2}\right)}{1+e_{r} \cos \chi} \\
n\left(t-t_{0}\right)= & \xi-e_{t} \sin \xi+f_{t} \sin \left[\chi+2\left(\psi_{0}-\bar{\psi}\right)\right] \\
& +\sum_{i=1}^{2} f_{t}^{i} \sin \left[\chi+2\left(\psi_{0}-\psi_{i}\right)\right]
\end{aligned}
$$

ahol $a_{r}, e_{r}, e_{t}$ és $n$ pályaelemek

$$
\begin{aligned}
a_{r} & =\frac{G m \mu}{-2 E}+a_{r}^{P N}+a_{r}^{S O}+a_{r}^{S S}+a_{r}^{Q M}+a_{r}^{D D}, \\
e_{r} & =\frac{\bar{A}}{G m \mu}+e_{r}^{P N}+e_{r}^{S O}+e_{r}^{S S}+e_{r}^{Q M}+e_{r}^{D D}, \\
e_{t} & =\frac{\bar{A}}{G m \mu}+e_{t}^{P N}+e_{t}^{S O}+e_{t}^{S S}+e_{t}^{Q M}+e_{t}^{D D}, \\
n & =\frac{1}{G m}\left(\frac{-2 E}{\mu}\right)^{3 / 2}\left[1-(\eta-15) \frac{E}{4 c^{2} \mu}\right],
\end{aligned}
$$

valamint az $a_{r}$ fél nagytengely korrekciói

$$
\begin{aligned}
a_{r}^{P N} & =\frac{G m}{4 c^{2}}(\eta-7) \\
a_{r}^{S O} & =\frac{G \mu}{2 c^{2} \bar{L}} \sum_{i=1, j \neq i}^{2} \frac{4 m_{i}+3 m_{j}}{m_{i}} S_{i} \cos \kappa_{i}, \\
a_{r}^{S S} & =-\frac{G \mu S_{1} S_{2}}{2 c^{2} \bar{L}^{2}}\left(\alpha_{S S}+\beta_{S S}\right) \\
a_{r}^{Q M} & =\frac{G m^{3} \mu^{2}}{4 \bar{L}^{2}} \sum_{i=1}^{2} p_{i}\left(\alpha_{Q M}^{i}+\beta_{Q M}^{i}\right), \\
a_{r}^{D D} & =\frac{\mu d_{1} d_{2}}{2 \bar{L}^{2}}\left(\alpha_{D D}+\beta_{D D}\right)
\end{aligned}
$$


az $e_{r}$ radiális excentricitás korrekciói

$$
\begin{aligned}
e_{r}^{P N} & =\frac{E}{4 c^{2} G m \mu^{2} \bar{A}}\left[(5 \eta-15) \bar{A}^{2}-(\eta+9) G^{2} m^{2} \mu^{2}\right] \\
e_{r}^{S O} & =\frac{E\left(G^{2} m^{2} \mu^{2}+\bar{A}^{2}\right)}{c^{2} G m^{2} \mu \overline{L A}} \sum_{i=1, j \neq i}^{2} \frac{4 m_{i}+3 m_{j}}{m_{i}} S_{i} \cos \kappa_{i} \\
e_{r}^{S S} & =-\frac{E S_{1} S_{2}}{c^{2} G m^{2} \mu \bar{L}^{2} \bar{A}}\left[\left(G^{2} m^{2} \mu^{2}+\bar{A}^{2}\right) \alpha_{S S}+\bar{A}^{2} \beta_{S S}\right] \\
e_{r}^{Q M} & =\frac{E m}{2 G \bar{L}^{2} \bar{A}} \sum_{i=1}^{2} p_{i}\left[\left(G^{2} m^{2} \mu^{2}+\bar{A}^{2}\right) \alpha_{Q M}^{i}+\bar{A}^{2} \beta_{Q M}^{i}\right] \\
e_{r}^{D D} & =\frac{E d_{1} d_{2}}{G m \mu \bar{L}^{2} \bar{A}}\left[\left(G^{2} m^{2} \mu^{2}+\bar{A}^{2}\right) \alpha_{D D}+\bar{A}^{2} \beta_{D D}\right]
\end{aligned}
$$

az $e_{t} i d o$-excentricitás korrekció

$$
\begin{aligned}
e_{t}^{P N} & =-\frac{E}{4 c^{2} G m \mu^{2} \bar{A}}\left[(7 \eta-17) \bar{A}^{2}+(\eta+9) G^{2} m^{2} \mu^{2}\right], \\
e_{t}^{S O} & =\frac{E G \mu}{c^{2} \overline{L A}} \sum_{i=1, j \neq i}^{2} \frac{4 m_{i}+3 m_{j}}{m_{i}} S_{i} \cos \kappa_{i}, \\
e_{t}^{S S} & =-\frac{E S_{1} S_{2} G \mu \alpha_{S S}}{c^{2} \bar{L}^{2} \bar{A}}, \\
e_{t}^{Q M} & =\frac{E G m^{3} \mu^{2}}{2 \bar{L}^{2} \bar{A}} \sum_{i=1}^{2} p_{i} \alpha_{Q M}^{i}, \\
e_{t}^{D D} & =\frac{E \mu d_{1} d_{2}}{\bar{L}^{2} \bar{A}} \alpha_{D D},
\end{aligned}
$$

és a 2 PN rendű SS, DD és QM miatt fellépő $f_{t}, f_{t}^{i}$ mennyiségek pedig a következők

$$
\begin{aligned}
f_{t} & =f_{t}^{S S}+f_{t}^{D D} \\
f_{t}^{S S} & =-\left(\frac{-2 E}{\mu}\right)^{3 / 2} \frac{\mu S_{1} S_{2}}{c^{2} m \overline{A L}} \sin \kappa_{1} \sin \kappa_{2}, \\
f_{t}^{D D} & =\left(\frac{-2 E}{\mu}\right)^{3 / 2} \frac{\mu d_{1} d_{2}}{G m \overline{A L}}, \\
f_{t}^{i} & =\left(\frac{-2 E}{\mu}\right)^{3 / 2} \frac{m^{2} \mu^{2}}{2 \overline{A L}} p_{i} \sin ^{2} \kappa_{i} .
\end{aligned}
$$


Az előző kifejezésekben szereplő SS, QM és DD járulékokra bevezetett mennyiségek a következők

$$
\begin{aligned}
\alpha_{S S} & =3 \cos \kappa_{1} \cos \kappa_{2}-\cos \gamma, \\
\beta_{S S} & =\sin \kappa_{1} \sin \kappa_{2} \cos \delta \\
\alpha_{Q M}^{i} & =2-3 \sin ^{2} \kappa_{i}, \\
\beta_{Q M}^{i} & =\sin ^{2} \kappa_{i} \cos \delta_{i}, \\
\alpha_{D D} & =2 \cos \lambda+3\left(\rho_{1} \sigma_{2}-\rho_{2} \sigma_{1}\right) \sin \Delta \psi-3\left(\rho_{1} \rho_{2}+\sigma_{1} \sigma_{2}\right) \cos \Delta \psi, \\
\beta_{D D}(k \chi) & =\left(\sigma_{1} \sigma_{2}-\rho_{1} \rho_{2}\right) \cos [k \chi+\delta]-\left(\rho_{1} \sigma_{2}+\rho_{2} \sigma_{1}\right) \sin [k \chi+\delta], \\
\beta_{D D} & =\beta_{D D}(0),
\end{aligned}
$$

ahol a spinek és dipólmomentumok geometriáját leíró azimutális szögek az alábbiak

$$
\begin{aligned}
\Delta \psi & =\psi_{2}-\psi_{1} \\
\bar{\psi} & =\left(\psi_{1}+\psi_{2}\right) / 2 \\
\delta & =2\left(\psi_{0}-\bar{\psi}\right) \\
\delta_{i} & =\psi_{0}-\psi_{i} \\
\rho_{i} & =\sin \alpha_{i} \cos \beta_{i} \\
\sigma_{i} & =\cos \alpha_{i} \sin \kappa_{i}+\sin \alpha_{i} \sin \beta_{i} \cos \kappa_{i} .
\end{aligned}
$$




\section{C függelék}

Ez a függelék a 9. fejezethez tartozó képleteket tartalmazza.

A gravitációs hullámok által befolyásolt pálya $\mathcal{N}$ keringéseinek száma a kettős spirálozási korszak végéig $\left(\mathcal{N}=\left(\phi_{c}-\phi\right) / \pi\right.$, ahol $\phi_{c}$ az ,,összeolvadás fázisa") a következő alakú ( [119]- [128])

$$
\mathcal{N}=\mathcal{N}_{N}+\mathcal{N}_{1 P N}+\mathcal{N}_{1.5 P N}+\mathcal{N}_{2 P N}+\mathcal{N}_{2.5 P N}+\mathcal{N}_{3 P N}+\mathcal{N}_{3.5 P N}
$$

ahol a PN rendekben megjelenő korrekciók:

$$
\begin{aligned}
\mathcal{N}_{N}= & \frac{1}{\pi \eta} \tau^{5 / 8} \\
\mathcal{N}_{1 P N}= & \frac{1}{\pi \eta}\left(\frac{3715}{8064}+\frac{55}{96} \eta\right) \tau^{3 / 8} \\
\mathcal{N}_{1.5 P N}= & \frac{3}{4 \pi \eta}\left(\frac{1}{4} \beta-\pi\right) \tau^{1 / 4} \\
\mathcal{N}_{2 P N}= & \frac{1}{\pi \eta}\left(\frac{9275495}{14450688}+\frac{284875}{258048} \eta+\frac{1855}{2048} \eta^{2}-\frac{15}{64} \sigma\right) \tau^{1 / 8} \\
\mathcal{N}_{2.5 P N}= & \frac{1}{\pi \eta}\left[\left(-\frac{38645}{172032}+\frac{65}{2048} \eta\right) \pi+\beta_{P N}\right] \ln \tau \\
\mathcal{N}_{3 P N}= & \frac{1}{\pi \eta}\left\{\frac{831032450749357}{57682522275840}-\frac{53}{40} \pi^{2}-\frac{107}{56} C\right. \\
& +\frac{107}{448} \ln \left(\frac{\tau}{256}\right)+\left[-\frac{126510089885}{4161798144}+\frac{2255}{2048} \pi^{2}\right] \eta \\
& \left.+\frac{154565}{1835008} \eta^{2}-\frac{1179625}{1769472} \eta^{3}\right\} \tau^{-1 / 8} \\
\mathcal{N}_{3.5 P N} & \frac{1}{\pi \eta}\left(\frac{188516689}{173408256}+\frac{488825}{516096} \eta-\frac{141769}{516096} \eta^{2}\right) \pi \tau^{-1 / 4}
\end{aligned}
$$

ahol a $\beta, \sigma$ és $\beta_{P N}$ amelyek rendre 1.5 PN, $2 \mathrm{PN}, 2.5 \mathrm{PN}$ spinparaméterek, valamint $\beta$ és

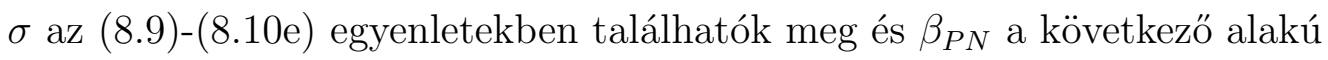

$$
\beta_{P N}=\sum_{i=1}^{2} \frac{S_{i} \cos \kappa_{i}}{m_{i}^{2}}\left[\left(\frac{965}{3584} \eta+\frac{681145}{516096}\right) \frac{m_{i}^{2}}{m^{2}}+\left(\frac{37265}{57344}+\frac{1735}{7168} \eta\right) \eta\right]
$$

ahol $C$ az Euler-Mascheroni állandó $\left(C=\lim _{n \rightarrow \infty}\left[\sum_{k=1}^{n}(1 / k)-\ln n\right] \approx 0.577\right)$. 


\section{Irodalomjegyzék}

[1] A. Einstein, Sitzungsberichte der Königlich Preussischen Akademie der Wissenschaften, 154 (1918).

[2] A. Einstein \& N. Rosen, Journal of the Franklin Institute 223, 43 (1937).

[3] R. A. Hulse \& J. H. Taylor, Astrophys. J. 195, L51 (1975).

[4] J. H. Taylor \& J. M. Weisberg, Astrophys. J. 253, 908s (1982).

[5] R. V. Wagoner, Astrophys. J. 196, 73 (1975).

[6] J. M. Weisberg \& J. H. Taylor, ASP Conf. Ser. 328, 25 (2005).

[7] A. Abramovici et al., Science 256, 325 (1992).

[8] C. Bradaschia et al., Nucl. Instrum. Methods A 289, 518 (1990).

[9] J. Hough, in Proceedings of the Sixth Marcell Grossmann Meeting, edited by H. Sato \& T. Nakamura (World Scientific, Singapore), p. 192 (1992).

[10] K. Kuroda et al., in Proceedings of International Conference on Gravitational Waves: Sources and Detectors, eds. I. Ciufolini \& F. Fidecaro (World Scientific, Singapore), p. 100 (1997).

[11] K. Danzmann, Laser Interferometer Space Antenna: Sixth International LISA Symposium, AIP Conf. Proc. 873 (2006).

[12] F. B. Estabrook \& H. D. Wahlquist, Gen. Rel. Grav. 6, 435 (1975).

[13] P. C. Peters \& J. Mathews, Phys. Rev. 131, 435 (1963).

[14] P. C. Peters, Phys. Rev. 136, 1224 (1964).

[15] A. Einstein, L. Infeld \& B. Hoffmann, Ann. Math. 39, 65 (1938).

[16] L. Infeld \& J. Plebański, Motion and Relativity, Pergamon Press, New York (1960).

[17] T. Damour \& N. Deruelle, Ann. Inst. Henri Poincaré A 43 , 107 (1985).

[18] G. Schäfer \& N. Wex, Phys. Lett. A 174, 196; Err.-ibid. 177, 461 (1993).

[19] R. M. Memmesheimer, A. Gopakumar \& G. Schäfer, Phys. Rev. D 70, 104011 (2004).

[20] L. Kidder, C. Will, \& A. Wiseman, Phys.Rev. D 47, 4183 (1993). 
[21] E. Poisson, Phys. Rev. D 57, 5287 (1998).

[22] K. Ioka \& K. Taniguchi, Astrophys. J. 537, 327 (2000).

[23] M. Mathisson, Acta. Phys. Polon. 6, 167 (1937).

[24] A. Papapetrou, Proc. Phys. Soc. 64, 57 (1951).

[25] F. A. E. Pirani, Acta Phys. Polon. 15, 389 (1956).

[26] W. M. Tulczyjew, Acta Phys. Polon. 18, 393 (1959).

[27] W. Dixon, Nuovo Cim. 34, 317 (1964).

[28] T. D. Newton \& E. P. Wigner, Rev. Mod. Phys. 21, 400 (1949).

[29] M. H. L. Pryce, Proc. Roy. Soc. Lond., A 195, 62 (1948).

[30] E. Corinaldesi \& A. Papapetrou, Proc. Roy. Soc. A 209, 259 (1951).

[31] V. A. Brumberg, Essential Relativistic Celestial Mechanics, Bristol: Adam Hilger, (1991).

[32] M. N. Soffel, Relativity in Astrometry, Celestial Mechanics and Geodesy, Boston: Springer-Verlag, (1988).

[33] L. Á. Gergely, Z. I. Perjés \& M. Vasúth, Astrophys. J. Suppl. 126, 79 (2000).

[34] F. R. Moulton, An introduction to celestial mechanics, New York: The Mac. Comp., Sec. ed. (1914).

[35] Z. Keresztes, B. Mikóczi \& L. Á. Gergely, Phys. Rev. D 71, 124043 (2005).

[36] L. Kidder, Phys. Rev. D 52, 821 (1995).

[37] L. Á. Gergely, Z. Keresztes \& B. Mikóczi, Astrophys. J. Suppl. 167, 286 (2006).

[38] L. Á. Gergely, Phys. Rev. D 62, 024007 (2000).

[39] B. Mikóczi, M. Vasúth, \& L. Á. Gergely, Phys. Rev. D 71, 124043 (2005).

[40] Z. Perjés, Általános relativitáselmélet, Akadémiai kiadó, Budapest (2006).

[41] M. P. Hobson, G. P. Efstathiou \& A. N. Lasenby, General Relativity, CUP, Cambridge (2006).

[42] I. Montvay Relativisztikus kvantummechanika, Tankönyvkiadó, Budapet (1969). 
[43] L. D. Landau \& E. M. Lifsic The Classical Theory of Fields, Pergamon Press (1951).

[44] J. R Oppenheimer \& G. M Volkoff, Phys. Rev. D55, 374 (1939).

[45] R. C. Tolman, Phys. Rev. 55, 364 (1939).

[46] P. Natarajan \& E. Treister, Mon. Not. Roy. Ast. Soc. 393, 838 (2009).

[47] C. W. Misner, K. S. Thorne \& J. A. Wheeler, Gravitation , W. H. Freeman, San Francisco (1973).

[48] A. Vecchio, Phys. Rev. D 70, 042001 (2004).

[49] A. Apostolatos, C. Cutler, G. J. Sussman \& K. S. Thorne, Phys. Rev. D49, 6274 (1994).

[50] C. Cutler, Phys. Rev. D 57, 7089 (1998).

[51] R. N. Lang \& S. A. Hughes, Phys. Rev. D 74, 122001 (2006); Err.-ibid. 75, 089902(E) (2007).

[52] S. M. Kay, Fundamentals of Statistical Signal Processing: Estimation Theory. Prentice Hall. (1993).

[53] L. Barack \& C. Cutler, Phys. Rev. D 69, 082005 (2004).

[54] L. S. Finn, Phys. Rev. D. 46, 5236 (1992).

[55] L. S. Finn \& D. F. Chernoff, Phys. Rev. D 47, 2198 (1993).

[56] M. Trias \& A. M. Sintes, Phys. Rev. D 77, 024030 (2008).

[57] N. Yunes, K. G. Arun, E. Berti \& C. M. Will, Phys. Rev. D 80, 084001 (2009).

[58] K. Yagi \& T. Tanaka, Phys. Rev. D 81, 064008 (2010).

[59] A. Eddington \& G. L. Clark, Proc Roy. Soc. Lon. Ser. A 166, 465 (1938).

[60] H. P. Robertson, Ann. Math. 39, 101 (1939).

[61] S. Weinberg, Gravitation and Cosmology, Wiley, (1972).

[62] T. Damour \& G. Schäfer, Gen. Relativ. Gravit. 17, 879 (1985).

[63] B. Érdi, Égi mechanika, ELTE jegyzet (1989).

[64] L. Infeld \& A. Schild, Rev. Mod. Phys. 21, 408 (1949). 
[65] J. Weyssenhoff \& A. Raabe, Acta. Phys. Polon. 9, 7, (1947).

[66] I. Bailey \& W. Israel, Ann. Phys. (N. Y.) 130, 188 (1980).

[67] J. M. A. Danby, Fundamentals of Celestial Mechanics, 2nd Ed., Willmann-Bell IncRichmond, Virginia (1992).

[68] B. M. Barker \& R. F. O’Connell, Phys. Rev. D 12, 329 (1975).

[69] B. M. Barker \& R. F. O’Connell, Gen. Relativ. Gravit. 5, 539 (1974).

[70] L. I. Schiff, Proc. Natl. Acad. Sci. U. S. 46, 871 (1960).

[71] S. N. Gupta, Proc. Phys. Soc. A 65, 161; A 65, 608 (1952).

[72] S. N. Gupta, Phy. Rev. 96, 1683 (1954).

[73] B. M. Barker, S. N. Gupta \& R. D. Haracz Phys. Rev. 149, 1027 (1966).

[74] Y. Iwasaki, Prog. of Theor. Phys. 46, 1587, (1971).

[75] B. M. Barker \& R. F. O’Connell, Phys. Rev. D 2, 1428 (1970).

[76] R. A. Porto \& I. Z. Rothstein, Phys. Rev. Lett. 97, 021101 (2006).

[77] R. A. Porto \& I. Z. Rothstein, Phys. Rev. D 78, 044012, (2008); Err.-ibid. 81, 029904, (2010).

[78] J. Steinhoff, S. Hergt \& G. Schäfer, Phys. Rev. D 77, 081501 (2008).

[79] G. Börner, J. Ehlers \& E. Rudolph, Astron \& Astophys. 44, 417 (1975).

[80] P. D. D'Eath, Phys. Rev. D 11, 1387; 12, 2183 (1975).

[81] K. S. Thorne \& J. B. Hartle, Phys. Rev. D 31, 1815 (1985).

[82] L. Blanchet, A. Buonanno \& G. Faye, Phys. Rev. D 74, 104034 (2006); Err.-ibid. 75, 049903 (2007).

[83] L. Á. Gergely \& Z. Keresztes, Phys. Rev. D 67, 024020 (2003).

[84] L. Á. Gergely \& P. L. Biermann, Astrophys. J. 697, 1621 (2009).

[85] E. Racine, Phys. Rev. D 78, 044021 (2008).

[86] J. Majár, Phys. Rev. D 80, 104028 (2009).

[87] B. J. Owen, H.Tagoshi \& A.Ohashi, Phys. Rev. D 57, 6168 (1998). 
[88] H. Tagoshi, A. Ohashi \& B. Owen, Phys. Rev. D 63, 044006 (2001).

[89] C. M. Will, Phys. Rev. D 71, 084027 (2005).

[90] H. Wang \& C. M. Will, Phys. Rev. D 75, 064017, (2007).

[91] N. Wex, Class. Quantum Grav 12, 983 (1995).

[92] L. Á. Gergely, Z. I. Perjés \& M. Vasúth, Phys. Rev D 58, 124001 (1998).

[93] M. Vasúth, Z. Keresztes, A. Mihály, \& L. Á. Gergely, Phys. Rev. D 68, 124006 (2003).

[94] R. Rieth \& G. Schäfer, Class. Quantum Grav 14, 2357, (1997).

[95] C. Köenigsdörffer \& A. Gopakumar, Phys. Rev. D71, 024039 (2005).

[96] Z. Keresztes, B. Mikóczi, L. Á. Gergely \& M. Vasúth, J. Phys.: Conf. Ser. 228, 012053 (2010).

[97] L. Blanchet, B. R. Iyer \& B. Joguet, Phys. Rev. D65 064005 (2002); Err.-ibid.

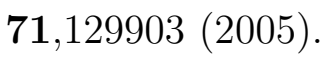

[98] L. Á. Gergely, Phys. Rev. D 61, 024035 (2000).

[99] K. S. Thorne, 300 Years of Gravitation, ed. S. W. Hawking \& W. Israel (Cambridge University Press, Cambridge, England, 1987), p. 330.

[100] A. Gopakumar \& B. R. Iyer Phys. Rev. D 56, 7708, (1997).

[101] L. Blanchet, G. Faye, B. R. Iyer \& B. Joguet, Phys. Rev. D 65, 061501 (2002).

[102] L. Blanchet, Phys. Rev. D 54, 1417 (1996).

[103] E. Poisson \& C. M. Will, Phys. Rev. D 52, 848 (1995).

[104] M. Burgay et al., Nature 426, 531 (2003).

[105] A. G. Lyne et al., Science 303, 1153 (2004).

[106] M. Kramer et al., Science 314, 97 (2006).

[107] L. Blanchet, T. Damour, B. R. Iyer, C. M. Will \& A. G. Wiseman, Phys. Rev. Lett. 74, 3515 (1995).

[108] E. Berti, A. Buonanno \& C. M. Will, Phys. Rev. D 71 , 084025 (2005). 
[109] A. Buonanno, Y. Chen \& M. Vallisneri, Phys. Rev. D 67, 104025 (2003); Err.-ibid. 74, $029904(2006)$.

[110] F. A. Jenet \& S. M. Ransom, Nature 428, 919 (2004).

[111] J. D. Schnittman, Phys. Rev. D 70, 124020 (2004).

[112] V. M. Kaspi et al., Astrophys. J. 613, 137 (2004).

[113] J. Arons, A. Spitkovsky, D. Backer \& V. Kaspi, ASP Conf. Ser. 328, 95 (2005).

[114] J. M. Bardeen, Nature 226, 64 (1970).

[115] D. N. Page \& K. S. Thorne, Astrophys. J. 191, 499 (1974).

[116] R. D. Blandford \& R. L. Znajek, Month. Not. Roy. Astr. Soc. 179, 433 (1977).

D. X. Wang, K. Xiao \& W. H. Lei, Month. Not. Roy. Astr. Soc. 335, 655 (2002).

[117] H. Falcke \& P. L. Biermann, Astron. \& Astroph. 293, 665 (1995).

[118] Z. Kovács, P. L. Biermann \& L. Á. Gergely, Maximal spin and energy conversion efficiency in a symbiotic system of black hole, disk and jet, in preparation arXiv:1007.4279 (2009).

[119] L. Blanchet, G. Faye, B. R. Iyer \& B. Joguet, Phys. Rev. D 65, 061501 (R) (2002); Err.-ibid. 71, 129902 (2005).

[120] A. Buonanno, G. B. Cook \& F. Pretorius, Phys. Rev. D 75, 124018 (2007).

[121] R. V. Wagoner \& C. M. Will, Astrophys. J. 210, 764 (1976); ibid 215, 984 (1977).

[122] L. Blanchet \& T. Damour, Phys. Rev. D 46, 4304 (1992).

[123] E. Poisson, Phys. Rev. D 47, 1497 (1993).

[124] A. G. Wiseman, Phys. Rev. D 48, 4757 (1993).

[125] L. Blanchet \& G. Schäfer, Class. Quantum Grav. 10, 2699 (1993).

[126] L. Blanchet, T. Damour, B. R. Iyer, C. M. Will \& A. G. Wiseman, Phys. Rev. Lett. 74, 3515 (1995).

[127] L. E. Kidder, C. M. Will \& A. G. Wiseman, Phys. Rev. D 47, 3281 (1993).

[128] L. Blanchet, Phys. Rev. D 54, 1417 (1996); Err-ibid. D 71, 129904 (2005). 
[129] L. Blanchet, G. Faye, B. R. Iyer \& S. Sinha, Class. Quantum Grav. 25, 165003 (2008).

[130] E. T. Whittaker \& G. N. Watson, A Course of Modern Analysis, Cambridge:Cambridge Univ. Press (1927).

[131] L. Á. Gergely, P. L. Biermann, B. Mikóczi \& Z. Keresztes, Class. Quant. Grav. 26, 204006 (2009).

[132] L. Á. Gergely \& B. Mikóczi, Phys. Rev. D 79, 064023 (2009). 